\title{
Alien Plant Species Threat Assessment and Management Prioritization for Sequoia-Kings Canyon and Yosemite National Parks
}

By John D. Gerlach, Jr., Peggy E. Moore, Brent Johnson, D. Graham Roy, Patrick Whitmarsh, Daniel M. Lubin, David M. Graber, Sylvia Haultain, Anne Pfaff, and Jon E. Keeley

U.S. GEOLOGICAL SURVEY

Open-File Report 02-170

Carson City, Nevada

2003 


\title{
U.S. DEPARTMENT OF THE INTERIOR GALE NORTON, Secretary
}

\author{
U.S. GEOLOGICAL SURVEY \\ Charles G. Groat, Director
}

The use of firm, trade, and brand names in this report is for identification purposes only and does not constitute endorsement by the U.S Geological Survey.

For additional information, write to:

Center Director

Western Ecological Service Center

U.S. Geological Survey

7801 Folsom Boulevard, Suite 101

Sacramento, CA 95826
Copies of this report can be purchased from:

U.S. Geological Survey

Information Services

Box 25286

Federal Center

Denver, CO 80225 


\section{Executive Summary}

This document reports the results of alien species surveys at Sequoia-Kings Canyon and Yosemite national parks. It includes the findings of a comprehensive literature review of the biology and ecology of all alien plant species found during these surveys and the ranking of those species for prioritizing management and control programs. Surveys primarily targeted areas of human disturbance, such as campgrounds, corrals, developments, roads, trails and pastures. Alien species richness was compared across elevational gradients within the parks. To compare and contrast species composition among sites, an exploratory cluster analysis of the sites included in the speciesrichness-by-elevation figures was conducted using ordination techniques. All alien species discovered during the directed surveys were grouped into one of four management priority categories based on their attributes, potential impacts, and geographical extent (tables 6 and 7). Category 1 species are aliens that are currently restricted to a relatively small number of sites in each park and have either been shown to greatly affect native vegetation or have a high probability of causing serious impacts. Category 2 species are restricted to a relatively small number of sites and are ones that generally have a lesser effect on native vegetation. Category 3 species are broadly distributed in the parks, are apparently increasing their ranges within the parks, and are those that have been shown to have a great impact on native vegetation. Category 4 species are those that were detected by the surveys but not assigned to one of the three ranked categories and are considered low priority.

\section{Acknowledgments}

This project was funded by the U.S. Geological Survey, Weeds of the West Program. Additional funding for field surveys, data management, analysis and report generation on alien plants in Yosemite National Park were provided by the The Yosemite Fund, San Francisco, California (www.yosemitefund.org). The National Park Service was very responsive to surveys reporting satellite populations of highly invasive species. Botanists Justin Adams, Brad Jelinek, Aaron King and Melinda Schroeder provided invaluable field assistance. Judd Howell, Research Manager, USGS, Western Ecological Research Center, assisted in expediting the peer review and publishing of this report. 


\section{Preface}

The introduction and establishment of nonnative plants and animals is a global environmental problem that has steadily worsened over the past few decades. Nowhere is the concern greater than in nature reserves designed to conserve examples of biodiversity and other unique landscape features. The U.S. National Park Service plays an important role as ecological steward over many highly prized and valuable remnants of the natural landscape of the United States. Invasive alien species pose threats to the maintenance of many of these ecosystems, both through their displacement of the native flora and fauna as well as upsetting natural ecosystem processes. Thus, it is vitally important that research be devoted to understanding the threat and means of eliminating these aliens, or in some cases learning how to mitigate their effect. This study is a first attempt at addressing the problem of nonnative plants in Sequoia-Kings Canyon and Yosemite national parks. The focus is on determining the extent and location of alien species, determining which of these pose the greatest threat, and evaluating the extent to which these problems are tractable. While this project focuses on a localized region of the Sierra Nevada Mountain Range of California, it is hoped that this approach may be of broader use in managing alien species problems in other regions as well.

\section{Jon E. Keeley}

U.S. Geological Survey

Biological Resources Discipline

Western Ecological Research Center

Sequoia-Kings Canyon Field Station

Three Rivers, CA 93271

jon_keeley@usgs.gov 


\section{CONTENTS}

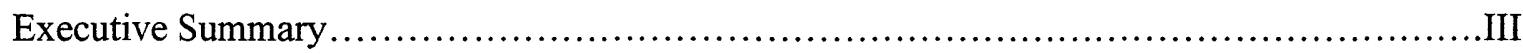

Acknowledgements.......................................................................

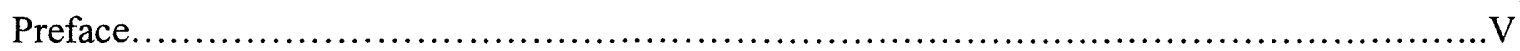

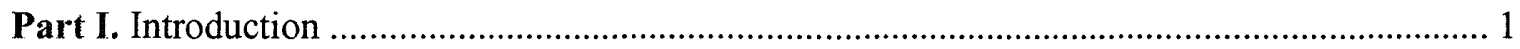

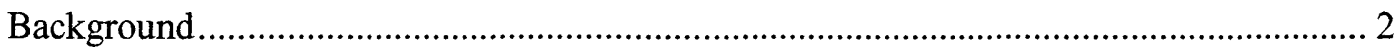

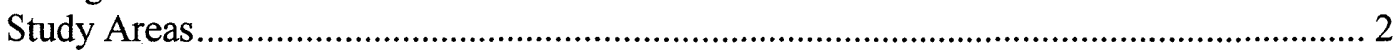

Part II. Directed Survey Results

Sequoia and Kings Canyon National Parks ................................................................. 3

Survey and Quadrat Data Collection ................................................................... 3

Decline of Alien Species Richness with Increasing Elevation ................................. 5

Similarity of Alien Species Composition Among Sites........................................ 10

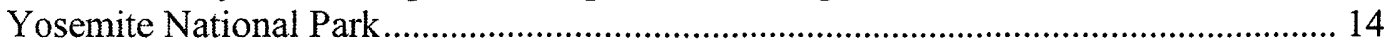

Survey and Quadrat Data Collection .................................................................. 14

General Pattern ................................................................................................... 16

Decline of Alien Species Richness With Increasing Elevation .............................. 16

Similarity of Alien Species Composition Among Sites............................................ 22

Part III. Alien Species Threat Assessment and Prioritization .................................................. 25

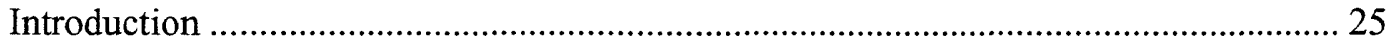

Priority Alien Species Other Than Grasses ………........................................................ 30

Localized Wildland Species with Moderate to High Impact - Category 1 Species... 30

Localized Legumes with Moderate to High Impact - Category 1 Species ................. 34

Localized Fruit and Nut Species with High Impact - Category 1 and 2 Species....... 36

Localized Ornamentals with High Impact - Category 1 Species.............................. 37

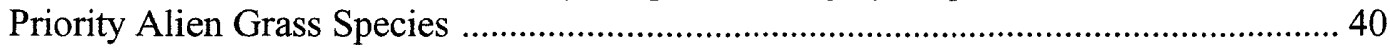

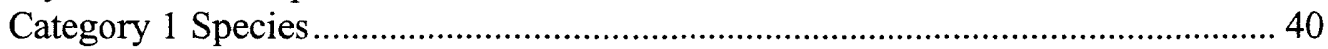

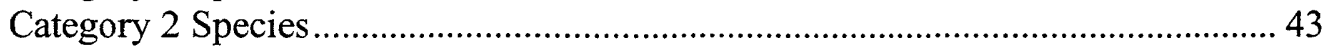

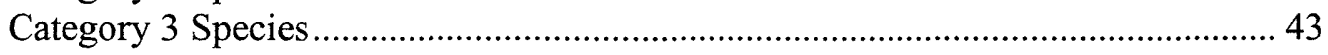

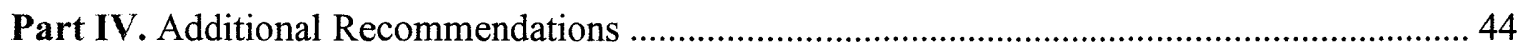

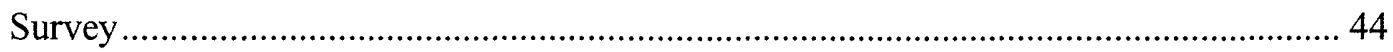

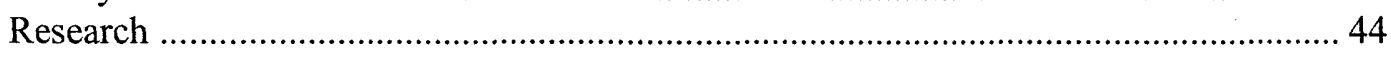

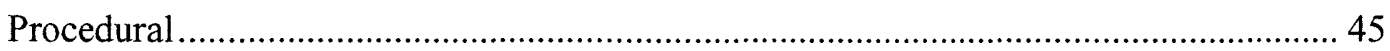

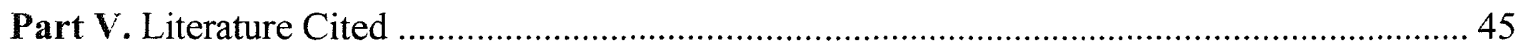

Appendix A. Sequoia-Kings Canyon National Parks - priority alien species by species

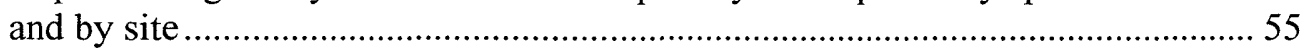

Appendix B. Yosemite National Park - priority alien species by species and by site ................... 61

Appendix C. Field notes of Sequoia-Kings Canyon National Parks survey crews ...................... 71

Appendix D. Yosemite National Park alien plant species along roadsides ................................. 92

Appendix E. Yosemite National Park alien plant species along trails....................................... 98

Appendix F. Yosemite National Park alien plant species in and around corrals and stables ...... 103

Appendix G. Statewide distributions of priority alien plant species ........................................ 107 
Appendix H. Maps of survey areas and selected species:

Sequoia and Kings Canyon National Parks (in green)

Map 1. Sequoia-Kings Canyon National Parks survey areas ........................................ 122

Map 2. Broad distribution priority \#3 alien plant species .......................................... 123

Map 3. Localized wild land priority \#1 alien plant species - map 1 ............................... 124

Map 4. Localized wild land priority \#1 alien plant species - map 2 ............................... 125

Map 5. Localized fruit and nut priority \#1 alien species............................................... 126

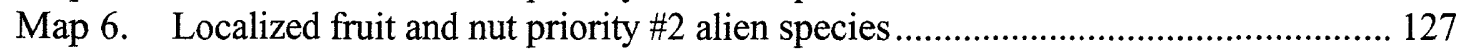

Map 7. Localized legume priority \#1 alien species...................................................... 128

Map 8. Localized ornamental priority \#1 alien species - map 1 .................................... 129

Map 9. Localized ornamental priority \#1 alien species - map 2 ................................ 130

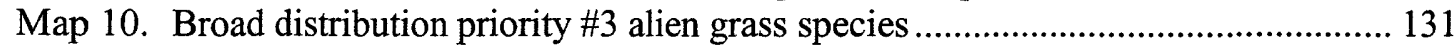

Map 11. Localized wild land priority \#1 alien grass species .......................................... 132

Map 12. Localized wild land priority \#2 alien grass species - map 1 ................................ 133

Map 13. Localized wild land priority \#2 alien grass species - map 2............................. 134

\section{Yosemite National Park (in yellow)}

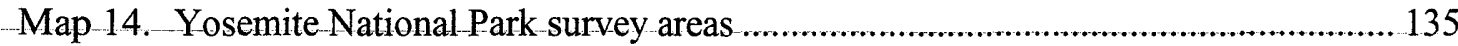

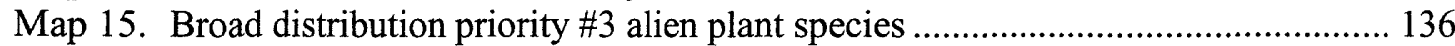

Map 16. Localized wild land priority \#1 alien plant species - map 1 ............................. 137

Map 17. Localized wild land priority \#1 alien plant species - map 2 ............................. 138

Map 18. Localized wild land priority \#1 alien plant species - map 3 ............................... 139

Map 19. Localized wild land priority \#1 alien legume species - map 1 .............................. 140

Map 20. Localized wild land priority \#1 alien legume species - map 2 ......................... 141

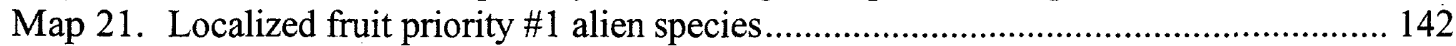

Map 22. Localized ornamental priority \#1 alien species - map 1 .................................. 143

Map 23. Localized ornamental priority \#1 alien species - map 2 .................................... 144

Map 24. Broad distribution priority \#3 alien grass species .............................................. 145

Map 25. Localized wild land priority \#1 alien grass species - map 1............................. 146

Map 26. Localized wild land priority \#1 alien grass species - map 2............................. 147

Map 27. Localized wild land priority \#2 alien grass species - map 1 .............................. 148

Map 28. Localized wild land priority \#2 alien grass species - map 2 2............................. 149

\section{FIGURES}

1. Sequoia-Kings Canyon National Parks alien species richness by elevation ........................... 6

2. Sequoia-Kings Canyon National Parks cluster analysis .......................................................... 11

3. Arrangement of 1999 transects in Yosemite National Park ................................................... 15

4. Yosemite National Park alien species richness by elevation ................................................ 19

5. Yosemite National Park cluster analysis ........................................................................ 23

\section{TABLES}

1. Interpretation of Sequoia-Kings Canyon National Parks cluster analysis................................ 12

2. Alien plant species richness by survey type and by site, Yosemite National Park .................. 17

3. Yosemite National Park 1998 trail survey data ................................................................. 20

4. Yosemite National Park 1999 trail transect and survey data .............................................. 21

5. Interpretation of Yosemite National Park cluster analysis ...................................................... 24

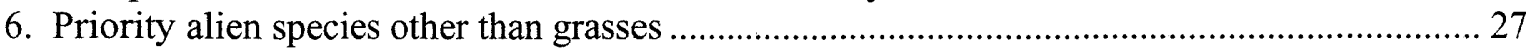

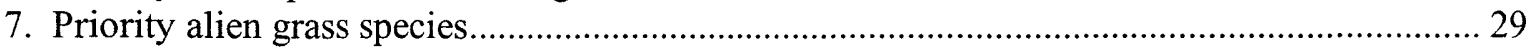


CONVERSION FACTORS

\begin{tabular}{rcl}
\hline Multiply & By & To obtain \\
\hline acre & 4,047 & \\
acre & 0.4047 & square meters $\left(\mathrm{m}^{2}\right)$ \\
foot $(\mathrm{ft})$. & 0.3048 & hectare $(\mathrm{ha})$ \\
mile $(\mathrm{mi})$ & 1.609 & kilometer $(\mathrm{km})$ \\
& & \\
meter $(\mathrm{m})$ & 3.281 & foot $(\mathrm{ft})$ \\
kilometer $(\mathrm{km})$ & 0.6214 & mile $(\mathrm{mi})$ \\
square meter $\left(\mathrm{m}^{2}\right)$ & 0.0002471 & acre \\
hectare (ha) & 2.471 & acre \\
& & \\
\hline
\end{tabular}




\section{Alien Plant Species Threat Assessment and Management Prioritization for Sequoia-Kings Canyon and Yosemite National Parks}

\section{Part I. Introduction}

In 1998, the U.S. Geological Survey began a project to describe the distribution and abundance of alien (nonnative) plants in disturbed areas of Yosemite, Sequoia and Kings Canyon national parks. In this report, and administratively, Sequoia National Park and Kings Canyon National Park are treated as a unit, referred to as Sequoia-Kings Canyon National Parks. Methods were standardized among the parks, thereby laying the groundwork for providing managers with information to assist in managing invasive nonnative plants in the Sierra Nevada national parks. Alien plants were mapped, site characteristics described and permanent records created for evaluating the current status of these plants in the parks, and to provide a basis for managers to decide on appropriate direction and levels of response.

This document reports the results of alien species surveys at Sequoia-Kings Canyon and Yosemite national parks, the findings of a comprehensive literature review of the biology and ecology of all alien plant species found during surveys in the parks, and the ranking of those species for prioritizing management and control programs. Surveys largely were aimed at capturing the distribution and abundance of alien plants, in areas of anthropogenic disturbance. They were designed to complement existing data sets available for each park that documented the distribution and abundance of all species at randomly located sites across broad elevational and latitudinal gradients. Areas of human disturbance targeted for surveys in SequoiaKings Canyon National Parks included campgrounds, corrals, developments, roads, trails and pastures. Surveys in Yosemite National Park focused on campgrounds, corrals, developments, roads and trails. Lower elevation riparian areas and sites of natural disturbance were targeted as well in Sequoia-Kings Canyon National Parks.
Disturbed areas were targeted for inventory because vascular plant surveys in undisturbed sites discovered few of the alien species found during casual observations of heavy use areas. A handful of alien species is well known and has been managed for years in these parks. However, there was clearly a need to document the pattern of alien plant establishment for all other alien species present and to predict those that could pose the greatest threats to the parks.

A comprehensive literature review was done for each species found during the surveys to derive detailed information on biological characteristics (seed production and viability, mode of reproduction, dispersal habits, etc.), on distribution patterns and known invasiveness and on control methods (effectiveness of mechanical, chemical or other treatments). Only a subset of information may be available for some species; no information may be available for others. Detailed and specific information is published for a few. Considered together, known characteristics can help managers compare the potential threat posed by species or categories of species.

The process of ranking alien species for management took into account many of the biological and control factors recommended in the invasive species literature (for examples see Hiebert and Stubbendieck 1993). It empirically blended those factors with local and regional information concerning the invasiveness and ecological impacts of each alien species. This qualitative approach was necessary because of the lack of published data concerning the biological and ecological characteristics of many of the alien species and because the parks encompass a wide range of habitats across an elevational gradient that runs from under $400 \mathrm{~m}$ $(1,310 \mathrm{ft})$ to over $4,400 \mathrm{~m}(14,435 \mathrm{ft})$. Species and site information is provided in the summaries that were compiled from various sources (see Part III). Because of different sampling techniques and management needs, the alien species problems of Sequoia-Kings Canyon National Parks and Yosemite National Park are addressed in separate sections. However, the parks share many of the same problems, and the information for each of the 
parks provides valuable information that can be used to help understand and manage alien plant species in all units of the National Park Service.

\section{Background}

Invasive alien plants can bring about significant changes in park ecosystems by changing structural attributes of native plant communities (physiognomy, species composition, genetic diversity) and the processes that support them (fire, nutrient cycling, hydrology, soil erosion, decomposition) (Macdonald et al. 1988). For instance, the establishment of Tamarix ramosissima (tamarisk) has dramatically altered stream geomorphology in southwestern riparian corridors including the Green River in Canyonlands National Park (Graf 1978) and reduced species richness along the Pecos River in New Mexico and Texas (Brock 1994). In Hawaii Volcanoes National Park, Myrica faya (fire tree) has been shown to profoundly alter nutrient cycling on early successional volcanic sites by increasing the amount of available nitrogen, resulting in further invasion by other nonnative plants (Vitousek and Walker 1989). In addition, annual nonnative grasses have caused an increase in fire frequency in some woodlands (D'Antonio and Vitousek 1992). These are just three of many examples detailing the effects introduced species have on native ecosystems.

Nonnative plants are most likely to establish in areas that have both a source of seeds and that undergo repeated disturbance. In parks and reserves these include developed areas, such as roads and trails, campgrounds, pack stations, water treatment facilities and residential areas (Macdonald et al. 1988, Cowie and Werner 1993). Viable plant parts are transported to these sites via clothing, animal fur and digestive systems, vehicle tires, heavy equipment, slope stabilization materials, and wind (Hodkinson and Thompson 1997, Ridley 1930, Schmida and Ellner 1983). In natural systems, river corridors and riparian areas are especially vulnerable (DeFerrari and Naiman 1994, and others) because: they are subject to regular disturbance, rivers are agents of propagule transport, and moisture is readily available throughout the year (Pyšek and Prach 1995). Alien plant propagules arrive in stream systems via many of the same vectors as those active in terrestrial sites with the addition of wading birds and water transport among stream reaches.

Although not all alien plants are immediately invasive, many nonnative plants appear to undergo a lengthy period of establishment, remaining restricted to roadsides and disturbed areas for years before invading adjacent native vegetation. Populations may then grow exponentially, and a species initially thought to pose little or no threat, as a roadside weed can become a serious pest. Mimosa pigra (catclaw mimosa), for example, was unrecognized as a serious weed in the Northern Territory of Australia until 80 years after it was introduced; it is now considered one of the most important wetland weeds in the region (Cowie and Werner 1993).

Invasive nonnative plants currently infest an estimated 2.8 million hectares (ha) of National Park System lands, costing millions of dollars annually in control efforts (National Park Service 1996). In Yosemite, approximately $\$ 17,500$ is spent on control each year. This amount doubles when in-kind contributions are included (S. Fritzke, oral commun.). At SequoiaKings Canyon National Parks, a small volunteer program, under staff direction, has been relied on in the past to address alien plant management. However, in 2001, an alien management program invested significant funds in the control of alien populations. Inventories of the current distribution of alien species addresses the need of managers to have information on all potential invaders so that priorities can be established for monitoring and control.

\section{Study Areas}

Sequoia-Kings Canyon National Parks forms a contiguous reserve of 349,525 ha of land located on the western slope of the south-central Sierra Nevada of California. This reserve ranges in elevation from $400 \mathrm{~m}(1,310 \mathrm{ft})$ in the western foothills to $4,418 \mathrm{~m}(14,495 \mathrm{ft})$ on the crest of the Sierra Nevada and is composed of rugged, mountainous terrain; over 70 percent of parklands are above $2,500 \mathrm{~m}(8,200 \mathrm{ft})$ elevation. Three major river systems-the 
Kings, Kern and Kaweah-originate within and drain the park; additionally, the northernmost boundary of Kings Canyon National Park includes a portion of the headwaters of the south fork of the San Joaquin River.

Yosemite National Park is a 302,768 ha reserve located in the central Sierra Nevada. It ranges in elevation from $640 \mathrm{~m}(2,100 \mathrm{ft})$ in the Merced River Canyon to $3,997 \mathrm{~m}(13,110 \mathrm{ft})$ atop $\mathrm{Mt}$. Lyell. The park comprises two major watersheds, the Merced River in the south and the Tuolumne River in the north, and completely encompasses the headwaters of each. Twothirds of Yosemite lies between 2,100 m and $3,050 \mathrm{~m}$, resulting in a higher proportion of forested terrain than the southern parks and a lower proportion of alpine habitat.

The vegetation of all three parks is quite varied, reflecting the substantial environmental heterogeneity created by a large elevational gradient. Vegetation types include chaparral, oak woodland, upland hardwood forest, conifer forest and woodland, meadows, and alpine plant communities (Vankat 1982, Haultain et al. 1988, Moore 1993). The parks support rich and diverse vascular floras with nearly 1,500 taxa in both Sequoia-Kings Canyon and in Yosemite.

With the arrival of Europeans in the 1850s, livestock grazing became prevalent and intense throughout the region, continuing in the foothills until the parks were established in 1890 (Macdonald et al. 1988). Grazing was suppressed more slowly over the next two to three decades at the higher elevations. During this time, Mediterranean annual grass species became established in the lower elevations, marking a shift to dominance by nonnative species in the understory of the blue oak savannah and in foothill grassland sites, which persists throughout California (Rejmanek et al. 1991). Grazing is currently limited in the foothills to a government pasture at each park and in the montane and subalpine areas to recreational and administrative pack stock pastures.

Today, visitation has reached 1.4 million at Sequoia-Kings Canyon National Parks and nearly 4 million at Yosemite National Park. In
1998, an estimated 2.1 million visitors to Yosemite entered Yosemite Valley, over 90 percent of them in private vehicles (NPS 2000, IA:3-97). Commercial vehicles (vendors, contractors) travel from various parts of the region to support concession and administrative functions (P. Moore, personal observation). Pack stock animals are moved in and out of the parks seasonally to gain access to winter pastures. Native herbivores migrate into and around the parks to follow forage availability as well (S. Thompson, pers. commun.). Alien plants are faced with few barriers to their transport across parklands, but information is the first step toward addressing the issues.

Note: Because Sequoia National Park and Kings Canyon National Park are administered as a single unit (despite their legislative designations as individual national parks), a single team surveyed them. Therefore, they are referred to here as if they are a single unit and contrasted with Yosemite National Park approximately 40 $\mathrm{km}$ north. Alien species occurrence is presented for Sequoia-Kings Canyon National Parks as if they are one unit; however, species occurrence is documented by site and summary information could be derived for each park separately should the need arise.

\section{Part II. Directed Survey Results}

\section{Sequoia and Kings Canyon National Parks}

\section{Survey and Quadrat Data Collection}

Field Methods - In 1996, 1997, and 1998 directed surveys were conducted in SequoiaKings Canyon National Parks to assess the richness, distribution and abundance of alien plant species. The surveys consisted of complete inventories of all alien (nonnative) plant species present within the boundaries of the target site. These surveys were supplemented by quadratbased sampling of some campgrounds, camps, developments and pack stations in 1998. Surveys were completed in areas where alien plant species are most likely to be introduced and dispersed. The sites surveyed included campgrounds, developed areas, trails, improved roads, dirt roads, pack stations, pastures and riparian zones. Developments and developed 
areas refer to areas that are significantly altered by the installation of structures, utilities and pavement such as accommodations, visitor centers and offices. Surveys at Lodgepole Campground, Lodgepole Village and Ash Mountain developed areas, Wuksachi Village construction site, and along Generals Highway did not record all alien plant species due to logistical constraints. Also, at several sites, the surveys included portions of natural areas, trails, roads, and developments adjacent to the particular site. Except for the Ash Mountain Development survey, which identified 71 alien plant species, data from surveys that did not completely sample a well-defined site were not included in site-by-elevation figures or the cluster analyses described later in this report. The data for Grunnigan Ranch contain a large number of cultivated alien plants and is not included in the figures or cluster analyses. Additionally, a few sites were sampled using quadrat techniques but only the alien species richness data are presented in this report. However, all of the data collected during the surveys and quadrat sampling were considered in the alien species prioritization and recommendations sections of this report.

The Sequoia-Kings Canyon National Parks survey crews assigned each site to a particular site category, e.g. campground. However, the criteria they used to define site types were not the same as those used by the Yosemite crew. In general, the criteria used by the Yosemite crews produced smaller and more sharply defined survey areas. The extensive documentation of site characteristics in the Sequoia-Kings Canyon National Parks survey reports allowed the assignment of alien plant species to comparable site types based on the Yosemite site definitions. In a small number of cases an alien species could either not be assigned to a group other than "natural area" or was part of a very small supplemental survey such as an improved road adjacent to a campground. In those cases, the survey data were not included in the site-byelevation figures or in the cluster analyses but have been included in the alien species prioritization and recommendations sections of this report. The alien species presence/absence survey data for the $55 \mathrm{~km}$ long Rae Lakes Loop Trail and the $19 \mathrm{~km}$ long Kern Canyon Trail were divided into $305 \mathrm{~m}(1,000 \mathrm{ft})$ elevational segments of undetermined lengths based on statements in the survey reports.

Survey reports were conducted throughout the sites. Environmental factors for each alien species found were recorded. Factors included elevation, slope, aspect, percent canopy closure, community type, associated species, abundance, and distribution. Abundance figures were taken according to a logarithmic scale $(1-10,11-100$, 101-1000, and $>1000$ ). These figures reflect the number of individuals of a single species observed throughout the entire survey area. Distribution observations for each alien species were categorized as scattered individuals, scattered clumps of individuals, large clumps of many individuals, or widespread throughout the area. The survey crews also recorded brief written descriptions of each species found. Descriptions included additional environmental factors such as type and intensity of disturbance. Universal Transverse Mercator coordinates were recorded for each species. These coordinates were obtained from either a PLGR-type global positioning device or directly from USGS $7.5^{\prime}$ quadrangles. Hickman (1993) was used to determine which plant species were not indigenous to the parks.

The quadrat-based sampling method was conducted in 1998 only at campgrounds/camps, developments and pack stations. A baseline transect was first established along one edge of each patch, and a random number table was used to randomly place sampling transects perpendicularly along the length of the baseline. Quadrats $\left(1 \mathrm{~m}^{2}\right)$ were placed randomly along the sampling transects until thirty quadrats had been sampled. When thirty quadrats were sampled before the end of a sampling transect, the remainder of the sampling transect was also sampled to avoid biasing the data toward the beginning of the transect. In each quadrat, the cover of nonnative and native plant species was estimated to the nearest one percent. While the cover of a particular species could not exceed 100 percent, the total of all species in the quadrat frequently exceeded 100 percent. Additionally, a natural vegetation control site was established in undisturbed vegetation $50 \mathrm{~m}$ from one of three site categories. 
The sample sites frequently contained areas such as parking lots or tent pads that were inappropriate for sampling, so quadrats had to pass rejection criteria before field crews sampled them. Randomly placed quadrats were rejected if more than 50 percent of the cover was incapable of supporting plant life (pavement, dirt roads, large boulders and trampled areas within $1 \mathrm{~m}$ of a structure). Areas where alien plants were deliberately cultivated (lawns, flower pots and gardens) were also rejected. If the crews rejected several quadrats, they added additional transects until 30 quadrats were sampled. In areas that were sampled for cover, the canopy cover of shrubs and trees was also recorded. Shrub cover along the length of transects was measured using the line intercept method. At each site, 100 canopy points were distributed at regular intervals along the transect. Field crews used GRS brand densiometers to obtain canopy cover estimates. The quadrat sampling data were analyzed for alien species richness and are included in the richness-by-elevation figures below.

\section{Decline of Alien Species Richness with Increasing Elevation}

All sites - Graphs of alien species richness against site elevation indicate that alien species richness is strongly negatively correlated with elevation when all sites are pooled (fig. 1a). This negative correlation is evident for six of the seven site types when the graphs are restricted to particular site types (fig. 1b-1h). The siterestricted graphs also indicate that each site type is restricted to limited portions of the elevational gradient that runs from $425 \mathrm{~m}(1,400 \mathrm{ft})$ to 3,300 $\mathrm{m}(10,800 \mathrm{ft})$ and sampling effort varied with elevation and site type. These are unavoidable problems when only a limited number of discrete sites are available for sampling, and they affect the inferences that can be made from the data. On the positive side, for some site types, such as camps and pack stations, the entire population of sites was sampled so statistical models are not required to predict the number of alien species at another site that was not sampled.

Campgrounds/Camps - Alien species richness in campgrounds is likely due to differences in both the distribution of habitat types along the elevational gradient, as well as the location and types of disturbances. Potwisha Campground $(645 \mathrm{~m} ; 2,115 \mathrm{ft})$ with 44 species distributed over $48,000 \mathrm{~m}^{2}$, lies on an ecotone between blue oak woodland and canyon live oak woodland vegetation types. While its location on an ecotone suggests that it may have a large number of alien species because of diverse habitats, almost all of the alien species present were either common in the blue oak woodland vegetation type or are soil disturbance specialists. Buckeye Campground ( $860 \mathrm{~m} ; 2,820$ ft) with 25 species distributed over $8,000 \mathrm{~m}^{2}$, and South Fork Campground $(1,140 \mathrm{~m} ; 3,730 \mathrm{ft})$ with 15 species distributed over $9,000 \mathrm{~m}^{2}$, are both located in canyon live oak. They contain many of the same alien annual grass species but Buckeye had a more diverse alien forb flora (e.g. nongrass, nongrasslike herbs).

Sheep Creek Campground $(1,390 \mathrm{~m} ; 4,565 \mathrm{ft})$ with 7 species distributed over $96,000 \mathrm{~m}^{2}$, and Moraine Campground $(1,450 \mathrm{~m} ; 4,765 \mathrm{ft})$ with 3 species distributed over $106,000 \mathrm{~m}^{2}$, are located in mixed conifer vegetation with broken canopies and sandy soil. The dominant alien species at both sites were Bromus tectorum (cheat grass) and Vulpia myuros (rattail fescue), both of which are short-lived annual grasses. Sheep Creek's greater species richness was due to a few perennial species that are restricted to areas that receive supplemental water such as ditches and drinking fountains.

Swale Administrative Campground $(1,900 \mathrm{~m}$; $6,225 \mathrm{ft}$ ), which had 6 species, distributed over $10,000 \mathrm{~m}^{2}$, is located in mixed conifer vegetation. Atwell Mill Campground (1,955 m; $6,415 \mathrm{ft}$ ) is located in white fir/big tree vegetation and had 5 species distributed over $17,000 \mathrm{~m}^{2}$. They had similar alien species compositions except that no grasses were present at Swale while all the alien species at Atwell Mill Campground were located in a single seep that is dominated by Poa pratensis (Kentucky bluegrass). Azalea Campground $(1,970 \mathrm{~m} ; 6,455 \mathrm{ft})$ with 16 species distributed over $76,000 \mathrm{~m}^{2}$, Crystal Springs Campground $(2,020 \mathrm{~m} ; 6,630 \mathrm{ft})$ with 5 species distributed over $65,000 \mathrm{~m}^{2}$, and Dorst Campground $(2,050$ $\mathrm{m} ; 6,720 \mathrm{ft}$ ) with 19 species distributed over $140,000 \mathrm{~m}^{2}$, are all located in white fir vegetation interspersed with montane meadow vegetation. The alien species at Azalea were 


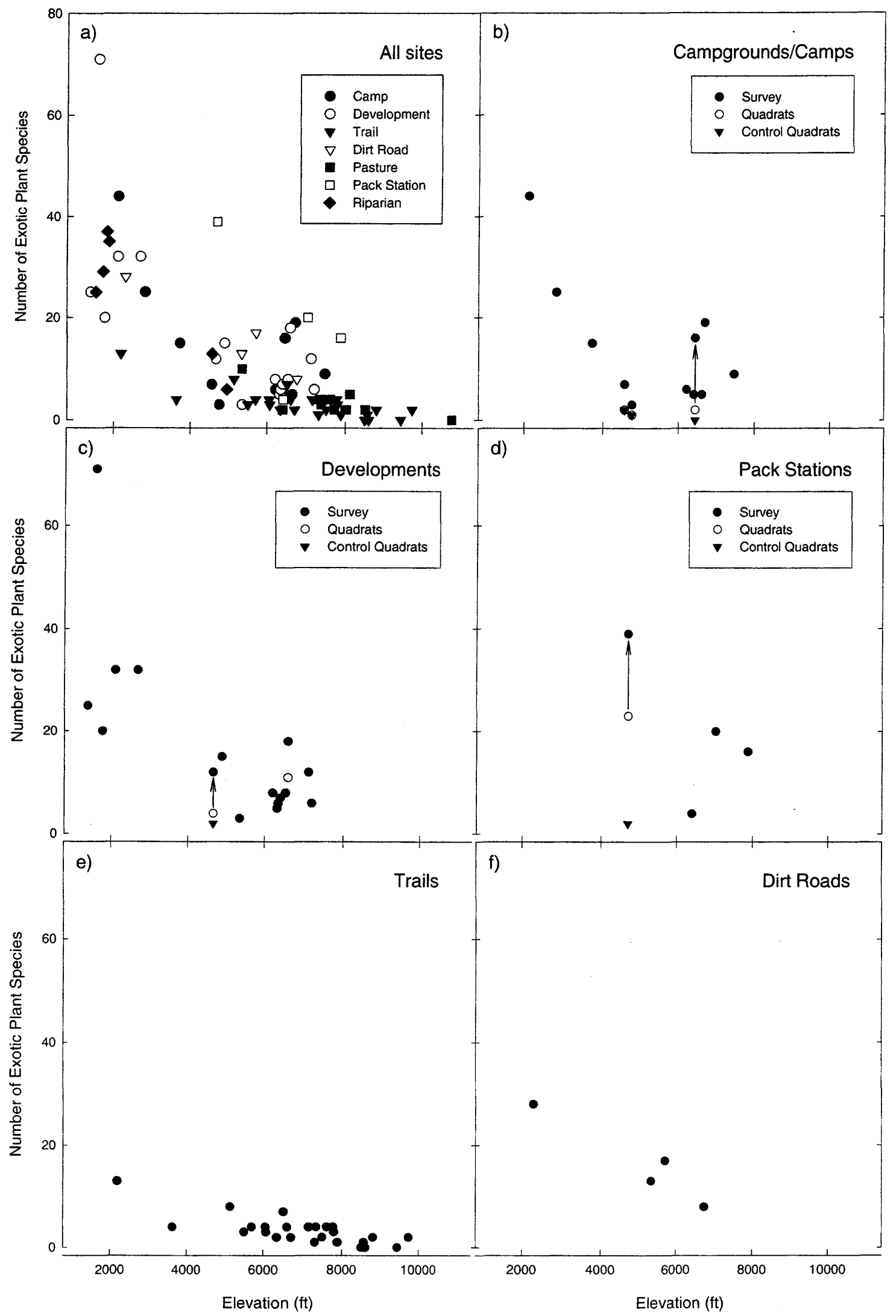

Figure 1. Sequoia-Kings Canyon National Parks alien species richness by elevation. 


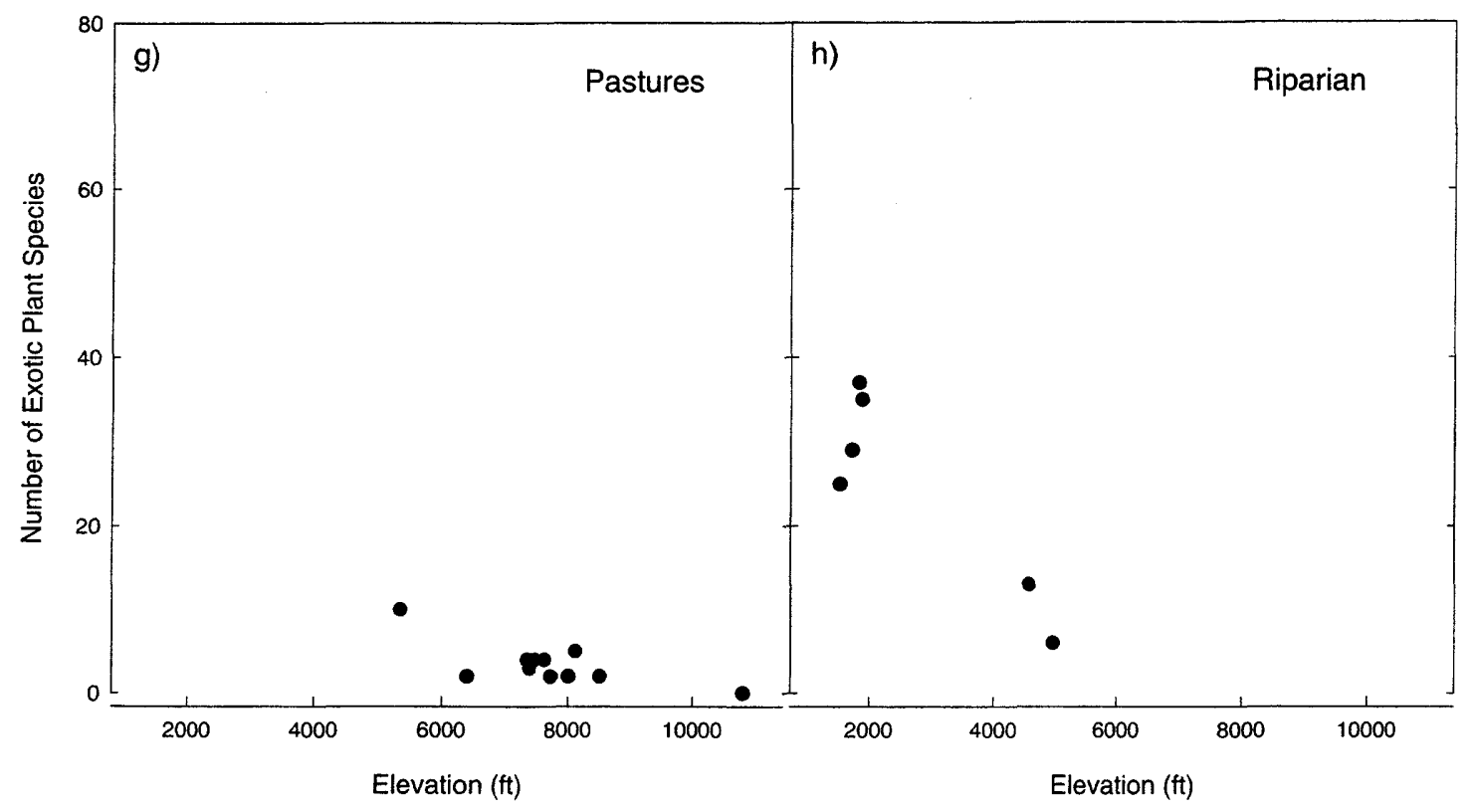

Figure 1. Sequoia-Kings Canyon National Parks alien species richness by elevation--Continued

found during the comprehensive survey primarily in a highly disturbed and trampled portion of a meadow at the southwest corner of the campground or in seeps and wet areas. Consequently, the quadrat-based sampling ( 2 species over $30 \mathrm{~m}^{2}$ sampling area) missed most of the alien species (see arrow in fig. 1b). No alien species were found in the control quadrats outside of the campground. This suggests that the alien species in the campground are not invading adjacent undisturbed vegetation; however, no comprehensive survey was made of the control site and many of the alien species are restricted to wet microhabitats. The alien species at Crystal Springs Campground were primarily restricted to the margin of a relatively undisturbed meadow. In contrast, at Dorst Campground most of the alien species were found in disturbed soils near roads and structures. Cold Springs Campground (2,280 m; $7,475 \mathrm{ft}$ ) with 9 species discovered, is located in Jeffrey pine/fir vegetation and most of the alien species were found along moist roadsides or in dirt roadbeds.

Developments - There were clear changes in alien species richness and composition with changes in site elevation among developments (fig. 1c). Additionally, the type of development strongly influenced alien species richness and composition.
Ash Mountain Boundary Area (425 m; 1,400 ft) with 25 species distributed over $2,000 \mathrm{~m}^{2}$, and North Fork Parking Lot $(540 \mathrm{~m} ; 1,775 \mathrm{ft})$ with 20 species distributed over $3,000 \mathrm{~m}^{2}$, contained similar numbers of alien species that are typical of alien annual grassland. Ash Mountain Developed Area $(490 \mathrm{~m} ; 1,605 \mathrm{ft})$ with 71 species distributed over $110,000 \mathrm{~m}^{2}$, had by far the richest alien species flora of any site. The species included typical annual grassland species, species that are lawn and disturbed soil specialists, horticultural species, and waifs. Middle Fork Flume (645 m; 2,110 ft) had 32 species and Hospital Rock $(820 \mathrm{~m} ; 2,695 \mathrm{ft})$ with 32 species distributed over $12,000 \mathrm{~m}^{2}$ were similar to the Ash Mountain Boundary and North Fork Parking Lot sites except that they contained a richer annual grassland forb flora. The alien flora of Cedar Grove Market and Lodge $(1,425 \mathrm{~m} ; 4,670 \mathrm{ft})$, with 12 species distributed over $21,000 \mathrm{~m}^{2}$, appeared to have lost most of the typical annual grassland alien species that were found at lower elevations and was a mixture of perennial grasses (Poa pratensis and Poa bulbosa [bulbous bluegrass]), species that specialize in disturbed soil, and short lived annual grasses (Bromus tectorum and Vulpia myuros). 
The floras of Crystal Cave Parking Lot $(1,490$ $\mathrm{m} ; 4,895 \mathrm{ft}$ ) with 15 species distributed over $4,000 \mathrm{~m}^{2}$, and Milk Ranch Lookout $(1,895 \mathrm{~m}$; $6,210 \mathrm{ft}$ ) with 8 species distributed over 3,000 $\mathrm{m}^{2}$, were very similar and contained many alien species that are typical of low elevation annual grassland, as well as Bromus tectorum, which is typical of mid-elevation sites. Oriole Lake Airstrip $(1,630 \mathrm{~m} ; 5,355 \mathrm{ft})$ had three species: two species of low elevation annual grasses and Plantago lanceolata (English plantain).

The Big Stump Picnic Area (1,925 m; 6,325 ft) flora, with 5 species distributed over $5,000 \mathrm{~m}^{2}$, was dominated by Bromus tectorum and soil disturbance-adapted forbs. With the exception of Bromus tectorum at the Giant Forest Sewage Treatment Plant $(1,935 \mathrm{~m} ; 6,350 \mathrm{ft} ; 6$ species distributed over $2,000 \mathrm{~m}^{2}$ ) the flora of that site and of the Giant Forest Developed Area (1,960 $\mathrm{m} ; 6,440 \mathrm{ft}$; with 6 species distributed over $95,000 \mathrm{~m}^{2}$ ) consisted of species that were represented by few individuals. Columbine Picnic Area $(1,990 \mathrm{~m} ; 6,535 \mathrm{ft})$ with 8 species distributed over $5,000 \mathrm{~m}^{2}$, and Grant Grove Developed Area $(2,010 \mathrm{~m} ; 6,595 \mathrm{ft})$ with 18 . species distributed over $200,000 \mathrm{~m}^{2}$, were noteworthy for their large populations of Phalaris arundinacea, Poa pratensis and Trifolium repens (reed canary grass, Kentucky bluegrass and white clover, respectively).

The floras of Red Fir Maintenance Yard (2,170 $\mathrm{m} ; 7,120 \mathrm{ft}$ ) with 12 species over $20,000 \mathrm{~m}^{2}$, and Wolverton Snow Play Area were dominated by forb species adapted to soil disturbance. Overall, annual grass species typical of low-elevation annual grassland tended to disappear at elevations between 3,000 and 4,000 feet except for very open or disturbed sites. With increasing elevation, the low elevation annual grasses were replaced by Bromus tectorum on dry, open sites and Poa pratensis on more mesic sites. Additionally, many of the annual forbs present in low elevation annual grassland were present in disturbed areas to elevations of $2,195 \mathrm{~m}$ $(7,200 \mathrm{ft})$, but they were replaced by perennial forbs such as Cirsium vulgare, Taraxacum officinale and Trifolium repens (bull thistle, dandelion and white clover) on less disturbed mesic sites.
Pack Stations - The alien floras of the pack stations at Cedar Grove $(1,435 \mathrm{~m} ; 4,700 \mathrm{ft}$; with 39 species over $\left.3,000 \mathrm{~m}^{2}\right)$, Grant Grove $(1,955$ $\mathrm{m} ; 6,415 \mathrm{ft}$; with 4 species distributed over $\left.3,000 \mathrm{~m}^{2}\right)$, Wolverton $(2,145 \mathrm{~m} ; 7,035 \mathrm{ft}$; with 6 species distributed over $64,000 \mathrm{~m}^{2}$ ), and Mineral King $(2,400 \mathrm{~m} ; 7,880 \mathrm{ft}$; with 16 species over $13,000 \mathrm{~m}^{2}$ ) were dominated by low- and midelevation annual grasses and forb species adapted to soil disturbance and dispersal by grazing animals. The quadrat-based survey ( 30 $\mathrm{m}^{2}$ ) of Cedar Grove pack station detected only 23 alien species while the control, which was located in a ponderosa pine/incense-cedar forest, detected only 2 alien species (fig. 1d). Those species, Bromus tectorum and Vulpia myuros, were only present in 3 percent of the quadrats at 1 percent cover for each species. The very low species richness at the Grant Grove pack station was due to the fact that pack animals had been placed in the corrals prior to the survey and most plants had been eaten or trampled beyond recognition. The two higher elevation pack stations contained Poa pratensis, Taraxacum officinale, Trifolium repens, Rumex acetosella (sheep sorrel) and Spergularia rubra (sandspurrey), all species that occur in mid- to highelevation grazed meadows.

Trails - The trail floras were low in alien species richness, and alien species could be assigned to one of three categories based on elevation (fig. le). Between $610 \mathrm{~m}(2,000 \mathrm{ft})$ and $1,220 \mathrm{~m}(4,000 \mathrm{ft})$, the trails were lined with annual species that are typical of low elevation annual grassland. From 1,525 $\mathrm{m}(5,000 \mathrm{ft})$ to $2,440 \mathrm{~m}(8,000 \mathrm{ft})$, the trails were lined with $P o a$ pratensis, Bromus tectorum, Taraxacum officinale and other forbs while Cirsium vulgare was common at stream crossings and in wet areas. Trails between $2,440 \mathrm{~m}(8,000 \mathrm{ft})$ and $3,050 \mathrm{~m}(10,000 \mathrm{ft})$ were lined only with Poa pratensis and Taraxacum officinale.

Dirt Roads - The alien flora of dirt roads was similar to that of the trail flora except for a greater number of forb species adapted to soil disturbance (fig. 1f). The flora of Colony Mill Road (705 m; 2,305 ft) with 28 species, was dominated by species typical of low elevation annual grassland and blue oak woodland. Cattle from an adjacent private inholding were seen 
grazing along Oriole Lake Road (1,630 m; 5,340 $\mathrm{ft}$ ), which probably accounts for the presence of Trifolium repens which is dispersed in dung. The flora was dominated by Bromus tectorum, Bromus diandrus (ripgut brome) and a few soil disturbance adapted forb species. Bromus tectorum, low elevation annual grasses and disturbance-adapted forbs were present along Mineral King Road $(1,740 \mathrm{~m} ; 5,720 \mathrm{ft}, 17$ species) and Camp Conifer Road $(2,060 \mathrm{~m}$; $6,755 \mathrm{ft}, 8$ species).

Pastures/Montane Meadows - Pastures were different habitats for alien species than all of the previous site types because they contained vegetation that is dominated by native species. Alien species that were established in pastures, all of which were identified as montane meadow vegetation, demonstrated their ability to invade those natural habitats. Oriole Lake Pasture $(1,630 \mathrm{~m} ; 5,355 \mathrm{ft})$ with 10 species, contained twice as many alien species as the other pastures (fig. $1 \mathrm{~g}$ ). The probable explanation is its proximity to a dirt road and increased seed dispersal and grazing disturbance by cows from a nearby private inholding. Many of the grasses and forbs in the pasture are known to be dispersed in horse and cow dung. Half of the pastures between $1,830 \mathrm{~m}(6,000 \mathrm{ft})$ and $2,745 \mathrm{~m}$ $(9,000 \mathrm{ft})$ contained only two alien species, Poa pratensis and Taraxacum officinale, while the remainder contained those species plus one to three other species. The survey crew's notes indicate that dense populations of Poa pratensis appeared to be excluding native species at many higher-elevation sites.

Riparian Areas - The habitats of the streamside sites shared characteristics with both the pasture/montane meadow sites and the humanmodified habitat sites. They resembled montane meadows because native plants were present in abundance along their banks, and they resembled human-modified habitats because some areas of their banks, and much of their beds, were periodically cleared of all vegetation. Vegetation clearing through either human modification or flooding creates bare ground that can allow for the establishment of alien plant propagules. Alien species richness was high, because moisture is available for much of the growing season and because the riparian sites that were completely sampled are at lowand mid-elevations (fig. $1 \mathrm{~h}$ ). The survey crews collected more data for riparian areas than were reported here. Except for the following six sites, most of the data were collected as part of broader surveys, and it was not clear from the survey notes how complete those surveys were (complete survey information is presented in species distribution maps 1--28). Additionally, the six riparian sites reported here are located between two very narrow elevational bands (460 $\mathrm{m}$ to $1,525 \mathrm{~m} ; 1,500$ to $5,000 \mathrm{ft}$ ).

The 25 alien plant species found in the drainage of the middle fork of the Kaweah River (470 m; 1,545 ft) included Ficus carica, Morus alba, and Tamarix (edible fig, white mulberry and tamarisk, respectively), all species that are highly invasive in riparian areas in California. Rubus discolor (Himalayan blackberry) and Tamarix species are invading the north fork of the Kaweah River (525 m; 1,725 ft, 29 species), and the survey crew noted the presence of some cows that had eaten and trampled most of the vegetation in the stream bed. Yucca Creek's $(575 \mathrm{~m} ; 1,880 \mathrm{ft})$ flora with 37 species contained actively invading populations of Juglans regia (English walnut), Juglans californica (California black walnut), Ficus carica, Rubus discolor, Vitis vinifera (cultivated grape). Additionally, the nearby Grunnigan Ranch site hosted Carya, Diospyro, Nerium oleander, Punica granatum, Pyracantha angustifolia and Rubus discolor (pecan, persimmon, oleander, pomegranate, firethorn and Himalayan blackberry, respectively), all species that are capable of rapidly expanding along riparian corridors and with fruit that may be dispersed over long distances by birds. Nerium oleander, a very toxic evergreen shrub species native to stream banks and stream beds in the Mediterranean region, is especially dangerous as its seed is dispersed by wind and water and its natural habitat is the same as that required by California's sycamores, alders, willows and cottonwoods (Keeley 1992). The Sycamore Creek ( $575 \mathrm{~m} ; 1,880 \mathrm{ft})$ flora of 35 species was being invaded by Arundo donax (giant reed), Pyracantha angustifolia, and Tamarix species. The field survey crews observed evidence of recent attempts to eliminate the Arundo donax (giant reed) population. The survey crews noted 
that Malus sylvestris (apple) appeared to be spreading in Trauger's Creek $(1,395 \mathrm{~m} ; 4,575 \mathrm{ft}$, 13 species total) and that the portion of the Kings River $(1,515 \mathrm{~m} ; 4,965 \mathrm{ft}, 6$ species total) near Zumwalt Meadow (Cedar Grove) contained populations of Poa pratensis, Bromus tectorum, and Cirsium vulgare.

\section{Similarity of Alien Species Composition Among Sites}

To compare and contrast species composition among sites, an exploratory cluster analysis of the sites included in the species richness by elevation figures was conducted using PC-ORD version 4 (fig. 2). Before the analysis was run, all species with occurrences at only one or two sites were excluded from the data matrix. In an analysis of sites with native species the low frequency species would have been left in the data matrix as indicator species. However, in the case of alien species, the low frequency species are typically species that have not been widely dispersed and not species that are limited to a narrow set of environmental conditions. A variety of distance measurements and group linkage methods were used to analyze the data and Euclidean distances combined with Ward's group linkage method produced the most interpretable clusters, which are presented in figure 2.

An ecological interpretation of the factors that significantly affected the clustering of the alien species is presented in table 1 . Note that the sites with no alien species have been added to the table as an unnumbered cluster. The coarsest division of the sites can be attributed to the presence of high species richness of lowelevation species such as those commonly found in annual grasslands and blue oak woodlands. This result is expected because of the negative correlation between alien species richness and elevation. When Euclidean distances are used as a measure of resemblance between sites based on species abundance or presence/absence data, a problem known as the double-zero effect may occur (Legendre and Legendre 1998). The problem arises because the algorithm for calculating the resemblance value using the
Euclidean distance method does not differentiate between sites that share the same species and sites from which the same species are absent. For this reason the Euclidean distance method is generally recommended for comparing sites based on environmental factors and not recommended for comparisons based on species abundance or presence/absence data (Legendre and Legendre 1998). However, on close examination, that recommendation assumes that the analysis is being conducted to compare the results against the expectations of ecological niche theory. That theoretical test is not the purpose of the parks' alien species surveys. The negative correlation of alien species richness with increasing elevation resulted in the doublezero effect that is manifested in the close resemblance between the clusters of high elevation, alien-species-poor sites in figure 2 . Because Ward's method is an agglomerative hierarchical clustering technique, the first clusters are pair-wise mergers of the most similar sites. Hence, the shorter the initial "legs" of the dendrogram in figure 2, the more closely the site pairs resemble each other. Therefore, because there are only a few species found at higher elevations, the double-zero effect results in a tendency for the higher-elevation sites to resemble each other. The high-elevation sites lacked many of the same species and the lower elevation sites resemble each other because of the species they have in common. The next coarsest divisions are among xeric and mesic sites for sites rich in low-elevation species, sites that are dominated by mid- and high-elevation grass species with low forb diversity, and sites with a relatively high diversity of mid- to highelevation forbs (table 1).

The interpretation of clusters 1 through 5 , sites rich in low-elevation species, is straightforward as indicated in table 1 . All of the sites in those clusters range in elevation from $395 \mathrm{~m}$ to $855 \mathrm{~m}$ $(1,300 \mathrm{ft}$ to $2,800 \mathrm{ft})$. The sole exception to this elevational range is the Cedar Grove Pack Station at an elevation of $1,435 \mathrm{~m}(4,700 \mathrm{ft})$ which is very rich in low-elevation species such as Bromus diandrus, $B$. hordeaceus, $B$. madritensis, Erodium cicutarium and Lolium multiflorum (ripgut brome, soft chess, red brome, red-stemmed filaree, and Italian ryegrass, respectively). 


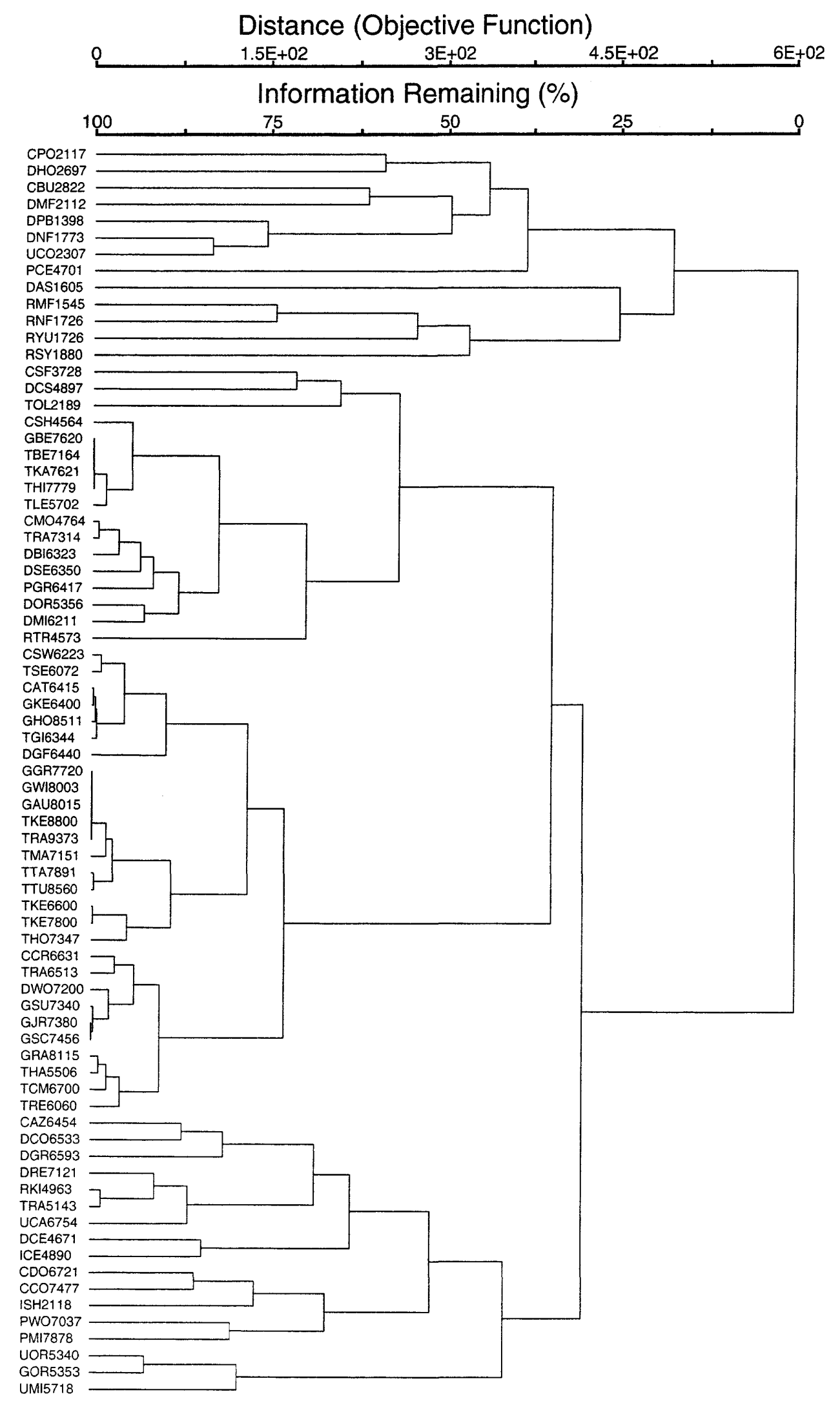

Figure 2. Sequoia-Kings Canyon National Parks cluster analysis. 
Table 1. Interpretation of Sequoia-Kings Canyon National Parks cluster analysis.

\begin{tabular}{|c|c|c|c|c|c|c|c|}
\hline \multicolumn{5}{|c|}{ Cluster Characteristics } & Code & Site & Cluster \\
\hline \multirow{5}{*}{ 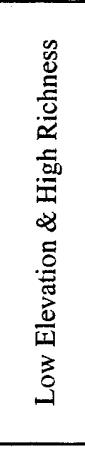 } & \multirow{3}{*}{ 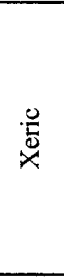 } & \multicolumn{3}{|c|}{ High Forb Richness } & $\begin{array}{l}\text { CPO2117 } \\
\text { DHO2697 }\end{array}$ & $\begin{array}{l}\text { Potwisha Campground } \\
\text { Hospital Rock Picnic Area }\end{array}$ & 1 \\
\hline & & \multicolumn{3}{|c|}{ Moderate Forb Richness } & $\begin{array}{l}\text { CBU2822 } \\
\text { DMF2112 } \\
\text { DPB1398 } \\
\text { DNF1773 } \\
\text { UCO2307 } \\
\end{array}$ & $\begin{array}{l}\text { Buckeye Campground } \\
\text { Middle Fork Flume } \\
\text { Ash Mountain Park Boundary } \\
\text { North Fork Parking Lot } \\
\text { Colony Mill Dirt Road } \\
\end{array}$ & 2 \\
\hline & & \multirow{2}{*}{\multicolumn{3}{|c|}{$\begin{array}{l}\text { Low and Upper Elevation Spp. } \\
\text { Irrigated - High Richness }\end{array}$}} & PCE4701 & Cedar Grove Pack Station & 3 \\
\hline & \multirow[b]{2}{*}{$\frac{0}{3}$} & & & & DAS1605 & Ash Mountain Headquarters & 4 \\
\hline & & \multicolumn{3}{|c|}{ Riparian } & $\begin{array}{l}\text { RMF1545 } \\
\text { RNF1726 } \\
\text { RYU1829 } \\
\text { RSY1880 } \\
\end{array}$ & $\begin{array}{l}\text { Middle Fork of Kaweah River } \\
\text { North Fork of Kaweah River } \\
\text { Yucca Creek } \\
\text { Sycamore Creek }\end{array}$ & 5 \\
\hline \multirow{7}{*}{ 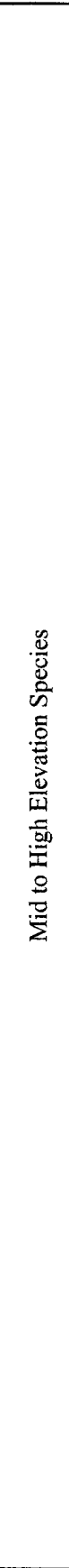 } & \multirow{6}{*}{ 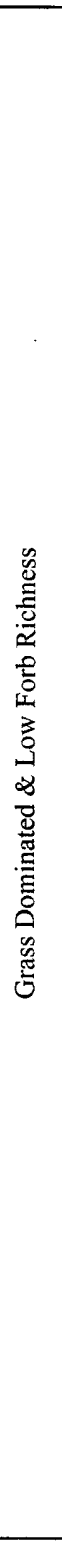 } & \multirow{3}{*}{ 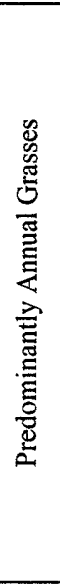 } & \multicolumn{2}{|c|}{$\begin{array}{l}\text { Low Elevation Spp. } \\
\text { Moderate Richness }\end{array}$} & $\begin{array}{l}\text { CSF3728 } \\
\text { DCS4897 } \\
\text { TOL2189 } \\
\end{array}$ & $\begin{array}{l}\text { South Fork Campground } \\
\text { Crystal Cave Parking Lot } \\
\text { Old Hidden Springs Trail } \\
\end{array}$ & 6 \\
\hline & & & 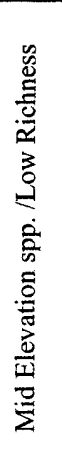 & $\begin{array}{l}\text { Bromus } \\
\text { tectorum } \\
\quad \& \\
\text { Vulpia } \\
\text { myuros }\end{array}$ & $\begin{array}{l}\text { CSH4564 } \\
\text { GBE7620 } \\
\text { TBE7164 } \\
\text { TKA7621 } \\
\text { THI7779 } \\
\text { TLE5702 } \\
\text { CMO4764 } \\
\text { TRA7314 } \\
\text { DBI6323 } \\
\text { DSE6350 } \\
\text { PGR6417 } \\
\text { DOR5356 } \\
\text { DMI6211 } \\
\end{array}$ & $\begin{array}{l}\text { Sheep Creek Campground } \\
\text { Bearpaw Meadow } \\
\text { Giant Forest to Bearpaw Meadow Trail } \\
\text { Bearpaw Meadow to Kaweah Gap Trail } \\
\text { High Sierra Trail } \\
\text { Lewis Creek Trail } \\
\text { Moraine Campground } \\
\text { Rae Lakes Trail ( } 7000 \mathrm{ft}) \\
\text { Big Stump Picnic Area } \\
\text { Giant Forest Sewage Treatment Facility } \\
\text { Grant Grove Pack Station } \\
\text { Oriole Lake Air Strip } \\
\text { Milk Ranch Lookout } \\
\end{array}$ & 7 \\
\hline & & & & Riparian & RTR4573 & Trauger's Creek & 8 \\
\hline & & \multirow{3}{*}{ 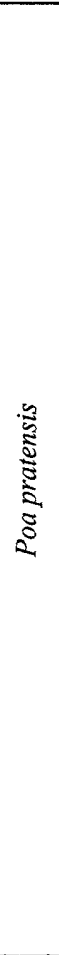 } & \multirow{2}{*}{ 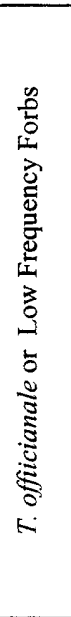 } & $\begin{array}{l}\text { Low } \\
\text { Frequency } \\
\text { Forbs }\end{array}$ & $\begin{array}{l}\text { CSW6223 } \\
\text { TSE6072 } \\
\text { CAT6415 } \\
\text { GKE6400 } \\
\text { GHO8511 } \\
\text { TGI6344 } \\
\text { DGF6440 } \\
\end{array}$ & $\begin{array}{l}\text { Swale Campground } \\
\text { Sequoia Lake Trail } \\
\text { Atwell Mill Campground } \\
\text { Kern Canyon Ranger Station Pasture } \\
\text { Hockett Meadow } \\
\text { Giant Forest Trail } \\
\text { Giant Forest Developed Area } \\
\end{array}$ & 9 \\
\hline & & & & $\begin{array}{l}\text { Forb } \\
\text { Primarily } \\
\text { Taraxicum } \\
\text { officianale }\end{array}$ & $\begin{array}{l}\text { GGR7720 } \\
\text { GWI8003 } \\
\text { GAU8015 } \\
\text { TKE8800 } \\
\text { TRA9373 } \\
\text { TMA7151 } \\
\text { TTA7891 } \\
\text { TTU8560 } \\
\text { TKE6600 } \\
\text { TKA7800 } \\
\text { THO7347 } \\
\end{array}$ & $\begin{array}{l}\text { Grasshopper Meadow } \\
\text { Williams Meadow } \\
\text { Austin Meadow } \\
\text { Kern Canyon Trail }(8000 \mathrm{ft}) \\
\text { Rae Lakes Trail }(9000 \mathrm{ft}) \\
\text { Marvin Pass Trail } \\
\text { Tar Gap Trail } \\
\text { Tuohy Meadow Trail } \\
\text { Kern Canyon Trail }(6000 \mathrm{ft}) \\
\text { Bearpaw Meadow to Kaweah Gap Trail } \\
\text { Atwell Mill Cg. to Hockett Meadow Trail }\end{array}$ & 10 \\
\hline & & & \multicolumn{2}{|c|}{$\begin{array}{c}\text { Presence of } \\
\text { Rumex acetosella } \\
\& \\
\text { Spergularia rubra }\end{array}$} & $\begin{array}{l}\text { CCR6631 } \\
\text { TRA6513 } \\
\text { DWO7200 } \\
\text { GSU7340 } \\
\text { GJR7380 } \\
\text { GSC7456 } \\
\text { GJU8115 } \\
\text { THA5506 } \\
\text { TCM6700 } \\
\text { TRE6060 } \\
\end{array}$ & $\begin{array}{l}\text { Crystal Springs Campground } \\
\text { Rae Lakes Trail (6000 ft) } \\
\text { Wolverton Snow Park } \\
\text { Sugarloaf Meadow } \\
\text { J. R. Meadow } \\
\text { Scaffold Meadow. } \\
\text { Junction Meadow } \\
\text { Hart Loop Trail } \\
\text { Crescent Meadow } \\
\text { Redwood Canyon Trail } \\
\end{array}$ & 11 \\
\hline & 点 & \multicolumn{3}{|c|}{ Miscellaneous Forbs } & $\begin{array}{l}\text { CAZ6454 } \\
\text { DCO6533 } \\
\text { DGR6593 } \\
\text { DRE7121 } \\
\text { UCA6754 } \\
\text { TRA5143 } \\
\end{array}$ & $\begin{array}{l}\text { Azalea Campground } \\
\text { Columbine Picnic Area } \\
\text { Grant Grove Developed Area } \\
\text { Red Fir Maintenance Yard } \\
\text { Kings River } \\
\text { Rae Lakes Trail }(5000 \mathrm{ft})\end{array}$ & 12 \\
\hline
\end{tabular}


Table 1. Interpretation of Sequoia-Kings Canyon National Parks cluster analysis--Continued

\begin{tabular}{|c|c|c|c|c|c|}
\hline \multicolumn{3}{|c|}{ Cluster Characteristics } & Code & Site & Cluster \\
\hline \multirow{2}{*}{ 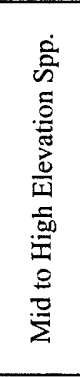 } & \multirow[t]{2}{*}{ 总 } & Miscellaneous Forbs & $\begin{array}{l}\text { UCA6754 } \\
\text { DCE4671 } \\
\text { ICE4890 } \\
\text { CDO6721 } \\
\text { CCO7477 } \\
\text { ISH2118 } \\
\text { PWO7037 } \\
\text { PMI7878 } \\
\end{array}$ & $\begin{array}{l}\text { Camp Conifer Dirt Road } \\
\text { Cedar Grove Market and Lodge } \\
\text { Cedar Grove Paved Road } \\
\text { Dorst Campground } \\
\text { Cold Springs Campground } \\
\text { Shepard Saddle Paved Road } \\
\text { Wolverton Pack Station } \\
\text { Mineral King Pack Station }\end{array}$ & 12 \\
\hline & & $\begin{array}{c}\text { Bromus tectorum, Poa pratensis } \\
\text { Verbascum thapsus } \\
\text { \& Miscellaneous Forbs } \\
\end{array}$ & $\begin{array}{l}\text { UOR5340 } \\
\text { GOR5353 } \\
\text { UMI5718 } \\
\end{array}$ & $\begin{array}{l}\text { Oriole Lake Dirt Road } \\
\text { Oriole Lake Meadow } \\
\text { Mineral King Dirt Road } \\
\end{array}$ & 13 \\
\hline \multicolumn{3}{|r|}{ No Alien Species } & $\begin{array}{l}\text { TBL5763 } \\
\text { TEV8511 } \\
\text { TMI8100 } \\
\text { TNE8840 } \\
\text { TSI10800 } \\
\text { TSU8511 } \\
\end{array}$ & $\begin{array}{l}\text { Old Black Oak Trail } \\
\text { Evelyn Lakes Trail } \\
\text { Mitchell Pass Trail } \\
\text { New Army Pass Trail } \\
\text { Siberian Outpost Trails } \\
\text { Sunset Lakes Trail } \\
\end{array}$ & None \\
\hline
\end{tabular}

Code: First letter: $\mathrm{C}=$ Campground, $\mathrm{D}=$ Development, $\mathrm{G}=$ Pasture/Meadow, $\mathrm{I}=$ Paved Road, $\mathrm{P}=$ Pack Station, $\mathrm{R}=$ Riparian, $\mathrm{T}=$ Trail, $\mathrm{U}=$ Dirt Road. Second and third letters: Unique site ID. Numerals: \#\#\#=Elevation (ft).

Sites in cluster 6 are uniquely rich in low elevation annual grasses and also possess species that are common at mid-elevations. Old Hidden Springs Trail at an elevation of $670 \mathrm{~m}$ $(2,190 \mathrm{ft})$ is rich in low elevation annual grasses as expected and there are also mid elevation forb species at seeps and at stream crossings. The small corral at South Fork Campground $(1,135$ $\mathrm{m} ; 3,730 \mathrm{ft}$ ) may be responsible for the large number of annual grasses found at the site. There is also a large number of annual grass species along the edges of Crystal Cave Parking Lot (1,490 m; 4,895 ft).

Cluster 7 is composed of sites that range from $1,370 \mathrm{~m}$ to $2,285 \mathrm{~m}(4,500 \mathrm{ft}$ to $7,500 \mathrm{ft})$ in elevation and are relatively poor in midelevation species and rich in annual grass species. Bromus tectorum and Vulpia myuros are constant annual grass species. The inclusion of Grant Grove Pack Station (1,955 m; 6,415 ft) in the low-species-richness cluster is an artifact of sampling difficulties. The survey of that site was conducted after stock animals were placed in the corrals and many of the plants were either eaten or trampled beyond recognition. Cluster 8, Trauger's Creek $(1,395 \mathrm{~m} ; 4,575 \mathrm{ft})$, is relatively rich in low-elevation species. However, neither Bromus tectorum nor Vulpia myuros are found at that site. That factor, in addition to the presence of mid-elevation species in seeps and at stream crossings, and the presence of Malus sylvestris, accounts for the site's distinct cluster.
Clusters 9,10 and 11 are notable for the presence of Poa pratensis. Sites in cluster 9, which range in elevation from $1,830 \mathrm{~m}$ to 2,590 $\mathrm{m}(6,000 \mathrm{ft}$ to $8,500 \mathrm{ft})$, are relatively low in forb richness, while Taraxicum officinale is characteristic of the sites in cluster 10 , which range in elevation from $2,135 \mathrm{~m}$ to $2,745 \mathrm{~m}$ $(7,000 \mathrm{ft}$ to $9,000 \mathrm{ft})$. Rumex acetosella and Spergularia rubra are characteristic of sites in cluster 11 , which range in elevation from 1,980 $\mathrm{m}$ to $2,285 \mathrm{~m}(6,500 \mathrm{ft}$ to $7,500 \mathrm{ft})$. Hart Loop Trail $(1,680 \mathrm{~m} ; 5,505 \mathrm{ft})$, a lower-elevation site, is included in this cluster because of the midand high-elevation species present at stream crossings and moist areas.

Clusters 12 and 13 are relatively rich in mid- and high-elevation forb species. The sites in cluster 12 ranges in elevation from $1,370 \mathrm{~m}$ to $2,440 \mathrm{~m}$ $(4,500 \mathrm{ft}$ to $8,000 \mathrm{ft})$. The low elevation Shepherd Saddle Road site is the only exception, and it appears to be rich in mid- and upperelevation forb species due to its proximity to Ash Mountain Corrals, Ash Mountain Shooting Range and Sycamore Creek. The sites in cluster 13 are at an elevation of $1,675 \mathrm{~m}(5,500 \mathrm{ft})$ and include the adjacent Oriole Lake Dirt Road and Oriole Lake Meadow sites in addition to Mineral King Dirt Road. The forb species at these sites are species that are typically dispersed in the dung of stock animals. Trespassing cattle from a nearby inholding graze the sites near Oriole Lake, and the Mineral King Dirt Road site is adjacent to the Mineral King Pack Station. 
Nearly all of the sites where no alien species were found are above $2,440 \mathrm{~m}(8,000 \mathrm{ft})$. The exception is Old Black Oak Trail at $1,755 \mathrm{~m}$ $(5,765 \mathrm{ft})$, a trail that has not been maintained for years. It is not clear why there are no alien species present at the other five sites as Poa pratensis and Taraxicum officinale are present along the Rae Lakes Loop Trail to elevations of $2,865 \mathrm{~m}(9,400 \mathrm{ft})$ and $2,990 \mathrm{~m}(9,800 \mathrm{ft})$ respectively.

\section{Yosemite National Park}

\section{Survey and Quadrat Data Collection}

1998 Field Methods - During the summer of 1998, field crews began sampling three patch types (campgrounds, developments, and corrals) and two corridor types (trails and roads). Alien species presence and cover estimates of alien and native species were obtained from all patch types. While presence/absence data were recorded for each corridor type, cover along trails and roads were not estimated because the distribution of nonnative plants along these linear landscape features was very patchy.

To conduct a survey, field crews compiled a complete list of plants in the study site. After making the list, the field crew placed each species into distribution classes and estimated the abundance of species on a log scale $(0-10$, $11-100, \quad 101-1000, \quad 1001-10,000,>10,000)$. Additionally, the distribution of each alien species was characterized as scattered individuals, scattered clumps of individuals, large clumps of many individuals, or widespread throughout the area. Trail and road surveys sometimes continued for several kilometers and species presence data were recorded in $1 \mathrm{~km}$ segments along the length of each survey.

A baseline transect was established along one edge of each patch and a random number table was used to randomly place sampling transects perpendicularly along the length of the baseline transect. Quadrats $\left(1-\mathrm{m}^{2}\right)$ were placed randomly along the sampling transects until thirty quadrats had been sampled. When thirty quadrats were sampled before the end of a sampling transect, the remainder of the sampling transect was also sampled to avoid biasing the data toward the beginning of the transect. In each quadrat, the cover of nonnative and native plant species was estimated to the nearest one percent. The cover of a particular species could not exceed 100 percent, but the total of all species in the quadrat frequently exceeded 100 percent. Additionally, a natural vegetation control site was established in undisturbed vegetation $50 \mathrm{~m}$ from five of the campground sites.

As was the case in Sequoia-Kings Canyon National Parks, the sample sites frequently contained areas such as parking lots or tent pads that were inappropriate for sampling, so quadrats had to pass rejection criteria before field crews sampled them. Randomly placed quadrats were rejected if more than 50 percent of the cover was incapable of supporting plant life (pavement, dirt roads, large boulders and trampled areas within $1 \mathrm{~m}$ of a structure). Areas where alien species are deliberately cultivated (lawns, flower pots, gardens) also were rejected. If the crews rejected several quadrats, they added additional transects until 30 quadrats were sampled. In areas that were sampled for cover, the canopy cover of shrubs and trees was also recorded. Shrub cover along the length of transects was measured using the line intercept method. Tree canopy cover was estimated using GRS brand densiometers at 100 regularly distributed points along the same transect. The quadrat sampling data were analyzed for exotic species richness and are included in the richness by elevation figures below.

1999 Field Methods - The survey crews measured the distribution of alien species in three types of patches (campgrounds, developments, corrals) and two types of corridors (trails and roads). Ten 50 by $2 \mathrm{~m}$ transects were randomly placed in each patch by establishing a baseline transect along one border known as a patch length (fig. 3a). The width of the target area was measured as a line perpendicular to the length, and a second baseline transect was established along the width border. Sampling transects were placed randomly along the two baseline axes. Whenever a sampling transect reached the boundary of a disturbed area or structure, the remainder of its sampling length was continued at the same position on the first axis and from 
the 0 position of the second axis (fig. 3a). At 10 $\mathrm{m}$ intervals beginning at meter $0,2 \mathrm{~m} \mathrm{x} 1 \mathrm{~m}$ quadrats were placed with the $2 \mathrm{~m}$ axis perpendicular to the sampling transect (fig. $3 b$ ). The cover of individual alien species and the total cover of all native species were estimated in each quadrat. The total numbers of alien and native species present in each sampling transect were also recorded. Canopy cover was measured every $5 \mathrm{~m}$ along each sampling transect using the point-intercept method with a GRS brand densiometer. Because some alien species did not fall within the sampling transects, the entire sampling area was surveyed to compile a complete list of all alien species present. Areas with high densities of buildings or very few plants were not sampled, but surveyed only. The abundance of species in each patch was estimated on a log scale after the patch was surveyed.

Trails in Yosemite were sampled based on levels of use by hikers and recreational stock. The Yosemite National Park Wilderness Office supplied data on the number of backpacking wilderness permits issued on each trail, and the trails were grouped into three categories: low use (0-50 people/year), moderate use (51-1100 people/year) and high use (1101-6900 people/year). Seven trails were randomly selected for sampling from each use category. The Wilderness Office also supplied data on the number of stock using the trails in categories of low (3-10/day), medium (11-25/day), and high $(26+$ /day). The concession stables provided route information for their daily rides in Yosemite Valley. Stock are only allowed on certain trails, and all trails open to stock use were sampled. The high use backpacking permit category contained the fewest number of trails, and most of these popular trails also received medium-high stock use. By comparison, low use backpacking permit trails had no stock use. No records were available for day-use by private stock parties on trails, so Mirror Lake Pack Trail and Yosemite Falls Trail had higher stock-use levels than indicated by the Wilderness Office data. Therefore, those trails were placed in the next higher stock-use category. At each trailhead the survey crews placed the first of ten $50 \mathrm{~m}$ by $2 \mathrm{~m}$ transects on the right side of and parallel to the trail, one meter from the tread of the trail.
Subsequent transects were placed on alternating sides of the trail and were begun across from the end of the previous transect. Transects were sampled using the same methods as were used to sample patches. After sampling within the transects, the field crews walked $3 \mathrm{~km}$ from the trailhead, recording all alien species that occurred within $2 \mathrm{~m}$ of the trail in each kilometer. Abundances of alien species were

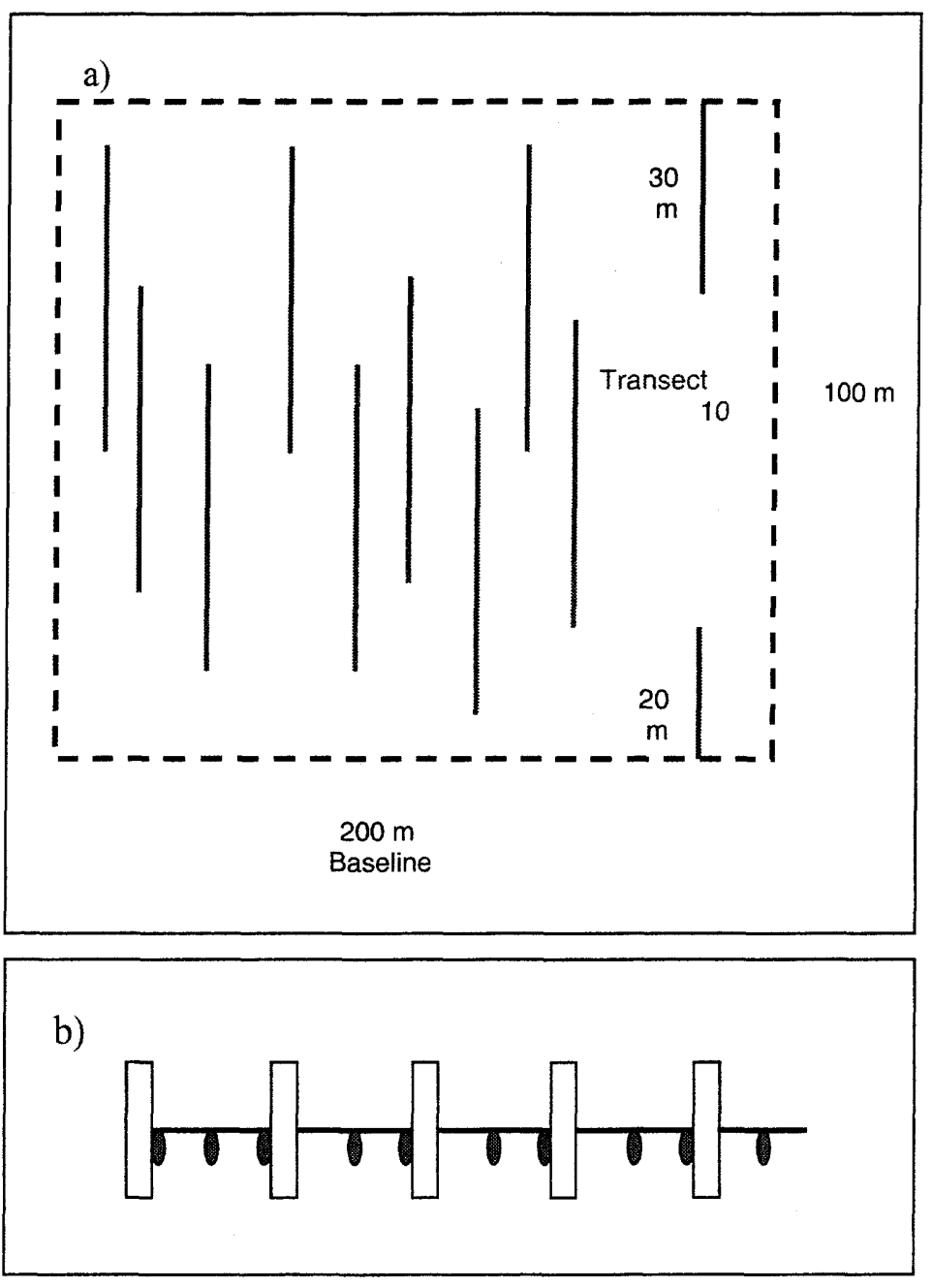

Figure 3. (a) Arrangement of 1999 transects in Yosemite National Park in campgrounds, developments and corrals that were sampled for alien species. Two dimensions of the sample site were measured, and the transects were arranged randomly along the two axes. When a transect ran outside of the sample area, as in Transect 10, it was continued at the same position on the first axis and from the 0 position of the second axis. (b) Sampling along $50 \mathrm{~m}$ transects. 1 by $2 \mathrm{~m}$ quadrats (rectangles) were placed every $10 \mathrm{~m}$, and canopy cover was sampled every $5 \mathrm{~m}$ (black points). 
estimated in each trail segment on a log scale. Data from the quadrat-based sampling revealed little in the way of patterns among site types. However, results from the quadrat data are included in the richness-by-elevation figures and tables.

Roads were selected for sampling based on an elevational gradient. All roads in the park were categorized in $305 \mathrm{~m}(1,000 \mathrm{ft})$ intervals between $915 \mathrm{~m}(3,000 \mathrm{ft})$ and 2,440 $\mathrm{m}(8,000 \mathrm{ft})$, and $1-\mathrm{km}$ segments of road were mapped within the intervals. Five segments within each interval were randomly selected for sampling. Field crews walked both sides of the road within the selected kilometer segments and recorded all alien species within $3 \mathrm{~m}$ of the road shoulder. Abundances of alien species were estimated in each road segment on a log scale. Coordinate locations for mapping survey areas and corridor segments were obtained from either a PLGRtype global positioning device or directly from USGS 7.5' quadrangles. The Jepson Manual: Higher Plants of California (Hickman 1993) was used to determine which plant species were not indigenous to the park.

\section{General Pattern}

The total number of alien species found in Yosemite was 123. Species richness varied among $1 \mathrm{~km}$ road sections from 1 to 31 , among $3 \mathrm{~km}$ trail segments from 1 to 26 and among corral/stable areas from 2 to 33 (table 2). There was a range in species richness from 1 to 56 among 19 developments and a range in species richness from 1 to 57 among 19 campgrounds. A total of 99 different species were found among developments and 68 different species among campgrounds. Species richness ranged from 52 to 62 for all roads, all trails or all corral/stable areas combined.

\section{Decline of Alien Species Richness with Increasing Elevation}

All sites - As was found for Sequoia-Kings Canyon National Parks, graphs of site alien species richness against site elevation indicate that alien species richness is strongly negatively correlated with elevation when all sites are pooled (fig. 4a). This negative correlation is evident for each of the five site types when the graphs are restricted to particular site types (fig. 4b-f). Additionally, the graph of all sites suggests that the factors controlling alien species richness change at an elevation of approximately $2,135 \mathrm{~m}(7,000 \mathrm{ft})$. The graph also suggests that the factors are different at elevations below $1,525 \mathrm{~m}(5,000 \mathrm{ft})$, but this pattern could be due to the large sampling effort at $1,220 \mathrm{~m}(4,000 \mathrm{ft})$ and the gap in target sites between $610 \mathrm{~m}(2,000$ $\mathrm{ft})$ and $1,220 \mathrm{~m}(4,000 \mathrm{ft})$.

Campgrounds/Camps - Alien species richness in campgrounds clearly is negatively correlated with elevation (fig. 4b). Additionally, the amount and type of use and site history apparently affect alien species richness in campgrounds and camps at an elevation of approximately $1,220 \mathrm{~m}(4,000 \mathrm{ft})$. The combined results of the 1998 and 1999 surveys recorded 56 alien species at Lower River Campground $(1,175 \mathrm{~m} ; 3,860 \mathrm{ft})$, which was closed after it flooded in 1997. This site had the largest number of alien species of any site surveyed in Yosemite and had 15 more alien species than Yosemite Lodge, which possessed the second highest alien species richness in Yosemite Valley. The high species richness at Lower River Campground could be due to a flush of germination from the soil seed bank, local seed dispersal, long distance seed dispersal, reduced mortality due to the elimination of trampling by campers and the longer two-year sampling period. Four high use campgrounds [Wawona $(1,200 \mathrm{~m} ; 3,930 \mathrm{ft})$ with 24 species, North Pines $(1,240 \mathrm{~m} ; 4,065 \mathrm{ft})$ with 24 species, Lower Pines $(1,210 \mathrm{~m} ; 3,970 \mathrm{ft})$ with 21 species, and Upper Pines $(1,205 \mathrm{~m} ; 3,950 \mathrm{ft})$ with 21 species] constitute the group of active campgrounds with the highest alien species richness. The three walk-in campgrounds [Hetch Hetchy $(1,250 \mathrm{~m} ; 4,100 \mathrm{ft})$ with 17 species, Backpackers $(1,225 \mathrm{~m} ; 4,020 \mathrm{ft})$ with 11 species, and Sunnyside $(1,225 \mathrm{~m} ; 4,020 \mathrm{ft})$ 
Table 2. Alien plant species richness by survey type and by site, Yosemite National Park

\begin{tabular}{|c|c|c|c|c|c|}
\hline \multicolumn{3}{|c|}{ Road Species Richness Summary - by Road Section } & \multicolumn{3}{|c|}{ Road Species Richness Summary - by Richness levels } \\
\hline & & Alien & & & $\begin{array}{l}\text { Alien } \\
\text { Sneces }\end{array}$ \\
\hline Road & Elevation (ft) & Species Richness & Road & Elevation (ft) & Species Richness \\
\hline Big Oak Flat Road & 4661 & 16 & Northside Drive & 3959 & 31 \\
\hline Big Oak Flat Road & 4946 & 18 & Southside Drive & 3958 & 26 \\
\hline Big Oak Flat Road & 5272 & 16 & Yosemite West & 5969 & 22 \\
\hline Big Oak Flat Road & 5902 & 8 & Wawona Road & 3964 & 19 \\
\hline Glacier Point Road & 6179 & 1 & El Portal Road & 3842 & 18 \\
\hline Glacier Point Road & 6440 & 4 & Big Oak Flat Road & 4946 & 18 \\
\hline Glacier Point Road & 7176 & 1 & Big Oak Flat Road & 4661 & 16 \\
\hline Glacier Point Road & 7704 & 1 & Big Oak Flat Road & 5272 & 16 \\
\hline Hetch Hetchy Road & 5505 & 9 & Wawona Road & 6051 & 16 \\
\hline El Portal Road & 3842 & 18 & Wawona Road & 5142 & 15 \\
\hline Northside Drive & 3959 & 31 & Wawona Road & 6040 & 14 \\
\hline Southside Drive & 3958 & 26 & Hetch Hetchy Road & 5505 & 9 \\
\hline Tioga Road & 6254 & 7 & Big Oak Flat Road & 5902 & 8 \\
\hline Tioga Road & 7143 & 2 & Tioga Road & 6254 & 7 \\
\hline Tioga Road & 7981 & 2 & Glacier Point Road & 6440 & 4 \\
\hline Tioga Road & 8127 & 2 & Tioga Road & 8472 & 4 \\
\hline Tioga Road & 8150 & 2 & Tioga Road & 7143 & 2 \\
\hline Tioga Road & 8472 & 4 & Tioga Road & 7981 & 2 \\
\hline Tioga Road & 8674 & 1 & Tioga Road & 8127 & 2 \\
\hline Wawona Road & 3964 & 19 & Tioga Road & 8150 & 2 \\
\hline Wawona Road & 5142 & 15 & Glacier Point Road & 6179 & 1 \\
\hline Wawona Road & 6040 & 14 & Glacier Point Road & 7176 & 1 \\
\hline Wawona Road & 6051 & 16 & Glacier Point Road & 7704 & 1 \\
\hline Yosemite West & 5969 & 22 & Tioga Road & 8674 & 1 \\
\hline Roadside Species & & Total $=\mathbf{5 7}$ & Roadside Species & & Total $=\mathbf{5 7}$ \\
\hline \multicolumn{3}{|c|}{ Trail Species Richness Summary - by Trail } & \multicolumn{3}{|c|}{ Trail Species Richness Summary - by Richness Levels } \\
\hline & & Alien & & & Alien \\
\hline Trail & Elevation (ft) & Species Richness & Trail & Elevation (ft) & Species Richness \\
\hline Alder Creek & 4557 & 7 & Meadow Loop & 4053 & 32 \\
\hline Bridalveil Creek & 6969 & 2 & Yosemite Loop & 3972 & 26 \\
\hline Bridalveil Falls & 4035 & 7 & Mirror Lake Pack & 3931 & 14 \\
\hline Bridalveil-Inspiration Pt. & 4036 & 6 & Mariposa Grove & 5256 & 13 \\
\hline Chilnaulna Falls & 4417 & 6 & Happy Isles & 4959 & 12 \\
\hline Four Mile & 3960 & 11 & Four Mile & 3960 & 11 \\
\hline Glen Aulin & 8686 & 3 & Old Big Oak Flat Rd. & 4770 & 9 \\
\hline Happy Isles & 4959 & 12 & Snow Creek & 4100 & 9 \\
\hline Harden Lake & 7821 & 4 & Yosemite Falls & 4015 & 8 \\
\hline Inspiration Pt. & 4381 & 4 & Alder Creek & 4557 & 7 \\
\hline John Muir-Tuolumne & 8675 & 2 & Bridalveil Falls & 4035 & 7 \\
\hline Lukens Lake & 7886 & 2 & Bridalveil-Inspiration Pt. & 4036 & 6 \\
\hline Mariposa Grove & 5256 & 13 & Chilnaulna Falls & 4417 & 6 \\
\hline Meadow Loop & 4053 & 32 & Inspiration Pt. & 4381 & 4 \\
\hline Merced Grove & 4771 & 2 & Harden Lake & 7821 & 4 \\
\hline Mirror Lake Pack & 3931 & 14 & Panorama & 7243 & 4 \\
\hline Old Big Oak Flat Rd. & 4770 & 9 & Glen Aulin & 8686 & 3 \\
\hline Panorama & 7243 & 4 & Tamarack Creek & 6339 & 3 \\
\hline Porcupine Creek & 8100 & 1 & Bridalveil Creek & 6969 & 2 \\
\hline Snow Creek & 4100 & 9 & John Muir-Tuolumne & 8675 & 2 \\
\hline Taft Point & 7729 & 1 & Lukens Lake & 7886 & 2 \\
\hline Tamarack Creek & 6339 & 3 & Merced Grove & 4771 & 2 \\
\hline Yosemite Falls & 4015 & 8 & Young Lakes & 8622 & 2 \\
\hline Yosemite Loop & 3972 & 26 & Porcupine Creek & 8100 & 1 \\
\hline Young Lakes & 8622 & 2 & Taft Point & 7729 & 1 \\
\hline Trailside Species & & Total $=51$ & Trailside Species & & Total $=51$ \\
\hline
\end{tabular}


Table 2. Alien plant species richness by survey type and by site, Yosemite National Park--Continued

\begin{tabular}{|c|c|c|c|c|c|}
\hline \multicolumn{3}{|c|}{ Corral Species Richness Summary - by Site } & \multicolumn{3}{|c|}{ Corral Species Richness Summary - by Richness level } \\
\hline Corral/Stable Site & Elevation (ft) & $\begin{array}{l}\text { Alien Species } \\
\text { Richness }\end{array}$ & Corral/Stable Site & Elevation (ft) & $\begin{array}{c}\text { Alien Species } \\
\text { Richness }\end{array}$ \\
\hline Concession Stables(YV) & 4000 & 33 & McCauley Ranch & 4093 & 33 \\
\hline Glen Aulin High Sierra Camp & 7832 & 2 & Concession Stables(YV) & 4000 & 33 \\
\hline Government Stables (YV) & 4039 & 13 & Hetch Hetchy Corral & 3960 & 32 \\
\hline Government Corrals (Tuol) & 8695 & 2 & Wawona Stables & 4001 & 20 \\
\hline Harden Lake Corral & 7496 & 8 & Government Stables (YV) & 4039 & 13 \\
\hline Hetch Hetchy Corral & 3960 & 32 & White Wolf Corral & 7967 & 10 \\
\hline McCauley Ranch & 4093 & 33 & Tuolumne Stables & 8632 & 8 \\
\hline Tuolumne Stables & 8632 & 8 & Harden Lake Corral & 7496 & 8 \\
\hline Wawona Stables & 4001 & 20 & Government Corrals (Tuol) & 8695 & 2 \\
\hline White Wolf Corral & 7967 & 10 & Glen Aulin High Sierra Camp & 7832 & 2 \\
\hline Species of Corrals/Stables & & Total $=63$ & Species of Corrals/Stables & & Total $=63$ \\
\hline
\end{tabular}

with 4 species] possessed the lowest alien species richness. There were very few alien species at campgrounds or camps above an elevation of $1,830 \mathrm{~m}(6,000 \mathrm{ft})$, and no alien species were discovered in the control quadrats that were sampled outside the boundaries of five campgrounds. For Wawona Campground (see arrow in fig. 4b), this is a remarkable finding as the site lies within an elevational range that is highly invaded by alien species. The site notes indicate that the control site was located $50 \mathrm{~m}$ north of the campground in an open canopy Pinus ponderosa (ponderosa pine) forest with Calocedrus decurrens (incense-cedar) and scattered Quercus kelloggii (California black oak) and a ground cover of Chamaebatia foliolosa (mountain misery).

Roads - The strong negative correlation between alien species richness and elevation is evident from the survey of roadsides (fig. 4c).

Alien species richness also appears to be affected by site-specific characteristics. For example, the Yosemite Valley roads [Northside Drive adjacent to El Capitan Meadow and Southside Drive, 1,205 m (3,960 ft)] (YV symbol) may be rich in alien species because they contain both mesic and disturbed habitats while the Yosemite West $(1,820 \mathrm{~m} ; 5,970 \mathrm{ft})$ (YW symbol) site may be species rich because it is a $3 \mathrm{~km}$ segment through a developed section of Ponderosa Way. Alien species richness declined dramatically at elevations above 2,135 m (7,000 ft). All road corridor sites below 1,525 $\mathrm{m}(5,000 \mathrm{ft})$ were surveyed in 1998 , road sites between $1,525 \mathrm{~m}(5,000 \mathrm{ft})$ and $1,830 \mathrm{~m}(6,000$ $\mathrm{ft}$ ) were surveyed in 1998 and 1999, and road 18 corridors above $1,830 \mathrm{~m}(6,000 \mathrm{ft})$ were surveyed in 1999. Therefore, differences between years may have been responsible for a minor part of the elevational effect. Additionally, there were no road surveys conducted at elevations below $1,220 \mathrm{~m}(4,000$ $\mathrm{ft}$ ). Appendix D contains a complete alien species list for all surveyed road segments.

Trails - The negative correlation between alien species richness and elevation is evident in the graph of the trail data (fig. 4d). However, the strength of the negative correlation is much reduced if the heavily used Meadow Loop Trail $(1,235 \mathrm{~m} ; 4,055 \mathrm{ft})$ with 31 species and Yosemite Loop Trail $(1,210 \mathrm{~m} ; 3,970 \mathrm{ft})$ with 25 species are excluded from the graph. A summary of the 1998 survey data for trails is presented in table 3, a summary of the 1999 quadrat and survey data is presented in table 4 , and a list of all alien species discovered along trails is given in Appendix E. Bromus tectorum is clearly the most common alien species along trails in the park. While the level of trail usage appears to be important, it is not clear if alien species richness is correlated with the use level of a trail by either hikers or pack animals or is due to the combined effect of both uses (tables 3 and 4).

Developments - There is a very strong negative correlation between alien species richness and elevation among developments (fig. 4e). Additionally, length of growing season may also be important along with site history (such as the amount of disturbance, the amount of seed dispersal, or both). For example, the points plotted at an elevation of approximately $1,220 \mathrm{~m}$ 

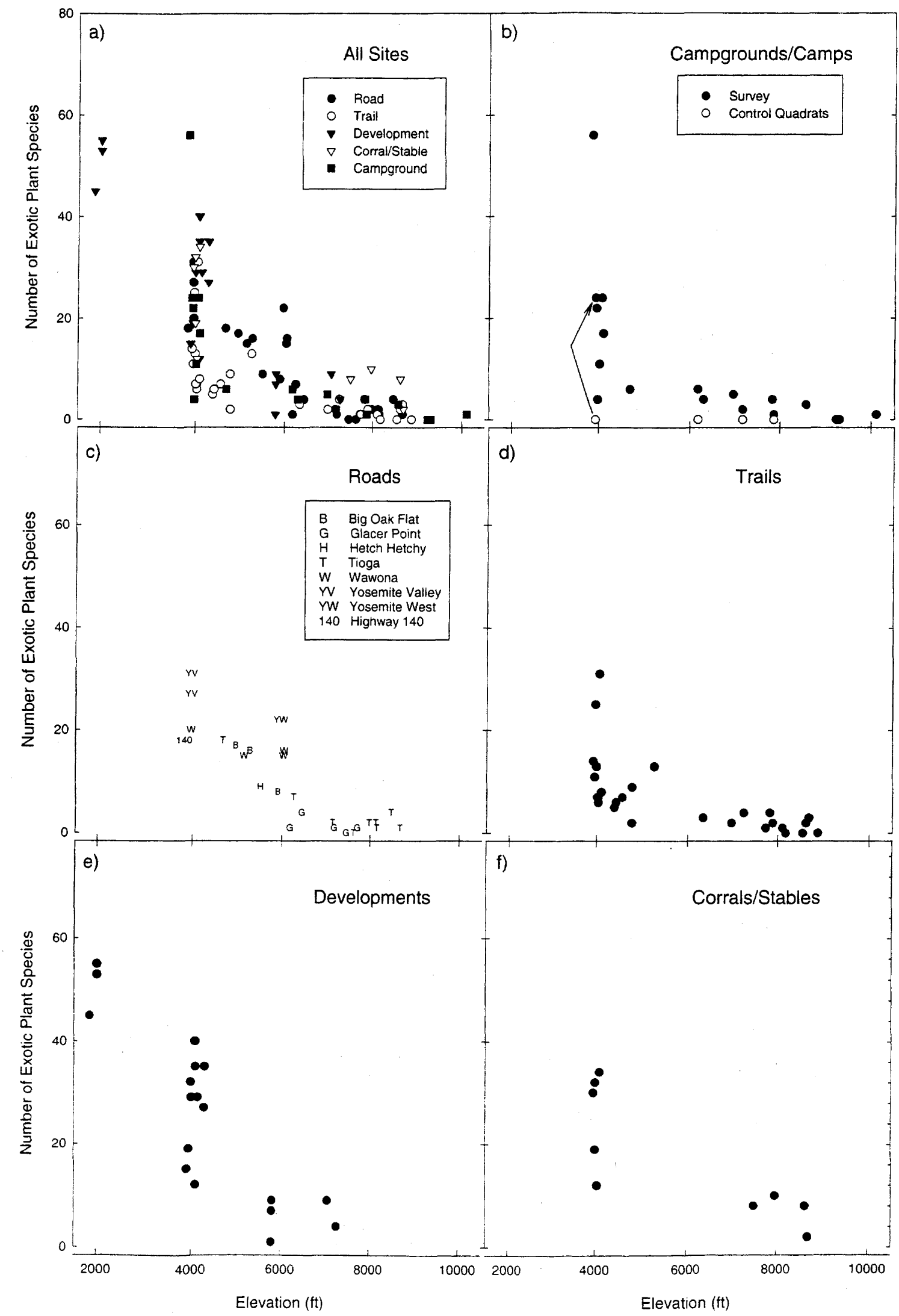

Figure 4. Yosemite National Park alien (exotic) species richness by elevation. 
Table 3. Yosemite National Park 1998 trail survey data

\begin{tabular}{lccccccc} 
Trail & $\begin{array}{c}\text { Elevation } \\
(\mathrm{ft})\end{array}$ & Richness & Abund. & Dist. & Human & Pack & Most Abundant Species \\
\hline Four Mile & 3960 & 11 & $1-4$ & $1-2$ & High & Low & B. tectorum, Rumex acetosella \\
Bridalveil Falls & 4035 & 7 & $2-4$ & $1-3$ & High & 0 & B. tectorum, Poa pratensis \\
Bridalveil Falls/Inspiration Pt. & 4036 & 6 & $1-3$ & $1-2$ & Low & Low & B. tectorum, Vulpia myuros \\
Inspiration Point & 4381 & 5 & $2-5$ & $1-4$ & Mod. & Low & B. tectorum. Silene latifolia \\
Mariposa Grove & 5256 & 13 & $1-5$ & $1-3$ & Low & High & B. tectorum, P. pratensis, \\
Panorama & 7243 & 4 & $2-4$ & 2 & Mod. & Low & B. tectorum, Spergularia rubra \\
\hline
\end{tabular}

Notes: 1) Elevation is trailhead elevation in feet; 2) Richness is alien species richness; 3) Abund. is range of abundance with categories, 1 is $0-10,2$ is $11-100,3$ is $101-1,000,4$ is $1,001-10,000,5$ is $>10,000 ; 4)$ Dist. is the range of distributions of alien species where 1 is scattered individuals, 2 is scattered clumps of individuals, 3 is large clumps of many individuals, and 4 is widespread throughout the area; 5) Human indicates human use level, Low ( 0 - 50 people per year), Moderate (51-1,100 people per year), and High (1,101-6,900 people per year); 6) Pack indicates pack animal use level, Low (3-10 animals per day), Moderate (11-25 animals per day, and High (>26 animals per day); 7) Lists the two most common alien species with abundances greater than category 2.

$(4,000 \mathrm{ft})$ comprise two groups. The species-rich sites (Foresta, Wawona, Yosemite Village, Yosemite Lodge, The Ahwahnee Hotel) have either broad westerly exposure (former two) or southerly exposure (latter three) which lengthen the growing season. The relatively species-poor sites (Curry Village, Housekeeping, Mirror Lake) are in narrow, heavily shaded sections of Yosemite Valley (due to canyon walls) with north to northwest exposures.

Corrals/Stables - The number of alien species found at corrals and stables is negatively correlated with elevation (fig. 4f) and also appears to be influenced by local factors. Three corral/stable sites with the largest number of alien species were, in descending richness, McCauley Ranch, Concession Stables (Yosemite Valley) and Hetch Hetchy Corral. Each is very close to $1,220 \mathrm{~m}(4,000 \mathrm{ft})$. The sampling at Hetch Hetchy Corral extended through an annual grassland pasture, and the alien species present were typical species found in annual grassland vegetation. However, McCauley Ranch and Concession Stables (Yosemite Valley) possessed a diverse assemblage of annual grassland species, forage species and forage weeds and meadow species. The habitats at both sites were more diverse than the Hetch Hetchy Corral site as the Concession Stables (Yosemite Valle's) survey included Lamon
Meadow, and the McCauley Ranch survey included a marshy area. It is not clear why Wawona Stables, the next most diverse site, had relatively fewer species as the survey of that site also included an adjacent meadow. Appendix $F$ contains a complete alien species list for all surveyed corrals and stables.

The correlations between the alien species floras of corrals and stables and the alien species floras of the trails that lead from them are complex. The alien species present along the low elevation Mirror Lake Pack Trail (1,200 m; 3,930 ft) that begins at the Concession Stables (Yosemite Valley) all occurred in the first $500 \mathrm{~m}$ of the trail (table 3). The field description of the trail indicates that it runs through a shady stand of Pinus ponderosa and Calocedrus decurrens with little ground cover. The fact that the only alien species along the trail were present at the beginning of the trail suggests that aliens are not spreading from the Concession Stables (Yosemite Valley).

However, the species occurring along Snow Creek Trail, which runs through a stand of Quercus chrysolepis (canyon live oak) from the point where it connects with Mirror Lake Pack Trail, suggests that alien species are being dispersed by pack animals. 
Table 4. Yosemite National Park 1999 trail transect and survey data

\begin{tabular}{|c|c|c|c|c|c|c|c|}
\hline Trail & $\begin{array}{c}\text { Elevation } \\
(\mathrm{ft})\end{array}$ & Richness & Alien & Native & Human & Pack & Common Species \\
\hline Mirror Lake Pack & 3931 & $13 / 15$ & $0-5 / \mathrm{H}^{* *}$ & $0-5 / \mathrm{H}$ & High & High & Bromus tectorum, Trifolium repens \\
\hline Yosemite Loop & 3972 & $21 / 25$ & $0-5 / \mathrm{L}$ & $0-6 / \mathrm{L}$ & High & High & Many species \\
\hline Happy Isles & 4000 & $8 / 13$ & $0-4 / \mathrm{H}^{* *}$ & $0-5 / \mathrm{H}$ & High & High & Marubium vulgare \\
\hline Yosemite Falls & 4015 & $1 / 9$ & $0-1 / \mathrm{H}$ & $0-4 / \mathrm{H}$ & High & Low & None \\
\hline Meadow Loop, Wawona & 4053 & $14 / 31$ & $0-4 / \mathrm{L}$ & $0-4 / \mathrm{L}$ & Mod. & Mod. & Rumex acetosella, Vulpia myuros \\
\hline Snow Creek & 4100 & $2 / 8$ & $0-1 / \mathrm{H}$ & $0-3 / \mathrm{H}$ & Low & Low & None \\
\hline Chilnualna Falls & 4417 & $2 / 6$ & $0-1 / \mathrm{H}$ & $0-5 / \mathrm{L}$ & Low & Mod. & None \\
\hline Alder Creek & 4557 & $4 / 7$ & $0-5 / \mathrm{H}$ & $0-4 / \mathrm{H}$ & Low & High & V. myuros, B. tectorum \\
\hline Merced Grove & 4770 & $0 / 2$ & 0 & $0-6 / \mathrm{H}$ & Low & Low & None \\
\hline Old Big Oak Flat & 4770 & $5 / 9$ & $0-4 / \mathrm{H}$ & $1-6 / 0$ & Mod. & 0 & B. tectorum, V. myuros \\
\hline Tamarack Creek & 6339 & $1 / 3$ & $1 / \mathrm{H}$ & $0-4 / \mathrm{H}$ & Low & 0 & None \\
\hline Bridalveil Creek & 6969 & $1 / 2$ & 0 & $0-6 / 0$ & Low & Mod. & None \\
\hline Taft Point & 7729 & $0 / 1$ & 0 & $0-5 / L$ & Mod. & 0 & None \\
\hline Harden Lake & 7821 & $1 / 4$ & $1-2 / \mathrm{H}$ & $0-5 / \mathrm{L}$ & Low & Low & None \\
\hline Lukens Lake & 7886 & $2 / 2$ & $0-1 / \mathrm{H}^{* *}$ & $0-5 / 0$ & Low & High & None \\
\hline Porcupine Creek & 8100 & $0 / 1$ & 0 & $0-4 / \mathrm{H}$ & Mod. & Low & None \\
\hline Sunrise High Sierra Camp & 8174 & $0 / 0$ & 0 & $0-6 / \mathrm{L}$ & High & Mod. & None \\
\hline Cathedral Lake & 8552 & $0 / 0$ & 0 & $0-5 / \mathrm{L}$ & High & High & None \\
\hline Young Lake & 8622 & $2 / 2$ & $1 / \mathrm{H}$ & $0-6 / 0$ & Mod. & High & None \\
\hline John Muir Trail, Tuolumne & 8675 & $2 / 2$ & $1-2 / \mathrm{H}$ & $1-6 / L$ & Mod. & High & None \\
\hline Glen Aulin & 8686 & $1 / 3$ & $1 / \mathrm{H}$ & $0-6 / 0$ & High & High & None \\
\hline May Lake & 8881 & $0 / 0$ & 0 & $0-6 / \mathrm{L}$ & High & Mod. & None \\
\hline
\end{tabular}

Notes: 1) Elevation is trail head elevation in feet; 2) Richness is alien species richness for Transect/Survey sampling methods respectively; 3) Alien is range of cover in individual quadrats and patchiness among quadrats respectively. Cover categories for the lowest and highest value for any individual species are: $0=$ no cover; 1 is $<5 \% ; 2$ is $5-10 \% ; 3$ is $11-30 \% ; 4$ is $31-70 \%$; 5 is $71-90 \%$; and 6 is $91-100 \%$. Patchiness categories for the lowest and highest value for any individual species were determined as: 0 indicates $<10$ quadrats had 0 or $<5 \%$ cover for any species; $\mathrm{L}$ indicates that between 10 and 24 quadrats had 0 or $<5 \%$ cover for any species; and $\mathrm{H}$ indicates that 25 or more quadrats had 0 or $<5 \%$ cover for any species. $* *$, indicates that alien species were found only in the first 2 transects $(100 \mathrm{~m}) ; 4)$ Native values represent cover in individual quadrats/patchiness of all native species combined and the categories are the same as Alien; 5) Human indicates human use level, Low ( 0 - 50 people per year), Moderate (51-1100 people per year), and High (1101-6900 people per year) ; 6) Pack indicates pack animal use level, Low (3-10 animals per day), Moderate (11-25 animals per day), and High ( $>26$ animals per day); 7) Common Species lists the 2 most common species with cover greater than category 2.

Three species that are commonly dispersed in horse dung: Aira caryophyllea, Bromus sterilis, Poa pratensis (silver European hairgrass, poverty brome, Kentucky bluegrass, respectively), and four species dispersed through stockyard activities are present along Snow Creek Trail (Appendix E and ESTA Species Microsoft ${ }^{\underline{B}}$ Access database file). White Wolf
Corral $(2,430 \mathrm{~m} ; 7,970 \mathrm{ft})$ is a potential source of the dung-dispersed species (Poa pratensis, Trifolium repens, Rumex acetosella) present at Harden Lake Corral $(2,285 \mathrm{~m} ; 7,495 \mathrm{ft})$. However, the site history at Harden Lake Corral includes nearby homesteading and pasturing of pack-stock animals for lengthy periods to support nonrecreational wilderness trips. It is 
interesting that only one of these species was discovered along Harden Lake Trail ( $R$. acetosella) and none along Lukens Lake Trail when both trails begin at White Wolf. This is despite the occurrence of Poa pratensis at higher elevations on the Young Lakes and Glen Aulin Trails. A similarly complex situation existed for the trails that begin near Tuolumne Concessions Stable, which also supported $P$. pratensis and $T$. repens. Both of those species were present along Glen Aulin Trail and also at Glen Aulin High Sierra Camp. Only $P$. pratensis was found along the Young Lakes Trail, and neither species was found along either the section of the John Muir Trail that leads toward the Vogelsang High Sierra Camp or at the camp itself. These inconsistent patterns may indicate that alien plant establishment along trails leading from higher-elevation corrals and stables have been sporadic and opportunistic.

\section{Similarity of Alien Species Composition Among Sites}

To compare and contrast species composition among sites, an exploratory cluster analysis of the sites included in the species-richness-byelevation figures was conducted using PC-ORD version 4 . The same procedures were followed as those used to analyze the Sequoia-Kings Canyon National Parks data (fig. 5). An ecological interpretation of the factors that significantly affected the clustering of the alien species is presented in table 5 . Note that the sites with no alien species have been added to the table as an unnumbered cluster. The coarsest division of the sites is due to sites with high alien species richness that are found at low-, mid-, and high-elevations versus sites with moderate to low species richness. The doublezero effect is even more pronounced in the Yosemite National Park analysis as the resemblance between pairs of sites increases consistently with elevation. The shorter the initial "legs" of the dendrogram in figure 5, the more closely the site pairs resemble each other. The next coarsest division among high-richness sites is between low-elevation sites $(610 \mathrm{~m}$; 2,000 ft) at Rancheria and Old El Portal and sites that are at an elevation of approximately $1,220 \mathrm{~m}(4,000 \mathrm{ft})$. For the moderate to lowrichness sites, the next coarsest division is between mid-elevation sites 1,220-2,135 m (4,000-7,000 ft) with mixtures of low-, mid-, and high-elevation species and higher-elevation sites $(1,830-3,050 \mathrm{~m} ; 6,000-10,000 \mathrm{ft})$ with mixtures of mid- and high-elevation species. The sites between 1,220 m (4,000 ft) and 2,135 m (7,000 $\mathrm{ft})$ can be divided into sites with a relatively high proportion of forb species and sites with a relatively high proportion of grass species.

Clusters 1 and 2 consist of high-richness sites with unique combinations of species at an elevation of approximately $1,220 \mathrm{~m}(4,000 \mathrm{ft})$. Cluster 1 sites are primarily in Yosemite Valley and appear to possess species characteristic of mesic habitats as well as species characteristic of disturbed habitats. Cluster 2 sites are primarily in Wawona and Foresta, and species adapted to mesic conditions appear to be less common at those sites. Cluster 3 consists of Yosemite Valley sites with Rubus discolor and a high proportion of alien perennial grasses. Cluster 4 sites are all low-elevation sites $(610 \mathrm{~m} ; 2,000 \mathrm{ft})$ located in Rancheria and El Portal. These three sites are rich in species characteristic of annual grassland vegetation as well as many other species.

Cluster 5 sites are typically mid-elevation trails (1,220-1,675 m; 4,000-5,500 ft) lined with Bromus tectorum and Vulpia myuros and dotted with low and mid elevation forb species (See Appendix E for trail species lists). Cluster 6 consists of mid-elevation sites $(1,830-2,135 \mathrm{~m}$; $6,000-7,000 \mathrm{ft}$ ) with a high proportion of mid elevation forb species that are adapted to disturbed areas. Some characteristic species are Spergularia rubra, Plantago major and Polygonum arenastrum (sand-spurrey, common plantain and common knotweed, respectively). Cluster 7 consists of mid-elevation sites $(1,220$ $1,830 \mathrm{~m} ; 4,000-6,000 \mathrm{ft}$ ) that are relatively rich in alien forb species. The ecological reason for the clustering of The Ahwahnee hotel and the Mirror Lake Pack Trail in this group is not clear except that they share several species in common with the other sites (Poa pratensis universally) and has a similar level of alien species diversity. Cluster 8 consists of midelevation sites $(1,220-1,525 \mathrm{~m} ; 4,000-5,000 \mathrm{ft})$ with a high proportion of grass species. 


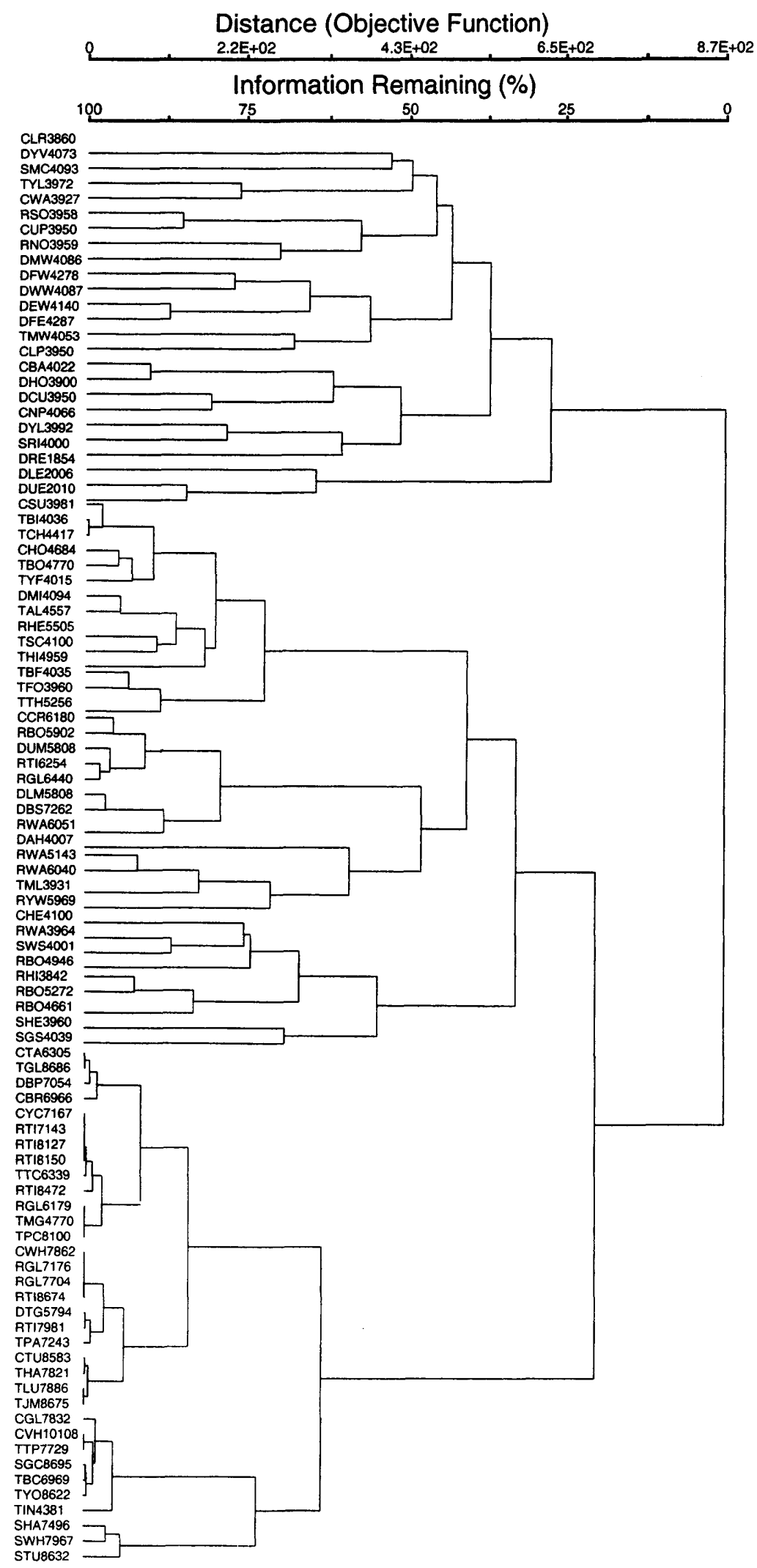

Figure 5. Yosemite National Park cluster analysis. 
Table 5. Interpretation of Yosemite National Park cluster analysis

\begin{tabular}{|c|c|c|c|c|c|c|}
\hline \multicolumn{4}{|c|}{ Cluster Characteristics } & Code & Site & Cluster \\
\hline \multirow{4}{*}{ 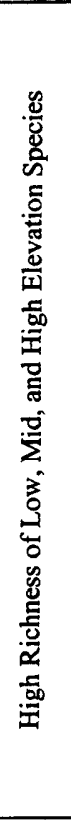 } & \multirow{3}{*}{ 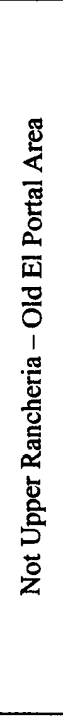 } & \multirow{2}{*}{ 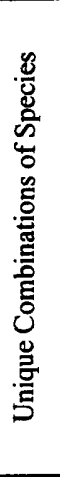 } & $\begin{array}{l}\text { Unique Combinations of } \\
\text { Species }\end{array}$ & $\begin{array}{l}\text { CLR3930 } \\
\text { DYV4073 } \\
\text { SMC4093 } \\
\text { TYL3972 } \\
\text { CWA3927 } \\
\text { RSO3958 } \\
\text { CUP3950 } \\
\text { RNO3959 } \\
\end{array}$ & $\begin{array}{l}\text { Lower River Campground } \\
\text { Yosemite Village } \\
\text { McCauley Ranch } \\
\text { Yosemite Loop Trail } \\
\text { Wawona Campground } \\
\text { Southside Drive } \\
\text { Upper Pines Campground } \\
\text { Northside Drive } \\
\end{array}$ & 1 \\
\hline & & & Wawona - Foresta Area & $\begin{array}{l}\text { DMW4086 } \\
\text { DFW4278 } \\
\text { DWW4087 } \\
\text { DEW4140 } \\
\text { DFE4287 } \\
\text { TMW4053 } \\
\end{array}$ & $\begin{array}{l}\text { Middle Wawona } \\
\text { Foresta West } \\
\text { West Wawona } \\
\text { East Wawona } \\
\text { Foresta East } \\
\text { Meadow Loop Trail, Wawona } \\
\end{array}$ & 2 \\
\hline & & & $\begin{array}{c}\text { Yosemite Valley } \\
\text { Perennial Grasses } \\
\text { and } \\
\text { Rubus discolor }\end{array}$ & $\begin{array}{l}\text { CLP3950 } \\
\text { CBA4022 } \\
\text { DHO3900 } \\
\text { DCU3950 } \\
\text { CNP4066 } \\
\text { DYL3992 } \\
\text { SRI4000 } \\
\end{array}$ & $\begin{array}{l}\text { Lower Pines Campground } \\
\text { Backpacker's Camp } \\
\text { Housekeeping } \\
\text { Curry Village } \\
\text { North Pines Campground } \\
\text { Yosemite Lodge } \\
\text { Concession Stables (YV) } \\
\end{array}$ & 3 \\
\hline & & er Ran & ia - Old El Portal Area & $\begin{array}{l}\text { DRE1854 } \\
\text { DLE2006 } \\
\text { DUE2010 } \\
\end{array}$ & $\begin{array}{l}\text { Upper Rancheria-El Portal } \\
\text { Lower Old El Portal } \\
\text { Upper Old El Portal }\end{array}$ & 4 \\
\hline & 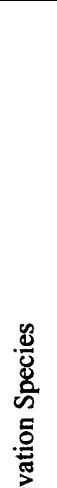 & 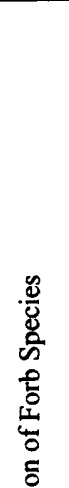 & $\begin{array}{l}\text { Bromus tectorum } \\
\text { and } \\
\text { Vulpia myuros } \\
\text { With Mixtures of Low and } \\
\text { Mid Elevation Species } \\
\text { Typically Trails }\end{array}$ & $\begin{array}{l}\text { CSU3981 } \\
\text { TBI4036 } \\
\text { TCH4417 } \\
\text { CHO4684 } \\
\text { TBO4770 } \\
\text { TYF4015 } \\
\text { DMI4094 } \\
\text { TAL4557 } \\
\text { RHE5505 } \\
\text { TSC4100 } \\
\text { THI4000 } \\
\text { TBF4035 } \\
\text { TFO3960 } \\
\text { TTH5256 } \\
\end{array}$ & $\begin{array}{l}\text { Sunnyside Campground } \\
\text { Bridalveil-Inspiration Pt. Trail } \\
\text { Chilnaulna Falls Trail } \\
\text { Hogdon Meadow Campground } \\
\text { Big Oak Flat Road Trail } \\
\text { Yosemite Falls Trail } \\
\text { Mirror Lake } \\
\text { Alder Creek Trail } \\
\text { Hetch Hetchy Road } \\
\text { Snow Creek Trail } \\
\text { Happy Isles Trail } \\
\text { Bridalveil Falls Trail } \\
\text { Four Mile Trail } \\
\text { Two Hour Trail } \\
\end{array}$ & 5 \\
\hline 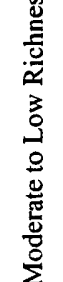 & 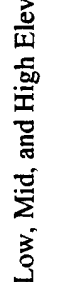 & 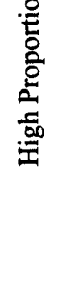 & $\begin{array}{c}\text { High Proportion } \\
\text { of } \\
\text { Mid Elevation } \\
\text { Forb Species }\end{array}$ & $\begin{array}{l}\text { CCR6180 } \\
\text { RBO5902 } \\
\text { DUM5808 } \\
\text { RTI6254 } \\
\text { RGL6440 } \\
\text { DLM5808 } \\
\text { DBS7262 } \\
\text { RWA6051 } \\
\end{array}$ & $\begin{array}{l}\text { Crane Flat Campground } \\
\text { Big Oak Flat Road (5902) } \\
\text { Upper Mariposa Grove } \\
\text { Tioga Road (6254) } \\
\text { Glacier Point Road (6440) } \\
\text { Lower Mariposa Grove } \\
\text { Badger Pass Ski Resort } \\
\text { Wawona Road (6051) } \\
\end{array}$ & 6 \\
\hline & 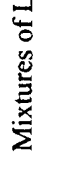 & & High Species Richness & $\begin{array}{l}\text { DAH4007 } \\
\text { RWA5143 } \\
\text { RWA6040 } \\
\text { TML3931 } \\
\text { RYW5969 } \\
\end{array}$ & $\begin{array}{l}\text { The Ahwahnee } \\
\text { Wawona Road (5143) } \\
\text { Wawona Road (6040) } \\
\text { Mirror Lake Pack Trail } \\
\text { Yosemite West Road } \\
\end{array}$ & 7 \\
\hline & & & roportion of Grass Species & $\begin{array}{l}\text { CHE4100 } \\
\text { RWA3964 } \\
\text { SWS4001 } \\
\text { RBO4946 } \\
\text { RHI3842 } \\
\text { RBO5272 } \\
\text { RBO4661 } \\
\text { SHE3960 } \\
\text { SGS4039 } \\
\end{array}$ & $\begin{array}{l}\text { Hetch Hetchy Backpacker's Camp } \\
\text { Wawona Road (3964) } \\
\text { Wawona Stables } \\
\text { Big Oak Flat Road (4946) } \\
\text { El Portal Road } \\
\text { Big Oak Flat Road (5272) } \\
\text { Big Oak Flat Road (4661) } \\
\text { Hetch Hetchy Corral } \\
\text { Government Stables } \\
\end{array}$ & 8 \\
\hline
\end{tabular}


Table 5. Interpretation of Yosemite National Park cluster analysis--Continued

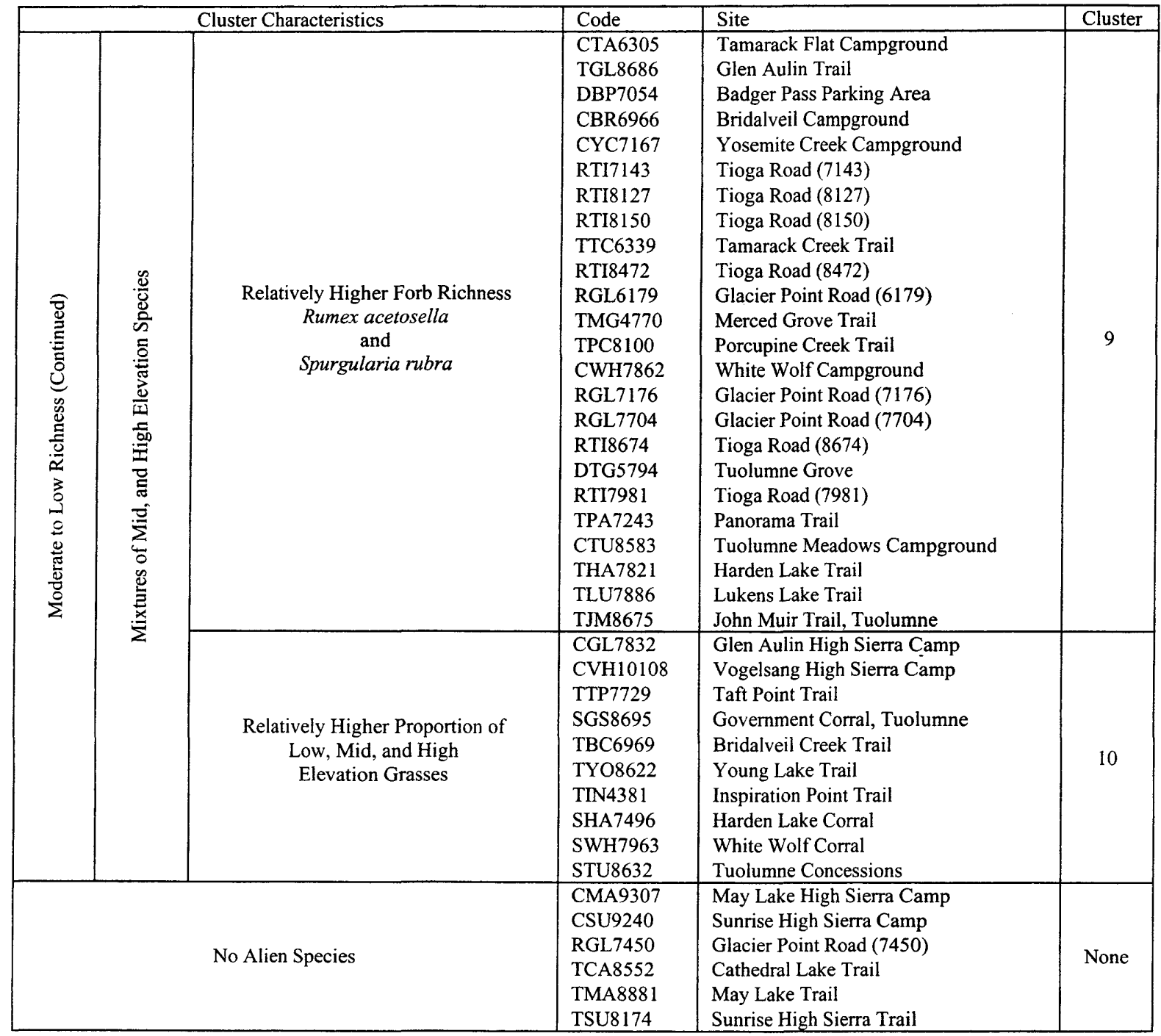

Code: First letter: $\mathrm{C}=$ Campground $\mathrm{D}=$ Development, $\mathrm{R}=$ Paved Road, $\mathrm{S}=$ Stock holding areas, $\mathrm{T}=$ Trail. Second and third letters - Unique site ID. Numerals: \#\#\#=Elevation (ft).

Cluster 9 consists of mid- to high-elevation sites $(1,830-2,745 \mathrm{~m} ; 6,000-9,000 \mathrm{ft})$ that possess Rumex acetosella and Spergularia rubra and have relatively high alien species richness. Merced Grove Trail $(1,455 \mathrm{~m} ; 4,770 \mathrm{ft})$ is an anomaly in this cluster, but the survey notes describe it as a combination dirt road and trail, and that may reflect differences in site history. Cluster 10 consists of high-elevation sites $(2,285-3,050 \mathrm{~m} ; 7,500-10,000 \mathrm{ft})$ that possess a relatively high proportion of low-, mid- and high-elevation grasses. Finally, the sites with no alien species are all high-elevation sites $(2,285$ $2,895 \mathrm{~m} ; 7,500-9,500 \mathrm{ft})$.

\section{Part III. Alien Species Threat Assessment and Prioritization}

\section{Introduction}

All alien species discovered during the directed surveys were grouped into one of four management priority categories based on their attributes, potential impacts and geographical extent (tables 6 and 7). Category 1 alien species are currently restricted to a relatively small number of sites in each park and have either been shown to greatly affect native vegetation or have a high probability of causing serious 
impacts. Category 2 species are restricted to a relatively small number of sites and are ones that generally have a lesser effect on native vegetation. Category 3 species are broadly distributed in the parks, are apparently increasing their ranges within the parks, and are those that have been shown to have a great impact on native vegetation. Category 4 species are those that were detected by the surveys but not assigned to one of the three ranked categories and are considered low priority.

Complete listings of all priority alien species and their survey locations are given in Appendices A and $\mathrm{B}$, and a complete listing of all alien species in each park with important biological information is provided in the ESTA Species Microsoft ${ }^{\circledR}$ Access database file. The field notes of the Sequoia-Kings Canyon National Parks directed-survey team are provided in Appendix $\mathrm{C}$ for all priority alien species. The assignments of alien species to management categories were based on field assessments, the distribution of each species inside and outside of the parks and information gleaned from the literature. In addition to considering all published sources specific to particular alien species, a large number of ecological, biological invasions, weed, botanical, agronomic, and range science sources were considered in the ranking of the alien species. The most relevant sources are included in the "ESTA Bibliography.enl" EndNote $^{\circledR}$ database file that has also been converted to a ProCite ${ }^{\circledR}$ database file (USGS Research Office, Sequoia or Yosemite National Parks); either can be searched using the keyword field. Additionally, the "CalFlora Distribution Maps" directory contains all available statewide distributions by county saved as image files from the CalFlora web site (CalFlora 2000). CalFlora is a comprehensive, web based, publicly accessible database of plant distribution information for California based on over 600,000 specific plant observations from disparate sources. All available CalFlora distribution maps for priority alien species are included in Appendix $G$ showing statewide distributions by county. Summaries were compiled from various sources regarding effective control measures for many of the exotic species found on surveys (The Nature Conservancy 2000, Peirce 1998). The synthesis of this information provided a frame of reference to rank species for which there is little published data and to anticipate synergistic responses between species such as occurs in mixed swards of legumes and grasses.

The ranking of the alien species into the four management categories provides general guidance for management prioritization in the parks. Category 1 species require immediate management action to isolate and eliminate their populations. In some cases the geographical distribution of a Category 1 species will dictate how management efforts are implemented. For example, in Yosemite National Park, a few Category 1 species are found in Yosemite Valley and also at Wawona and Foresta. The highest control priority selected by park managers might be to eliminate those species from Yosemite Valley and to implement a management plan to prevent their spread in Wawona and Foresta. Category 2 species are predicted to have a lesser impact in the parks, but those predictions are based on very little data. At some park locations, Category 2 species can be eliminated along with Category 1 species without expending significant additional park resources. Category 3 dicot species cannot be eliminated without expending a significant amount of park resources while Category 3 grass species will be impossible to eliminate, and management efforts should focus on sites of great importance and on reducing seed dispersal. There is insufficient evidence to indicate that Category 4 species should receive priority for management at this time.

Each alien species has been assigned to a particular tactical class (e.g. localized legumes) in addition to being ranked into the three management categories (tables 6 and 7). The tactical classes organize alien species with broadly similar ecological characteristics into classes that will require similar management techniques or approaches. There are other possible groupings of the alien species in addition to the management categories and tactical classes. Four of the most important additional groupings consist of species that have been introduced to California to provide forage for animals, species that have been introduced 
Table 6. Priority alien species other than grasses

\begin{tabular}{|c|c|c|c|c|c|c|}
\hline Class & Species & Category & $\mathbf{S}$ & $\mathbf{Y}$ & Dispersal Mechanisms & $\begin{array}{c}\text { Seed } \\
\text { Longevity }\end{array}$ \\
\hline \multirow{2}{*}{$\begin{array}{l}\text { Broad } \\
\text { Dist. }\end{array}$} & \multirow{2}{*}{$\begin{array}{l}\text { Cirsium vulgare } \\
\text { Verbascum thapsus }\end{array}$} & 3 & $\sqrt{ }$ & $\sqrt{ }$ & Adhesive, ant, hay, machinery, soil, stock yard, water & 5 yrs \\
\hline & & 3 & $\sqrt{ }$ & $\sqrt{ }$ & Dung, water & $>35$ yrs \\
\hline \multirow{19}{*}{ 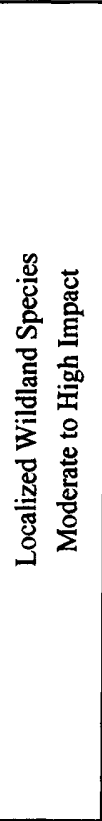 } & \multirow{19}{*}{$\begin{array}{l}\text { Carduus pycnocephalus } \\
\text { Centaurea maculosa } \\
\text { Centaurea solstitialis } \\
\text { Convolvulus arvensis } \\
\text { Erigeron strigosus } \\
\text { Foeniculum vulgare } \\
\text { Geranium robertianum } \\
\text { Hypericum perforatum } \\
\text { Marrubium vulgare } \\
\text { Mentha pulegium } \\
\text { Mentha spicata } \\
\text { Oxalis pes-caprae } \\
\text { Ranunculus parviflorus } \\
\text { Ranunculus testiculatus } \\
\text { Silybum marianum } \\
\text { Tamarix sp. } \\
\text { Tragopogon dubius } \\
\text { Urtica urens } \\
\text { Verbascum virgatum }\end{array}$} & 1 & $\sqrt{ }$ & $\sqrt{ }$ & Adhesive, ant, hay, soil, vehicles, wind & $>10$ yrs \\
\hline & & 1 & & $\sqrt{ }$ & Adhesive, dung, hay, mud, machinery, vehicles, water & $>8$ yrs \\
\hline & & 1 & $\sqrt{ }$ & $\sqrt{ }$ & Adhesive, hay, machinery, soil, stock yard & $>10 \mathrm{yrs}$ \\
\hline & & 1 & $\sqrt{ }$ & $\sqrt{ }$ & Bird droppings, dung, hay, machinery, soil & $>20$ yrs \\
\hline & & 1 & & $\sqrt{ }$ & Adhesive, wind & \\
\hline & & 1 & & $\sqrt{ }$ & Adhesive, ant & \\
\hline & & 1 & & $\sqrt{ }$ & Adhesive & \\
\hline & & 1 & & $\sqrt{ }$ & Adhesive, dung, machinery, vehicles, water & $10 \mathrm{yrs}$ \\
\hline & & 1 & $\sqrt{ }$ & $\sqrt{ }$ & Adhesive, dung, stockyard & $10 \mathrm{yrs}$ \\
\hline & & 1 & $\sqrt{ }$ & & Adhesive, dung, machinery, mud, vehicles & \\
\hline & & 1 & $y$ & $\sqrt{ }$ & & \\
\hline & & 1 & $\sqrt{ }$ & & Ants, soil & \\
\hline & & 1 & $\sqrt{ }$ & & & \\
\hline & & 1 & $\sqrt{ }$ & & Adhesive & \\
\hline & & 1 & $\sqrt{ }$ & & Ant, dung, machinery, soil, stock yard, water, wind & \\
\hline & & 1 & $\sqrt{ }$ & & Water, wind & \\
\hline & & 1 & $\sqrt{ }$ & $\sqrt{ }$ & Water, wind & $2 \mathrm{yrs}$ \\
\hline & & 1 & $\sqrt{ }$ & $\sqrt{ }$ & Dung, stock yard & 5 yrs \\
\hline & & 1 & $\sqrt{ }$ & & & \\
\hline & Lathyrus latifolius & 1 & $\sqrt{ }$ & $\sqrt{ }$ & & \\
\hline & Medicago sativa & 1 & $\sqrt{ }$ & & Feed pellets, hay, dung, stock yard, water & $20 \mathrm{yrs}$ \\
\hline 总 & Melilotus alba & 1 & $\sqrt{ }$ & $\sqrt{ }$ & Adhesive, dung, water & $>20 \mathrm{yrs}$ \\
\hline 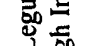 & Melilotus indica & 1 & $\sqrt{ }$ & $\sqrt{ }$ & Stock yard & 5 yrs \\
\hline 焉 & Melilotus officinalis & 1 & $\sqrt{ }$ & $\sqrt{ }$ & Adhesive & $>20 \mathrm{yrs}$ \\
\hline 胥 & Trifolium repens & 1 & $\sqrt{ }$ & $\sqrt{ }$ & Adhesive, dung, mud, vehicles & $30 \mathrm{yrs}$ \\
\hline$\stackrel{8}{8}$ & Vicia benghalensis & 1 & $\sqrt{ }$ & $\sqrt{ }$ & & \\
\hline & Vicia sativa & 1 & $\sqrt{ }$ & & & \\
\hline & Vica villosa & 1 & $\sqrt{ }$ & & Bird droppings, dung, mud & \\
\hline & Carya sp. & 2 & $\sqrt{ }$ & & Animals, water & \\
\hline & Diospyros sp. & 2 & $\sqrt{ }$ & & Animals, water & \\
\hline & Ficus carica & 1 & $\sqrt{ }$ & & Bird droppings, water & \\
\hline हू & Juglans californica & 1 & $\sqrt{ }$ & & Animals, water & \\
\hline$\stackrel{5}{3}$ & Juglans regia & 1 & j & & Animals, water & \\
\hline Zूँّ & Malus sylvestris & 1 & $\sqrt{ }$ & $?$ & Animals, water & \\
\hline 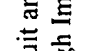 & Morus alba & 1 & $\sqrt{ }$ & & Bird droppings, water & \\
\hline 로 & Olea europaea & 2 & $\sqrt{ }$ & & Bird droppings, water & \\
\hline & Prunus persica & 2 & $\sqrt{ }$ & & Animals & \\
\hline$\overline{\mathrm{J}}$ & Punica granatum & 2 & $\sqrt{ }$ & & Animals & \\
\hline & Rubus discolor & 1 & $\sqrt{ }$ & $\sqrt{ }$ & Bird droppings, water & \\
\hline & Rubus lacinatus & 1 & & $\sqrt{ }$ & Bird droppings, water & \\
\hline & Vitis vinifera & 1 & $\sqrt{ }$ & $\sqrt{ }$ & Bird droppings, water & \\
\hline
\end{tabular}


Table 6. Priority alien species other than grasses--Continued

\begin{tabular}{|c|c|c|c|c|c|c|}
\hline Class & Species & Category & $\mathbf{S}$ & $\mathbf{Y}$ & Dispersal Mechanisms & $\begin{array}{l}\text { Seed } \\
\text { Longevity }\end{array}$ \\
\hline \multirow{19}{*}{ 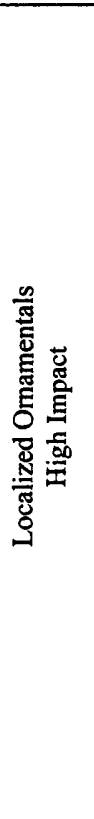 } & \multirow{19}{*}{$\begin{array}{l}\text { Ampelopsis arborea } \\
\text { Catalpa bignonioides } \\
\text { Cistus sp. } \\
\text { Coreopsis lanceolata } \\
\text { Digitalis purpurea } \\
\text { Eucalyptus citriodora } \\
\text { Genista monspessulana } \\
\text { Hedera helix } \\
\text { Heteromeles arbutifolia } \\
\text { Iris sp. } \\
\text { Leucanthemum vulgare } \\
\text { Leucojum aestivum } \\
\text { Ligustrum sinense } \\
\text { Nerium oleander } \\
\text { Pyracantha angustifolia } \\
\text { Rudbeckia hirta } \\
\text { Spartium junceum } \\
\text { Tanacetum parthenium } \\
\text { Vinca major }\end{array}$} & 1 & $\sqrt{ }$ & & Bird droppings, water & \\
\hline & & 1 & $\sqrt{ }$ & & Wind, water & \\
\hline & & 1 & $\sqrt{ }$ & & & \\
\hline & & 1 & & $\sqrt{ }$ & Adhesive, wind & \\
\hline & & 1 & $\sqrt{ }$ & $\sqrt{ }$ & Mud, vehicles, wind & $>5 \mathrm{yrs}$ \\
\hline & & 1 & $\sqrt{ }$ & & Wind & \\
\hline & & 1 & $\sqrt{ }$ & & Ant, bird droppings, explosive, mud, machinery, water & $>5 \mathrm{yrs}$ \\
\hline & & 1 & $\sqrt{ }$ & $\mathrm{V}$ & Bird droppings & \\
\hline & & 1 & $\sqrt{ }$ & & Bird droppings & \\
\hline & & 2 & $\sqrt{ }$ & & & \\
\hline & & 1 & & $\sqrt{ }$ & Adhesive, dung, hay, wildflower seed mix & $39 \mathrm{yrs}$ \\
\hline & & 2 & $\sqrt{ }$ & & & \\
\hline & & 1 & $\sqrt{ }$ & & Bird droppings, water & \\
\hline & & 1 & $\sqrt{ }$ & & Water, wind & \\
\hline & & 1 & $\sqrt{ }$ & & Bird droppings, water & \\
\hline & & 1 & & $\sqrt{ }$ & & \\
\hline & & 1 & $\sqrt{ }$ & & Ants, water & $>5 \mathrm{yrs}$ \\
\hline & & 1 & $\sqrt{ }$ & $\sqrt{ }$ & Mud, vehicles & \\
\hline & & 1 & $\sqrt{ }$ & $\sqrt{ }$ & & \\
\hline
\end{tabular}

Notes: Class = tactical class; \# = Priority Category; $\mathrm{S}=$ Sequoia-Kings Canyon National Parks, $\mathrm{Y}=$ Yosemite National Park (? indicates present in flora but not found in directed surveys); seed longevity = viability under natural soil conditions.

and bred for use as turf-grasses, species that have evolved to invade grazing and forageproduction systems and species intentionally introduced for horticultural reasons. Forage species and grazing and forage-production invasive species constitute 55 percent of the 89 priority alien species and other intentional introductions constitute another 39 percent for a total of 94 percent of all priority species. Certainly, many of the species in these three groupings are present in the parks because they have spread into the parks from their initial sites of introduction. Nevertheless, they illustrate the management importance of those groupings of species because controlled and uncontrolled access to the parks by domesticated grazing animals still occurs, and the introduction of additional horticultural species is still being considered.

Forage species represent a particularly important category of alien species. Because of their economic importance for livestock production, they are continually being imported from Eurasia, hybridized, and selected for particular important traits by geneticists and plant breeders 28 working for the United States Department of Agriculture, Agricultural Research Service, Rangeland, Pasture and Forages Program as well as scientists at many academic institutions. Unlike most horticultural species, many forage species are selected for their ability to establish and persist in natural plant communities, as well as in human-modified environments. Many legumes and perennial grasses that have been introduced to increase forage production have become problem alien species (Anonymous 1972, Carrier and Bort 1916, Elliot 1949, Apfelbaum and Sams 1987, Tyser and Worley 1992, Grilz and Romo 1995, Blankespoor and May 1996, Harrison et al. 1996, Batcher 1999). Additionally, new varieties of alien species that are known to invade natural areas are continually being imported (Dewey and Plummer 1980), and existing varieties are being bred for increased resistance to pathogens and pests, as well as increased cold tolerance (Kehr et al. 1984, Asay et al. 1991, Rumbaugh et al. 1991). The continuous importation, breeding, varietal selection, seed certification and seed distribution programs that are related to the economic production of forage crop species may 
Table 7. Priority alien grass species

\begin{tabular}{|c|c|c|c|c|c|c|}
\hline Class & Species & Category & $\mathbf{S}$ & $\mathbf{Y}$ & Dispersal Mechanisms & $\begin{array}{c}\text { Seed } \\
\text { Longevity } \\
\end{array}$ \\
\hline \multirow{2}{*}{$\begin{array}{l}\text { Broad } \\
\text { Dist. }\end{array}$} & \multirow{2}{*}{$\begin{array}{l}\text { Bromus tectorum } \\
\text { Poa pratensis }\end{array}$} & 3 & $\sqrt{ }$ & $\sqrt{ }$ & Adhesive, footwear, dung, hay, vehicles & 5 yrs \\
\hline & & 3 & $\sqrt{ }$ & $\sqrt{ }$ & Adhesive, dung & $4 \mathrm{yrs}$ \\
\hline \multirow{23}{*}{ 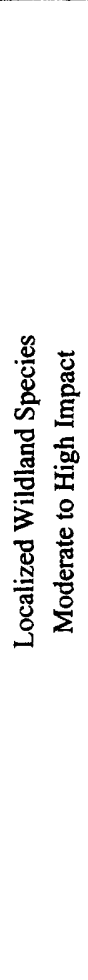 } & \multirow{23}{*}{$\begin{array}{l}\text { Agrostis capillaris } \\
\text { Agrostis gigantea } \\
\text { Arundo donax } \\
\text { Bromus inermis } \\
\text { Dactylis glomerata } \\
\text { Echinochloa crus-galli } \\
\text { Festuca arundinacea } \\
\text { Festuca pratensis } \\
\text { Holcus lanatus } \\
\text { Lolium perenne } \\
\text { Phalaris arundinacea } \\
\text { Phalaris minor } \\
\text { Phalaris paradoxa } \\
\text { Phleum pratense } \\
\text { Piptatherum miliaceum } \\
\text { Poa bulbosa } \\
\text { Poa compressa } \\
\text { Poa palustris } \\
\text { Polypogon australis } \\
\text { Polypogon interruptus } \\
\text { Polypogon monspeliensis } \\
\text { Sorghum halepense } \\
\text { Vulpia bromoides }\end{array}$} & 1 & $?$ & $\sqrt{ }$ & & \\
\hline & & 1 & $?$ & $?$ & Dung, water & \\
\hline & & 1 & $\sqrt{ }$ & & Water & \\
\hline & & 1 & & $\sqrt{ }$ & & \\
\hline & & 1 & $\sqrt{ }$ & $\sqrt{ }$ & Adhesive, dung, water & 5 yrs \\
\hline & & 2 & $\sqrt{ }$ & & Dung, rice straw, stock yard, water & 12 yrs \\
\hline & & 1 & $\sqrt{ }$ & & & 2 yrs \\
\hline & & 2 & $\sqrt{ }$ & & & \\
\hline & & 2 & $\sqrt{ }$ & $\sqrt{ }$ & Adhesive, bird droppings, dung, mud, soil, stock yard & $>10$ yrs \\
\hline & & 2 & $\sqrt{ }$ & $\sqrt{ }$ & Adhesive, dung, mud, stock yard, vehicles & 4 yrs \\
\hline & & 1 & $\sqrt{ }$ & & Bird droppings, dung & \\
\hline & & 2 & $\sqrt{ }$ & & & \\
\hline & & 2 & $\sqrt{ }$ & & Stock yard & \\
\hline & & 2 & $\sqrt{4}$ & $\sqrt{ }$ & & \\
\hline & & 2 & $\sqrt{ }$ & & Bird droppings & \\
\hline & & 2 & $\sqrt{ }$ & $\sqrt{ }$ & & \\
\hline & & 2 & $\sqrt{ }$ & $\sqrt{ }$ & Dung & \\
\hline & & 1 & $?$ & $?$ & & \\
\hline & & 1 & $\sqrt{ }$ & & & \\
\hline & & 1 & $\sqrt{ }$ & & & \\
\hline & & 2 & $\sqrt{ }$ & $\sqrt{ }$ & Dung, stock yard & \\
\hline & & 2 & $\sqrt{ }$ & & Bird droppings, dung, hay, machinery, stockyard & $>5 \mathrm{yrs}$ \\
\hline & & 2 & $\sqrt{ }$ & & Adhesive, dung & \\
\hline
\end{tabular}

Notes: Class = tactical class; \# = Priority Category; $\mathrm{S}=$ Sequoia-Kings Canyon National Parks, $\mathrm{Y}=$ Yosemite National Park (? indicates present in flora but not found in directed surveys); seed longevity = viability under natural soil conditions.

lead to dramatic changes in the invasiveness and dispersal distances of a forage species in the year certified seed is released to the public. For example, interactions between selected traits such as disease resistance and environmental factors such as minimum winter temperatures may potentially allow some forage species to expand their range into colder climates (Myers and Chilton 1941).

Synergistic effects between forage species, such as legume and grass mixtures, may also lead to greater persistence of forage species in natural plant communities (Evans 1916, Looman 1976, Casler and Carlson 1995, Warren 2000). Also, under particular environmental conditions, many grass forage species may be toxic to herbivores due to endophytic Clavibacter/Anguina associations (McClay and Ophel 1993, Edgar 1994). Most scientific research on this issue has focused on domestic animal deaths but the toxin is known to greatly increase the frequency of abortions in sheep (McClay and Ophel 1993), and there is no information concerning its effects on wild herbivores. Finally, the climatic and geographical locations of the various forage species breeding programs in the western United States ensures that the parks are within the dispersal distance of forage species that are adapted to many different habitats and climates. Species adapted to northern-European-type climates are being bred in Oregon's Willamette Valley and near Pullman, Washington; species adapted to central Asian steppe and high altitude forest climates are being bred in Logan, Utah; and species adapted to Mediterranean-type climates are being bred in California. The distributions of adapted forage species are not random. Mediterranean type climate adapted forage species are grown west of the Sierra Nevada, steppe and high altitude forest adapted forage species are grown east of the Sierra 
Nevada, and northern European type climate forage species are grown in meadows and lower elevation logged forests throughout the western United States.

Turfgrass species used for golf courses and lawns are often the same species used in forage production systems but bred for different characteristics. Currently, there are a number of notifications filed with USDA-APHIS to release transgenic Agrostis stolonifera (creeping bent) and Poa pratensis cultivars that have been modified for glyphosate and glufosinate resistance. The stated intent of the developers of these transgenic cultivars is to reduce the amount of herbicides necessary to keep golf courses free of undesirable grasses such as Poa annua (annual bluegrass) (Neal 2000, Wipff and Rose-Fricker 2000). However, there is concern among some scientists in the turfgrass industry that the continuous use of glyphosate will select for glyphosate resistant perennial grasses (Neal 2000). Additionally, the primary method for killing the resistant transgenic cultivars is to fumigate with methyl bromide, which will be banned after 2005 (Neal 2000).

Gene flow to closely-related species is also a serious concern as in one field test of transformed $A$. stolonifera where a marker gene was detected in untransformed plants at distances up to $298 \mathrm{~m}(980 \mathrm{ft})$, and gene flow was predicted to have occurred up to a distance of $1,310 \mathrm{~m}(4,300 \mathrm{ft})$ from the transgenic plants (Wipff and Rose-Fricker 2000). Those researchers noted that $A$. canina, $A$. capillaris, $A$. castellana, $A$. gigantea, $A$. stolonifera and $A$. vinealis (velvet bent, colonial bent, highland bent, giant bent grass, creeping bent and brown bent grass, respectively) freely hybridize and recommended that transgenic $A$. stolonifera seed not be produced until a male sterility system is developed (Wipff and Rose-Fricker 2000). The same company that sponsored the $A$. stolonifera transgenic research is now marketing glyphosate-resistant cultivars of Festuca arundinacea (tall fescue) and Festuca trachyphylla (hard fescue) that were developed through long-term herbicide selection experiments (Rose-Fricker 2000). The development of glyphosate-resistant cultivars of these known invaders of riparian habitats means that they will be resistant to Rodeo ${ }^{\circledR}$, one of the very few herbicides registered for use near riparian areas and wetlands. It is therefore absolutely critical that these cultivars not be introduced into the parks.

Additionally, as Poa pratensis and Agrostis gigantea are dispersed in animal dung, all efforts should be made to stop seed dispersal into the parks by domestic animals. There are a number of other species that are now being promoted for use as turfgrass. The USDA-ARS at Logan, Utah, has released cultivars of Agropyron cristatum (crested wheatgrass) for turfgrass use in the Intermountain West; a European cultivar of Koeleria macrantha (junegrass) is being developed for dry and infertile soils and a European cultivar of Festuca rubra (red fescue) is being developed for damp and shady areas (Brede 2000). Cold-tolerant Lolium perenne (perennial ryegrass) is being bred to extend the climatic range of that turfgrass species (Ebdon 2000).

\section{Priority Alien Species Other Than Grasses}

\section{Localized Wildland Species with Moderate to High Impact - Category 1 Species}

Carduus pycnocephalus (Italian thistle) is $0.2 \mathrm{~m}$ to $2.0 \mathrm{~m}$ tall annual thistle that is ranked as a lesser invasive species by the California Alien Pest Plant Council (CalEPPC 1999). Its CalFlora distribution indicates that this species is widespread in California (Appendix G) and that its range in the Sierra Nevada appears to be increasing (Gerlach, personal observation). The distribution of $C$. pycnocephalus in the parks supports this observation. In Sequoia-Kings Canyon National Parks the only large population was discovered at the Ash Mountain Headquarters, and the remaining small populations are isolated and located in campgrounds, parking lots and in a streambed (Appendix A). In Yosemite National Park it is present only at the closed Lower River Campground which supports a large number of alien species (Appendix B). Unlike all other alien thistles that are invading California's wildlands, $C$. pycnocephalus forms dense populations under tree canopies and ultimately 
excludes native species from those habitats. $C$. pycnocephalus seed is dispersed by adhering to animals and humans, by ants, as a contaminant in hay and soil, and by vehicles and wind (Ridley 1930, Evans et al. 1979, Pemberton and Irving 1990, Bossard and Lichti 2000). Its seed remains viable in the soil for more than 10 years (Parsons and Cuthbertson 1992).

Centaurea maculosa (spotted knapweed) is a $0.2 \mathrm{~m}$ to $1.2 \mathrm{~m}$ tall perennial thistle that is ranked as a red alert species by CalEPPC. Its CalFlora distribution indicates that numerous small populations exist in northern California (Appendix G). The directed surveys found it in Yosemite National Park at Foresta. C. maculosa has the potential to invade meadows and open forests to an elevation of $3,000 \mathrm{~m}$. The $C$. maculosa seed is dispersed by adhering to animals and clothing, by ants, in dung, as a contaminant in hay and feed pellets, and by vehicles, mud, and water (Watson and Renney 1974, Pemberton and Irving 1990, Wallender et al. 1995, Sheley et al. 1999). The seed remains viable in the soil for more than 8 years (Davis et al. 1993).

Centaurea solstitialis (yellow star-thistle) is a $0.1 \mathrm{~m}$ to $2.0 \mathrm{~m}$ tall annual thistle that is ranked as one of the most invasive alien species by CalEPPC. It is widespread in California but the largest populations are in central and northern valleys and foothills (DiTomaso and Gerlach Jr. 2000). C. solstitialis is extending its range into the central Sierra Nevada (DiTomaso and Gerlach Jr. 2000) but the upper altitudinal limits of its range are not yet known. Active management programs are in place at all three parks. The directed surveys found this species in Sequoia-Kings Canyon National Parks along the Generals Highway and at Swale Campground and in Yosemite National Park at El Portal, Foresta, Hetch Hetchy Corral, McCauley Ranch and along Wawona Road. C. solstitialis seed is dispersed by adhering to animals and clothing, in contaminated hay and soil and on vehicles and machinery (DiTomaso and Gerlach Jr. 2000). Its seed remains viable in the soil for more than 10 years (Calihan et al. 1993).

Convolvulus arvensis (bindweed) is a twining perennial from deep, persistent roots that was considered but not listed as a serious invasive species by CalEPPC and is ranked as a lesser invasive species by the Pacific Northwest Alien Pest Plant Council (PNEPPC 1997). It is a noxious weed on arable lands and a problem alien species in Yellowstone National Park (Anonymous 1992). Its CalFlora distribution indicates that it is widely distributed in California (Appendix G). The directed surveys found it in Sequoia-Kings Canyon National Parks at Potwisha Campground and in Yosemite National Park at El Portal, McCauley Ranch and Yosemite Village. Its seed is dispersed in bird droppings, dung, hay and by machinery (Harmon and Keim 1934, Weaver and Riley 1982, Parsons and Cuthbertson 1992). Its seed remains viable in the soil for more than 20 years (Weaver and Riley 1982).

Erigeron strigosus (tall fleabane) is a $0.3 \mathrm{~m}$ to $0.8 \mathrm{~m}$ tall annual or biennial that has not been considered for ranking as an invasive species by CalEPPC. This species is native to the eastern United States and produces seeds asexually. Its CalFlora distribution indicates that there are only a few scattered populations in California (Appendix G), and the directed surveys found it in Yosemite National Park only at The Ahwahnee hotel.

Foeniculum vulgare (fennel) is a $1.0 \mathrm{~m}$ to $3.5 \mathrm{~m}$ tall perennial herb from a thick taproot and is ranked as one of the most invasive alien species by CalEPPC. Its CalFlora distribution indicates that it is widespread near the coast and suggests that it is invading the Central Valley and Mono County (Appendix G). The directed surveys found it in Yosemite National Park only at Lower River Campground. F. vulgare seed is dispersed by adhering to animals and clothing, by ants, on vehicles and by water (Ridley 1930 , Klinger 2000). It is an extremely difficult species to eradicate once it has established due to its large taproot and its enormous and longlived seedbank (Klinger 2000). F. vulgare also forms large, dense populations that drastically alter the species composition and structure of grassland, riparian and wetland communities (Klinger 2000).

Geranium robertianum (Robert's geranium) is a $.01 \mathrm{~m}$ to $0.5 \mathrm{~m}$ tall annual or biennial that is ranked as a red alert species by the Pacific 
Northwest Alien Pest Plant Council (PNEPPC). Its CalFlora distribution indicates that it is present in Alameda, Sonoma, and Napa counties (Appendix G), and the directed surveys found it in Yosemite National Park only at Lower River Campground. Its seed is adhesive (Ridley 1930) and is probably dispersed by adhering to animals, clothing and vehicles.

Hypericum perforatum (Klamathweed, St. John's wort) is a $0.3 \mathrm{~m}$ to $1.2 \mathrm{~m}$ tall perennial from a deep taproot and lateral rhizomes and is ranked as a lesser invasive species by CalEPPC. Its CalFlora distribution is primarily along the coast, in northwest California and in the northern Sierra Nevada (Appendix G). The directed surveys found this species only at a restricted number of locations in Yosemite National Park (Appendix B). Biological control efforts have greatly reduced the size of many California populations but in Idaho, Oregon and Washington populations are still increasing in size despite the presence of biological control agents (Piper 1999). Biological control agents have not been effective in controlling $H$. perforatum in Australia (Parsons and Cuthbertson 1992). Despite the success of the biological control program in California, sustaining current levels of control requires a good habitat match for the biological control agents, that the agents remain unaffected by parasites or pathogens and that $H$. perforatum not adapt to the agents by becoming more resistant through natural selection. For these reasons it seems prudent that the control of $H$. perforatum should not depend exclusively on biological control agents. $H$. perforatum seed is dispersed by adhering to animals, clothing, in dung, by machinery, vehicles and water. It also spreads vegetatively through the growth of rhizomes. Its seed remains viable in the soil for at least 10 years (Bellue 1945). H. perforatum is toxic to most herbivores (Fuller and McClintock 1986, Piper 1999).

Marrubium vulgare (horehound) is a $0.1 \mathrm{~m}$ to $1.0 \mathrm{~m}$ tall bushy perennial that was considered but not listed by the PNEPPC. It is one of the most widespread alien plant species in the Mediterranean-type climate areas of southern Australia (Parsons and Cuthbertson 1992). Its CalFlora distribution indicates that it is widespread in California and suggests that it is now invading the foothills of the Sierra Nevada (Appendix G). The small number of populations discovered by the directed surveys, Buckeye Campground and Potwisha Campground in Sequoia-Kings Canyon National Parks and El Portal, Happy Isles, and Lower River Campground in Yosemite National Park, also suggests that this species is just beginning to invade the Sierra Nevada. In Sequoia-Kings Canyon National Parks, park maintenance workers report a marked increase in population size in recent years (Appendix C). M. vulgare seed is dispersed by adhering to animals, clothing and by horse dung (Ridley 1930, St John-Sweeting and Morris 1990). Its seed remains viable in the soil for at least 10 years (Weiss and Sagliocco 2000).

Mentha pulegium (pennyroyal) is a $0.1 \mathrm{~m}$ to 0.9 $\mathrm{m}$ tall bushy, stoloniferous perennial that is ranked as one of the most invasive alien species by CalEPPC. Its CalFlora distribution indicates that is common in coastal areas and suggests that it is invading the Sierra Nevada along river drainages (Appendix G). It was found only in Sequoia-Kings Canyon National Parks in the riverbed of the North Fork of the Kaweah River. The notes of the survey team state that dozens of plants were found in partly shaded, rocky and sandy places in and adjacent to the floodplain of the Kaweah River (Appendix A). All parts of the plant are toxic, and it has been used as an insect repellant (Fuller and McClintock 1986, Hickman 1993). Its seed is dispersed by adhering to animals, clothing, in cow dung, in contaminated hay, mud, soil, by vehicles, machinery and water (Parsons and Cuthbertson 1992, Warner 2000). It is also spread by the fragmentation of stolons that are subsequently transported by vehicles and water (Warner 2000).

Mentha spicata (spearmint) is a $0.3 \mathrm{~m}$ to $1.2 \mathrm{~m}$ tall bushy, stoloniferous perennial that has not been considered for ranking as an invasive species by CalEPPC. Its CalFlora distribution indicates that it is common in California (Appendix G) but the directed-search data suggest that it may be invading the same habitats as Mentha pulegium. The directed surveys found it in Sequoia-Kings Canyon National Parks in 
the riverbed of the North Fork of the Kaweah River and in Yosemite National Park at The Ahwahnee hotel and at El Portal.

Oxalis pes-caprae (Bermuda buttercup) is a 0.2 $\mathrm{m}$ to $0.4 \mathrm{~m}$ tall rhizomatous perennial that requires more study according to CalEPPC. It is considered a noxious weed in many parts of the world. Its CalFlora distribution indicates that it is mostly confined to coastal areas and suggests that it is now invading the Sierra Nevada (Appendix G). It was found only in SequoiaKings Canyon National Parks in the Ash Mountain Developed Area and along the Generals Highway. O. pes-caprae forms dense populations that spread from rhizomes and bulbs that are dispersed in contaminated soil and on machinery (Parsons and Cuthbertson 1992, Peirce 1997). Most populations do not produce viable seed. The failure to produce viable seed due to self-incompatibility has been overcome by extensive selfing in other self-incompatible species (Hiscock 2000). This characteristic should not be relied upon to limit the spread of alien species. $O$. pes-caprae is toxic to livestock (Fuller and McClintock 1986, Parsons and Cuthbertson 1992) and presumably to native herbivores also.

Ranunculus parviflorus (small flowered buttercup) is a $0.1 \mathrm{~m}$ to $0.8 \mathrm{~m}$ tall annual that has not been considered for ranking as an invasive species by CalEPPC. Its CalFlora distribution indicates that it is common in wet areas along the coast and suggests that it is now invading the Sierra Nevada (Appendix G). It is toxic although most herbivores will not eat it due to its bitter taste (Fuller and McClintock 1986).

Ranunculus testiculata (bur buttercup) is a 0.01 to 0.1 tall annual that has not been considered for ranking as an invasive species by CalEPPC. It is a widespread invasive species that has invaded Bromus tectorum-dominated grasslands throughout the Intermountain West, eastern Oregon, eastern Washington and Idaho (Young et al. 1992). Its CalFlora distribution indicates that it is present in Kern, Modoc, Mono and Lassen counties and strongly suggests that stock animals (Appendix G) are dispersing it. It was only found in Sequoia-Kings Canyon National Parks at Sentinel Campground. Its seed is dispersed by adhering to animals (Young et al. 1992), and all parts of the plant are toxic although most herbivores will not eat it due to its bitter taste (Fuller and McClintock 1986, Young et al. 1992). Because it has proven its ability to invade stands of Bromus tectorum, it is likely that $R$. testiculata is capable of invading many habitats in all three parks where Bromus tectorum currently exists.

Silybum marianum (milk thistle) is a $0.3 \mathrm{~m}$ to $2.5 \mathrm{~m}$ tall, annual or biennial thistle that requires more study according to CalEPPC. Its CalFlora distribution indicates that this species is widespread in coastal areas and suggests that it is invading the Sierra Nevada (Appendix G). The directed surveys found it in Sequoia-Kings Canyon National Parks along Old Hidden Springs Road and in nearby Yucca Creek. This species invades areas with bare soil and produces dense populations that crowd out all other species and ensures that there is bare soil for germination in subsequent years (Parsons and Cuthbertson 1992). Its seed is spread by ants, in hay, by machinery, water and wind (Pemberton and Irving 1990, Parsons and Cuthbertson 1992). The Sequoia-Kings Canyon National Parks survey notes indicate that seed of this species is also dispersed in cow dung. Its seed remains viable in the soil for at least 9 years (Parsons and Cuthbertson 1992).

Tamarix species (tamarisk, salt cedar) are $2.0 \mathrm{~m}$ to $6.0 \mathrm{~m}$ tall many-branched shrubs or trees that are ranked as some of the most invasive alien species by CalEPPC. The CalFlora distribution of Tamarix species indicates that they are expanding their ranges into riparian areas of the Central Valley (Appendix G). The directed surveys found these species only in SequoiaKings Canyon National Parks in the beds of the Kaweah River and Sycamore Creek. These species are dispersed by water and wind (Lovich 2000).

Tragopogon dubius (yellow salsify, goat's beard) is a $0.3 \mathrm{~m}$ to $1.0 \mathrm{~m}$ tall annual or biennial that is ranked as one of the most invasive alien species by PNEPPC. Its CalFlora distribution indicates that it is widespread in northeastern California and is present in a couple of counties along the coast and also in Mono County (Appendix G). It is found in all three parks. In 
Sequoia-Kings Canyon National Parks, it is found in Halstead Meadow, Wolverton Pack Station, in developed areas and campgrounds and along the Generals Highway (Appendix A). In Yosemite National Park, it is found at McCauley Ranch and the Concession Stables (Yosemite Valley), in developed areas and campgrounds and along trails and roads (Appendix B). Its seed is dispersed by water and wind (Ridley 1930, Kelley and Bruns 1975) and probably by adhering to animals. Its seed is viable in the soil for at least 2 years (Clements et al. 1999).

Urtica urens (dwarf nettle, burning nettle) is a $0.1 \mathrm{~m}$ to $0.6 \mathrm{~m}$ tall annual stinging nettle that has not been considered for ranking by CalEPPC. Its CalFlora distribution indicates that it is widespread along the coast and in southern California and suggests that it is spreading in central California (Appendix G). The directed surveys found it in Sequoia-Kings Canyon National Parks at the Ash Mountain Slash Pit, Cedar Grove Pack Station, Grant Grove Pack Station, Mineral King Pack Station and at Potwisha Campground. In Yosemite National Park, it was found at the Government Stables (Yosemite Valley). Its seed is dispersed in the dung of many animals (Ridley 1930, Gray and Michael 1986, Malo and Suarez 1995) and is viable in the soil for over 5 years (Roberts and Feast 1972).

Verbascum virgatum (wand mullein) is a $0.6 \mathrm{~m}$ to $1.2 \mathrm{~m}$ tall biennial that has not been considered for ranking by CalEPPC. Its CalFlora distribution indicates that it has a widespread but very patchy distribution in California (Appendix G). It is present in Sequoia-Kings Canyon National Parks only at Azalea Campground, Lodgepole Developed Area, Red Fir Maintenance Yard, and Wuksachi. There is very little published information on this species but if it is similar to $V$. thapsus (woolly mullein) it will establish a large and long-lived seedbank.

\section{Localized Legumes with Moderate to High Impact - Category 1 Species}

Lathyrus latifolius (perennial sweet pea) is a robust sprawling or climbing perennial that has not been considered for ranking by CalEPPC. Its
CalFlora distribution indicates that it is primarily distributed along the coast and suggests that it may be spreading in the Sierra Nevada (Appendix G). The directed surveys found it in Sequoia-Kings Canyon National Parks at the Ash Mountain Developed Area and in Traugers Creek and in Yosemite National Park at El Portal, Wawona and Yosemite Village. The field notes describing the Traugers Creek area suggest that $L$. latifolius is a serious threat to riparian areas as the survey crew stated: "[ $[$ ]housands of individuals in large, dense colonies were observed at the junction of the Mineral King Road and Traugers Creek. A large colony is directly along the Mineral King Road and extends approximately fifty meters upstream from the road." From these statements it appears likely that the invasion began upstream of the road and has spread downstream. There is no published information about the ecology of this species in wildlands.

Medicago sativa (alfalfa, lucerne) is a $0.2 \mathrm{~m}$ to $0.8 \mathrm{~m}$ tall tap-rooted or rhizomatous perennial that has not been considered for ranking by CalEPPC. It has been identified as a priority species in the Yellowstone National Park area (Anonymous 1992). Its CalFlora distribution indicates that it is common along the coast and east of the Sierra Nevada and is sporadic in the Central Valley (Appendix G). It is certainly a common roadside plant along freeways and highways in the Central Valley (Gerlach, personal observation). The Central Valley populations are likely to be composed primarily of warm climate genotypes while the populations east of the Sierra Nevada are certainly composed of more cold tolerant and possibly stoloniferous genotypes that are a problem in the Yellowstone National Park area (Lowe et al. 1972). The directed surveys found this species only in Sequoia-Kings Canyon National Parks along the flume in the Ash Mountain Developed Area and along the road at Milk Ranch. M. sativa seed is dispersed in feed pellets, hay and horse dung and moves by water (Ridley 1930, Kelley and Bruns 1975, Zamora and Olivarez 1994). Its seed remains viable in the soil for more than 20 years (Lewis 1973). 
Melilotus alba (white sweet clover) is a $0.5 \mathrm{~m}$ to $2 \mathrm{~m}$ tall annual or biennial that is considered to be a lesser invasive by the PNEPPC. Its CalFlora distribution indicates that it is common along the coast and east of the Sierra Nevada, sporadic in the Central Valley and perhaps invading the Sierra Nevada (Appendix G). The directed surveys found this species in SequoiaKings Canyon National Parks at the Cedar Grove Market and Lodge, Dorst Campground and Wuksachi. In Yosemite National Park, it was found at El Portal, Hetch Hetchy Backpacker's Camp and Lower River Campground. $M$. alba seed is dispersed by adhering to animals, clothing, in dung and by water (Harmon and Keim 1934, Kelley and Bruns 1975, Turkington et al. 1978). Its seed remains viable in the soil for more than 30 years (Turkington et al. 1978).

Melilotus indica (sourclover) is a $0.1 \mathrm{~m}$ to $0.6 \mathrm{~m}$ tall annual that has not been considered for ranking as an invasive species by CalEPPC. Its CalFlora distribution indicates that it is common in southern California, sporadic in the Central Valley, and perhaps invading the Sierra Nevada (Appendix G). The directed surveys found this species in Sequoia-Kings Canyon National Parks at the Ash Mountain Developed Area and along the Generals Highway and Sycamore Creek. It was found in Yosemite National Park at El Portal and Hetch Hetchy Backpacker's Camp. Its seed is viable in the soil for more than 5 years (Roberts and Feast 1972).

Melilotus officinalis (yellow sweetclover) is a $0.5 \mathrm{~m}$ to $2.0 \mathrm{~m}$ tall biennial that is considered to be a lesser invasive by the PNEPPC. It has been identified as a priority species in the Yellowstone area (Anonymous 1992). Its CalFlora distribution indicates that it is common along the coast and east of the Sierra Nevada, sporadic in the Central Valley, and perhaps invading the Sierra Nevada (Appendix G). The directed surveys found this species in SequoiaKings Canyon National Parks at Dorst Campground and in Yosemite National Park at El Portal. M. officinalis seed is dispersed by adhering to animals and clothing (Turkington et al. 1978) and is viable in the soil for more than 20 years (Turkington et al. 1978).
Trifolium repens (white clover) is a creeping perennial that roots from stolons and has not been considered for ranking as an invasive species by CalEPPC. Its CalFlora distribution indicates that it is present in most of California (Appendix G). The directed surveys found this species at several locations in both park areas, but the number of individuals in each population was relatively small. Its seed is dispersed by adhering to animals, clothing, in bird droppings, dung, in mud and by vehicles (Ridley 1930, Dore and Ranmond 1942, Gillham 1970, Welch 1985, Mt. Pleasant and Schlather 1994, Malo and Suarez 1995, Fischer et al. 1996, Hodkinson and Thompson 1997). Its seed is viable in the soil for more than 20 years (Toole and Brown 1946).

Vicia benghalensis (purple vetch) is a sprawling or climbing annual that has not been considered for ranking as an invasive species by CalEPPC. Its CalFlora distribution indicates that it is common along the coast and in some parts of the Sacramento Valley (Appendix G). The directed surveys discovered it in Yosemite National Park at El Portal and in Sequoia-Kings Canyon National Parks along Old Hidden Springs Road where a large population is spreading into the adjacent grassland.

Vicia sativa (common vetch) is a sprawling or climbing annual that has not been considered for ranking as an invasive species by CalEPPC. Its CalFlora distribution indicates that it is common along the coast and in some parts of the Sacramento Valley and suggests that it is spreading in the Sierra Nevada (Appendix G). The directed surveys discovered it in SequoiaKings Canyon National Parks at the Ash Mountain Developed Area and along the Generals Highway.

Vicia villosa (hairy vetch, winter vetch) is a sprawling or climbing annual that has not been considered for ranking as an invasive species by CalEPPC. Its CalFlora distribution indicates that it is widely distributed in California (Appendix $\mathrm{G})$. The directed surveys discovered it in Sequoia-Kings Canyon National Parks along the Generals Highway. Its seed is dispersed in bird droppings, dung and mud (Aarssen et al. 1986). 
Localized Fruit and Nut Species With High Impact - Category 1 and 2 Species

Carya sp. (pecan) is a $20 \mathrm{~m}$ tall deciduous nut tree that has not been considered for ranking as an invasive species by CalEPPC. Animals and water probably disperse its seed. The directed surveys found one mature tree in Sequoia-Kings Canyon National Parks at Grunnigan Ranch in a field bordering Yucca Creek.

Diospyros sp. (persimmon) is a $10 \mathrm{~m}$ tall deciduous fruit tree that has not been considered for ranking as an invasive species by CalEPPC. Animals and water probably disperse its seed. The directed surveys found a stand of vegetatively reproducing trees in Sequoia-Kings Canyon National Parks at Grunnigan Ranch in a field bordering Yucca Creek.

Ficus carica (edible fig) is a $7 \mathrm{~m}$ tall deciduous fruit tree that is ranked as one of the most invasive alien species by CalEPPC. Its CalFlora distribution indicates that it is common in southern California and in the Sacramento and San Joaquin Valleys (Appendix G). The directed surveys found this species in Sequoia-Kings Canyon National Parks in the North and Middle Forks of the Kaweah River and in Yucca Creek. $F$. carica forms dense thickets in riparian forests and streamside habitats and is very difficult to eradicate (Randall 2000). Its seed is dispersed in bird droppings, dung (Debussche and Isenmann 1994, Lisci and Pascini 1994) and probably by water. The seed will germinate only after it has passed through the gut of an animal or has been abraded by washing over rough surfaces (Lisci and Pascini 1994).

Juglans californica (California black walnut) is a $20 \mathrm{~m}$ tall deciduous nut tree that is native to California but is not native to any of the parks. The directed surveys found this species in Sequoia-Kings Canyon National Parks in Yucca Creek. The notes of the survey crew suggest that a single tree from a residual planting is creating a population of seedlings in Yucca Creek. It is wind pollinated and animals and water disperse its seed. It is also known to hybridize with Juglans regia (English walnut) (Hickman 1993), which is also growing nearby Yucca Creek.
Juglans regia (English walnut) is a $20 \mathrm{~m}$ tall deciduous nut tree that has not been considered for ranking as an invasive species by CalEPPC. Its CalFlora distribution indicates a patchy distribution in southern and central California (Appendix G). The directed surveys found this species in Sequoia-Kings Canyon National Parks in Yucca Creek. The notes of the survey crew suggest that it exists as a single tree from a residual planting. It is wind pollinated and animals and water probably disperse its seed. It is also known to hybridize with Juglans californica (California black walnut) (Hickman 1993), which grows near Yucca Creek.

Malus sylvestris (apple) is a $7 \mathrm{~m}$ tall deciduous fruit tree that has not been considered for ranking as an invasive species by CalEPPC. Its CalFlora distribution indicates a patchy distribution in southern and central California (Appendix G). The directed surveys found this species in Sequoia-Kings Canyon National Parks along Traugers Creek. The notes of the survey crew suggest that a single tree from a residual planting is creating a population of seedlings in Traugers Creek. Animals and water disperse its seed.

Morus alba (white mulberry) is a $10 \mathrm{~m}$ tall deciduous fruit tree that is considered to be a lesser invasive by the PNEPPC. Its CalFlora distribution indicates a patchy distribution California (Appendix G). The directed surveys found $M$. alba in Sequoia-Kings Canyon National Parks along the Colony Mill Road in a streambed and in the streambed of the Middle Fork of the Kaweah River. The seed of this species is dispersed in bird droppings (Ridley 1930, Debussche and Isenmann 1994) and probably by water.

Olea europaea (olive) is a $7 \mathrm{~m}$ tall evergreen fruit tree that has not been considered for ranking as an invasive species by CalEPPC. It is a highly invasive species in the Mediterraneantype climate areas of Australia. Its CalFlora distribution indicates that it has escaped from cultivation in southern California and in the Sacramento and San Joaquin Valleys (Appendix $\mathrm{G})$. The directed surveys found a stand of trees in Sequoia-Kings Canyon National Parks at 
Grunnigan Ranch growing along Old Hidden Springs Road. The seed of $O$. europaea is dispersed in bird droppings (Ridley 1930, Debussche and Isenmann 1994).

Prunus persica (peach) is a $7 \mathrm{~m}$ tall deciduous fruit tree that has not been considered for ranking as an invasive species by CalEPPC. The directed surveys found this species in SequoiaKings Canyon National Parks in the Crystal Cave parking lot. The survey notes indicate that two trees were residual plantings and two were saplings from seed. Animals and humans probably disperse the seed of this species.

Punica granatum (pomegranate) is a $5 \mathrm{~m}$ tall deciduous fruit tree that has not been considered for ranking as an invasive species by CalEPPC. Its CalFlora distribution indicates that it has a patchy distribution in southern California and in the San Joaquin Valley (Appendix G). The directed surveys found it in Sequoia-Kings Canyon National Parks along a footpath leading from the Ash Mountain Developed Area to the Kaweah River and at Grunningan Ranch. Animals and humans probably disperse its seed.

Rubus discolor (Himalayan blackberry) is an arched bramble that is ranked as one of the most invasive alien species by CalEPPC. Its CalFlora distribution indicates that it is widely distributed in California (Appendix G). The directed surveys found it in Sequoia-Kings Canyon National Parks at the Giant Forest Sewage Plant, Grunningan Ranch, Potwisha Campground, Redwood Creek, Yucca Creek and the Kaweah River. In Yosemite National Park it was found at El Portal, McCauley Ranch, Wawona and multiple locations in Yosemite Valley. Its seed is dispersed in bird droppings, dung and water (Parsons and Cuthbertson 1992, Hoshovsky 2000).

Rubus laciniatus (cut-leaved blackberry) is an arched bramble that is considered to be a lesser invasive by the PNEPPC. Its CalFlora distribution indicates that it has a patchy distribution along the north coast and in the Central Valley (Appendix G). The directed surveys found this species in Yosemite National Park at Lower Pines Campground, North Pines Campground, Wawona Campground and along the Meadow Loop Trail in Wawona. The seed of this species is probably dispersed in bird droppings, dung and water.

Vitis vinifera (cultivated grape) is a woody vine that has not been considered for ranking as an invasive species by CalEPPC. Its CalFlora distribution indicates that it has escaped cultivation along the coast and in the Central Valley (Appendix G). The directed surveys found $V$. vinifera in Sequoia-Kings Canyon National Parks growing in frequent dense patches in Yucca Creek and in Yosemite National Park in Yosemite Village. V. vinifera seed is dispersed in bird droppings (Ridley 1930, Debussche and Isenmann 1994) and probably by water.

\section{Localized Ornamentals With High Impact - Category 1 Species}

Ampelopsis arborea (peppervine) is a climbing deciduous vine with twining tendrils that has not been considered for ranking as an invasive species by CalEPPC. This species is established at Ash Mountain in Sequoia National Park. Birds probably disperse its seed.

Catalpa bignoides (common catalpa, Indian bean) is a $10 \mathrm{~m}$ tall deciduous tree that has not been considered for ranking as an invasive species by CalEPPC. This species is an ornamental, not yet naturalized, at Ash Mountain in Sequoia National Park. Animals and water probably disperse its seeds.

Cistus sp. (rock-rose) is a $1 \mathrm{~m}$ tall evergreen shrub not yet considered for ranking as an invasive species by CalEPPC. This species is an ornamental, not yet naturalized, at Ash Mountain in Sequoia National Park.

Coreopsis lanceolata (garden coreopsis) is a 0.3 to $0.6 \mathrm{~m}$ tall perennial that has not been considered for ranking as an invasive species by CalEPPC. Its CalFlora distribution indicates that it has escaped cultivation in Butte, Santa Cruz, and Sonoma Counties (Appendix G). The directed surveys found this species at El Portal in Yosemite National Park. The description of the seeds of this species in Hickman (1993) suggests that its seed is dispersed by adhering to animals and clothing. 
Digitalis purpurea (purple foxglove) is a $0.2 \mathrm{~m}$ tall perennial that is considered to be a lesser invasive by the PNEPPC. Its CalFlora distribution indicates that it has escaped cultivation along the coast and in the foothills bordering the Sacramento Valley (Appendix G). The directed surveys found this species in Sequoia-Kings Canyon National Parks at Cold Springs Campground, Giant Forest Developed Area in Eli's Paradise Meadow, Grant Grove Developed Area in the forest, Lodgepole Developed Area and at the former site of the Sunset Campground. This species was found in Yosemite National Park at Wawona. $D$. purpurea is extremely toxic (Fuller and McClintock 1986) and skin contact as well as smoke from burning leaves has caused injury to workers on control projects (Harris 2000). Its seed is dispersed in mud, wind, and vehicles (Hodkinson and Thompson 1997) and it remains viable in the soil for more than 5 years (Harris 2000).

Eucalyptus citriodora (lemon-scented gum) is a $30 \mathrm{~m}$ tall tree that has not been considered for ranking as an invasive species by CalEPPC. Its CalFlora distribution indicates that it has escaped from cultivation in San Diego County (Appendix G). This species is present in Sequoia-Kings Canyon National Parks at the Ash Mountain Park Boundary. The notes of the survey team indicate that the single tree at the site had been cut down but was stump sprouting. This seed of this species is dispersed by wind.

Genista monspessulana (French broom) is a 3 $\mathrm{m}$ tall evergreen shrub that is ranked as one of the most invasive alien species by CalEPPC. Its CalFlora distribution indicates that it is widespread along the coast and suggests that it is invading the areas around the Central Valley (Appendix G). The directed surveys found this species in Sequoia-Kings Canyon National Parks at the Ash Mountain Developed Area. The survey notes indicate that control efforts were in progress and that most plants appeared to be seedlings. All parts of this species are toxic (Hickman 1993). The seed of G. monspessulana is dispersed by ants, machinery, water, in bird droppings and mud (Pemberton and Irving 1990, Bossard 2000). Its seed remains viable in the soil for over 5 years (Bossard 2000).
Hedera helix (English ivy) is an evergreen woody vine or shrub that is ranked as a lesser invasive species by CalEPPC and is ranked as one of the most invasive alien species by the PNEPPC. Its CalFlora distribution indicates that it has escaped in many coastal counties and in the Sacramento Valley (Appendix G). The berries, leaves and sap of $H$. helix are toxic (Fuller and McClintock 1986). It is present in Sequoia-Kings Canyon National Parks at the Ash Mountain Developed Area and in Yosemite National Park at Yosemite Village. Its seed is dispersed in bird droppings (Gillham 1970, Debussche and Isenmann 1994).

Heteromeles arbutifolia (toyon) is a $5 \mathrm{~m}$ tall shrub or small tree that is native to California but is not native to the Kaweah River drainage. The notes of the survey crew indicate that it is naturalizing from plantings about the Ash Mountain Developed Area in Sequoia-Kings Canyon National Parks. Its seed is dispersed in bird droppings.

Iris sp. (iris) is an herbaceous perennial that spreads by seeds and vegetatively. The survey crew found a species of Iris escaping in the Lodgepole Developed Area of Sequoia-Kings Canyon National Parks. One plant was growing on the north side of the river on a steep slope adjacent to a large asphalt parking lot and another was found growing adjacent to a deserted government residence.

Leucanthemum vulgare (ox-eye daisy) is a 0.2 $\mathrm{m}$ to $0.5 \mathrm{~m}$ tall rhizomatous perennial that is ranked as a lesser invasive species by CalEPPC and is ranked as one of the most invasive alien species by PNEPPC. Its CalFlora distribution indicates that it is widespread in the northern half of the state (Appendix G). The directed surveys found it in Yosemite National Park at Foresta, North Pines Campground, Concession Stables (Yosemite Valley), Wawona, Yosemite West and Yosemite Lodge. L. vulgare seed is dispersed by adhering to animals, clothing, in dung, hay and wildflower seed mixes (Horthwath and Williams 1968, Fischer et al. 1996, Olsen and Wallander 1999). Its seed remains viable in the soil for at least 39 years (Toole and Brown 1946). 
Leucojum aestivum (summer snowflake) is a $0.5 \mathrm{~m}$ tall perennial that has not been considered for ranking as an invasive species by CalEPPC. The partial information provided by an abstracting service (CAB Abstracts) suggests that it is escaping cultivation in the northeastern U. S. but the referenced source material was not available. A description in the Sunset Western Garden Book (Hogan 1992), states that $L$. aestivum naturalizes under deciduous trees, in orchards, and on cool slopes. The directed surveys discovered it escaping in Sequoia-Kings Canyon National Parks at the Ash Mountain Developed Area. The survey notes state: "[h]undreds of plants grew about the Research Center in unwatered flowerbeds and in adjacent unwatered grassy areas. This species appears to reproduce sexually and asexually in this area."

Ligustrum sinense (Chinese privet) is a $7 \mathrm{~m}$ tall shrub or tree that requires more study according to CalEPPC. It is widely naturalized across the central and eastern U. S. and is a problem species in many nature preserves (Batcher 2000). The directed surveys found dozens of $L$. sinense hedges in Sequoia- Kings Canyon National Park growing about the Ash Mountain Developed Area. The seed of this species is dispersed in bird droppings and by water (Batcher 2000).

Nerium oleander (oleander) is a $4 \mathrm{~m}$ tall evergreen shrub that was considered but not ranked as an invasive species by CalEPPC. The directed surveys found a residual planting of this species in Sequoia-Kings Canyon National Parks at the Grunnigan Ranch near Yucca Creek. In California there is a widespread misperception that this species is adapted to dry conditions. In its native Mediterranean region $N$. oleander is an obligate riparian species that establishes on stream banks and on sandbanks in streambeds (Herrera 1991). In some areas in Sacramento County roadside populations of $N$. oleander are colonizing drainage ditches (Gerlach, personal observation). All parts of this species are very toxic (Fuller and McClintock 1986). Its seed is dispersed by water and wind (Herrera 1991).

Pyracantha angustifolia (firethorn) is a $4 \mathrm{~m}$ tall evergreen, thorny shrub that requires more study according to CalEPPC. Its CalFlora distribution indicates that it is escaping in coastal areas north of the San Francisco Bay (Appendix G). The directed surveys found this species naturalizing in Sequoia-Kings Canyon National Parks at the Ash Mountain Developed Area, Grunningan Ranch, Middle Fork of the Kaweah River and Sycamore Creek. The seed of this species is dispersed in bird droppings and in water (Ridley 1930, Debussche and Isenmann 1994).

Rudbeckia hirta (bristly coneflower, black-eyed susan) is a $0.3 \mathrm{~m}$ to $0.8 \mathrm{~m}$ tall annual to shortlived perennial that has not been considered for ranking as an invasive species by CalEPPC. This species is native to the prairies of the Midwestern United States (Hickman 1993) and should be considered a threat should it escape and invade meadows in California. Its CalFlora distribution indicates that it is escaping from cultivation in the Central Valley (Appendix G). The directed surveys discovered this species in Yosemite National Park at The Ahwahnee hotel.

Spartinum junceum (Spanish broom) is a $5 \mathrm{~m}$ tall shrub or tree that is ranked as a lesser invasive species by CalEPPC. Its CalFlora distribution indicates that it has naturalized along the coast and in the Sacramento Valley (Appendix G). The directed surveys found this species in Sequoia-Kings Canyon National Parks at the Ash Mountain Developed Area, along the Generals Highway and in the Middle Fork of the Kaweah River. The survey notes indicate that the Kaweah River population is periodically cut back by Park personnel. Its seed is dispersed by ants and water and is viable in the soil for more than 5 years (Nilsen 2000).

Tanacetum parthenium (feverfew) is a $1.0 \mathrm{~m}$ tall perennial that is ranked as one of the most invasive alien species by the PNEPPC. Its CalFlora distribution indicates that scattered populations are widely distributed about the state (Appendix G). The directed surveys found this species in Sequoia-Kings Canyon National Parks at the Grant Grove Developed Area and in Yosemite National Park at Wawona. This species is probably toxic and may cause contact dermatitis. Its seed is dispersed in mud and on vehicles (Hodkinson and Thompson 1997). 
Vinca major (greater periwinkle) is a sprawling shrub that roots at shoot nodes and has been ranked as a lesser invasive species by CalEPPC. Its CalFlora distribution indicates that it has escaped from cultivation along the coast and in the Sacramento Valley (Appendix G). The directed surveys found this species in Sequoia National Park at the Ash Mountain Developed Area, along the Generals Highway and in Potwisha Campground. It was discovered in Yosemite National Park at El Portal. This species is very difficult to eradicate and has caused problems in many natural areas and frequently invades moist, shady habitats (Bean and Russo 1988). In California it appears to be self-incompatible and to spread only from stem or root fragments (Bean and Russo 1988). The failure to produce viable seed due to selfincompatibility has been overcome by extensive selfing in other self-incompatible species (Hiscock 2000). This characteristic should not be relied upon to limit the spread of alien species.

\section{Priority Alien Grass Species}

\section{Category 1 Species}

The Pacific Northwest Alien Pest Plant Council (PNEPPC) ranked Agrostis gigantea as one of the most invasive alien species. Its CalFlora distribution is primarily along the north coast and northern Sierra Nevada. The outlier collections indicate that its can expand its range greatly in California (Appendix G). Currently, $A$. gigantea is known from Yosemite National Park, but survey notes indicate that it may also be present in Sequoia-Kings Canyon National Parks at the Columbine Picnic Area and in streams in the Grant Grove area near Wilsonia. In Yosemite National Park its distribution is limited to Yosemite Valley, Wawona and Foresta, although directed surveys of riparian areas might identify other populations. It is a 0.2 $\mathrm{m}$ to $1 \mathrm{~m}$ tall cool-season perennial grass with rhizomes up to $0.25 \mathrm{~m}$ long that forms an open sod over time. The typical habitats it invades are ditch banks, riparian areas and wet meadows, which it dominates through vegetative reproduction and seedling recruitment. It is dispersed in cow dung (Dore and Ranmond 1942, Welch 1985), probably in the dung of other animals and by water. The soil under established populations contains a large and 40 moderately persistent seed bank (Bekker et al. 2000). The literature contains no control methods appropriate for natural riparian areas and wet meadows. However, because this is an important forage species there is quite a lot of information about its biology in the literature (Anonymous 1972, Fergus and Buckner 1973, Alderson and Sharp 1995). Mechanical eradication is likely to be difficult and because of its association with wet habitats herbicide choices are very limited. Flaming with backpack units may be an option because of the reduced fire hazard in wet areas. If the species morphology and phenology are similar to other alien perennial grasses then management treatments during the boot stage are likely to be the most successful.

Arundo donax (giant reed) is ranked as one of the most invasive alien species by the California Alien Pest Plant Council (CalEPPC) and in some counties the species occupies nearly every drainage system (Kelly 1999). Its CalFlora distribution is widespread in both southern and northern California. It is found primarily in the coastal ranges, the Sacramento Valley and the foothills of the Sierra Nevada (Dudley 2000) (Appendix G). Currently, it appears to be expanding its range in the foothills of the southern Sierra Nevada. During the directed surveys $A$. donax was found only in SequoiaKings Canyon National Parks at the Ash Mountain Developed Area and in Sycamore Creek. The notes of the survey crew indicate that some eradication work was being carried out on the Sycamore Creek population in 1997. A. donax is a $2 \mathrm{~m}$ to $5 \mathrm{~m}$ tall, erect, perennial caneor reed-like grass, with creeping rhizomes that spread to form very dense stands (Dudley 2000). Interestingly, very little is known about the biology of this species, which has been used by humans for over 5,000 years (Hoshovsky 1986). As $A$. donax appears to reproduce only through the dispersal of rhizomes down stream or down slope, successful control requires that surveys be conducted upstream or up slope of all known populations to ensure that the site is not reinvaded (Stein and Vartanian 1997, Kelly 1999). The CalEPPC Team Arundo groups have developed control techniques. Team Arundo del Norte can be contacted through Tom Dudley, phone (510) 643-3021, or by email, tdudley@socrates.berkeley.edu. 
Bromus inermis (smooth brome) is ranked as one of the most invasive alien species by the PNEPPC. Its CalFlora distribution is primarily in northeastern California, and it appears to be expanding its range in central California (Appendix G). Currently, B. inermis is found only in Yosemite National Park, and its distribution is restricted to the southwestern portion of the park, Curry Village and Crane Flat. Because this species has only recently extended its range to central California, there is no information about its ability to invade park plant communities. However, its ability to invade and dominate similar plant communities is well established (Sather 1987, Tyser and Worley 1992, Grilz and Romo 1995, Willms and Quinton 1995, Blankespoor and May 1996). Also, because it is an important forage species, its habitat requirements have been well documented (Oakley 1924, Newell 1973, Looman 1976, Miller and Krueger 1976, Dewey and Plummer 1980, Miller et al. 1981, Casler and Carlson 1995, Vogel et al. 1996). B. inermis is a 0.5 to 1 meter tall, dense sod-forming, perennial cool-season grass that spreads from seed and rhizomes. It is more drought tolerant than other alien cool-season grasses and is also more tolerant of higher summer temperatures (Jung and Baker 1973). Some populations of $B$. inermis may become sod bound, but, if the species is growing in a mixture with legumes such as Medicago sativa (alfalfa) or Trifolium repens, the population will remain highly productive indefinitely (Casler and Carlson 1995). In addition to its ability to dominate native vegetation, $B$. inermis also may be a threat to the genetic identity of native perennial Bromus species. $B$. inermis has been shown to form fertile hybrids with $B$. pumpellianus in the Rocky Mountains (Elliot 1949) and new introductions of diploid genotypes by the USDA (Dewey and Plummer 1980) might increase the risk of hybridization with native perennial Bromus species. Control of $B$. inermis can be very difficult once it has established within stands of native grasses. However, its populations can be reduced through close mowing in early spring and late fall (Casler and Carlson 1995). Additionally, its rhizomes are not perennial and new rhizomes are initiated each spring from over-wintering shoots which can be killed by cutting them just below the soil surface in late fall (Oakley 1924). This morphological peculiarity may also render it susceptible to flaming in late fall when fire hazards are low.

Dactylis glomerata (orchard grass) is considered to be a lesser invasive by the PNEPPC. However, the forage and rangeland literature suggests that it has not been sown as a mid elevation range forage as widely as other alien cool-season grasses (Jung and Baker 1973). Also, along with Phleum pratense (cultivated timothy), it is one of the most sought after grass species by cattle (Miller and Krueger 1976) and may be somewhat limited by preferential grazing. D. glomerata is a $1 \mathrm{~m}$ to $1.3 \mathrm{~m}$ tall, cool season, open sod forming, perennial grass that forms dense populations than can persist for at least 20 years in competition with Poa pratensis (Tsuyuzaki and Kanda 1996). It can also tolerate much lower light levels than other alien perennial grass species (van Santen and Sleper 1996). The phenologies of the two major genotypes, northern European and Mediterranean, are very different. The northern European genotype is winter dormant and summer active while the Mediterranean genotype is winter active and summer dormant (van Santen and Sleper 1996). All of these factors suggest that the range expansion of $D$. glomerata has been dispersal limited and that the species is capable of dominating mesic, midelevation habitats in the parks. Its CalFlora distribution indicates that it is widely distributed in California (Appendix G). In Sequoia-Kings Canyon National Parks it is found at the Ash Mountain Developed Area, at the Columbine Picnic Area on a stream bank, Giant Forest Developed Area, Eli's Paradise Meadow, Round Meadow and Lodgepole Developed Area. It is found in Yosemite National Park throughout the Yosemite Valley and also at Tuolumne Concessions Stables, Merced Grove, Foresta, Wawona, Big Oak Flat Road and Tioga Road. A directed search of meadows and riparian areas will probably locate more populations. Shady meadows or riparian areas may be particularly susceptible to invasion by the northern European genotype. This means that it is particularly important to prevent the introduction of seed from areas where the northern European genotype has been sown - irrigated pastures in the foothills of the Sierra (Raguse et al. 1967) 
and rangeland and irrigated pastures in Idaho, Nevada, Oregon, and Washington. D. glomerata seed is dispersed by adhering to animals, floating on water, in cow dung (Ridley 1930, Kelley and Bruns 1975, Schmida and Ellner 1983, Mt. Pleasant and Schlather 1994, Fischer et al. 1996) and probably horse dung. $D$. glomerata is very responsive to increased levels of soil potassium and nitrogen and does especially well growing in mixtures with Medicago sativa or Trifolium repens (van Santen and Sleper 1996). Festuca arundinacea and Poa pratensis are only able to compete with it when nitrogen and potassium are limiting (Jung and Baker 1973). Its seed persists in the soil for at least 4 years (Lewis 1973). Its leaves support fungal endophytes (van Santen and Sleper 1996) but there are no reports in the literature implicating the alkaloids produced by the endophytes with animal health disorders as occurs when infected Festuca arundinacea is grazed. Nothing has been published on the control of $D$. glomerata and herbicide options will be very limited for populations growing in riparian areas.

Festuca arundinacea (tall fescue) is ranked as a lesser invasive species by CalEPPC. Its CalFlora distribution is primarily in coastal areas and in the Feather River and American River watersheds (Appendix G). It is found in Yosemite National Park at Lower River Campground and in Sequoia-Kings Canyon National Parks at the Ash Mountain Developed Area, Dorst Campground and along Cedar Grove Road. It appears to be expanding its range in the Sierra Nevada. $F$. arundinacea is an important forage species and has been sown extensively in irrigated pastures in California (Raguse et al. 1967) and rangeland and irrigated pastures in Idaho, Nevada, Oregon and Washington (Buckner and Cowan 1973, Sleper and West 1996). Many populations of this species host a fungal endophyte, which produces an alkaloid that causes severe health disorders in domestic grazing animals (Sleper and West 1996). Nothing is known about the effect of the toxin on wild herbivores. $F$. arundinacea is tolerant of wet soils and forms a dense turf (Buckner and Cowan 1973). Its seed persists in the soil for a short time, usually only one year (Lewis 1973). There is no information about control methods in the literature but there is a wealth of biological information in the agronomy and range literature (Buckner and Cowan 1973, Buckner and Bush 1979, Sleper and West 1996). Because this species is a common invader of riparian habitats herbicide options may be very limited.

Phalaris arundinacea (reed canary grass) is ranked as one of the most invasive alien species by the PNEPPC. Its CalFlora distribution is along the northern coast, the extreme northern portion of the state, the American River drainage and the San Joaquin Valley (Appendix G). This disjunct distribution suggests that $P$. arundinacea may be in the process of greatly expanding its range in California. $P$. arundinacea is found only in Sequoia-Kings Canyon National Parks at the Ash Mountain park boundary, Azalea Campground, Columbine Campground, along the Generals Highway, Grant Grove Developed Area (especially in the streams around Wilsonia) and Lodgepole Developed Area. Directed surveys along riparian areas in Yosemite National Park may discover populations in that park as well. There is some speculation that some native populations of $P$. arundinacea existed in the inland areas of the Pacific Northwest region, but this is now an academic issue due to extensive hybridization with introduced genotypes (Merigliano and Lesica 1998). In any case, it is clearly an alien species in the southern Sierra Nevada. $P$. arundinacea is a $0.8 \mathrm{~m}$ to $2 \mathrm{~m}$ tall perennial grass that spreads through seed and rhizomes and quickly forms a dense sod that eliminates all other species. There is no published data on the longevity of its seed in soil. The typical habitats it invades are ditch banks, riparian areas and wet meadows, which it dominates through vegetative reproduction and seedling recruitment. This species is dispersed in cow dung, bird droppings (Gillham 1970, Mt. Pleasant and Schlather 1994), probably also in the dung of other animals and by water. Control methods vary with habitat and co-occurring native species, and herbicide options are limited in riparian areas. 
Polypogon australis (Chilean beard grass) is a $0.1 \mathrm{~m}$ to $1 \mathrm{~m}$ tall perennial grass that has not been considered for ranking as an invasive species by CalEPPC. It is native to South America and the CalFlora collection data indicates that it invades riparian areas and lakeshores. Its CalFlora distribution indicates that it can greatly increase its range and that it was collected in the Big Oak Flat area in Tuolumne County in 1935 (Appendix G). The only population detected by the directed surveys is located in Sequoia-Kings Canyon National Parks at the Cedar Grove Pack Station. There is no other information about this species.

Polypogon interruptus (ditch beard grass) is a $0.5 \mathrm{~m}$ to $0.9 \mathrm{~m}$ tall perennial grass that has not been considered for ranking as an invasive species by CalEPPC. It is native to South America, and the CalFlora collection data indicates that it invades riparian areas. Its CalFlora distribution indicates that it is widespread (Appendix G) but the only population detected by the directed surveys was in Sequoia-Kings Canyon National Parks on the banks of Yucca Creek 100 meters upstream of the Old Hidden Springs Road.

\section{Category 2 Species}

Less detailed information is presented for Category 2 species due to a paucity of available information; because of their lesser impacts; and given the large numbers of Category 1 species, because of the reduced likelihood that management efforts would be directed at them. These are species to monitor for changes in their distributions and ecological impacts. Their status should be reevaluated periodically as part of an adaptive management plan using data from the parks and data generated elsewhere.

Sequoia-Kings Canyon National Parks only: Echinochloa crus-galli (barnyard grass), Festuca pratensis (meadow fescue), Phalaris minor, Phalaris paradoxa, Piptatherum miliaceum (smilo grass), Polypogon monspeliensis (annual beard grass), Sorghum halepense (johnsongrass), and Vulpia bromoides (brome fescue).

Yosemite National Park only: None.
Both Yosemite National Park and SequoiaKings Canyon National Parks: Holcus lanatus (common velvet grass), Lolium perenne, Phleum pratense, Poa bulbosa, and Poa compressa (Canadian bluegrass).

\section{Category 3 Species}

Bromus tectorum (cheat grass) is a $0.05 \mathrm{~m}$ to $0.4 \mathrm{~m}$ tall annual grass that is ranked as one of the most invasive alien species by the CalEPPC. This species has caused extensive ecological harm in the Intermountain Basin and Range region of the western United States by reducing fire return intervals and creating a deep thatch (Upadhyaya et al. 1986, Billings 1990). Its CalFlora distribution indicates that $B$. tectorum is widely distributed across the state (Appendix $\mathrm{G})$. It is widely distributed in both parks at altitudes between 609 and 2,438 m (2,000-8,000 $\mathrm{ft}$ ). While many of the populations are restricted to roadsides, trailsides and disturbed areas, many other populations exist in undisturbed open areas on well-drained soils. Quadrat data from an undisturbed Pinus ponderosa/Calocedrus decurrens forest in Sequoia-Kings Canyon National Parks indicated that B. tectorum occurred in only 3 percent of the quadrats and its maximum cover was only 1 percent. This low level of cover in intact forest is similar to that reported for a Pinus ponderosa forest in eastern Washington where $B$. tectorum only attained high cover in canopy gaps, and the individuals outside of the gaps produced only 1 seed on average (Pierson and Mack 1990b, a). The authors of that study concluded that $B$. tectorum could not successfully invade those forests without a substantial increase in the size and frequency of canopy disturbance. The distribution of $B$. tectorum in the parks and the published studies suggest that $B$. tectorum is likely to have the greatest impact on native species that require persistent canopy gaps, on native ephemeral species that persist in the soil seed bank until a major disturbance occurs and on the seedlings of perennial and woody species. $B$. tectorum seed is adhesive and is dispersed on footwear and on fur. It is also dispersed in dung, in hay and on vehicles (Lehrer Jr. and Tisdale 1956, Schmida and Ellner 1983, Mosley et al. 1999). Its seed viability in soil is less than 5 years (Upadhyaya et al. 1986). 
Poa pratensis (Kentucky bluegrass) is a $0.2 \mathrm{~m}$ to $0.7 \mathrm{~m}$ tall perennial grass that is ranked as one of the most invasive alien species by the PNEPPC and is considered to be invasive in wet to moist meadows in the Sierra Nevada (Menke et al. 1996). There is speculation that $P$. pratensis ssp. agassizensis may be a native species in the Rocky Mountains (Wedin and Huff 1996) and possibly in the Sierra Nevada, but the directed surveys at both parks detected only the alien $P$. pratensis ssp. Pratensis, which is also the only subspecies present in the park floras. Its CalFlora distribution indicates that it has a wide distribution in California (Appendix G). The directed-survey data indicate that this species is widely distributed in both parks and is displacing native species at some locations. A study in the Rocky Mountains found that Poa palustris (fowl bluegrass) is a more aggressive alien invader of ungrazed riparian areas and wet meadows and speculated that it may be frequently misidentified as $P$. pratensis (Schultz and Leininger 1990). Misidentification of the two species is also common in California (Menke et al. 1996). The CalFlora distribution indicates that $P$. palustris is widely distributed in the Sierra Nevada (Appendix G). P. pratensis seed is dispersed by adhering to animals and humans, in cow dung (Dore and Ranmond 1942, Welch 1985, Mt. Pleasant and Schlather 1994, Fischer et al. 1996), and probably in horse dung. Its seed is viable in soil for at least 4 years (Lewis 1973), and it forms a persistent seed bank (Tsuyuzaki and Kanda 1996). When grassland containing $P$. pratensis is grazed, the species responds with a 10-fold increase in seed production (Willms and Quinton 1995). $P$. pratensis spreads vegetatively by rhizomes to form a dense sod. It is more tolerant of continuous, close grazing than any other coolseason grass and is especially tolerant of close grazing by horses and sheep (Wedin and Huff 1996). In the mountains of Oregon it frequently invades lightly grazed meadows of native grasses and clear-cuts sown with various cool season perennial grass mixtures (Krueger and Winward 1974, Miller and Krueger 1976, Miller et al. 1981, Holecheck et al. 1982, Kauffman et al. 1983).

\section{Part IV. Additional Recommendations}

The field data and literature that were analyzed in producing this report suggest that both additional data and new park procedures are required for the effective management of alien species. These additional requirements can be grouped into three general categories.

\section{Survey}

1) Survey all low and mid elevation riparian areas in both parks and survey high elevation riparian areas near private inholdings or areas where domesticated grazing animals are either permitted or trespass.

2) Survey all meadows to determine the extent of the Poa pratensis invasion and the presence of Poa palustris.

3) Survey additional disturbed areas, including road and trail corridors, in all three parks to further document present distributions

4) Survey the Siberian Outpost and other dry meadows as well as the Big Whitney Meadow in Inyo National Forest periodically to ensure that alien species adapted to the Basin and Range region are not invading Sequoia National Park.

5) Survey the areas within $100 \mathrm{~m}$ of private inholdings, farther if alien species extend farther.

6) Survey roadsides and trails of National Forests and other areas with roads or trails that abut the parks.

7) Maintain all of the survey data in a Geographic Information System.

\section{Research}

1) Conduct research on the Category 3 species to determine their extent, growth rates, dispersal vectors and impacts on native species.

2) Model the invasion potential of Category 1 species.

3) Research on the impact of fire restoration to invasives, such as Bromus tectorum. 


\section{Procedural}

1) Establish rapid response procedures for alien species management.

2) Establish procedures for managing areas of natural disturbances to ensure that they are not invaded by alien species.

3) Establish protocols for recording, mapping and monitoring disturbances caused by construction equipment, earth moving equipment, field crews, etc.

4) Require that all pack animals used in the parks be fed certified weed-free feed.

5) Eliminate the grazing by domestic animals of areas invaded by nonnative Kentucky bluegrass (Poa pratensis ssp. pratensis) to avoid contributing to its spread

6) Require the use of native grasses in lawns and prohibit the introduction of herbicideresistant cultivars and invasive cultivars.

\section{Part V. Literature Cited}

Aarssen, L.W., Hall, I.V., and Jensen, K.I.N., 1986, The biology of Canadian weeds. 76 . Vicia angustifolia L., $V$. cracca L., $V$. sativa L., $V$. tetrasperma (L.) Schreb. and $V$. villosa Roth. Canadian Journal of Plant Science 66, p. 711-737.

Alderson, J., and Sharp, W.C., 1995, Grass Varieties in the United States. Lewis Publishers, New York.

Anonymous. 1992, Guidelines for Coordinated Management of Noxious Weeds in the Greater Yellowstone Area. U.S. Department of Interior and U.S. Department of Agriculture. Washington, D.C.

Anonymous. 1972, Grass Varieties in the United States. Agriculture Handbook No. 170. Agricultural Research Service, U.S. Department of Agriculture, Washington, D.C.

Apfelbaum, S.I., and Sams, C.E., 1987, Ecology and control of reed canary grass (Phalaris arundinacea L.). Natural Areas Journal 7, p. $69-74$.

Asay, K.H., Dewey, D.R., Horton, W.H., Jensen, K.B., Currie, P.O., Chatterton, N.J., Hansen, W.T., II, and Carlson, J.R., 1991, Registration of "Newhy" RS hybrid wheatgrass. Crop Science 31, p. 1384-1385.

Batcher, M.S., 2000, Element stewardship abstract for Ligustrum spp. (privet). The Nature Conservancy, Arlington, Va.
Bean, C., and Russo, M.J., 1988, Element stewardship abstract for Vinca major (periwinkle): The Nature Conservancy, Arlington, $\mathrm{Va}$.

Bekker, R.M., Verweij, G.L., Bakker, J.P., and Fresco, L.F.M., 2000, Soil seed bank dynamics in hayfield succession: Journal of Ecology 88, p. 594-607.

Bellue, M.K., 1945, Weed seed handbook, series III: California Department of Agriculture Bulletin 34, p. 116-123.

Billings, W.D., 1990, Bromus tectorum, a biotic cause of ecosystem impoverishment in the Great Basin, in Woodwell, G.M., ed. The Earth in Transition: Patterns and Processes of Biotic Impoverishment. Cambridge University Press, New York, NY, p. 301322.

Blankespoor, G.W., and May, J.K., 1996, Alien smooth brome (Bromus inermis Leyss.) in a tallgrass prairie remnant: seed bank, seedling establishment, and growth dynamics: Natural Areas Journal 16, p. 289294.

Bossard, C.C., 2000, Genista monspessulana (L.) Johnson, in Bossard, C.C., Randall, J., and Hoshovsky, M., eds. Invasive Plants of California's Wildlands: University of California Press, Berkeley, Calif., p. 203208.

Bossard, C.C., and Lichti, R., 2000, Carduus pycnocephalus L, in Bossard, C.C., Randall, J., and Hoshovsky, M., eds. Invasive Plants of California's Wildlands:University of California Press, Berkeley, Calif., p. 8690.

Brede, D., 2000, Four unconventional grasses to know and love: TurfGrass Trends 8, p. 9-14.

Brock, J.H., 1994, Tamarix spp. (Salt Cedar), An invasive exotic woody plant in arid and semi- arid riparian habitats of Western USA, in de Waal, L.C., Child, L.E., Wade, P.M., and others, eds. Ecology and Management of Invasive Riverside Plants. John Wiley and Sons Ltd., New York, NY, p. 27-44.

Buckner, R.C., and Bush, L.P., eds., 1979, Tall Fescue. Agronomy Monograph 20. American Society of Agronomy, Madison, Wis.

Buckner, R.C., and Cowan, J.R., 1973, The Fescues, in Heath, M.E., Metcalfe, D.S., and Barnes, R.F., eds. Forages: The Science of Grassland Agriculture: Iowa State University Press, Ames, Iowa, p. 297-306. 
CalFlora, Information on California plants for education, research and conservation, 2000. [http://www.calflora.org/. Accessed: May 14, 2000 and Jan. 30, 2001] Berkeley, Calif.

CalEPPC, 1999, Exotic Pest Plants of Greatest Ecological Concern in California: California Exotic Pest Plant Council www.caleppc.org/info/plantlist.html.

Calihan, R.H., Prather, T.S., and Northam, F.E., 1993, Longevity of yellow starthistle (Centaurea solstitialis) achenes in soil: Weed Technology 7, p. 33-35.

Carrier, L., and Bort, K.S., 1916, The history of Kentucky blue grass and white clover in the United States: Journal of the American Society of Agronomy 8, p. 256-266.

Casler, M.D., and Carlson, I.T., 1995, Smooth bromegrass, in Barnes, R.F., Miller, D.A., and Nelson, C.J., eds., Forages: An Introduction to Grassland Agriculture. Iowa State University Press, Ames, Iowa, 313 p.

Clements, D.R., Upadhyaya, M.K., and Bos, S.J., 1999, The biology of Canadian weeds. 110. Tragopogon dubius Scop., Tragopogon pratensis L., and Tragopogon porrifolius L. Canadian Journal of Plant Science 79, p. 153-163.

Cowie, I.D., and Werner, P.A., 1993, Alien plant species invasive in Kakadu National Park, tropical northern Australia. Biological Conservation. 63, p. 127-135.

D'Antonio, C.M. and Vitousek, P.M., 1992, Biological invasions by exotic grasses, the grass-fire cycle and global change: Annual Review of Ecology and Systematics 23, p. 63-87.

Davis, E.S., Fay, P.K., Chincoine, T.K., and Lacey, C.A., 1993, Persistence of spotted knapweed (Centaurea maculosa) seed in soil. Weed Science 41, p. 57-61.

Debussche, M., and Isenmann, P., 1994, Birddispersed seed rain and seedling establishment in patchy Mediterranean vegetation: Oikos 69, p. 414-426.

DeFarrari, C.M., and Naiman, R.J., 1994, A multi-scale assessment of the occurrence of exotic plants on the Olympic Peninsula, Washington: Journal of Vegetation Science 5, p. 247-258.

Dewey, D.R., and Plummer, A.P., 1980, New collections of range plants from the Soviet Union: Journal of Range Management 33, p. 89-94.
DiTomaso, J.M., and Gerlach, J.D., Jr., 2000, Centaurea solstitialis L, in Bossard, C.C., Randall, J., and Hoshovsky, M., eds. Invasive Plants of California's Wildlands. University of California, Berkeley, Calif., p. 101-106

Dore, W.G., and Ranmond, L.C., 1942, Pasture studies XXIV: viable seeds in pasture soil and manure. Scientific Agriculture 23, p. 6979.

Dudley, T.L., 2000, Arundo donax L., in Bossard, C.C., Randall, J., and Hoshovsky, M., eds., Invasive Plants of California's Wildlands: University of California Press, Berkeley, Calif., p. 53-58.

Ebdon, J.S., 2000, Freeze-stress resistance: TurfGrass Trends 8, p. 1-8.

Edgar, J.A., 1994, Toxins in temperate grasses implications and solutions: New Zealand Journal of Agricultural Research 37, p. 341347.

Elliot, F.C., 1949, Bromus inermis and $B$. pumpellianus in North America: Evolution 3, p. 142-149.

Evans, M.W., 1916, Some effects of legumes on associated nonlegumes: Journal of the American Society of Agronomy 8, p. 348357.

Evans, R.A., Young, J.A., and Hawkes, R., 1979, Germination characteristics of Italian thistle (Carduus pycnocephalus) and slenderflower thistle (Carduus tenuiflorus): Weed Science 27, p. 327-332.

Fergus, E.N., and Buckner, R.C., 1973, The bluegrasses and redtop, in Heath, M.E., Metcalfe, D.S., and Barnes, R.F., eds., Forages: The Science of Grassland Agriculture: Iowa State University Press, Ames, Iowa, p. 243-253.

Fischer, S.F., Poschlod, P. and Beinlich, B., 1996, Experimental studies on the dispersal of plants and animals on sheep in calcareous grasslands: Journal of Applied Ecology 33, p. 1206-1222.

Fuller, T.C., and McClintock, E., 1986, Poisonous Plants of California: University of California Press, Berkeley, Calif.

Gillham, M.E., 1970, Seed dispersal by birds, in Perring, F., ed. The Flora of a Changing Britain. Classey, E.W., Ltd., Middlesex, UK. 
Graf, W.L., 1978, Fluvial adjustments to the spread of tamarisk in the Colorado Plateau region: Geological Society of America Bulletin 89, p. 491-501.

Gray, M., and Michael, P.W., 1986, List of plants collected at the old Flemington Saleyards, Sydney, New South Wales: Plant Protection Quarterly 1, p. 135-143.

Grilz, P.L., and Romo, J.T., 1995, Management considerations for controlling smooth brome in fescue prairie: Natural Areas Journal 15, p. 148-156.

Harmon, G.W., and Keim, F.D., 1934, The percentage and viability of weed seeds recovered in the feces of farm animals and their longevity when buried in soil: Journal of the American Society of Agronomy 26, p. $762-767$.

Harris, S.A., 2000, Digitalis purpurea L. in Bossard, C.C., Randall, J.A., and Hoshovsky, M., eds. Invasive Plants of California's Wildlands: University of California Press, Berkeley, Calif., p. 158161.

Harrison, R.D., Page, C.N.J., Curto, R.J., Asay, N.K.H., Jensen, K.B., and Horton, W.H., 1996, Competition, Biodiversity, Invasion, and Wildlife Use of Selected Introduced Grasses in the Columbia and Great Basins. No. 155, Utah Experimental Station, Logan, Utah.

Haultain, S.A., Graber, D.M., and Heise, K., 1988, Preliminary Descriptions of the Natural Plant Communities of Sequoia and Kings Canyon National Parks: Unpublished Manuscript, National Park Service Files, Sequoia and Kings Canyon National Parks, Calif., $13 \mathrm{p}$.

Herrera, J., 1991, The reproductive biology of a riparian Mediterranean shrub, Nerium oleander L. (Apocynaceae): Botanical Journal of the Linnean Society 106, p. 147172.

Hickman, J.C., ed., 1993, The Jepson Manual: Higher Plants of California: University of California Press, Berkeley, Calif., 1400 p.

Hiebert, R.D., and Stubbendieck, J., 1993, Handbook for Ranking Exotic Plants for Management and Control: Department of Interior, National Park Service, Natural Resources Publication NPS/NRMWRO/NRR-93/08. Denver, Colo., 29 p.
Hiscock, S.J., 2000, Genetic control of selfincompatibility in Senecia squalidus L. (Asteraceae) a successful colonizing species: Heredity 85, p. 10-19.

Hodkinson, D.J, and Thompson, K., 1997, Plant dispersal: the role of man: Journal of Applied Ecology 34, p. 1484-1496.

Hogan, E.L., ed., 1992, Sunset Western Garden Book: Sunset Publishing Corporation, Menlo Park, Calif.

Holecheck, J.L., Vavra, M., and Skovlin, J., 1982, Cattle diet and daily gains on a mountain riparian meadow in northeastern Oregon: Journal of Range Management 35, p. 745-747.

Horthwath, S.E., and Williams, J.T., 1968, Biological flora of the British Isles. Chrysanthemum [Leucanthemum] leucanthemum L. [vulgare Lam.]: Journal of Ecology 56, p. 585-595.

Hoshovsky, M., 1986, Element stewardship abstract for Arundo donax (giant reed): The Nature Conservancy, Arlington, Va.

Hoshovsky, M., 2000, Rubus discolor Weihe \& Nees, in Bossard, C.C., Randall, J., and Hoshovsky, M., eds. Invasive Plants of California's Wildlands: University of California Press, Berkeley, Calif., p. 277281.

Jung, G.A., and Baker, B.S., 1973, Orchardgrass, in Heath, M.E., Metcalfe, D.S., and Barnes, R.F., eds. Forages: The Science of Grassland Agriculture: Iowa State University Press, Ames, IA, p. 285296.

Kauffman, J.B., Krueger, W.C., and Vavra, M., 1983, Effects of late season cattle grazing on riparian plant communities: Journal of Range Management 36, p. 685-691.

Keeley, J.E., 1992, Nerium oleander L. (Apocynaceae). Madroño 39, 157 p.

Kehr, W.R., Rumbaugh, M.D., Semeniuk, G., Barnes, D.K., Frosheiser, F.I., and Manglitz, G.R., 1984, Registration of Daneb I, Daneb II BW1, and Daneb I P2, alfalfa germplasm with multiple pest resistance: Crop Science 24, 1001 p.

Kelley, A.D., and Bruns, V.F., 1975, Dissemination of weed seeds by irrigation water: Weed Science 23, p. 486-493.

Kelly, M., 1999, Roundup of Arundo projects reveals commitment, strategic weaknesses: CalEPPC News 7, p. 4-9. 
Klinger, R., 2000, Foniculum vulgare Miller. in Bossard, C.C., Randall, J., and Hoshovsky, M., eds. Invasive Plants of California's Wildlands: University of California Press, Berkeley, Calif., p. 198-202.

Krueger, W.C., and Winward, A.H., 1974, Influence of cattle and big game grazing on understory structure of a douglasfirponderosa pine-Kentucky bluegrass community: Journal of Range Management 27, p. 450-453.

Legendre, P., and Legendre, L., 1998, Numerical Ecology, 2nd English edition: Elsevier, New York, NY.

Lehrer, W.P., Jr., and Tisdale, E.W., 1956, Effect of sheep and rabbit digestion on the viability of some range plant seeds: Journal of Range Management 9, p. 118-122.

Lewis, J., 1973, Longevity of crop and weed seeds: survival after 20 years in soil: Weed Research 13, p. 179-191.

Lisci, M., and Pascini, E., 1994, Germination ecology of the druplets of the fig (Ficus carica L.): Botanical Journal of the Linnean Society 114, p. 133-146.

Looman, J., 1976, Productivity of permanent bromegrass pastures in the parklands of the prairie provences: Canadian Journal of Plant Science 56, p. 829-835.

Lovich, J., 2000, Tamarix ramosissima Ledeb., Tamarix chinensis, Tamarix gallica, Tamarix parviflora, in Bossard, C.C., Randall, J., and Hoshovsky, M., eds. Invasive Plants of California's Wildlands: University of California Press, Berkeley, Calif., p. 312-317.

Lowe, C.C., Marble, V.L., and Rumbaugh, M.D., 1972, Adaptation, varieties, and usage, in Hanson, C.H., ed. Alfalfa Science and Technology: American Society of Agronomy, Madison, Wis., p. 391-411.

Macdonald, I.A.W., Graber, D.M., DeBenedetti, S., Groves, R.H. and Fuentes, E.R., 1988, Introduced species in nature reserves in Mediterranean-type climatic regions of the world: Biological Conservation 44, p. 37-66.

Malo, J.E., and Suarez, F., 1995, Herbivorous mammals as seed dispersers in a Mediterranean dehesa: Oecologia 104, p. 246-255.

McClay, A.S., and Ophel, K.M., 1993, Toxigenic Calvibacter/Anguina associations infecting grass seedheads: Annual Review of Phytopathology 31, p. 151-167.
Menke, J.M., Davis, C., and Beesley, P., 1996, Rangeland assessment, in Sierra Nevada Ecosystem Project: Final Report to Congress, Vol. III: University of California, Centers for Water and Wildlife Resources, Davis, Calif., p. 901-972.

Merigliano, M.F., and Lesica, P., 1998, The native status of reed canarygrass (Phalaris arundinacea L.) in the inland northwest, USA: Natural Areas Journal 18, p. 223-230.

Miller, R.F., and Krueger, W.C., 1976, Cattle use on summer foothill rangelands in northeastern Oregon: Journal of Range Management 29, p. 367-371.

Miller, R.F., Krueger, W.C., and Vavra, M., 1981, Deer and elk use on foothill rangelands in northeastern Oregon: Journal of Range Management 34, p. 201-204.

Moore, P.E., 1993, Preliminary Descriptions of the Terrestrial Natural Communities of Yosemite National Park, California. Unpublished Manuscript, Yosemite Research Center Files, Yosemite National Park, Calif., $42 \mathrm{p}$.

Mosley, J.C., Bunting, S.C., and Manoukian, M.E., 1999, Cheatgrass, in Sheley, R.L., and Petroff, J.K., eds. Biology and Management of Noxious Rangeland Weeds: University of Oregon Press, Corvalis, Oreg., p. 175-188.

Mt. Pleasant, J., and Schlather, K.J., 1994, Incidence of weed seed in cow (Bos sp.) manure and its importance as a weed source for cropland: Weed Technology 8, p. 304310.

Myers, W.M., and Chilton, S.J.P., 1941, Correlated studies of winterhardiness and rust reaction of parents and inbred progenies of orchard grass and timothy: American Society of Agronomy Journal 33, p. 215220.

National Park Service, 1996, Preserving Our Natural Heritage: A Strategic Plan for Managing Invasive Nonnative Plants on National Park System Lands: U.S. Department of the Interior, National Park Service, Washington, D.C., 16 p.

National Park Service, 2000, Final Yosemite Valley Plan Supplemental Environmental Impact Statement. Volume IA, Purpose and Need, Alternatives, Affected Environment: U.S. Department of Interior, National Park Service, Yosemite National Park, Yosemite, Calif., 524 p. 
APPENDICES 
Schmida, A., and Ellner, S., 1983, Seed dispersal on pastoral grazers in open Mediterranean chaparral, Israel: Israel Journal of Botany 32, p. 147-159.

Schultz, T.T., and Leininger, W.C., 1990, Differences in riparian vegetation structure between grazed areas and exclosures: Journal of Range Management 43, p. 295299.

Sheley, R.L., Jacobs, J.S., and C.M.L., 1999, Spotted knapweed, in Sheley, R.L., and Petroff, J.K., eds. Biology and Management of Noxious Rangeland Weeds: University of Oregon Press, Corvalis, Oreg.

Sleper, D.A., and West, C.P., 1996, Tall fescue, in Moser, L.E., Buxton, D.R., and Casler, M.D., eds. Cool-Season Forages: American Society of Agronomy, Madison, Wis., p. 471-502.

St John-Sweeting, R.S., and Morris, K.A., 1990, Seed transmission through the digestive tract of the horse, in Proceedings of the $9^{\text {th }}$ Australian Weeds Conference: South Australia, Australia, p. 137-139.

Stein, E.D., and Vartanian, V., 1997, Killing the beast: a cooperative approach for control of Arundo donax in the Santa Ana River watershed: CalEPPC News 5, p. 4-6.

Toole, E.H., and Brown, E., 1946, Final results of the Duvel buried seed experiment: Journal of Agricultural Research 72, p. 201210.

Tsuyuzaki, S., and Kanda, F., 1996, Revegetation patterns and seed bank structure on abandoned pastures in northern Japan: American Journal of Botany 83, p. 1422-1428.

Turkington, R.A., Cavers, P.B., and Rempel, E., 1978, The biology of Canadian weeds. 29. Melilotus alba Desr. and M. officinalis (L.) Lam: Canadian Journal of Plant Science 58, p. 523-537.

Tyser, R.W., and Worley, C.A., 1992, Alien flora in grasslands adjacent to road and trail corridors in Glacier National Park, Montana (U.S.A.): Conservation Biology 6, p. 253262.

Upadhyaya, M.K., Turkington, R., and Mcllvride, D., 1986, The biology of Canadian weeds. 75. Bromus tectorum L.: Canadian Journal of Plant Science 66, p. 689-709.
Vankat, J.L., 1982, A gradient perspective on the vegetation of Sequoia National Park, California: Madroño 29, p. 200-214.

van Santen, E., and Sleper, D.A., 1996, Orchardgrass, in Moser, L.E., Buxton, D.R., and Casler, M.D., eds. Cool-Season Forages: American Society of Agronomy, Madison, Wis., p. 503-534.

Vitousek, P.M., and Walker, L.R., 1989, Biological invasion by Myrica faya in Hawaii: plant demography, nitrogen fixation, ecosytem effects: Ecological Monographs 59, p. 247-265.

Vogel, K.P., Moore, K.J., and Moser, L.E., 1996, Bromegrasses, in Moser, L.E., Buxton, D.R., and Casler, M.D., eds. CoolSeason Forages: American Society of Agronomy, Madison, Wis., p. 535-567.

Wallender, R.T., Olson, B.E., and Lacey, J.R., 1995, Spotted knapweed seed viability after passing through sheep and mule deer: Journal of Range Management 48.

Warner, P.J., 2000, Mentha pulegium L., in Bossard, C.C., Randall, J., and Hoshovsky, M., eds. Invasive Plants of California's Wildlands: University of California Press, Berkeley, Calif., p. 240-244.

Warren, J.M., 2000, The role of white clover in the loss of diversity in grassland habitat restoration: Restoration Ecology 8, p. 318323.

Watson, A.K., and Renney, A.J., 1974, The biology of Canadian weeds. 6. Centaurea diffusa and C. maculosa: Canadian Journal of Plant Science 54, p. 687-701.

Weaver, S.E., and Riley, W.R., 1982, The biology of Canadian weeds. 53. Convolvulus arvensis L.: Canadian Journal of Plant Science 62, p. 461-472.

Wedin, W.F., and Huff, D.R., 1996, Bluegrass, in Moser, L.E., Buxton, D.R., and Casler, M.D., eds. Cool-Season Forage Grasses: American Society of Agronomy, Madison, Wis., p. 665-690.

Weiss, J., and J. Sagliocco. 2000. Horehound (Marrubium vulgare): a comparison between European and Australian populations. Plant Protection Quarterly 15:18-20. 
Welch, D. 1985. Studies in the grazing of heather moorland in north-east Scotland. IV. Seed dispersal and plant establishment in dung. Journal of Applied Ecology 22:461472.

Willms, W. D., and D. A. Quinton. 1995. Grazing effects on germinable seeds on the fescue prairie. Journal of Range Management 48:423-430.
Wipff, J. K., and C. Rose-Fricker. 2000. Determining gene flow of transgenic creeping bentgrass and gene transfer to other bentgrass species. Diversity 16:36-39.

Young, J. A., E. Martens, and N. E. West. 1992. Germination of bur buttercup seeds. Journal of Range Management 45:358-362.

Zamora, D. L., and J. P. Olivarez. 1994. The viability of seeds in feed pellets. Weed Technology 8:148-153. 



Appendix A. Sequoia-Kings Canyon National Parks - Priority alien species by species and by site.

\begin{tabular}{|c|c|c|c|c|}
\hline Site & Alien Species & Site & Alien Species & Site Type \\
\hline Ash Mountain Developed Area & Ampelopsis arborea & Ash Mountain Developed Area & Ampelopsis arborea & Development \\
\hline Ash Mountain Developed Area & Arundo donax & Ash Mountain Developed Area & Arundo donax & Development \\
\hline Sycamore Creek, M. F. Kaweah & Arundo donax & Ash Mountain Developed Area & Carduus pycnocephalus & Natural \\
\hline Sunset Campground & Bromus tectorum & Ash Mountain Developed Area & Cistus & Development \\
\hline Azalea Campground & Bromus tectorum & Ash Mountain Developed Area & Dactylis glomerata & Development \\
\hline Big Stump Picnic Area & Bromus tectorum & Ash Mountain Developed Area & Festuca arundinacea & Development \\
\hline Buckeye Campground & Bromus tectorum & Ash Mountain Developed Area & Festuca pratensis & Development \\
\hline Camp Conifer & Bromus tectorum & Ash Mountain Developed Area & Genista monspessulana & Development \\
\hline Cedar Grove Market and Lodge & Bromus tectorum & Ash Mountain Developed Area & Hedera helix & Development \\
\hline Cedar Grove Pack Station & Bromus tectorum & Ash Mountain Developed Area & Heteromeles arbutifolia & Development \\
\hline Cedar Grove Road & Bromus tectorum & Ash Mountain Developed Area & Lathyrus latifolius & Development \\
\hline Colony Mill Road & Bromus tectorum & Ash Mountain Developed Area & Leucojum aestivum & Development \\
\hline Crystal Cave Parking Lot & Bromus tectorum & Ash Mountain Developed Area & Ligustrum sinense & Development \\
\hline Giant Forest Sewage Plant & Bromus tectorum & Ash Mountain Developed Area & Medicago sativa & Development \\
\hline High Sierra Trail & Bromus tectorum & Ash Mountain Developed Area & Melilotus indica & Development \\
\hline Lewis Creek Trail & Bromus tectorum & Ash Mountain Developed Area & Oxalis pes-caprae & Development \\
\hline Lodgepole Campground & Bromus tectorum & Ash Mountain Developed Area & Poa bulbosa & Development \\
\hline Middle Fork Flume & Bromus tectorum & Ash Mountain Developed Area & Poa pratensis & Development \\
\hline Milk Ranch Lookout & Bromus tectorum & Ash Mountain Developed Area & Polypogon monspeliensis & Development \\
\hline Moraine Campground & Bromus tectorum & Ash Mountain Developed Area & Punica granatum & Development \\
\hline Oriole Lake Meadow & Bromus tectorum & Ash Mountain Developed Area & Pyracantha angustifolia & Development \\
\hline Oriole Lake Road & Bromus tectorum & Ash Mountain Developed Area & Spartium junceum & Development \\
\hline Rae Lakes Loop Trail & Bromus tectorum & Ash Mountain Developed Area & Trifolium repens & Development \\
\hline Red Fir Maintenance Area & Bromus tectorum & Ash Mountain Developed Area & Verbascum thapsus & Development \\
\hline Redwood Creek, Mineral King & Bromus tectorum & Ash Mountain Developed Area & Vicia sativa & Development \\
\hline Sheep Creek Campground & Bromus tectorum & Ash Mountain Developed Area & Vinca major & Development \\
\hline Sugarbowl Trail & Bromus tectorum & Ash Mountain Park Boundary & Catalpa bignonioides & Development \\
\hline Wuksachi & Bromus tectorum & Ash Mountain Park Boundary & Eucalyptus citriodora & Development \\
\hline Zumwalt Meadow Trail & Bromus tectorum & Ash Mountain Park Boundary & Melilotus indica & Development \\
\hline Ash Mountain Developed Area & Carduus pycnocephalus & Ash Mountain Park Boundary & Phalaris paradoxa & Development \\
\hline Colony Mill Road & Carduus pycnocephalus & Ash Mountain Slash Pit & Polypogon monspeliensis & Development \\
\hline Elk Creek Trail, M. F. Kaweah & Carduus pycnocephalus & Ash Mountain Slash Pit & Urtica urens & Development \\
\hline Hospital Rock & Carduus pycnocephalus & Atwell Mill Campground & Poa pratensis & Campground \\
\hline North Fork Parking Lot & Carduus pycnocephalus & Atwell Mill Campground & Trifolium repens & Campground \\
\hline Potwisha Campground & Carduus pycnocephalus & Austin Meadow & Poa pratensis & Pasture \\
\hline South Fork Campground & Carduus pycnocephalus & Azalea Campground & Bromus tectorum & Campground \\
\hline Sycamore Creek, M. F. Kaweah & Carduus pycnocephalus & Azalea Campground & Cirsium vulgare & Campground \\
\hline Yucca Creek, N. F. Kaweah & Carduus pycnocephalus & Azalea Campground & Holcus lanatus & Campground \\
\hline Grunnigan Ranch & Carya & Azalea Campground & Phalaris arundinacea & Campground \\
\hline Ash Mountain Park Boundary & Catalpa bignonioides & Azalea Campground & Poa bulbosa & Campground \\
\hline Generals Highway & Centaurea solstitialis & Azalea Campground & Poa pratensis & Campground \\
\hline Swale Campground & Centaurea solstitialis & Azalea Campground & Verbascum thapsus & Campground \\
\hline Sunset Campground & Cirsium vulgare & Azalea Campground & Verbascum virgatum & Campground \\
\hline Azalea Campground & Cirsium vulgare & Big Stump Picnic Area & Bromus tectonum & Development \\
\hline Cedar Grove Road & Cirsium vulgare & Big Stump Picnic Area & Poa pratensis & Development \\
\hline Columbine Picnic Area & Cirsium vulgare & Big Stump Picnic Area & Tragopogon dubius & Development \\
\hline Crystal Springs Campground & Cirsium vulgare & Buckeye Campground & Bromus tectorum & Campground \\
\hline Dorst Campground & Cirsium vulgare & Buckeye Campground & Marrubium vulgare & Campground \\
\hline Ferguson Creek Area & Cirsium vulgare & Buckeye Campground & Poa bulbosa & Campground \\
\hline Giant Forest Sewage Plant & Cirsium vulgare & Cahoon Meadow & Poa pratensis & Natural \\
\hline Grant Grove Developed Area & Cirsium vulgare & Camp Conifer & Bromus tectorum & Road \\
\hline Lodgepole Developed Area & Cirsium vulgare & Camp Conifer & Poa compressa & Road \\
\hline Marvin Pass Trail & Cirsium vilgare & Camp Conifer & Verbascum thapsus & Road \\
\hline Milk Ranch Road & Cirsium vulgare & Cedar Grove Market and Lodge & Bromus tectornim & Development \\
\hline Muir Grove & Cirsium vulgare & Cedar Grove Market and Lodge & Melilotus alba & Development \\
\hline Old Hidden Springs Road & Cirsium vulgare & Cedar Grove Market and Lodge & Poa bulbosa & Development \\
\hline Rae Lakes Loop Trail & Cirsium vulgare & Cedar Grove Market and Lodge & Poa pratensis & Development \\
\hline Red Fir Maintenance Area & Cirsium vulgare & Cedar Grove Pack Station & Bromus tectorum & Corral \\
\hline Redwood Canyon Trail & Cirsium vulgare & Cedar Grove Pack Station & Phalaris minor & Corral \\
\hline
\end{tabular}


Appendix A: (continued)

\begin{tabular}{|c|c|}
\hline Site & Alien Species \\
\hline Sequoia Lake Trail & Cirsium vulgare \\
\hline South Fork Campground & Cirsium vulgare \\
\hline Sugarbowl Trail & Cirsium vilgare \\
\hline Swale Campground & Cirsium vulgare \\
\hline Wuksachi & Cirsium vulgare \\
\hline Zumwalt Meadow Trail & Cirsium vulgare \\
\hline Ash Mountain Developed Area & Cistus \\
\hline Potwisha Campground & Convolvulus arvensis \\
\hline Sunset Campground & Dactulis glomerata \\
\hline Ash Mountain Developed Area & Dactylis glomerata \\
\hline Columbine Picnic Area & Dactylis glomerata \\
\hline Dorst Campground & Dactylis glomerata \\
\hline Generals Highway & Dactylis glomerata \\
\hline Giant Forest Developed Area & Dactylis glomerata \\
\hline Lodgepole Developed Area & Dactylis glomerata \\
\hline Trail For All People & Dactylis glomerata \\
\hline Cold Springs Campground & Digitalis purpurea \\
\hline Giant Forest Developed Area & Digitalis purpurea \\
\hline Grant Grove Developed Area & Digitalis purpurea \\
\hline Lodgepole Developed Area & Digitalis purpurea \\
\hline Sunset Campground & Digitalis purpurea \\
\hline Grunnigan Ranch & Diospyros \\
\hline Crystal Cave Road. & Echinochloa crus-galli \\
\hline Middle Fork, Kaweah River & Echinochloa crus-galli \\
\hline North Fork, Kaweah River & Echinochloa crus-galli \\
\hline Rae Lakes Loop Trail & Echinochloa crus-galli \\
\hline Sycamore Creek, M. F. Kaweah & Echinochloa crus-galli \\
\hline Wuksachi & Echinochloa crus-galli \\
\hline Ash Mountain Park Boundary & Eucalyptus citriodora \\
\hline Ash Mountain Developed Area & Festuca arundinacea \\
\hline Cedar Grove Road & Festuca arundinacea \\
\hline Dorst Campground & Festuca arundinacea \\
\hline Ash Mountain Developed Area & Festuca pratensis \\
\hline Crescent Meadow Trail & Festuca pratensis \\
\hline Middle Fork, Kaweah River & Ficus carica \\
\hline Yucca Creek, N. F. Kaweah & Ficus carica \\
\hline Ash Mountain Developed Area & Genista monspessulana \\
\hline Ash Mountain Developed Area & Hedera helix \\
\hline Ash Mountain Developed Area & Heteromeles arbutifolia \\
\hline Azalea Campground & Holcus lanatus \\
\hline Cedar Grove Road & Holcus lanatus \\
\hline Grant Grove Developed Area & Holcus lanatus \\
\hline Marvin Pass Trail & Holcus lanatus \\
\hline Lodgepole Developed Area & Iris \\
\hline Yucca Creek, N. F. Kaweah & Juglans californica \\
\hline Yucca Creek, N. F. Kaweah & Juglans regia \\
\hline Ash Mountain Developed Area & Lathyrus latifolius \\
\hline Traugers Creek, E. F. Kaweah & Lathyrus latifolius \\
\hline Ash Mountain Developed Area & Leucojum aestivum \\
\hline Ash Mountain Developed Area & Ligustrum sinense \\
\hline Cedar Grove Road & Lolium perenne \\
\hline Hospital Rock & Lolium perenne \\
\hline Traugers Creek, E. F. Kaweah & Malus sylvestris \\
\hline Buckeye Campground & Marrubium vulgare \\
\hline Potwisha Campground & Marrubium vulgare \\
\hline Sycamore Creek, M. F. Kaweah & Marrubium vulgare \\
\hline Ash Mountain Developed Area & Medicago sativa \\
\hline Milk Ranch Road & Medicago sativa \\
\hline Cedar Grove Market and Lodge & Melilotus alba \\
\hline Dorst Campground & Melilotus alba \\
\hline
\end{tabular}

\begin{tabular}{|c|c|c|}
\hline Site & Alien Species & Site Type \\
\hline Cedar Grove Pack Station & Poa bulbosa & Corral \\
\hline Cedar Grove Pack Station & Polypogon australis & Corral \\
\hline Cedar Grove Pack Station & Polypogon monspeliensis & Corral \\
\hline Cedar Grove Pack Station & Trifolium repens & Corral \\
\hline Cedar Grove Pack Station & Urtica urens & Corral \\
\hline Cedar Grove Road & Bromus tectorum & Road \\
\hline Cedar Grove Road & Cirsium vulgare & Road \\
\hline Cedar Grove Road & Festuca arundinacea & Road \\
\hline Cedar Grove Road & Holcus lanatus & Road \\
\hline Cedar Grove Road & Lolium perenne & Road \\
\hline Cedar Grove Road & Poa bulbosa & Road \\
\hline Cedar Grove Road & Poa pratensis & Road \\
\hline Cedar Grove Road & Tragopogon dubius & Road \\
\hline Cedar Grove Road & Verbascum thapsus & Road \\
\hline Cherry Flat Trail & Poa bulbosa & Trail \\
\hline Cold Springs Campground & Digitalis purpurea & Campground \\
\hline Cold Springs Campground & Poa pratensis & Campground \\
\hline Cold Springs Campground & Verbascum thapsus & Campground \\
\hline Colony Mill Road & Bromus tectorum & Road \\
\hline Colony Mill Road & Carduus pycnocephalus & Road \\
\hline Colony Mill Road & Morus alba & Riparian \\
\hline Columbine Picnic Area & Cirsium vulgare & Development \\
\hline Columbine Picnic Area & Dactylis glomerata & Riparian \\
\hline Columbine Picnic Area & Phalaris arundinacea & Development \\
\hline Columbine Picnic Area & Poa pratensis & Development \\
\hline Columbine Picnic Area & Trifolium repens & Development \\
\hline Crescent Meadow Trail & Festuca pratensis & Natural \\
\hline Crescent Meadow Trail & Phleum pratense & Natural \\
\hline Crescent Meadow Trail & Poa pratensis & Natural \\
\hline Crystal Cave Parking Lot & Bromus tectorum & Development \\
\hline Crystal Cave Parking Lot & Prunus persica & Development \\
\hline Crystal Cave Parking Lot & Tragopogon dubius & Development \\
\hline Crystal Cave Parking Lot & Vulpia bromoides & Development \\
\hline Crystal Cave Road. & Echinochloa crus-galli & Road \\
\hline Crystal Springs Campground & Cirsium vulgare & Campground \\
\hline Crystal Springs Campground & Poa pratensis & Campground \\
\hline Deadman Canyon Trail & Poa pratensis & Riparian \\
\hline Dorst Campground & Cirsium vulgare & Campground \\
\hline Dorst Campground & Dactylis glomerata & Campground \\
\hline Dorst Campground & Festuca arundinacea & Campground \\
\hline Dorst Campground & Melilotus alba & Campground \\
\hline Dorst Campground & Melilotus officinalis & Campground \\
\hline Dorst Campground & Poa pratensis & Campground \\
\hline Dorst Campground & Tragopogon dubius & Campground \\
\hline Dorst Campground & Trifolium repens & Campground \\
\hline Dorst Campground & Verbascum thapsus & Campground \\
\hline Elk Creek Trail, M. F. Kaweah & Carduus pycnocephalus & Natural \\
\hline Ferguson Creek Area & Cirsium vulgare & Natural \\
\hline Generals Highway & Centaurea solstitialis & Road \\
\hline Generals Highway & Dactylis glomerata & Road \\
\hline Generals Highway & Melilotus indica & Road \\
\hline Generals Highway & Oxalis pes-caprae & Road \\
\hline Generals Highway & Phalaris paradoxa & Road \\
\hline Generals Highway & Sorghum halepense & Road \\
\hline Generals Highway & Spartium junceum & Road \\
\hline Generals Highway & Tragopogon dubius & Road \\
\hline Generals Highway & Vicia sativa & Road \\
\hline Generals Highway & Vicia villosa & Road \\
\hline Generals Highway & Vinca major & Riparian \\
\hline Giant Forest Developed A & Dactylis glomerata & Development \\
\hline
\end{tabular}


Appendix A: (continued)

\begin{tabular}{|c|c|}
\hline Site & Alien Species \\
\hline Wuksachi & Melilotus alba \\
\hline Ash Mountain Developed Area & Melilotus indica \\
\hline Ash Mountain Park Boundary & Melilotus indica \\
\hline Generals Highway & Melilotus indica \\
\hline Sycamore Creek, M. F. Kaweah & Melilotus indica \\
\hline Dorst Campground & Melilotus officinalis \\
\hline North Fork, Kaweah River & Mentha pulegium \\
\hline North Fork, Kaweah River & Mentha spicata \\
\hline Colony Mill Road & Morus alba \\
\hline Middle Fork, Kaweah River & Morus alba \\
\hline Grunnigan Ranch & Nerium oleander \\
\hline Grunnigan Ranch & Olea europaea \\
\hline Ash Mountain Developed Area & Oxalis pes-caprae \\
\hline Generals Highway & Oxalis pes-caprae \\
\hline Azalea Campground & Phalaris arundinacea \\
\hline Columbine Picnic Area & Phalaris arundinacea \\
\hline Grant Grove Developed Area & Phalaris arundinacea \\
\hline Grant Grove Pack Station & Phalaris arundinacea \\
\hline Lodgepole Developed Area & Phalaris arundinacea \\
\hline Cedar Grove Pack Station & Phalaris minor \\
\hline Ash Mountain Park Boundary & Phalaris paradoxa \\
\hline Generals Highway & Phalaris paradoxa \\
\hline Crescent Meadow Trail & Phleum pratense \\
\hline Grant Grove Developed Area & Phleum pratense \\
\hline Hockett Meadow and Pasture & Phleum pratense \\
\hline Scaffold Meadow & Phleum pratense \\
\hline Trail For All People & Phleum pratense \\
\hline North Fork, Kaweah River & Piptatherum miliaceum \\
\hline Ash Mountain Developed Area & Poa bulbosa \\
\hline Azalea Campground & Poa bulbosa \\
\hline Buckeye Campground & Poa bulbosa \\
\hline Cedar Grove Market and Lodge & Poa bulbosa \\
\hline Cedar Grove Pack Station & Poa bulbosa \\
\hline Cedar Grove Road & Poa bulbosa \\
\hline Cherry Flat Trail & Poa bulbosa \\
\hline Giant Forest Developed Area & Poa bulbosa \\
\hline Lodgepole Campground & Poa bulbosa \\
\hline Milk Ranch Lookout & Poa bulbosa \\
\hline Potwisha Campground & Poa bulbosa \\
\hline Sheep Creek Campground & Poa bulbosa \\
\hline Camp Conifer & Poa compressa \\
\hline Sheep Creek Campground & Poa compressa \\
\hline Sunset Campground & Poa pratensis \\
\hline Ash Mountain Developed Area & Poa pratensis \\
\hline Atwell Mill Campground & Poa pratensis \\
\hline Austin Meadow & Poa pratensis \\
\hline Azalea Campground & Poa pratensis \\
\hline Big Stump Picnic Area & Poa pratensis \\
\hline Cahoon Meadow & Poa pratensis \\
\hline Cedar Grove Market and Lodge & Poa pratensis \\
\hline Cedar Grove Road & Poa pratensis \\
\hline Cold Springs Campground & Poa pratensis \\
\hline Columbine Picnic Area & Poa pratensis \\
\hline Crescent Meadow Trail & Poa pratensis \\
\hline Crystal Springs Campground & Poa pratensis \\
\hline Deadman Canyon Trail & Poa pratensis \\
\hline Dorst Campground & Poa pratensis \\
\hline Giant Forest Developed Area & Poapratensis \\
\hline Grant Grove Developed Area & Poa pratensis \\
\hline Grasshopper Meadow & Poa pratensis \\
\hline
\end{tabular}

\begin{tabular}{|c|c|c|}
\hline Site & Alien Species & Site Type \\
\hline Giant Forest Developed Area & Digitalis purpurea & Development \\
\hline Giant Forest Developed Area & Poa bulbosa & Development \\
\hline Giant Forest Developed Area & Poa pratensis & Development \\
\hline Giant Forest Developed Area & Tragopogon dubius & Development \\
\hline Giant Forest Developed Area & Verbascum thapsus & Development \\
\hline Giant Forest Sewage Plant & Bromus tectorum & Development \\
\hline Giant Forest Sewage Plant & Cirsium vulgare & Development \\
\hline Giant Forest Sewage Plant & Rubus & Development \\
\hline Grant Grove Developed Area & Cirsium vulgare & Development \\
\hline Grant Grove Developed Area & Digitalis purpurea & Development \\
\hline Grant Grove Developed Area & Holcus lanatus & Development \\
\hline Grant Grove Developed Area & Phalaris arundinacea & Development \\
\hline Grant Grove Developed Area & Phleum pratense & Development \\
\hline Grant Grove Developed Area & Poa pratensis & Development \\
\hline Grant Grove Developed Area & Tanacetum parthenium & Development \\
\hline Grant Grove Developed Area & Trifolium repens & Development \\
\hline Grant Grove Developed Area & Verbascum thapsus & Development \\
\hline Grant Grove Pack Station & Phalaris arundinacea & Corral \\
\hline Grant Grove Pack Station & Urtica urens & Corral \\
\hline Grasshopper Meadow & Poa pratensis & Pasture \\
\hline Grunnigan Ranch & Carya & Development \\
\hline Grunnigan Ranch & Diospyros & Development \\
\hline Grunnigan Ranch & Nerium oleander & Development \\
\hline Grunnigan Ranch & Olea europaea & Development \\
\hline Grunnigan Ranch & Punica granatum & Development \\
\hline Grunnigan Ranch & Pyracantha angustifolia & Development \\
\hline Grunnigan Ranch & Rubus discolor & Development \\
\hline Halstead Meadow & Poa pratensis & Natural \\
\hline Halstead Meadow & Tragopogon dubius & Natural \\
\hline High Sierra Trail & Bromus tectorum & Trail \\
\hline High Sierra Trail & Poa pratensis & Trail \\
\hline Hockett Meadow and Pasture & Phleum pratense & Trail \\
\hline Hockett Meadow and Pasture & Poa pratensis & Pasture \\
\hline Hospital Rock & Carduus pycnocephalus & Development \\
\hline Hospital Rock & Lolium perenne & Development \\
\hline Hospital Rock & Poa pratensis & Development \\
\hline Hospital Rock & Polypogon monspeliensis & Road \\
\hline JR Meadow & Poa pratensis & Pasture \\
\hline Kern Ranger Station Pasture & Poa pratensis & Pasture \\
\hline Lewis Creek Trail & Bromus tectorum & Trail \\
\hline Lewis Creek Trail & Poa pratensis & Riparian \\
\hline Lodgepole Campground & Bromus tectorum & Campground \\
\hline Lodgepole Campground & Poa bulbosa & Campground \\
\hline Lodgepole Campground & Poa pratensis & Campground \\
\hline Lodgepole Developed Area & Cirsium vulgare & Development \\
\hline Lodgepole Developed Area & Dactylis glomerata & Development \\
\hline Lodgepole Developed Area & Digitalis purpurea & Development \\
\hline Lodgepole Developed Area & Iris & Development \\
\hline Lodgepole Developed Area & Phalaris arundinacea & Development \\
\hline Lodgepole Developed Area & Verbascum thapsus & Development \\
\hline Lodgepole Developed Area & Verbascum virgatum & Development \\
\hline Marble Fork, Kaweah River & Rubus discolor & Riparian \\
\hline Marvin Pass Trail & Cirsium vulgare & Trail \\
\hline Marvin Pass Trail & Holcus lanatus & Trail \\
\hline Marvin Pass Trail & Poapratensis & Trail \\
\hline Middle Fork Flume & Bromus tectorum & Development \\
\hline Middle Fork, Kaweah River & Echinochloa crus-galli & Riparian \\
\hline Middle Fork, Kaweah River & Ficus carica & Riparian \\
\hline Middle Fork, Kaweah River & Morus alba & Riparian \\
\hline Middle Fork, Kaweah River & Polypogon monspeliensis & Riparian \\
\hline
\end{tabular}


Appendix A: (continued)

\begin{tabular}{|c|c|}
\hline Site & Alien Species \\
\hline Halstead Meadow & Poa pratensis \\
\hline High Sierra Trail & Poa pratensis \\
\hline Hockett Meadow and Pasture & Poa pratensis \\
\hline Hospital Rock & Poa pratensis \\
\hline JR Meadow & Poa pratensis \\
\hline Kern Ranger Station Pasture & Poa pratensis \\
\hline Lewis Creek Trail & Poa pratensis \\
\hline Lodgepole Campground & Poa pratensis \\
\hline Marvin Pass Trail & Poa pratensis \\
\hline Mineral King Pack Station & Poa pratensis \\
\hline Oriole Lake Meadow & Poa pratensis \\
\hline Oriole Lake Road & Poa pratensis \\
\hline Potwisha Campground & Poa pratensis \\
\hline Rae Lakes Loop Trail & Poa pratensis \\
\hline Rae Lakes Loop Trail & Poa pratensis \\
\hline Rae Lakes Loop Trail & Poa pratensis \\
\hline Rae Lakes Loop Trail & Poa pratensis \\
\hline Rattlesnake Creek Trail & Poa pratensis \\
\hline Red Fir Maintenance Area & Poa pratensis \\
\hline Redwood Creek, Mineral King & Poa pratensis \\
\hline Scaffold Meadow & Poa pratensis \\
\hline Sequoia Lake Trail & Poa pratensis \\
\hline Sheep Creek Campground & Poa pratensis \\
\hline Sugarloaf Meadow & Poa pratensis \\
\hline Traugers Creek, E. F. Kaweah & Poa pratensis \\
\hline Williams Meadow & Poa pratensis \\
\hline Wolverton Snow Play Area & Poa pratensis \\
\hline Yucca Creek, N. F. Kaweah & Poa pratensis \\
\hline Zumwalt Meadow Trail & Poa pratensis \\
\hline Cedar Grove Pack Station & Polypogon australis \\
\hline Yucca Creek, N. F. Kaweah & Polypogon interruptus \\
\hline Ash Mountain Developed Area & Polypogon monspeliensis \\
\hline Ash Mountain Slash Pit & Polypogon monspeliensis \\
\hline Cedar Grove Pack Station & Polypogon monspeliensis \\
\hline Hospital Rock & Polypogon monspeliensis \\
\hline Middle Fork, Kaweah River & Polypogon monspeliensis \\
\hline North Fork, Kaweah River & Polypogon monspeliensis \\
\hline Shepherd Saddle Road & Polypogon monspeliensis \\
\hline Shepherd Saddle Road & Polypogon monspeliensis \\
\hline Sycamore Creek, M. F. Kaweah & Polypogon monspeliensis \\
\hline Yucca Creek, N. F. Kaweah & Polypogon monspeliensis \\
\hline Crystal Cave Parking Lot & Prunus persica \\
\hline Ash Mountain Developed Area & Punica granatum \\
\hline Grunnigan Ranch & Punica granatum \\
\hline Ash Mountain Developed Area & Pyracantha angustifolia \\
\hline Grunnigan Ranch & Pyracantha angustifolia \\
\hline Middle Fork, Kaweah River & Pyracantha angustifolia \\
\hline Sycamore Creek, M. F. Kaweah & Pyracantha angustifolia \\
\hline Potwisha Campground & Ranunculus parviflorus \\
\hline Sentinel Campground & Ramunculus testiculatus \\
\hline Giant Forest Sewage Plant & Rubus \\
\hline Grunnigan Ranch & Rubus discolor \\
\hline Marble Fork, Kaweah River & Rubus discolor \\
\hline North Fork, Kaweah River & Rubus discolor \\
\hline Potwisha Campground & Rubus discolor \\
\hline Redwood Creek, Mineral King & Rubus discolor \\
\hline Yucca Creek, N. F. Kaweah & Rubus discolor \\
\hline Old Hidden Springs Road & Silybum marianum \\
\hline Yucca Creek, N. F. Kaweah & Silybum marianum \\
\hline Generals Highway & Sorghum halepense \\
\hline
\end{tabular}

\begin{tabular}{|c|c|c|}
\hline Site & Alien Species & Site Type \\
\hline Middle Fork, Kaweah River & Pyracantha angustifolia & Riparian \\
\hline Middle Fork, Kaweah River & Spartium junceum & Riparian \\
\hline Middle Fork, Kaweah River & Tamarix & Riparian \\
\hline Milk Ranch Lookout & Bromus tectorum & Development \\
\hline Milk Ranch Lookout & Poa bulbosa & Development \\
\hline Milk Ranch Road & Cirsium vulgare & Road \\
\hline Milk Ranch Road & Medicago sativa & Road \\
\hline Mineral King Pack Station & Poa pratensis & Development \\
\hline Mineral King Pack Station & Trifolium repens & Development \\
\hline Mineral King Pack Station & Urtica urens & Corral \\
\hline Mineral King Pack Station & Verbascum thapsus & Road \\
\hline Moraine Campground & Bromus tectorum & Campground \\
\hline Muir Grove & Cirsium vulgare & Natural \\
\hline North Fork Parking Lot & Carduus pycnocephalus & Development \\
\hline North Fork, Kaweah River & Echinochloa crus-galli & Riparian \\
\hline North Fork, Kaweah River & Mentha pulegium & Riparian \\
\hline North Fork, Kaweah River & Mentha spicata & Riparian \\
\hline North Fork, Kaweah River & Piptatherum miliaceum & Riparian \\
\hline North Fork, Kaweah River & Polypogon monspeliensis & Riparian \\
\hline North Fork, Kaweah River & Rubus discolor & Riparian \\
\hline North Fork, Kaweah River & Tamarix & Riparian \\
\hline North Fork, Kaweah River & Verbascum thapsus & Riparian \\
\hline Old Hidden Springs Road & Cirsium vulgare & Riparian \\
\hline Old Hidden Springs Road & Silybum marianum & Trail \\
\hline Old Hidden Springs Road & Vicia benghalensis & Road \\
\hline Oriole Lake Airstrip & Vulpia bromoides & Development \\
\hline Oriole Lake Meadow & Bromus tectorum & Pasture \\
\hline Oriole Lake Meadow & Poa pratensis & Pasture \\
\hline Oriole Lake Meadow & Trifolium repens & Pasture \\
\hline Oriole Lake Meadow & Verbascum thapsus & Pasture \\
\hline Oriole Lake Road & Bromus tectorum & Road \\
\hline Oriole Lake Road & Poa pratensis & Road \\
\hline Oriole Lake Road & Trifolium repens & Road \\
\hline Oriole Lake Road & Verbascum thapsus & Road \\
\hline Potwisha Campground & Carduus pycnocephalus & Campground \\
\hline Potwisha Campground & Convolvulus arvensis & Campground \\
\hline Potwisha Campground & Marrubium vulgare & Campground \\
\hline Potwisha Campground & Poa bulbosa & Campground \\
\hline Potwisha Campground & Poa pratensis & Campground \\
\hline Potwisha Campground & Ranunculus parviflorus & Campground \\
\hline Potwisha Campground & Rubus discolor & Campground \\
\hline Potwisha Campground & Urtica urens & Campground \\
\hline Potwisha Campground & Vinca major & Campground \\
\hline Potwisha Campground & Vulpia bromoides & Dirt Road \\
\hline Rae Lakes Loop Trail & Bromus tectorum & Trail \\
\hline Rae Lakes Loop Trail & Cirsium vulgare & Trail \\
\hline Rae Lakes Loop Trail & Echinochloa crus-galli & Trail \\
\hline Rae Lakes Loop Trail & Poa pratensis & Natural \\
\hline Rae Lakes Loop Trail & Poapratensis & Pasture \\
\hline Rae Lakes Loop Trail & Poa pratensis & Riparian \\
\hline Rae Lakes Loop Trail & Poa pratensis & Trail \\
\hline Rae Lakes Loop Trail & Verbascum thapsus & Riparian \\
\hline Rattlesnake Creek Trail & Poa pratensis & Riparian \\
\hline Red Fir Maintenance Area & Bromus tectorum & Development \\
\hline Red Fir Maintenance Area & Cirsium vulgare & Development \\
\hline Red Fir Maintenance Area & Poa pratensis & Development \\
\hline Red Fir Maintenance Area & Verbascum virgatum & Development \\
\hline Redwood Canyon Trail & Cirsium vulgare & Trail \\
\hline Redwood Canyon Trail & Trifolium repens & Trail \\
\hline Redwood Creek, Mineral King & Bromus tectorum & Development \\
\hline
\end{tabular}


Appendix A: (continued)

\begin{tabular}{|c|c|}
\hline Site & Alien Species \\
\hline Ash Mountain Developed Area & Spartium junceum \\
\hline Generals Highway & Spartium junceum \\
\hline Middle Fork, Kaweah River & Spartium junceum \\
\hline Middle Fork, Kaweah River & Tamarix \\
\hline North Fork, Kaweah River & Tamarix \\
\hline Sycamore Creek, M. F. Kaweah & Tamarix \\
\hline Grant Grove Developed Area & Tanacetum parthenium \\
\hline Big Stump Picnic Area & Tragopogon dubius \\
\hline Cedar Grove Road & Tragopogon dubius \\
\hline Crystal Cave Parking Lot & Tragopogon dubius \\
\hline Dorst Campground & Tragopogon dubius \\
\hline Generals Highway & Tragopogon dubius \\
\hline Giant Forest Developed Area & Tragopogon dubius \\
\hline Halstead Meadow & Tragopogon dubius \\
\hline South Fork Campground & Tragopogon dubius \\
\hline Wolverton Pack Station & Tragopogon dubius \\
\hline Wuksachi & Tragopogon dubius \\
\hline Ash Mountain Developed Area & Trifolium repens \\
\hline Atwell Mill Campground & Trifolium repens \\
\hline Cedar Grove Pack Station & Trifolium repens \\
\hline Columbine Picnic Area & Trifolium repens \\
\hline Dorst Campground & Trifolium repens \\
\hline Grant Grove Developed Area & Trifolium repens \\
\hline Mineral King Pack Station & Trifolium repens \\
\hline Oriole Lake Meadow & Trifolium repens \\
\hline Oriole Lake Road & Trifolium repens \\
\hline Redwood Canyon Trail & Trifoïum repens \\
\hline Redwood Creek, Mineral King & Trifolium repens \\
\hline Ash Mountain Slash Pit & Urtica urens \\
\hline Cedar Grove Pack Station & Urtica urens \\
\hline Grant Grove Pack Station & Urtica urens \\
\hline Mineral King Pack Station & Urtica urens \\
\hline Potwisha Campground & Urtica urens \\
\hline Sunset Campground & Verbascum thapsus \\
\hline Ash Mountain Developed Area & Verbascum thapsus \\
\hline Azalea Campground & Verbascum thapsus \\
\hline Camp Conifer & Verbascum thapsus \\
\hline Cedar Grove Road & Verbascum thapsus \\
\hline Cold Springs Campground & Verbascum thapsus \\
\hline Dorst Campground & Verbascum thapsus \\
\hline Giant Forest Developed Area & Verbascum thapsus \\
\hline Grant Grove Developed Area & Verbascum thapsus \\
\hline Lodgepole Developed Area & Verbascum thapsus \\
\hline Mineral King Pack Station & Verbascum thapsus \\
\hline North Fork, Kaweah River & Verbascum thapsus \\
\hline Oriole Lake Meadow & Verbascum thapsus \\
\hline Oriole Lake Road & V'erbascum thapsus \\
\hline Rae Lakes Loop Trail & Verbascum thapsus \\
\hline Swale Campground & Verbascum thapsus \\
\hline Wuksachi & Verbascum thapsus \\
\hline Zumwalt Meadow Trail & Verbascum thapsus \\
\hline Azalea Campground & Verbascum virgatum \\
\hline Lodgepole Developed Area & Verbascum virgatum \\
\hline Red Fir Maintenance Area & Verbascum virgatum \\
\hline Wuksachi & Verbascum virgatum \\
\hline Old Hidden Springs Road & Vicia benghalensis \\
\hline Ash Mountain Developed Area & Vicia sativa \\
\hline Generals Highway & licia sativa \\
\hline Generals Highway & Vicia villosa \\
\hline Ash Mountain Developed Area & Vinca major \\
\hline
\end{tabular}

\begin{tabular}{|c|c|c|}
\hline Site & Alien Species & Site Type \\
\hline Redwood Creek, Mineral King & Poa pratensis & Development \\
\hline Redwood Creek, Mineral King & Rubus discolor & Development \\
\hline Redwood Creek, Mineral King & Trifolium repens & Development \\
\hline Scaffold Meadow & Phleum pratense & Pasture \\
\hline Scaffold Meadow & Poa pratensis & Pasture \\
\hline Sentinel Campground & Ranunculus testiculatus & Campground \\
\hline Sequoia Lake Trail & Cirsium vulgare & Trail \\
\hline Sequoia Lake Trail & Poa pratensis & Riparian \\
\hline Sheep Creek Campground & Bromus tectorum & Campground \\
\hline Sheep Creek Campground & Poa bulbosa & Campground \\
\hline Sheep Creek Campground & Poa compressa & Campground \\
\hline Sheep Creek Campground & Poa pratensis & Campground \\
\hline Shepherd Saddle Road & Polypogon monspeliensis & Development \\
\hline Shepherd Saddle Road & Polypogon monspeliensis & Road \\
\hline South Fork Campground & Carduus pycnocephalus & Campground \\
\hline South Fork Campground & Cirsium vulgare & Campground \\
\hline South Fork Campground & Tragopogon dubius & Campground \\
\hline South Fork Campground & Vulpia bromoides & Campground \\
\hline Sugarbowl Trail & Bromus tectorum & Natural \\
\hline Sugarbowl Trail & Cirsium vulgare & Natural \\
\hline Sugarloaf Meadow & Poa pratensis & Pasture \\
\hline Sunset Campground & Bromus tectorum & Natural \\
\hline Sunset Campground & Cirsium vulgare & Natural \\
\hline Sunset Campground & Dactylis glomerata & Natural \\
\hline Sunset Campground & Digitalis purpurea & Natural \\
\hline Sunset Campground & Poa pratensis & Natural \\
\hline Sunset Campground & Verbascum thapsus & Natural \\
\hline Swale Campground & Centaurea solstitialis & Campground \\
\hline Swale Campground & Cirsium vulgare & Campground \\
\hline Swale Campground & Verbascum thapsus & Campground \\
\hline Sycamore Creek, M. F. Kaweah & Arundo donax & Riparian \\
\hline Sycamore Creek, M. F. Kaweah & Carduus pycnocephalus & Riparian \\
\hline Sycamore Creek, M. F. Kaweah & Echinochloa crus-galli & Riparian \\
\hline Sycamore Creek, M. F. Kaweah & Marrubium vulgare & Riparian \\
\hline Sycamore Creek, M. F. Kaweah & Melilotus indica & Riparian \\
\hline Sycamore Creek, M. F. Kaweah & Polypogon monspeliensis & Riparian \\
\hline Sycamore Creek, M. F. Kaweah & Pyracantha angustifolia & Riparian \\
\hline Sycamore Creek, M. F. Kaweah & Tamarix & Riparian \\
\hline Trail For All People & Dactylis glomerata & Trail \\
\hline Trail For All People & Phleum pratense & Trail \\
\hline Traugers Creek, E. F. Kaweah & Lathyrus latifolius & Riparian \\
\hline Traugers Creek, E. F. Kaweah & Malus sylvestris & Riparian \\
\hline Traugers Creek, E. F. Kaweah & Poa pratensis & Riparian \\
\hline Williams Meadow & Poa pratensis & Pasture \\
\hline Wolverton Pack Station & Tragopogon dubius & Pack Station \\
\hline Wolverton Snow Play Area & Poa pratensis & Development \\
\hline Wuksachi & Bromus tectorum & Development \\
\hline Wuksachi & Cirsium vulgare & Development \\
\hline Wuksachi & Echinochloa cris-galli & Development \\
\hline Wuksachi & Melilotus alba & Development \\
\hline Wuksachi & Tragopogon dubius & Development \\
\hline Wuksachi & Verbascum thapsus & Development \\
\hline Wuksachi & Verbascum virgatum & Development \\
\hline Yucca Creek, N. F. Kaweah & Carduus pycnocephalus & Riparian \\
\hline Yucca Creek, N. F. Kaweah & Ficus curica & Riparian \\
\hline Yucca Creek, N. F. Kaweah & Juglans californica & Riparian \\
\hline Yucca Creek, N. F. Kaweah & Juglans regia & Riparian \\
\hline Yucca Creek, N. F. Kaweah & Poa pratensis & Riparian \\
\hline Yucca Creek, N. F. Kaweah & Polypogon internuptus & Riparian \\
\hline Yucca Creek, N. F. Kaweah & Polypogon monspeliensis & Riparian \\
\hline
\end{tabular}


Appendix A: (continued)

\begin{tabular}{|l|l|}
\hline \multicolumn{1}{|c|}{ Site } & \multicolumn{1}{c|}{ Alien Species } \\
\hline Generals Highway & Vinca major \\
Potwisha Campground & Vinca major \\
Yucca Creek, N. F. Kaweah & Vitis vinifera \\
Crystal Cave Parking Lot & Vulpia bromoides \\
Oriole Lake Airstrip & Vulpia bromoides \\
Potwisha Campground & Vulpia bromoides \\
South Fork Campground & Vulpia bromoides \\
\hline
\end{tabular}

\begin{tabular}{|lll|}
\hline \multicolumn{1}{|c|}{ Site } & \multicolumn{1}{c|}{ Alien Species } & \multicolumn{1}{c|}{ Site Type } \\
\hline Yucca Creek, N. F. Kaweah & Rubus discolor & Riparian \\
Yucca Creek, N. F. Kaweah & Silybum marianum & Riparian \\
Yucca Creek, N. F. Kaweah & Vitis vinifera & Riparian \\
Zumwalt Meadow Trail & Bromus tectorum & Riparian \\
Zumwalt Meadow Trail & Cirsium vulgare & Riparian \\
Zumwalt Meadow Trail & Poa pratensis & Riparian \\
Zumwalt Meadow Trail & Verbascum thapsus & Riparian \\
\hline
\end{tabular}


Appendix B. Yosemite National Park - priority alien species by species and by site.

\begin{tabular}{|c|c|c|c|c|}
\hline Site & Alien Species & Site & Alien Species & Site Type \\
\hline Backpacker's Camp & Agrostis gigantea & Alder Creek Trail & Bromus tectorum & Trail \\
\hline Concession Stables (YV) & Agrostis gigantea & Alder Creek Trail & Holcus lanatus & Trail \\
\hline Foresta East & Agrostis gigantea & Alder Creek Trail & Hypericum perforatum & Trail \\
\hline Foresta West & Agrostis gigantea & Alder Creek Trail & Poa pratensis & Trail \\
\hline Happy Isles & Agrostis gigantea & Backpacker's Camp & Agrostis gigantea & Campground \\
\hline Housekeeping Camp & Agrostis gigantea & Backpacker's Camp & Bromus tectorum & Campground \\
\hline Lower Pines Campground & Agrostis gigantea & Backpacker's Camp & Cirsium vulgare & Campground \\
\hline Lower River Campground & Agrostis gigantea & Backpacker's Camp & Holcus lanatus & Campground \\
\hline Meadow Loop Trail - Wawona & Agrostis gigantea & Backpacker's Camp & Poa pratensis & Campground \\
\hline Mirror Lake & Agrostis gigantea & Backpacker's Camp & Rubus discolor & Campground \\
\hline North Pines Campground & Agrostis gigantea & Backpacker's Camp & Verbascum thapsus & Campground \\
\hline North Wawona-Central section & Agrostis gigantea & Badger Pass Parking Area & Cirsium vulgare & Development \\
\hline North Wawona-Western section & Agrostis gigantea & Badger Pass Parking Area & Poa pratensis & Development \\
\hline Old Big Oak Flat Rd. Trail & Agrostis gigantea & Badger Pass Parking Area & Verbascum thapsus & Development \\
\hline Snow Creek Trail & Agrostis gigantea & Badger Pass Ski Resort & Poa pratensis & Development \\
\hline The Ahwahnee hotel & Agrostis gigantea & Big Oak Flat Road (4661) & Bromus tectorum & Road \\
\hline Upper Old El Portal & Agrostis gigantea & Big Oak Flat Road (4661) & Holcus lanatus & Road \\
\hline Wawona Road (6051) & Agrostis gigantea & Big Oak Flat Road (4661) & Hypericum perforatum & Road \\
\hline Wawona Road 3 (6040) & Agrostis gigantea & Big Oak Flat Road (4661) & Phleum pratense & Road \\
\hline Yosemite Lodge & Agrostis gigantea & Big Oak Flat Road (4661) & Poa bulbosa & Road \\
\hline Yosemite Loop Trail & Agrostis gigantea & Big Oak Flat Road (4946) & Bromus tectorum & Road \\
\hline Yosemite Village & Agrostis gigantea & Big Oak Flat Road (4946) & Dactylis glomerata & Road \\
\hline Concession Stables (YV) & Bromus inermis & Big Oak Flat Road (4946) & Hypericum perforatum & Road \\
\hline Curry Village & Bromus inermis & Big Oak Flat Road (4946) & Lathyrus latifolius & Road \\
\hline El Portal Road & Bromus inermis & Big Oak Flat Road (4946) & Phleum pratense & Road \\
\hline Foresta East & Bromus inermis & Big Oak Flat Road (4946) & Poa bulbosa & Road \\
\hline Happy Isles & Bromus inermis & Big Oak Flat Road (5272) & Bromus tectorum & Road \\
\hline Hetch Hetchy Road (5505) & Bromus inermis & Big Oak Flat Road (5272) & Holcus lanatus & Road \\
\hline Housekeeping Camp & Bromus inermis & Big Oak Flat Road (5272) & Poa pratensis & Road \\
\hline Lower Old El Portal & Bromus inermis & Big Oak Flat Road (5902) & Bromus tectorum & Road \\
\hline Lower River Campground & Bromus inermis & Big Oak Flat Road (5902) & Cirsium vulgare & Road \\
\hline McCauley Ranch & Bromus inermis & Bridalveil Campground & Holcus lanatus & Campground \\
\hline Meadow Loop Trail - Wawona & Bromus inermis & Bridalveil Campground & Poa pratensis & Campground \\
\hline North Pines Campground & Bromus inermis & Bridalveil Creek Trail & Poa pratensis & Trail \\
\hline North Wawona-Central section & Bromus inermis & Bridalveil Falls - Inspiration Point & Bromus tectorum & Trail \\
\hline North Wawona-Western section & Bromus inermis & Bridalveil Falls - Inspiration Point & Cirsium vulgare & Trail \\
\hline Panorama Trail & Bromus inermis & Bridalveil Falls - Inspiration Point & Holcus lanatus & Trail \\
\hline The Ahwahnee hotel & Bromus inermis & Bridalveil Falls Trail & Bromus tectorum & Trail \\
\hline Tioga Road (7981) & Bromus inermis & Bridalveil Falls Trail & Poa bulbosa & Trail \\
\hline Tuolumne Grove & Bromus inermis & Bridalveil Falls Trail & Poa pratensis & Trail \\
\hline Upper Old El Portal & Bromus inermis & Chilnualna Falls Trail & Bromus tectorum & Trail \\
\hline Upper Rancheria - El Portal & Bromus inermis & Chilnualna Falls Trail & Holcus lanatus & Trail \\
\hline Wawona Road 2 (5143) & Bromus inermis & Chilnualna Falls Trail & Poa compressa & Trail \\
\hline Wawona Road 3 (6040) & Bromus inermis & Concession Stables (YV) & Agrostis gigantea & Stock \\
\hline Yosemite Lodge & Bromus inermis & Concession Stables (YV) & Bromus inermis & Stock \\
\hline Yosemite Village & Bromus inermis & Concession Stables (YV) & Bromus tectorum & Stock \\
\hline Alder Creek Trail & Bromus tectorum & Concession Stables (YV) & Cirsium vulgare & Stock \\
\hline Backpacker's Camp & Bromus tectorum & Concession Stables (YV) & Dactylis glomerata & Stock \\
\hline Big Oak Flat Road (4661) & Bromus tectorum & Concession Stables (YV) & Holcus lanatus & Stock \\
\hline
\end{tabular}


Appendix B. (continued)

\begin{tabular}{|c|c|}
\hline $\overrightarrow{\text { Site }}$ & Alien Species \\
\hline Big Oak Flat Road (4946) & Bromus tectorum \\
\hline Big Oak Flat Road (5272) & Bromus tectorum \\
\hline Big Oak Flat Road (5902) & Bromus tectorum \\
\hline Bridalveil Falls - Inspiration Point & Bromus tectorum \\
\hline Bridalveil Falls Trail & Bromus tectorum \\
\hline Chilnualna Falls Trail & Bromus tectorum \\
\hline Concession Stables (YV) & Bromus tectorum \\
\hline El Portal Road & Bromus tectorum \\
\hline Foresta East & Bromus tectorum \\
\hline Foresta West & Bromus tectorum \\
\hline Four-mile Trail & Bromus tectorum \\
\hline Government Stables & Bromus tectorum \\
\hline Happy Isles & Bromus tectorum \\
\hline Hetch Hetchy Backpacker's Camp & Bromus tectorum \\
\hline Hetch Hetchy Corral & Bromus tectorum \\
\hline Hetch Hetchy Road (5505) & Bromus tectorum \\
\hline Inspiration Pt. Trail & Bromus tectorum \\
\hline Lower Old El Portal & Bromus tectorum \\
\hline Lower Pines Campground & Bromus tectorum \\
\hline Lower River Campground & Bromus tectorum \\
\hline Mariposa Grove Trail & Bromus tectorum \\
\hline McCauley Ranch & Bromus tectorum \\
\hline Meadow Loop Trail - Wawona & Bromus tectorum \\
\hline Mirror Lake & Bromus tectorum \\
\hline Mirror Lake Pack Trail & Bromus tectorum \\
\hline North Pines Campground & Bromus tectorum \\
\hline North Wawona-Central section & Bromus tectorum \\
\hline North Wawona-Eastern section & Bromus tectorum \\
\hline North Wawona-Western section & Bromus tectorum \\
\hline Northside Drive & Bromus tectorum \\
\hline Old Big Oak Flat Rd. Trail & Bromus tectorum \\
\hline Panorama Trail & Bromus tectorum \\
\hline Snow Creek Trail & Bromus tectorum \\
\hline Southside Drive & Bromus tectorum \\
\hline Sunnyside Campground & Bromus tectorum \\
\hline The Ahwahnee hotel & Bromus tectorum \\
\hline Tioga Road (8472) & Bromus tectorum \\
\hline Upper Pines Campground & Bromus tectorum \\
\hline Upper Rancheria - El Portal & Bromus tectorum \\
\hline Wawona Campground & Bromus tectorum \\
\hline Wawona Road (3964) & Bromus tectomim \\
\hline Wawona Road (6051) & Bromus tectorum \\
\hline Wawona Road 2 (5143) & Bromus tectorum \\
\hline Wawona Road 3 (6040) & Bromus tectorum \\
\hline Wawona Stables & Bromus tectorum \\
\hline Yosemite Falls Trail & Bromus tectorum \\
\hline Yosemite Lodge & Bromus tectorum \\
\hline Yosemite Loop Trail & Bromus tectorum \\
\hline Yosemite Village & Bromus tectomm \\
\hline Yosemite West & Bromus tectorum \\
\hline Lower River Campground & Carduus pycnocephalus \\
\hline
\end{tabular}

\begin{tabular}{|c|c|c|}
\hline Site & Alien Species & Site Type \\
\hline Concession Stables (YV) & Hypericum perforatum & Stock \\
\hline Concession Stables (YV) & Leucanthemum vulgare & Stock \\
\hline Concession Stables (YV) & Lolium perenne & Stock \\
\hline Concession Stables (YV) & Phleum pratense & Stock \\
\hline Concession Stables (YV) & Poa bulbosa & Stock \\
\hline Concession Stables (YV) & Poa pratensis & Stock \\
\hline Concession Stables (YV) & Rubus discolor & Stock \\
\hline Concession Stables (YV) & Tragopogon dubius & Stock \\
\hline Concession Stables (YV) & Trifolium repens & Stock \\
\hline Concession Stables (YV) & Verbascum thapsus & Stock \\
\hline Crane Flat Campground & Cirsium vulgare & Campground \\
\hline Crane Flat Campground & Phleum pratense & Campground \\
\hline Curry Village & Bromus inermis & Development \\
\hline Curry Village & Cirsium vulgare & Development \\
\hline Curry Village & Dactylis glomerata & Development \\
\hline Curry Village & Holcus lanatus & Development \\
\hline Curry Village & Lolium perenne & Development \\
\hline Curry Village & Phleum pratense & Development \\
\hline Curry Village & Poa pratensis & Development \\
\hline Curry Village & Rubus discolor & Development \\
\hline Curry Village & Trifolium repens & Development \\
\hline El Portal Road & Bromus inermis & Road \\
\hline El Portal Road & Bromus tectorum & Road \\
\hline El Portal Road & Poa bulbosa & Road \\
\hline El Portal Road & Poa pratensis & Road \\
\hline Foresta East & Agrostis gigantea & Development \\
\hline Foresta East & Bromus inermis & Development \\
\hline Foresta East & Bromus tectorum & Development \\
\hline Foresta East & Centaurea maculosa & Development \\
\hline Foresta East & Centaurea solstitialis & Development \\
\hline Foresta East & Cirsium vulgare & Development \\
\hline Foresta East & Digitalis purpurea & Development \\
\hline Foresta East & Holcus lanatus & Development \\
\hline Foresta East & Lathyrus latifolius & Development \\
\hline Foresta East & Leucanthemum vulgare & Development \\
\hline Foresta East & Poa pratensis & Development \\
\hline Foresta East & Tragopogon dubius & Development \\
\hline Foresta East & Trifolium repens & Development \\
\hline Foresta West & Agrostis gigantea & Development \\
\hline Foresta West & Bromus tectorum & Development \\
\hline Foresta West & Cirsium vulgare & Development \\
\hline Foresta West & Holcus lanatus & Development \\
\hline Foresta West & Leucanthemum vulgare & Development \\
\hline Foresta West & Lolium perenne & Development \\
\hline Foresta West & Poa pratensis & Development \\
\hline Foresta West & Tragopogon dubius & Development \\
\hline Foresta West & Verbascum thapsus & Development \\
\hline Four-mile Trail & Bromus tectorum & Trail \\
\hline Four-mile Trail & Holcus lanatus & Trail \\
\hline Four-mile Trail & Poa bulbosa & Trail \\
\hline Four-mile Trail & Poa pratensis & Trail \\
\hline
\end{tabular}


Appendix B. (continued)

\begin{tabular}{|c|c|}
\hline Site & Alien Species \\
\hline Foresta East & Centaurea maculosa \\
\hline Foresta East & Centaurea solstitialis \\
\hline Hetch Hetchy Corral & Centaurea solstitialis \\
\hline Lower Old El Portal & Centaurea solstitialis \\
\hline McCauley Ranch & Centaurea solstitialis \\
\hline Upper Old El Portal & Centaurea solstitialis \\
\hline Upper Rancheria - El Portal & Centaurea solstitialis \\
\hline Wawona Road 2 (5143) & Centaurea solstitialis \\
\hline Backpacker's Camp & Cirsium vulgare \\
\hline Badger Pass Parking Area & Cirsium vulgare \\
\hline Big Oak Flat Road (5902) & Cirsium vulgare \\
\hline Bridalveil Falls - Inspiration Point & Cirsium vulgare \\
\hline Concession Stables (YV) & Cirsium vulgare \\
\hline Crane Flat Campground & Cirsium vulgare \\
\hline Curry Village & Cirsium vulgare \\
\hline Foresta East & Cirsium vulgare \\
\hline Foresta West & Cirsium vulgare \\
\hline Glacier Point Road (6440) & Cirsium vulgare \\
\hline Happy Isles & Cirsium vulgare \\
\hline Hodgdon Meadow Campground & Cirsium vulgare \\
\hline Housekeeping Camp & Cirsium vulgare \\
\hline Lower Pines Campground & Cirsium vulgare \\
\hline Mariposa Grove - Lower Grove & Cirsium vulgare \\
\hline Mariposa Grove - Upper & Cirsium vulgare \\
\hline Mariposa Grove Trail & Cirsium vulgare \\
\hline McCauley Ranch & Cirsium vulgare \\
\hline Meadow Loop Trail - Wawona & Cirsium vulgare \\
\hline Mirror Lake & Cirsium vulgare \\
\hline Mirror Lake Pack Trail & Cirsium vulgare \\
\hline North Pines Campground & Cirsium vulgare \\
\hline North Wawona-Central section & Cirsium vulgare \\
\hline North Wawona-Eastern section & Cirsium vulgare \\
\hline North Wawona-Western section & Cirsium vulgare \\
\hline Old Big Oak Flat Rd. Trail & Cirsium vulgare \\
\hline Panorama Trail & Cirsium vulgare \\
\hline Southside Drive & Cirsium vulgare \\
\hline Tioga Road (6254) & Cirsium vulgare \\
\hline Upper Pines Campground & Cirsium vulgare \\
\hline Wawona Campground & Cirsium vulgare \\
\hline Wawona Road (6051) & Cirsium vulgare \\
\hline Wawona Road 2 (5143) & Cirsium vulgare \\
\hline Wawona Road 3 (6040) & Cirsium vulgare \\
\hline Yosemite Lodge & Cirsium vulgare \\
\hline Yosemite Loop Trail & Cirsium vulgare \\
\hline Yosemite Village & Cirsium vulgare \\
\hline Yosemite West & Cirsium vulgare \\
\hline McCauley Ranch & Convolvulus arvensis \\
\hline Upper Old El Portal & Convolvulus arvensis \\
\hline Yosemite Village & Convolvulus arvensis \\
\hline Lower Old El Portal & Coreopsis lanceolata \\
\hline Big Oak Flat Road (4946) & Dactylis glomerata \\
\hline
\end{tabular}

\begin{tabular}{|c|c|c|}
\hline Site & Alien Species & Site Type \\
\hline Glacier Point Road (6440) & Cirsium vulgare & Road \\
\hline Glen Aulin High Sierra Camp & Poa pratensis & Camp \\
\hline Glen Aulin High Sierra Camp & Trifolium repens & Camp \\
\hline Glen Aulin Trail & Poa pratensis & Trail \\
\hline Glen Aulin Trail & Trifolium repens & Trail \\
\hline Government Corrals - Tuolumne & Poa pratensis & Stock \\
\hline Government Stables & Bromus tectorum & Stock \\
\hline Government Stables & Poa bulbosa & Stock \\
\hline Government Stables & Urtica urens & Stock \\
\hline Happy Isles & Agrostis gigantea & Trail \\
\hline Happy Isles & Bromus inermis & Trail \\
\hline Happy Isles & Bromus tectorum & Trail \\
\hline Happy Isles & Cirsium vulgare & Trail \\
\hline Happy Isles & Holcus lanatus & Trail \\
\hline Happy Isles & Marrubium vulgare & Trail \\
\hline Happy Isles & Poa pratensis & Trail \\
\hline Harden Lake Corral & Poa pratensis & Stock \\
\hline Harden Lake Corral & Trifolium repens & Stock \\
\hline Hetch Hetchy Backpacker's Camp & Bromus tectorum & Campground \\
\hline Hetch Hetchy Backpacker's Camp & Hypericum perforatum & Campground \\
\hline Hetch Hetchy Backpacker's Camp & Melilotus alba & Campground \\
\hline Hetch Hetchy Backpacker's Camp & Melilotus indica & Campground \\
\hline Hetch Hetchy Backpacker's Camp & Poa bulbosa & Campground \\
\hline Hetch Hetchy Backpacker's Camp & Poa pratensis & Campground \\
\hline Hetch Hetchy Backpacker's Camp & Tragopogon dubius & Campground \\
\hline Hetch Hetchy Corral & Bromus tectorum & Stock \\
\hline Hetch Hetchy Corral & Centaurea solstitialis & Stock \\
\hline Hetch Hetchy Corral & Poa bulbosa & Stock \\
\hline Hetch Hetchy Corral & Poa pratensis & Stock \\
\hline Hetch Hetchy Corral & Polypogon monspeliensis & Stock \\
\hline Hetch Hetchy Road (5505) & Bromus inermis & Road \\
\hline Hetch Hetchy Road (5505) & Bromus tectorum & Road \\
\hline Hetch Hetchy Road (5505) & Hypericum perforatum & Road \\
\hline Hodgdon Meadow Campground & Cirsium vulgare & Campground \\
\hline Hodgdon Meadow Campground & Holcus lanatus & Campground \\
\hline Hodgdon Meadow Campground & Phleum pratense & Campground \\
\hline Hodgdon Meadow Campground & Poa pratensis & Campground \\
\hline Hodgdon Meadow Campground & Tragopogon dubius & Campground \\
\hline Housekeeping Camp & Agrostis gigantea & Development \\
\hline Housekeeping Camp & Bromus inermis & Development \\
\hline Housekeeping Camp & Cirsium vulgare & Development \\
\hline Housekeeping Camp & Dactylis glomerata & Development \\
\hline Housekeeping Camp & Holcus lanatus & Development \\
\hline Housekeeping Camp & Lolium perenne & Development \\
\hline Housekeeping Camp & Rubus discolor & Development \\
\hline Housekeeping Camp & Verbascum thapsus & Development \\
\hline Inspiration Pt. Trail & Bromus tectorum & Trail \\
\hline Lower Old El Portal & Bromus inermis & Development \\
\hline Lower Old El Portal & Bromus tectorum & Development \\
\hline Lower Old El Portal & Centaurea solstitialis & Development \\
\hline Lower Old El Portal & Coreopsis lanceolata & Development \\
\hline
\end{tabular}


Appendix B. (continued)

\begin{tabular}{|c|c|}
\hline Site & Alien Species \\
\hline Concession Stables (YV) & Dactylis glomerata \\
\hline Curry Village & Dactylis glomerata \\
\hline Housekeeping Camp & Dactylis glomerata \\
\hline Lower Pines Campground & Dactylis glomerata \\
\hline Lower River Campground & Dactylis glomerata \\
\hline Meadow Loop Trail - Wawona & Dactylis glomerata \\
\hline Merced Grove trail & Dactylis glomerata \\
\hline Mirror Lake & Dactylis glomerata \\
\hline North Wawona-Central section & Dactylis glomerata \\
\hline North Wawona-Eastern section & Dactylis glomerata \\
\hline North Wawona-Western section & Dactylis glomerata \\
\hline Northside Drive & Dactylis glomerata \\
\hline Southside Drive & Dactylis glomerata \\
\hline The Ahwahnee hotel & Dactylis glomerata \\
\hline Tioga Road (6254) & Dactylis glomerata \\
\hline Tuolumne Concessions Stables & Dactylis glomerata \\
\hline Upper Old El Portal & Dactylis glomerata \\
\hline Upper Pines Campground & Dactylis glomerata \\
\hline Yosemite Lodge & Dactylis glomerata \\
\hline Foresta East & Digitalis purpurea \\
\hline North Wawona-Central section & Digitalis purpurea \\
\hline North Wawona-Eastern section & Digitalis purpurea \\
\hline North Wawona-Western section & Digitalis purpurea \\
\hline The Ahwahnee hotel & Erigeron strigosus \\
\hline Lower River Campground & Foeniculum vulgare \\
\hline Lower River Campground & Geranium robertianum \\
\hline Yosemite Village & Hedera helix \\
\hline Alder Creek Trail & Holcus lanatus \\
\hline Backpacker's Camp & Holcus lanatus \\
\hline Big Oak Flat Road (4661) & Holcus lanatus \\
\hline Big Oak Flat Road (5272) & Holcus lanatus \\
\hline Bridalveil Campground & Holcus lanatus \\
\hline Bridalveil Falls - Inspiration Point & Holcus lanatus \\
\hline Chilnualna Falls Trail & Holcus lanatus \\
\hline Concession Stables (YV) & Holcus lanatus \\
\hline Curry Village & Holcus lanatus \\
\hline Foresta East & Holcus lanatus \\
\hline Foresta West & Holcus lanatus \\
\hline Four-mile Trail & Holcus lanatus \\
\hline Happy Isles & Holcus lanatus \\
\hline Hodgdon Meadow Campground & Holcus lanatus \\
\hline Housekeeping Camp & Holcus lanatus \\
\hline Lower Pines Campground & Holcus lanatus \\
\hline Lower River Campground & Holcus lanatus \\
\hline Mariposa Grove - Lower Grove & Holcus lanatus \\
\hline Mariposa Grove Trail & Holcus lanatus \\
\hline McCauley Ranch & Holcus lanatus \\
\hline Meadow Loop Trail - Wawona & Holcus lanatus \\
\hline Mirror Lake & Holcus lanatus \\
\hline Mirror Lake Pack Trail & Holcus lanatus \\
\hline North Pines Campground & Holcus lanatus \\
\hline
\end{tabular}

\begin{tabular}{|c|c|c|}
\hline Site & Alien Species & Site Type \\
\hline Lower Old El Portal & Marrubium vulgare & Development \\
\hline Lower Old El Portal & Melilotus alba & Development \\
\hline Lower Old El Portal & Melilotus indica & Development \\
\hline Lower Old El Portal & Mentha spicata & Development \\
\hline Lower Old El Portal & Rubus discolor & Development \\
\hline Lower Old El Portal & Tragopogon dubius & Development \\
\hline Lower Old El Portal & Trifolium repens & Development \\
\hline Lower Old El Portal & Verbascum thapsus & Development \\
\hline Lower Old El Portal & Vinca major & Development \\
\hline Lower Pines Campground & Agrostis gigantea & Campground \\
\hline Lower Pines Campground & Bromus tectorum & Campground \\
\hline Lower Pines Campground & Cirsium vulgare & Campground \\
\hline Lower Pines Campground & Dactylis glomerata & Campground \\
\hline Lower Pines Campground & Holcus lanatus & Campground \\
\hline Lower Pines Campground & Phleum pratense & Campground \\
\hline Lower Pines Campground & Poa bulbosa & Campground \\
\hline Lower Pines Campground & Poa pratensis & Campground \\
\hline Lower Pines Campground & Rubus discolor & Campground \\
\hline Lower Pines Campground & Rubus lacinatus & Campground \\
\hline Lower Pines Campground & Trifolium repens & Campground \\
\hline Lower Pines Campground & Verbascum thapsus & Campground \\
\hline Lower River Campground & Agrostis gigantea & Campground \\
\hline Lower River Campground & Bromus inermis & Campground \\
\hline Lower River Campground & Bromus tectorum & Campground \\
\hline Lower River Campground & Carduus pycnocephalus & Campground \\
\hline Lower River Campground & Dactylis glomerata & Campground \\
\hline Lower River Campground & Foeniculum vulgare & Campground \\
\hline Lower River Campground & Geranium robertianum & Campground \\
\hline Lower River Campground & Holcus lanatus & Campground \\
\hline Lower River Campground & Hypericum perforatum & Campground \\
\hline Lower River Campground & Lolium perenne & Campground \\
\hline Lower River Campground & Marrubium vulgare & Campground \\
\hline Lower River Campground & Melilotus alba & Campground \\
\hline Lower River Campground & Poa bulbosa & Campground \\
\hline Lower River Campground & Poa pratensis & Campground \\
\hline Lower River Campground & Rubus discolor & Campground \\
\hline Lower River Campground & Tragopogon dubius & Campground \\
\hline Lower River Campground & Trifolium repens & Campground \\
\hline Lower River Campground & Verbascum thapsus & Campground \\
\hline Mariposa Grove - Lower Grove & Cirsium vulgare & Development \\
\hline Mariposa Grove - Lower Grove & Holcus lanatus & Development \\
\hline Mariposa Grove - Lower Grove & Poa pratensis & Development \\
\hline Mariposa Grove - Lower Grove & Verbascum thapsus & Development \\
\hline Mariposa Grove - Upper & Cirsium vulgare & Development \\
\hline Mariposa Grove - Upper & Poa pratensis & Development \\
\hline Mariposa Grove Trail & Bromus tectorum & Trail \\
\hline Mariposa Grove Trail & Cirsium vulgare & Trail \\
\hline Mariposa Grove Trail & Holcus lanatus & Trail \\
\hline Mariposa Grove Trail & Poa pratensis & Trail \\
\hline McCauley Ranch & Bromus inermis & Stock \\
\hline McCauley Ranch & Bromus tectorum & Stock \\
\hline
\end{tabular}


Appendix B. (continued)

\begin{tabular}{|c|c|}
\hline Site & Alien Species \\
\hline North Wawona-Central section & Holcus lanatus \\
\hline North Wawona-Eastern section & Holcus lanatus \\
\hline North Wawona-Western section & Holcus lanatus \\
\hline Old Big Oak Flat Rd. Trail & Holcus lanatus \\
\hline The Ahwahnee hotel & Holcus lanatus \\
\hline Upper Pines Campground & Holcus lanatus \\
\hline Wawona Campground & Holcus lanatus \\
\hline Wawona Road (3964) & Holcus lanatus \\
\hline Wawona Road (6051) & Holcus lanatus \\
\hline Wawona Stables & Holcus lanatus \\
\hline Yosemite Falls Trail & Holcus lanatus \\
\hline Yosemite Lodge & Holcus lanatus \\
\hline Yosemite Loop Trail & Holcus lanatus \\
\hline Yosemite Village & Holcus lanatus \\
\hline Alder Creek Trail & Hypericum perforatum \\
\hline Big Oak Flat Road (4661) & Hypericum perforatum \\
\hline Big Oak Flat Road (4946) & Hypericum perforatum \\
\hline Concession Stables (YV) & Hypericum perforatum \\
\hline Hetch Hetchy Backpacker's Camp & Hypericum perforatum \\
\hline Hetch Hetchy Road (5505) & Hypericum perforatum \\
\hline Lower River Campground & Hypericum perforatum \\
\hline McCauley Ranch & Hypericum perforatum \\
\hline Northside Drive & Hypericum perforatum \\
\hline The Ahwahnee hotel & Hypericum perforatum \\
\hline Wawona Road (3964) & Hypericum perforatum \\
\hline Yosemite Falls Trail & Hypericum perforatum \\
\hline Yosemite Loop Trail & Hypericum perforatum \\
\hline Yosemite Village & Hypericum perforatum \\
\hline Big Oak Flat Road (4946) & Lathyrus latifolius \\
\hline Foresta East & Lathyrus latifolius \\
\hline Meadow Loop Trail - Wawona & Lathyrus latifolius \\
\hline North Wawona-Central section & Lathyrus latifolius \\
\hline The Ahwahnee hotel & Lathyrus latifolius \\
\hline Upper Old El Portal & Lathyrus latifolius \\
\hline Upper Rancheria - El Portal & Lathyrus latifolius \\
\hline Yosemite Village & Lathyrus latifolius \\
\hline Concession Stables (YV) & Leucanthemum vulgare \\
\hline Foresta East & Leucanthemum vulgare \\
\hline Foresta West & Leucanthemum vulgare \\
\hline North Pines Campground & Leucanthemum vulgare \\
\hline North Wawona-Central section & Leucanthemum vulgare \\
\hline North Wawona-Eastern section & Leucanthemum vulgare \\
\hline Yosemite Lodge & Leucanthemum vulgare \\
\hline Concession Stables (YV) & Lolium perenne \\
\hline Curry Village & Lolium perenne \\
\hline Foresta West & Lolium perenne \\
\hline Housekeeping Camp & Lolium perenne \\
\hline Lower River Campground & Lolium perenne \\
\hline North Pines Campground & Lolium perenne \\
\hline North Wawona-Central section & Lolium perenne \\
\hline North Wawona-Eastern section & Lolium perenne \\
\hline
\end{tabular}

\begin{tabular}{|c|c|c|}
\hline Site & Alien Species & Site Type \\
\hline McCauley Ranch & Centaurea solstitialis & Stock \\
\hline McCauley Ranch & Cirsium vulgare & Stock \\
\hline McCauley Ranch & Convolvulus arvensis & Stock \\
\hline McCauley Ranch & Holcus lanatus & Stock \\
\hline McCauley Ranch & Hypericum perforatum & Stock \\
\hline McCauley Ranch & Phleum pratense & Stock \\
\hline McCauley Ranch & Poa pratensis & Stock \\
\hline McCauley Ranch & Rubus discolor & Stock \\
\hline McCauley Ranch & Tragopogon dubius & Stock \\
\hline McCauley Ranch & Trifolium repens & Stock \\
\hline McCauley Ranch & Verbascum thapsus & Stock \\
\hline Meadow Loop Trail - Wawona & Agrostis gigantea & Trail \\
\hline Meadow Loop Trail - Wawona & Bromus inermis & Trail \\
\hline Meadow Loop Trail - Wawona & Bromus tectorum & Trail \\
\hline Meadow Loop Trail - Wawona & Cirsium vulgare & Trail \\
\hline Meadow Loop Trail - Wawona & Dactylis glomerata & Trail \\
\hline Meadow Loop Trail - Wawona & Holcus lanatus & Trail \\
\hline Meadow Loop Trail - Wawona & Lathyrus latifolius & Trail \\
\hline Meadow Loop Trail - Wawona & Phleum pratense & Trail \\
\hline Meadow Loop Trail - Wawona & Poa bulbosa & Trail \\
\hline Meadow Loop Trail - Wawona & Poa pratensis & Trail \\
\hline Meadow Loop Trail - Wawona & Rubus discolor & Trail \\
\hline Meadow Loop Trail - Wawona & Rubus laciniatus & Trail \\
\hline Meadow Loop Trail - Wawona & Tragopogon dubius & Trail \\
\hline Meadow Loop Trail - Wawona & Trifolium repens & Trail \\
\hline Meadow Loop Trail - Wawona & Verbascum thapsus & Trail \\
\hline Merced Grove trail & Dactylis glomerata & Trail \\
\hline Mirror Lake & Agrostis gigantea & Development \\
\hline Mirror Lake & Bromus tectorum & Development \\
\hline Mirror Lake & Cirsium vulgare & Development \\
\hline Mirror Lake & Dactylis glomerata & Development \\
\hline Mirror Lake & Holcus lanatus & Development \\
\hline Mirror Lake & Poa pratensis & Development \\
\hline Mirror Lake & Rubus discolor & Development \\
\hline Mirror Lake Pack Trail & Bromus tectorum & Trail \\
\hline Mirror Lake Pack Trail & Cirsium vulgare & Trail \\
\hline Mirror Lake Pack Trail & Holcus lanatus & Trail \\
\hline Mirror Lake Pack Trail & Phleum pratense & Trail \\
\hline Mirror Lake Pack Trail & Poa pratensis & Trail \\
\hline Mirror Lake Pack Trail & Rubus discolor & Trail \\
\hline Mirror Lake Pack Trail & Trifolium repens & Trail \\
\hline North Pines Campground & Agrostis gigantea & Campground \\
\hline North Pines Campground & Bromus inermis & Campground \\
\hline North Pines Campground & Bromus tectorum & Campground \\
\hline North Pines Campground & Cirsium vulgare & Campground \\
\hline North Pines Campground & Holcus lanatus & Campground \\
\hline North Pines Campground & Leucanthemum vulgare & Campground \\
\hline North Pines Campground & Lolium perenne & Campground \\
\hline North Pines Campground & Poa bulbosa & Campground \\
\hline North Pines Campground & Poa pratensis & Campground \\
\hline North Pines Campground & Rubus discolor & Campground \\
\hline
\end{tabular}


Appendix B. (continued)

\begin{tabular}{|c|c|}
\hline Site & Alien Specie \\
\hline North Wawona-Western section & Lolium perenne \\
\hline Northside Drive & Lolium perenne \\
\hline Southside Drive & Lolium perenne \\
\hline Upper Old El Portal & Lolium perenne \\
\hline Upper Rancheria - El Portal & Lolium perenne \\
\hline Yosemite Lodge & Lolium perenne \\
\hline Yosemite Village & Lolium perenne \\
\hline Yosemite West & Lolium perenne \\
\hline Happy Isles & Marrubium vulgare \\
\hline Lower Old El Portal & Marrubium vulgare \\
\hline Lower River Campground & Marrubium vulgare \\
\hline Upper Old El Portal & Marrubium vulgare \\
\hline Upper Rancheria - El Portal & Marrubium vulgare \\
\hline Hetch Hetchy Backpacker's Camp & Melilotus alba \\
\hline Lower Old El Portal & Melilotus alba \\
\hline Lower River Campground & Melilotus alba \\
\hline Hetch Hetchy Backpacker's Camp & Melilotus indica \\
\hline Lower Old El Portal & Melilotus indica \\
\hline Upper Old El Portal & Melilotus indica \\
\hline Upper Rancheria - El Portal & Melilotus officinalis \\
\hline Lower Old EI Portal & Mentha spicata \\
\hline The Ahwahnee hotel & Mentha spicata \\
\hline Big Oak Flat Road (4661) & Phleum pratense \\
\hline Big Oak Flat Road (4946) & Phleum pratense \\
\hline Concession Stables (YV) & Phleum pratense \\
\hline Crane Flat Campground & Phleum pratense \\
\hline Curry Village & Phleum pratense \\
\hline Hodgdon Meadow Campground & Phleum pratense \\
\hline Lower Pines Campground & Phleum pratense \\
\hline McCauley Ranch & Phleum pratense \\
\hline Meadow Loop Trail - Wawona & Phleum pratense \\
\hline Mirror Lake Pack Trail & Phleum pratense \\
\hline North Wawona-Western section & Phleum pratense \\
\hline Yosemite Loop Trail & Phleum pratense \\
\hline Big Oak Flat Road (4661) & Poa bulbosa \\
\hline Big Oak Flat Road (4946) & Poa bulbosa \\
\hline Bridalveil Falls Trail & Poa bulbosa \\
\hline Concession Stables (YV) & Poa bulbosa \\
\hline El Portal Road & Poa bulbosa \\
\hline Four-mile Trail & Poa bulbosa \\
\hline Government Stables & Poa bulbosa \\
\hline Hetch Hetchy Backpacker's Camp & Poa bulbosa \\
\hline Hetch Hetchy Corral & Poa bulbosa \\
\hline Lower Pines Campground & Poa bulbosa \\
\hline Lower River Campground & Poa bulbosa \\
\hline Meadow Loop Trail - Wawona & Poa bulbosa \\
\hline North Pines Campground & Poa bulbosa \\
\hline North Wawona-Central section & Poa bulbosa \\
\hline North Wawona-Eastern section & Poa bulbosa \\
\hline North Wawona-Western section & Poa bulbosa \\
\hline Northside Drive & Poa bulbosa \\
\hline
\end{tabular}

\begin{tabular}{|c|c|c|}
\hline Site & Alien Species & Site Type \\
\hline North Pines Campground & Rubus lacinatus & Campground \\
\hline North Pines Campground & Verbascum thapsus & Campground \\
\hline North Wawona-Central section & Agrostis gigantea & Development \\
\hline North Wawona-Central section & Bromus inermis & Development \\
\hline North Wawona-Central section & Bromus tectorum & Development \\
\hline North Wawona-Central section & Cirsium vulgare & Development \\
\hline North Wawona-Central section & Dactylis glomerata & Development \\
\hline North Wawona-Central section & Digitalis purpurea & Development \\
\hline North Wawona-Central section & Holcus lanatus & Development \\
\hline North Wawona-Central section & Lathyrus latifolius & Development \\
\hline North Wawona-Central section & Leucanthemum vulgare & Development \\
\hline North Wawona-Central section & Lolium perenne & Development \\
\hline North Wawona-Central section & Poa bulbosa & Development \\
\hline North Wawona-Central section & Poa pratensis & Development \\
\hline North Wawona-Central section & Verbascum thapsus & Development \\
\hline North Wawona-Eastern section & Bromus tectorum & Development \\
\hline North Wawona-Eastern section & Cirsium vulgare & Development \\
\hline North Wawona-Eastern section & Dactylis glomerata & Development \\
\hline North Wawona-Eastern section & Digitalis purpurea & Development \\
\hline North Wawona-Eastern section & Holcus lanatus & Development \\
\hline North Wawona-Eastern section & Leucanthemum vulgare & Development \\
\hline North Wawona-Eastern section & Lolium perenne & Development \\
\hline North Wawona-Eastern section & Poa bulbosa & Development \\
\hline North Wawona-Eastern section & Poa pratensis & Development \\
\hline North Wawona-Eastern section & Rubus discolor & Development \\
\hline North Wawona-Eastern section & Trifolium repens & Development \\
\hline North Wawona-Eastern section & Verbascum thapsus & Development \\
\hline North Wawona-Western section & Agrostis gigantea & Development \\
\hline North Wawona-Western section & Bromus inermis & Development \\
\hline North Wawona-Western section & Bromus tectorum & Development \\
\hline North Wawona-Western section & Cirsium vulgare & Development \\
\hline North Wawona-Western section & Dactylis glomerata & Development \\
\hline North Wawona-Western section & Digitalis purpurea & Development \\
\hline North Wawona-Western section & Holcus lanatus & Development \\
\hline North Wawona-Western section & Lolium perenne & Development \\
\hline North Wawona-Western section & Phleum pratense & Development \\
\hline North Wawona-Western section & Poa bulbosa & Development \\
\hline North Wawona-Western section & Poa pratensis & Development \\
\hline North Wawona-Western section & Tanacetum parthenium & Development \\
\hline North Wawona-Western section & Trifolium repens & Development \\
\hline North Wawona-Western section & Verbascum thapsus & Development \\
\hline Northside Drive & Bromus tectorum & Road \\
\hline Northside Drive & Dactylis glomerata & Road \\
\hline Northside Drive & Hypericum perforatum & Road \\
\hline Northside Drive & Lolium perenne & Road \\
\hline Northside Drive & Poa bulbosa & Road \\
\hline Northside Drive & Poa pratensis & Road \\
\hline Northside Drive & Tragopogon dubius & Road \\
\hline Northside Drive & Trifolium repens & Road \\
\hline Old Big Oak Flat Rd. Trail & Agrostis gigantea & Trail \\
\hline Old Big Oak Flat Rd. Trail & Bromus tectorum & Trail \\
\hline
\end{tabular}


Appendix B. (continued)

\begin{tabular}{|c|c|}
\hline Site & Alien Species \\
\hline Southside Drive & Poa bulbosa \\
\hline Sunnyside Campground & Poa bulbosa \\
\hline Upper Pines Campground & Poa bulbosa \\
\hline Wawona Campground & Poa bulbosa \\
\hline Wawona Road (3964) & Poa bulbosa \\
\hline Wawona Stables & Poa bulbosa \\
\hline Yosemite Lodge & Poa bulbosa \\
\hline Yosemite Loop Trail & Poa bulbosa \\
\hline Yosemite Village & Poa bulbosa \\
\hline Chilnualna Falls Trail & Poa compressa \\
\hline Alder Creek Trail & Poa pratensis \\
\hline Backpacker's Camp & Poa pratensis \\
\hline Badger Pass Parking Area & Poa pratensis \\
\hline Badger Pass Ski Resort & Poa pratensis \\
\hline Big Oak Flat Road (5272) & Poa pratensis \\
\hline Bridalveil Campground & Poa pratensis \\
\hline Bridalveil Creek Trail & Poa pratensis \\
\hline Bridalveil Falls Trail & Poa pratensis \\
\hline Concession Stables (YV) & Poa pratensis \\
\hline Curry Village & Poa pratensis \\
\hline El Portal Road & Poa pratensis \\
\hline Foresta East & Poa pratensis \\
\hline Foresta West & Poa pratensis \\
\hline Four-mile Trail & Poa pratensis \\
\hline Glen Aulin High Sierra Camp & Poa pratensis \\
\hline Glen Aulin Trail & Poa pratensis \\
\hline Government Corrals - Tuolumne & Poa pratensis \\
\hline Happy Isles & Poa pratensis \\
\hline Harden Lake Corral & Poa pratensis \\
\hline Hetch Hetchy Backpacker's Camp & Poa pratensis \\
\hline Hetch Hetchy Corral & Poa pratensis \\
\hline Hodgdon Meadow Campground & Poa pratensis \\
\hline Lower Pines Campground & Poa pratensis \\
\hline Lower River Campground & Poa pratensis \\
\hline Mariposa Grove - Lower Grove & Poa pratensis \\
\hline Mariposa Grove - Upper & Poa pratensis \\
\hline Mariposa Grove Trail & Poa pratensis \\
\hline McCauley Ranch & Poa pratensis \\
\hline Meadow Loop Trail - Wawona & Poa pratensis \\
\hline Mirror Lake & Poa pratensis \\
\hline Mirror Lake Pack Trail & Poa pratensis \\
\hline North Pines Campground & Poa pratensis \\
\hline North Wawona-Central section & Poa pratensis \\
\hline North Wawona-Eastern section & Poa pratensis \\
\hline North Wawona-Western section & Poa pratensis \\
\hline Northside Drive & Poa pratensis \\
\hline Snow Creek Trail & Poa pratensis \\
\hline Southside Drive & Poa pratensis \\
\hline Tamarack Flat Campground & Poa pratensis \\
\hline The Ahwahnee hotel & Poa pratensis \\
\hline Tuolumne Concessions Stables & Poa pratensis \\
\hline
\end{tabular}

\begin{tabular}{|c|c|c|}
\hline Site & Alien Species & Site Type \\
\hline Old Big Oak Flat Rd. Trail & Cirsium vulgare & Trail \\
\hline Old Big Oak Flat Rd. Trail & Holcus lanatus & Trail \\
\hline Old Big Oak Flat Rd. Trail & Tragopogon dubius & Trail \\
\hline Panorama Trail & Bromus inermis & Trail \\
\hline Panorama Trail & Bromus tectorum & Trail \\
\hline Panorama Trail & Cirsium vulgare & Trail \\
\hline Snow Creek Trail & Agrostis gigantea & Trail \\
\hline Snow Creek Trail & Bromus tectorum & Trail \\
\hline Snow Creek Trail & Poa pratensis & Trail \\
\hline Southside Drive & Bromus tectorum & Road \\
\hline Southside Drive & Cirsium vulgare & Road \\
\hline Southside Drive & Dactylis glomerata & Road \\
\hline Southside Drive & Lolium perenne & Road \\
\hline Southside Drive & Poa bulbosa & Road \\
\hline Southside Drive & Poa pratensis & Road \\
\hline Southside Drive & Tragopogon dubius & Road \\
\hline Southside Drive & Trifolium repens & Road \\
\hline Southside Drive & Verbascum thapsus & Road \\
\hline Sunnyside Campground & Bromus tectorum & Campground \\
\hline Sunnyside Campground & Poa bulbosa & Campground \\
\hline Tamarack Flat Campground & Poa pratensis & Campground \\
\hline Tamarack Flat Campground & Trifolium repens & Campground \\
\hline The Ahwahnee hotel & Agrostis gigantea & Development \\
\hline The Ahwahnee hotel & Bromus inermis & Development \\
\hline The Ahwahnee hotel & Bromus tectoum & Development \\
\hline The Ahwahnee hotel & Dactylis glomerata & Development \\
\hline The Ahwahnee hotel & Erigeron strigosus & Development \\
\hline The Ahwahnee hotel & Holcus lanatus & Development \\
\hline The Ahwahnee hotel & Hypericum perforatums & Development \\
\hline The Ahwahnee hotel & Lathyrus latifolius & Development \\
\hline The Ahwahnee hotel & Mentha spicata & Development \\
\hline The Ahwahnee hotel & Poa pratensis & Development \\
\hline The Ahwahnee hotel & Rubus discolor & Development \\
\hline The Ahwahnee hotel & Rudbeckia hirta & Development \\
\hline The Ahwahnee hotel & Trifolium repens & Development \\
\hline The Ahwahnee hotel & Verbascum thapsus & Development \\
\hline Tioga Road (6254) & Cirsium vulgare & Road \\
\hline Tioga Road (6254) & Dactylis glomerata & Road \\
\hline Tioga Road (7981) & Bromus inermis & Road \\
\hline Tioga Road (8472) & Bromus tectorum & Road \\
\hline Tuolumne Concessions Stables & Dactylis glomerata & Stock \\
\hline Tuolumne Concessions Stables & Poa pratensis & Stock \\
\hline Tuolumne Concessions Stables & Trifolium repens & Stock \\
\hline Tuolumne Grove & Bromus inermis & Development \\
\hline Upper Old El Portal & Agrostis gigantea & Development \\
\hline Upper Old El Portal & Bromus inermis & Development \\
\hline Upper Old El Portal & Centaurea solstitialis & Development \\
\hline Upper Old El Portal & Convolvulus arvensis & Development \\
\hline Upper Old El Portal & Dactylis glomerata & Development \\
\hline Upper Old El Portal & Lathyrus latifolius & Development \\
\hline Upper Old El Portal & Lolium perenne & Development \\
\hline
\end{tabular}


Appendix B. (continued)

\begin{tabular}{|c|c|}
\hline Site & Alien Species \\
\hline Upper Pines Campground & Poa pratensis \\
\hline Upper Rancheria - El Portal & Poa pratensis \\
\hline Wawona Campground & Poa pratensis \\
\hline Wawona Road (3964) & Poa pratensis \\
\hline Wawona Road (6051) & Poa pratensis \\
\hline Wawona Road 2 (5143) & Poa pratensis \\
\hline Wawona Road 3 (6040) & Poa pratensis \\
\hline Wawona Stables & Poa pratensis \\
\hline White Wolf Corral & Poa pratensis \\
\hline Yosemite Lodge & Poa pratensis \\
\hline Yosemite Loop Trail & Poa pratensis \\
\hline Yosemite Village & Poa pratensis \\
\hline Yosemite West & Poa pratensis \\
\hline Young Lake Trail & Poa pratensis \\
\hline Hetch Hetchy Corral & Polypogon monspeliensis \\
\hline Backpacker's Camp & Rubus discolor \\
\hline Concession Stables (YV) & Rubus discolor \\
\hline Curry Village & Rubus discolor \\
\hline Housekeeping Camp & Rubus discolor \\
\hline Lower Old El Portal & Rubus discolor \\
\hline Lower Pines Campground & Rubus discolor \\
\hline Lower River Campground & Rubus discolor \\
\hline McCauley Ranch & Rubus discolor \\
\hline Meadow Loop Trail - Wawona & Rubus discolor \\
\hline Mirror Lake & Rubus discolor \\
\hline Mirror Lake Pack Trail & Rubus discolor \\
\hline North Pines Campground & Rubus discolor \\
\hline North Wawona-Eastern section & Rubus discolor \\
\hline The Ahwahnee hotel & Rubus discolor \\
\hline Upper Old El Portal & Rubus discolor \\
\hline Upper Rancheria - El Portal & Rubus discolor \\
\hline Yosemite Lodge & Rubus discolor \\
\hline Yosemite Loop Trail & Rubus discolor \\
\hline Yosemite Village & Rubus discolor \\
\hline Lower Pines Campground & Rubus lacinatus \\
\hline North Pines Campground & Rubus lacinatus \\
\hline Wawona Campground & Rubus lacinatus \\
\hline Meadow Loop Trail - Wawona & Rubus laciniatus \\
\hline The Ahwahnee hotel & Rudbeckia hirta \\
\hline North Wawona-Western section & Tanacetum parthenium \\
\hline Concession Stables (YV) & Tragopogon dubius \\
\hline Foresta East & Tragopogon dubius \\
\hline Foresta West & Tragopogon dubius \\
\hline Hetch Hetchy Backpacker's Camp & Tragopogon dubius \\
\hline Hodgdon Meadow Campground & Tragopogon dubius \\
\hline Lower Old El Portal & Tragopogon dubius \\
\hline Lower River Campground & Tragopogon dubius \\
\hline McCauley Ranch & Tragopogon dubius \\
\hline Meadow Loop Trail - Wawona & Tragopogon dubius \\
\hline Northside Drive & Tragopogon dubius \\
\hline Old Big Oak Flat Rd. Trail & Tragopogon dubius \\
\hline
\end{tabular}

\begin{tabular}{|c|c|c|}
\hline Site & Alien Species & Site Type \\
\hline Upper Old El Portal & Marrubium vulgare & Development \\
\hline Upper Old El Portal & Melilotus indica & Development \\
\hline Upper Old El Portal & Rubus discolor & Development \\
\hline Upper Old El Portal & Tragopogon dubius & Development \\
\hline Upper Old El Portal & Trifolium repens & Development \\
\hline Upper Old El Portal & Verbascum thapsus & Development \\
\hline Upper Old El Portal & Vinca major & Development \\
\hline Upper Pines Campground & Bromus tectorum & Campground \\
\hline Upper Pines Campground & Cirsium vulgare & Campground \\
\hline Upper Pines Campground & Dactylis glomerata & Campground \\
\hline Upper Pines Campground & Holcus lanatus & Campground \\
\hline Upper Pines Campground & Poa bulbosa & Campground \\
\hline Upper Pines Campground & Poa pratensis & Campground \\
\hline Upper Rancheria - El Portal & Bromus inermis & Development \\
\hline Upper Rancheria - El Portal & Bromus tectorum & Development \\
\hline Upper Rancheria - El Portal & Centaurea solstitialis & Development \\
\hline Upper Rancheria - El Portal & Lathyrus latifolius & Development \\
\hline Upper Rancheria - El Portal & Lolium perenne & Development \\
\hline Upper Rancheria - El Portal & Marrubium vulgare & Development \\
\hline Upper Rancheria - El Portal & Melilotus officinalis & Development \\
\hline Upper Rancheria - El Portal & Poa pratensis & Development \\
\hline Upper Rancheria - El Portal & Rubus discolor & Development \\
\hline Upper Rancheria - El Portal & Tragopogon dubius & Development \\
\hline Upper Rancheria - El Portal & Trifolium repens & Development \\
\hline Üpper Rancheria - El Portal & Verbascum thapsus & Development \\
\hline Upper Rancheria - El Portal & Vicia benghalensis & Development \\
\hline Wawona Campground & Bromus tectorum & Campground \\
\hline Wawona Campground & Cirsium vulgare & Campground \\
\hline Wawona Campground & Holcus lanatus & Campground \\
\hline Wawona Campground & Poa bulbosa & Campground \\
\hline Wawona Campground & Poa pratensis & Campground \\
\hline Wawona Campground & Rubus lacinatus & Campground \\
\hline Wawona Campground & Verbascum thapsus & Campground \\
\hline Wawona Road (3964) & Bromus tectorum & Road \\
\hline Wawona Road (3964) & Holcus lanatus & Road \\
\hline Wawona Road (3964) & Hypericum perforatum & Road \\
\hline Wawona Road (3964) & Poa bulbosa & Road \\
\hline Wawona Road (3964) & Poa pratensis & Road \\
\hline Wawona Road (6051) & Agrostis gigantea & Road \\
\hline Wawona Road (6051) & Bromus tectorum & Road \\
\hline Wawona Road (6051) & Cirsium vulgare & Road \\
\hline Wawona Road (6051) & Holcus lanatus & Road \\
\hline Wawona Road (6051) & Poa pratensis & Road \\
\hline Wawona Road (6051) & Trifolium repens & Road \\
\hline Wawona Road 2 (5143) & Bromus inermis & Road \\
\hline Wawona Road 2 (5143) & Bromus tectorum & Road \\
\hline Wawona Road 2 (5143) & Centaurea solstitialis & Road \\
\hline Wawona Road 2 (5143) & Cirsium vulgare & Road \\
\hline Wawona Road 2 (5143) & Poa pratensis & Road \\
\hline Wawona Road 3 (6040) & Agrostis gigantea & Road \\
\hline Wawona Road 3 (6040) & Bromus inermis & Road \\
\hline
\end{tabular}


Appendix B. (continued)

\begin{tabular}{|c|c|}
\hline Site & Alien Species \\
\hline Southside Drive & Tragopogon dubius \\
\hline Upper Old El Portal & Tragopogon dubius \\
\hline Upper Rancheria - El Portal & Tragopogon dubius \\
\hline Wawona Road 3 (6040) & Tragopogon dubius \\
\hline Yosemite Loop Trail & Tragopogon dubius \\
\hline Concession Stables (YV) & Trifolium repens \\
\hline Curry Village & Trifolium repens \\
\hline Foresta East & Trifolium repens \\
\hline Glen Aulin High Sierra Camp & Trifolium repens \\
\hline Glen Aulin Trail & Trifolium repens \\
\hline Harden Lake Corral & Trifolium repens \\
\hline Lower Old El Portal & Trifolium repens \\
\hline Lower Pines Campground & Trifolium repens \\
\hline Lower River Campground & Trifolium repens \\
\hline McCauley Ranch & Trifolium repens \\
\hline Meadow Loop Trail - Wawona & Trifolium repens \\
\hline Mirror Lake Pack Trail & Trifolium repens \\
\hline North Wawona-Eastern section & Trifolium repens \\
\hline North Wawona-Western section & Trifolium repens \\
\hline Northside Drive & Trifolium repens \\
\hline Southside Drive & Trifolium repens \\
\hline Tamarack Flat Campground & Trifolium repens \\
\hline The Ahwahnee hotel & Trifolium repens \\
\hline Tuolumne Concessions Stables & Trifolium repens \\
\hline Upper Old El Portal & Trifolium repens \\
\hline Upper Rancheria - El Portal & Trifolium repens \\
\hline Wawona Road (6051) & Trifolium repens \\
\hline White Wolf Corral & Trifolium repens \\
\hline Yosemite West & Trifolium repens \\
\hline Government Stables & Urtica urens \\
\hline Backpacker's Camp & Verbascum thapsus \\
\hline Badger Pass Parking Area & Verbascum thapsus \\
\hline Concession Stables (YV) & Verbascum thapsus \\
\hline Foresta West & Verbascum thapsus \\
\hline Housekeeping Camp & Verbascum thapsus \\
\hline Lower Old El Portal & Verbascum thapsus \\
\hline Lower Pines Campground & Verbascum thapsus \\
\hline Lower River Campground & Verbascum thapsus \\
\hline Mariposa Grove - Lower Grove & Verbascum thapsus \\
\hline McCauley Ranch & Verbascum thapsus \\
\hline Meadow Loop Trail - Wawona & Verbascum thapsus \\
\hline North Pines Campground & Verbascum thapsus \\
\hline North Wawona-Central section & Verbascum thapsus \\
\hline North Wawona-Eastern section & Verbascum thapsus \\
\hline North Wawona-Western section & Verbascum thapsus \\
\hline Southside Drive & Verbascum thapsus \\
\hline The Ahwahnee hotel & Verbascum thapsus \\
\hline Upper Old El Portal & Verbascum thapsus \\
\hline Upper Rancheria - El Portal & Verbascum thapsus \\
\hline Wawona Campground & Verbascum thapsus \\
\hline Yosemite Lodge & Verbascum thapsus \\
\hline
\end{tabular}

\begin{tabular}{|c|c|c|}
\hline Site & Alien Species & Site Type \\
\hline Wawona Road $3(6040)$ & Bromus tectorum & Road \\
\hline Wawona Road $3(6040)$ & Cirsium vulgare & Road \\
\hline Wawona Road 3 (6040) & Poa pratensis & Road \\
\hline Wawona Road 3 (6040) & Tragopogon dubius & Road \\
\hline Wawona Stables & Bromus tectorum & Stock \\
\hline Wawona Stables & Holcus lanatus & Stock \\
\hline Wawona Stables & Poa bulbosa & Stock \\
\hline Wawona Stables & Poa pratensis & Stock \\
\hline White Wolf Corral & Poa pratensis & Stock \\
\hline White Wolf Corral & Trifolium repens & Stock \\
\hline Yosemite Falls Trail & Bromus tectorum & Trail \\
\hline Yosemite Falls Trail & Holcus lanatus & Trail \\
\hline Yosemite Falls Trail & Hypericum perforatum & Trail \\
\hline Yosemite Lodge & Agrostis gigantea & Development \\
\hline Yosemite Lodge & Bromus inermis & Development \\
\hline Yosemite Lodge & Bromus tectorum & Development \\
\hline Yosemite Lodge & Cirsium vulgare & Development \\
\hline Yosemite Lodge & Dactylis glomerata & Development \\
\hline Yosemite Lodge & Holcus lanatus & Development \\
\hline Yosemite Lodge & Leucanthemum vulgare & Development \\
\hline Yosemite Lodge & Lolium perenne & Development \\
\hline Yosemite Lodge & Poa bulbosa & Development \\
\hline Yosemite Lodge & Poa pratensis & Development \\
\hline Yosemite Lodge & Rubus discolor & Development \\
\hline Yosemite Lodge & Verbascum thapsus & Development \\
\hline Yosemite Loop Trail & Agrostis gigantea & Trail \\
\hline Yosemite Loop Trail & Bromus tectorum & Trail \\
\hline Yosemite Loop Trail & Cirsium vulgare & Trail \\
\hline Yosemite Loop Trail & Holcus lanatus & Trail \\
\hline Yosemite Loop Trail & Hypericum perforatum & Trail \\
\hline Yosemite Loop Trail & Phleum pratense & Trail \\
\hline Yosemite Loop Trail & Poa bulbosa & Trail \\
\hline Yosemite Loop Trail & Poa pratensis & Trail \\
\hline Yosemite Loop Trail & Rubus discolor & Trail \\
\hline Yosemite Loop Trail & Tragopogon dubius & Trail \\
\hline Yosemite Loop Trail & Verbascum thapsus & Trail \\
\hline Yosemite Village & Agrostis gigantea & Development \\
\hline Yosemite Village & Bromus inermis & Development \\
\hline Yosemite Village & Bromus tectorum & Development \\
\hline Yosemite Village & Cirsium vulgare & Development \\
\hline Yosemite Village & Convolvulus arvensis & Development \\
\hline Yosemite Village & Hedera helix & Development \\
\hline Yosemite Village & Holcus lanatus & Development \\
\hline Yosemite Village & Hypericum perforatum & Development \\
\hline Yosemite Village & Lathyrus latifolius & Development \\
\hline Yosemite Village & Lolium perenne & Development \\
\hline Yosemite Village & Poa bulbosa & Development \\
\hline Yosemite Village & Poa pratensis & Development \\
\hline Yosemite Village & Rubus discolor & Development \\
\hline Yosemite Village & Vitis vinifera & Development \\
\hline Yosemite West & Bromus tectorum & Road \\
\hline
\end{tabular}


Appendix B. (continued)

\begin{tabular}{|l|l|}
\hline \multicolumn{1}{|c|}{ Site } & \multicolumn{1}{c|}{ Alien Species } \\
\hline Yosemite Loop Trail & Verbascum thapsus \\
Yosemite West & Verbascum thapsus \\
Upper Rancheria - El Portal & Vicia benghalensis \\
Lower Old El Portal & Vinca major \\
Upper Old El Portal & Vinca major \\
Yosemite Village & Vitis vinifera \\
\hline
\end{tabular}

\begin{tabular}{|lll|}
\hline \multicolumn{1}{|c|}{ Site } & \multicolumn{1}{c|}{ Alien Species } & \multicolumn{1}{c|}{ Site Type } \\
\hline Yosemite West & Cirsium vulgare & Road \\
Yosemite West & Lolium perenne & Road \\
Yosemite West & Poa pratensis & Road \\
Yosemite West & Trifolium repens & Road \\
Yosemite West & Verbascum thapsus & Road \\
Young Lake Trail & Poa pratensis & Trail \\
\hline
\end{tabular}


Appendix C. Field notes of Sequoia-Kings Canyon National Park survey crews.

\section{Ash Mountain Headquarters}

Ampelopsis arborea - One population, apparently a residual planting, was found near house \#97 in the headquarters area. This population of approximately a dozen individuals was growing near the foundation of an erstwhile structure, now an open grassy area.

Arundo donax - A large clump approximately 5 meters by 10 meters was observed along the far western edge of the large maintenance parking lot. A large, straggling colony grew on an exposed, grassy slope in the back yard of house \#14.

Carduus pycnocephalus - Thousands of these plants grew in many places around Ash Mountain, especially in shaded or moist grassy areas.

Cistus sp. - One planted population of approximately 10 individuals was observed adjacent to the Administration Building; this was the only population observed within the Ash Mountain area.

Dactylis glomerata - Thousands of plants grew in the shaded, unmowed lawn of Quarters 96. This is the only population observed in the Ash Mountain area in 1997 and 1998.

Eucalyptus citriodora - One plant was found on an exposed grassy slope bordering a dirt parking lot on the east side of Highway 198. This tree had been chopped down and was resprouting from the base.

Festuca arundinacea - Collected in lawn between the Research Office and the Sequoia Natural History Association Building in the Ash Mountain Headquarters. One colony, consisting of a few dozen plants, was found 50 meters north of the footbridge at the western edge of crescent meadow in a level, moist, shaded area.
Genista monspessulana - Thousands of these plants were scattered widely about Ash Mountain Headquarters. Very few individuals appeared more than a few years old, likely due to eradication efforts by park employees. One especially dense colony hosted over 1000 individuals and was located 15 meters northeast of the laundry room under a dense canopy of Quercus wislizenii var wislizenii. Most common in partly shaded grassy areas, this species appeared well dispersed around headquarters, but we did not see any outside of this developed area.

Hedera helix - Cultivated in several places about Ash Mountain Headquarters, this species does not appear to have naturalized.

Heteromeles arbutifolia - This species is native to much of California, but not to the Kaweah River drainage. It is widely planted and naturalized around Ash Mountain Headquarters, with thousands of plants sighted during the surveys. It was common in grassy areas in all sunlight regimes. Very few plants were seen outside of the developed areas.

Lathyrus latifolius - One colony of several dozen plants grew at headquarters in an open grassy field bounded on all sides by structures and roadways. This population was likely a residual planting.

Leucojum aestivum - Hundreds of plants grew about the Research Center in unwatered flowerbeds and in adjacent unwatered grassy areas. This species appears to reproduce sexually and asexually in this area. This is the first collection for Sequoia-Kings Canyon National Parks.

Ligustrum sinense - Dozens of privet hedges are cultivated in landscaped areas about Ash Mountain Headquarters. None appear to be naturalizing.

Melilotus indica - These plants grew in a few scattered populations, mainly along grassy roadsides in the Ash Mountain Complex. No more than a few dozen individuals were sighted in the entire survey area. 
Poa bulbosa - Dozens of plants grew 15 meters northwest of Quarters 9 in an exposed, flat, disturbed, sandy parking lot. Thousands of plants grew throughout Ash Mountain in partly shaded, disturbed, grassy areas.

Poa pratensis - We found fewer than ten plants in an irregularly watered lawn near the Research Office, Ash Mountain Headquarters. Observed only in the headquarters area, this plant was seen by the hundreds in a watered lawn just north of the Administration Building.

Polypogon monspeliensis - Collected in the Ash Mountain Headquarters parking lot. It has been seen elsewhere in more naturalized areas such as Alder Creek and the Ash Mountain pastures.

Oxalis pes-caprae - Thousands of plants grew five meters southwest of the Research Center in a gently sloping, north-facing, grassy area around a concrete-lined pond. Colonies of this plant are common about the Ash Mountain developed area.

Punica granatum - One plant was found growing alongside a footpath leading down to the Middle Fork of the Kaweah River. It appeared to be more than 20 years old and had no offspring visible near it. It seems unlikely that this plant was intentionally cultivated.

Pyracantha angustifolia - Hundreds of individuals were scattered about the headquarters area in grassy places. This widely planted species appears to naturalize in watered and unwatered areas alike. Naturalized individuals observed during the Ash Mountain surveys were limited to the Headquarters area. Two other naturalized plants were seen in nearby riparian areas, one in Sycamore Creek and one in the Middle Fork of the Kaweah River, just upstream of headquarters (see associated survey reports).

Spartium junceum - This plant has several distinct populations throughout the Ash Mountain area as well as along the Middle Fork of the Kaweah near the park boundary. A single population of fewer than one hundred individuals was found along the north side of the
Generals Highway on a steep road cut fifty meters west of the Alder Creek bridge. Another population was seen in the lower Ash Mountain housing area near residence \#88's garage. One mature shrub with several smaller shrubs are here. Other scattered individuals are infrequent throughout the Ash Mountain survey area.

Trifolium repens - Thousands of plants grew in the watered lawn surrounding the Administration Building.

Vicia sativa - A single, small colony was observed near Cricket Hollow along an old asphalt use road that parallels the Generals Highway on the north side. Two other colonies were observed in the Ash Mountain area adjacent to the Generals Highway. Three populations of this plant were observed in the Ash Mountain area. All were on partly shaded, grassy slopes bordering roadways. There were hundreds of plants in each colony.

Vinca major - Numerous patches (on the order of several square meters each) of this plant were scattered about and restricted to the Ash Mountain Headquarters area. All appear to be either maintained or residual plantings.

\section{Ash Mountain Entrance Station}

Catalpa bignonioides - One tree grew alongside a road/parking area within 100 meters of the park boundary on the west side of the Kaweah River. It appeared to have been planted there; its trunk was about 50 centimeters in diameter at 1.7 meters above the ground.

\section{Ash Mountain Flume}

Medicago sativa - Three hardy, vegetative plants were observed within 200 meters of each other along the flume. All grew in shade on or alongside the footpath.

\section{Ash Mountain Slash Pits}

Urtica urens - Fewer than ten plants grew at the south end of the Ash Mountain Slash Pits on exposed, disturbed soil bordering human waste compost. 


\section{Atwell Mill Campground}

Poa pratensis - Thousands of individuals were scattered throughout the campground in undisturbed, moist soils.

Trifolium repens - A population of greater than 1000 individuals was seen growing in a wet seep with a dense herbaceous layer in well developed, saturated soil. No other populations were observed throughout the campground.

\section{Azalea Campground}

Bromus tectorum - Several small populations, totaling fewer than 100 plants, grew in the southwest part of the campground in a disturbed, party shaded meadow margin.

Cirsium vulgare - Hundreds of rosettes were scattered in moist places throughout the campground.

Holcus lanatus - Thousands of plants grew in moist, disturbed places about the campground.

Phalaris arundinacea - A population of over 100 individuals was observed 20 meters west of the SW corner of Azalea Campground in the center of an undisturbed montane meadow. The population was growing out of a rotting fallen $\log$ that was in standing water. This is the wettest site that this species was observed growing in 1998. Scattered small patches were observed in moist sites within the campground as well. Dozens of plants grew in a level, sunny, disturbed seep in the middle of the campground.

Poa bulbosa - Fewer than ten plants grew in the southwest part of the campground in a disturbed, party shaded meadow margin.

Poa pratensis - Hundreds of plants were scattered in moist places about Azalea Campground.

Verbascum thapsus - We observed one population containing dozens of plants in a lush, disturbed, partly shaded seep.
Verbascum virgatum - Dozens of plants grew in a moist, flat, disturbed, sunny area near the middle of the campground.

\section{Big Stump Picnic Area}

Bromus tectorum - Thousands of plants grew throughout the parking area in sandy, disturbed soils.

Poa pratensis - Dozens of plants grew throughout the parking area in sandy, disturbed soils.

Tragopogon dubius - One plant grew near the entrance to the Big Stump Parking Area in sandy, disturbed soil.

\section{Buckeye Campground}

Bromus tectorum - Thousands of these plants grew in sunny areas on the east side of the campground.

Poa bulbosa - This species was widespread about the campground in disturbed and undisturbed, open areas. It was especially common around campground the perimeter where grassland began.

Marrubium vulgare - Thousands of these plants grew in dense patches in the southern part of the campground.

\section{Cahoon Meadow}

Poa pratensis - A small population of fewer than 10 individuals was seen growing in Calhoun Meadow adjacent to a $10 \mathrm{~m}$ deep, cut stream bank. No other populations were seen in this meadow. 


\section{Camp Conifer}

Bromus tectorum - This was from a $1 \times 2$ square meter colony in a exposed roadside area on the old road leading up to Camp Conifer.

Poa compressa - This plant was part of a small colony that was growing on a moist, old dirt roadbed near Camp Conifer.

Verbascum thapsus - This plant was scattered sparsely in wet, old dirt roadbeds around Camp Conifer.

\section{Cedar Grove Market and Lodge}

Bromus tectorum - Tens of thousands of plants grew in open places throughout the market area. This species is abundant in the Cedar Grove Valley and does not appear to be restricted to human disturbance.

Melilotus alba - A single population consisting of fewer than 100 plants grew in exposed, sandy, trampled soil adjacent to the laundromat.

Poa bulbosa - Hundreds of plants grew about the market area in sandy soils. They appeared to be restricted to human disturbance.

Poa pratensis - We found one population containing hundreds of individuals near the laundromat in exposed, sandy soil. The soil appeared damp due to leaky plumbing.

\section{Cedar Grove Pack Station}

Bromus tectorum - Tens of thousands of these plants infested every habitable patch of soil in and around the pack station. They were abundant in many parts of the Cedar Grove area, apparently not restricted to human disturbance.

Phalaris minor - One plant grew alongside a corral in partly shaded, grassy, disturbed duff on a gentle, south-facing slope. First collection for Sequoia-Kings Canyon National Parks.

Poa bulbosa - Thousands of these plants grew on dirt roadbeds and margins of highly disturbed areas about the pack station. This species appeared restricted to the pack station complex.
Polypogon australis - Dozens of individuals grew in the silty manure of an exposed, unused corral 40 meters north of the tack shed.

Polypogon monspeliensis - There were a few small, scattered patches of this species in the less trampled areas of the pack station complex.

Trifolium repens - We found one plant at the south end of the pack station in shaded, trampled, mesic duff.

Urtica urens - We saw dozens of these plants is two small populations near the corral margins in manure-enriched soil. This species appeared restricted to the pack station complex.

\section{Cedar Grove Road}

Bromus tectorum - Thousands of plants grew in open, sunny places throughout the survey area. This species is abundant throughout the Cedar Grove Valley and does not seem restricted to human disturbance.

Cirsium vulgare - Dozens of plants grew in moist places along the Cedar Grove Road. They did not appear to be restricted to human disturbance.

Festuca arundinacea - Hundreds of plants grew along the south side of the Cedar Grove Road, two kilometers west of Road's End. They were restricted to the roadside and grew in moderately shaded, decomposed granite soil.

Holcus lanatus - A single, large colony stretched approximately 50 meters along the south side of the road. The population was growing in well-drained, disturbed, granitic soil. We did not observe any individuals further than 5 meters from the road.

Lolium perenne - Three clumps were observed within 25 meters of one another approximately 2 kilometers east of the Roaring River Bridge on the south side of the road. They were growing adjacent to the road in sandy, disturbed soil. 
Poa bulbosa - We found one colony of hundreds of plants alongside a sunny parking lot in decomposed granite soil 100 meters northeast of the Roaring River Bridge.

Poa pratensis - Hundreds of plants grew in moist, shaded, well-vegetated, decomposed granite soil three kilometers west of Road's End.

Tragopogon dubius - We saw dozens of these plants scattered far and wide in many sunlight and moisture regimes. They did not appear to be restricted to human disturbance.

Verbascum thapsus - Hundreds of vegetative plants grew along the south side of the Cedar Grove Road in exposed, decomposed granite soil 300 meters east northeast of the Roaring River Bridge. This species appeared to be restricted to the road margin.

\section{Cherry Flat Trail}

Poa bulbosa - We found one population along the trail from Cherry Flat to Redwood Creek. Dozens of plants grew in a steep, partly shaded, sandy trailside area.

\section{Cold Springs Campground}

Digitalis purpurea - A population of fewer than 1000 individuals was observed growing on the north side of the bridge leading to the campground. Much of the population was growing in a watered, manicured lawn. Many individuals were scattered near the lawn in less disturbed, unwatered sites. The cabin next to the lawn had a wooden sign: "The Wollenmans".

Poa pratensis - Fewer than 1000 individuals were seen scattered throughout the campground in moist roadsides.

Verbascum thapsus - A single vegetative individual was seen on the west end of the campground adjacent to the walk-in campsite parking area. It was growing in moderately disturbed, well drained, granitic soil. No other individuals were observed throughout the campground.

\section{Colony Mill Road}

Bromus tectorum - Dozens of individuals growing directly on the roadbed near the gate that marks the Sequoia National Park Boundary. Several hundred individuals were observed scattered along the road corridor in open, disturbed, compacted soil.

Carduus pycnocephalus - Thousands of individuals growing directly on the roadbed near the gate that marks the Sequoia National Park Boundary.

Morus alba - One tree was growing in a stream alongside the lower end of the Colony Mill Road. The trunk diameter at 1.7 meters was approximately 60 centimeters.

\section{Columbine Picnic Area}

Cirsium vulgare - Hundreds of plants grew in a partly shaded ecotone between white fir forest and montane meadow. This area was moderately disturbed, gently sloping, west-facing, and well vegetated.

Dactylis glomerata - One colony of thousands of individuals grew on a stream bank in the Columbine Picnic Area.

Phalaris arundinacea - Hundreds of plants grew in the north edge of the picnic area in a well vegetated, partly shaded seep adjacent to a trail. This is likely Agrostis gigantea but we are unsure yet.

Poa pratensis - Thousands of plants grew in a partly shaded ecotone between white fir forest and montane meadow. This area was gently sloping, west-facing, and well vegetated. This plant was not restricted to disturbed places.

Trifolium repens - Hundreds of plants grew in a partly shaded ecotone between white fir forest and montane meadow. This area was moderately disturbed, gently sloping, west-facing, and well vegetated. 


\section{Crescent Meadow Trail}

Festuca pratensis - One colony, consisting of a few dozen plants, was found 50 meters north of the footbridge at the western edge of crescent meadow in a level, moist, shaded area.

Phleum pratense - There were several individuals observed along the west edge of Crescent Meadow growing out of rock cracks and compacted disturbed soil. There are scattered individuals all throughout the meadow margin. Another small population was observed at Round Meadow. A single population of fewer than 10 individuals was observed on the west margin of Crescent Meadow in a moderately disturbed, moist, partly shaded area.

Poa pratensis - Thousands of individuals were observed throughout the meadow in both open and shaded areas.

\section{Crystal Cave Parking Lot}

Bromus tectorum - Fewer than 1000 individuals were found along the edges of the parking lot in disturbed, partly shaded soils.

Prunus persica - This is almost surely the cultivated peach. Four trees grew around the periphery of the parking lot. Two of the trees appeared to have been planted and the other two were saplings, growing near the mature ones.

Tragopogon dubius - Fewer than 100 individuals were seen growing near the entrance of the parking lot along the road.

Vulpia bromoides - Fewer than 1000 individuals were found growing along the edges of the parking lot in disturbed, partly shaded soils.

\section{Crystal Cave Road}

Echinochloa crus-galli - Along the north edge of the Crystal Cave road on a well-drained, south facing, sunny slope. This site burned in 1969.

\section{Crystal Springs Campground}

Cirsium vulgare - Hundreds of plants were scattered throughout Crystal Springs Campground, most commonly in moist, meadow margins.

Poa pratensis - Hundreds of plants grew throughout the campground in both moist, disturbed and moist, undisturbed areas.

\section{Deadman Canyon Trail}

Poa pratensis - Hundreds of plants grew on a sunny stream bank alongside a trail 150 meters southeast of the Roaring River Ranger Station.

\section{Dorst Campground}

Cirsium vulgare - A population of several hundred individuals was observed on a gently sloping, south-facing hillside with well drained, sandy, granitic soils with a moderately dense herbaceous layer. No other populations were observed growing in the survey area.

Dactylis glomerata - Six plants were found on the east side of the campground near the entrance/registration station. They were growing around the concrete base of a recreational vehicle dump station in disturbed, partly shaded, decomposed granite soil. They were clearly receiving anthropogenic water.

Festuca arundinacea - One clump was found along a well vegetated, partly shaded roadside near the middle of the campground. First collection for Sequoia-Kings Canyon National Parks.

Melilotus alba - Fewer than 100 mature plants were scattered throughout the campground in the late fall. The plants were observed in open areas with sparse herbaceous under story. There were numerous seedlings of this species scattered throughout the area.

Melilotus officinalis - A late-season survey revealed one plant growing in the partly shaded, gently sloping, east-facing, disturbed soil of a campsite near the Amphitheater. This is the first collection for Sequoia-Kings Canyon National Parks. 
Poa pratensis - Two populations of fewer than 100 individuals were found growing along the edge of a wet montane meadow in moist, well developed soil.

Tragopogon dubius - Hundreds of individuals were seen scattered throughout the campground.

Trifolium repens - Fewer than 1000 individuals were seen scattered throughout the campground in open, dry, disturbed, sandy areas.

Verbascum thapsus - Fewer than 1000 individuals were encountered throughout the campground. Most of the plants were seen on disturbed soils adjacent to roads and trails.

\section{Elk Creek Trail, Middle Fork Kaweah}

Carduus pycnocephalus - This was collected from a $6 \mathrm{~m} \times 10 \mathrm{~m}$ patch. The patch was located in an open area surrounded by dense Adenostoma faciculatum along the Chamise Creek Trail.

\section{Eli's Paradise Meadow}

Dactylis glomerata - In Giant Forest at Eli's Paradise Meadow (Sunset Campground).

Digitalis purpurea - Many hundreds of these plants grew in Eli's Paradise, a montane meadow about 500 meters northwest of Round Meadow. They were especially common along the broad southeast margin of the meadow, where there was little standing water.

\section{Ferguson Creek Area}

Cirsium vulgare - This montane meadow, which is 2.5 kilometers east of Sugarloaf Peak, had hundreds of plants scattered throughout it.

\section{General's Highway}

Centaurea solstitialis - Three plants grew along the east side of the Generals Highway one kilometer south of Potwisha Campground. About a dozen plants were eradicated between Potwisha Campground and Ash Mountain immediately following detection of these individuals. All grew along the east side of the road in fresh fill dirt, presumably imported during road construction in 1997. A follow-up survey of the entire road between Ash Mountain and Potwisha was done within the week by Resource Management staff. During their search, they encountered another six individuals scattered along the road. In December another individual was found at this location that had already set seed. There is a potential that there will be more individuals at this location and along the road for the next few years.

Dactylis glomerata - Two hundred meters west of The Wye along the Generals Highway; single population of 6 individuals adjacent to the south edge of the highway in sandy, well-drained soil.

Melilotus indica - Thousands of these plants grew throughout the road corridor in loose soil. They were not common in the surrounding undisturbed grassland.

Oxalis pes-caprae - Thousands of plants grew on a road-cut 125 meters north of the Ash Mountain Visitor Center. This 30 meter section of roadside was the only place we saw Oxalis between Ash Mountain and Potwisha Campground.

Phalaris paradoxa - Two distinct populations of approximately one hundred individuals each were observed adjacent to the Generals Highway in the vicinity of the Ash Mt. Entrance Station. Both populations are located adjacent to the roadway in open, moist seeps. A single individual was also observed between the Middle Fork Flume and the parking lot/staging area below the entrance station.

Sorghum halepense - Dozens of plants were seen in a colony on an exposed roadside area 1.5 kilometers south along the Generals Highway from Amphitheater Point.

Spartium junceum - Dozens of plants grew in one distinct colony about 75 meters north of the Ash Mountain Visitor Center. This roadside colony appears to have originated from Ash Mountain government housing, just upslope from the road. 
Tragopogon dubius - One plant was found alongside the Generals Highway across from the former lodging area in a partly shaded dirt "pullout". Five individuals were seen growing where the Generals Highway bisects Halstead Meadow in a sandy berm. All five plants were pulled up.

Vicia sativa - Several plants grew 125 meters north of the Ash Mountain Visitor Center along the west edge of the Generals Highway on a steep, east-facing road cut. We saw thousands more along the General's Highway.

Vicia villosa - One plant grew along the east side of the Generals Highway 1.5 kilometers south of Potwisha Campground. This roadside has been re-vegetated following last year's road construction. Another individual grew under similar conditions 1 kilometer north.

Vinca major - We saw one dense 75 square meter colony 100 meters north of the Ash Mountain Visitor Center. It grew along the shaded south bank of Alder Creek near the west margin of the Generals Highway.

\section{Giant Forest Developed Area}

Dactylis glomerata - A population of fewer than 10 individuals was observed growing along the road to Lower Kaweah Housing on the west side of the Giant Forest Lodge in partly disturbed, partly shaded, sandy, granitic soil. Other populations of this plant were seen in Giant Forest at Eli's Paradise Meadow (Sunset Campground) and at Round Meadow. Thousands of individuals were seen scattered throughout the meadow edge, primarily on the west and north edges along the "Trail for All People". The plants radiate into the adjacent Big Tree Forest for several meters. Other populations of this species were observed along the asphalt road to Lower Kaweah on the west side of the Giant Forest Lodge.

Digitalis purpurea - Many hundreds of these plants grew in Eli's Paradise, a montane meadow about 500 meters northwest of Round Meadow. They were especially common along the broad southeast margin of the meadow, where there was little standing water. A single plant was seen growing adjacent to the asphalt roadway leading to the Puzzle Tree on a steep road cut in well-drained, granitic soil with a sparse duff layer.
Poa bulbosa - A colony of fewer than 100 individuals was seen growing directly in front of the Giant Forest Lodge adjacent to a dirt footpath in moderately disturbed, partly shaded, well developed soil

Poa pratensis - A population of fewer than 100 individuals was seen growing in front of the Giant Forest Lodge adjacent to concrete steps in partly shaded ground. There are frequent populations throughout Giant Forest in moist, undisturbed sites.

Tragopogon dubius - One plant was found alongside the Generals Highway across from the former lodging area in a partly shaded dirt "pullout".

Verbascum thapsus - A single rosette was seen growing in front of the Giant Forest Lodge in partly shaded, disturbed soil.

\section{Giant Forest Sewage Plant}

Bromus tectorum - Thousands of individuals were seen growing around the Giant Forest Sewage Treatment Facility in open, poorly developed and well developed soils. No other populations were seen in the Giant Forest area.

Cirsium vulgare - A single plant was observed near the Giant Forest Sewage Treatment Facility. There were abundant individuals scattered throughout Giant Forest in both disturbed and undisturbed sites.

Rubus sp. - One robust colony grew at the base of a sewage treatment structure in $50 \%$ shade. It is likely a cultivated species dispersed by feces.

\section{Grant Grove Developed Area}

Cirsium vulgare - One rosette grew on a gently sloping, south-facing, disturbed meadow margin near the market.

Digitalis purpurea - Hundreds of plants grew in the housing area and in the adjacent forested areas in more mesic, undisturbed sites. 
Holcus lanatus - A large colony of over 1000 individuals was observed approximately 50 meters north of Grant Grove Market in an open, moderately disturbed, level site between an asphalt road and moist montane meadow.

Phalaris arundinacea - Thousands of plants grew in a partly shaded stream 50 meters south of Wilsonia. These plants were abundant in many streams about Grant Grove, often dominating herbaceous cover. This appears to be Agrostis gigantea but final identification is pending. A large colony of several thousand individuals were observed along the north edge of the meadow behind the Grant Grove Market. The population was growing along the meadow margin in disturbed, sandy soil. This is the only population observed in this meadow. There are several other populations of this species throughout the Grant Grove Area. A small clump of three individuals was observed 40 meters east of the Maintenance Building/Fire House on a berm adjacent to the large parking lot. Thousands of plants grew in dense colonies in many wet areas about Grant Grove.

Phleum pratense - Hundreds of plants grew on the east edge of the market area on a trampled, partly shaded meadow margin.

Poa pratensis - Hundreds of plants grew on the east edge of the market area on a trampled, partly shaded meadow margin. This species was scattered throughout the survey area in moist places. Hundreds of plants grew about the housing area and they were common on meadow margins.

Tanacetum parthenium - A single plant was observed in an exposed, nearly flat clearing within the Wilsonia area in loose, disturbed soil.

Trifolium repens - Hundreds of plants grew throughout the Grant Grove developed area in clumps scattered about disturbed, moist places.

Verbascum thapsus - Dozens of plants were scattered throughout the housing area. Fewer than ten individuals were observed 40 meters east of the Maintenance Building/Fire House on a berm adjacent to the large parking lot.

\section{Grant Grove Pack Station}

Phalaris arundinacea - Dozens of plants grew at the northwest edge of the pack station in partly shaded duff and horse manure. They appeared to be restricted to anthropogenic disturbance. Dozens of plants grew at the south end of the pack station in a densely vegetated unused corral.

Urtica urens - Thousands of plants formed a dense colony in an unused corral at the south end of the corral complex. Others were scattered about the corral margins. A number of plants spilled down a south-facing, dry streambed at the south edge of the pack station as well. Other than the streambed individuals, $U$. urens appeared to be restricted to the pack station complex.

\section{Grasshopper Meadow}

Poa pratensis - Thousands of plants grew throughout Grasshopper Meadow, 1.5 kilometers southeast of Roaring River Ranger Station.

\section{Grunnigan Ranch}

Carya sp. - One tree was found at the edge of a field bordering Yucca Creek. This mature tree appeared to be a residual planting.

Diospyros sp. - A dense, 200-square-meter stand of trees up to 15 meters tall was observed along the eastern edge of a clearing within the Grunnigan Ranch site. The trees were apparently reproducing vegetatively. No additional populations were seen within the survey site nor in the adjacent Yucca creek.

Nerium oleander - This lone large shrub grew between Yucca Creek and the Old Hidden Springs Road near an old house foundation in a south facing, anthropogenic clearing. No other individuals were observed in the area. This is the first collection for Sequoia-Kings Canyon National Parks. 
Olea europaea - Five mature trees bearing fruit were found approximately $200 \mathrm{~m}$ from Yucca creek along the Old Hidden Springs road. There are no apparent young saplings in the vicinity. There are, however, shoots growing from bases of the boles. First collection for Sequoia-Kings Canyon National Parks.

Punica granatum - One individual, almost surely a residual planting, was found. It was in a partly shaded grassy area, 100 meters east of where the Old Hidden Springs Road crosses Yucca Creek.

Pyracantha angustifolia - Several mature shrubs were observed in a 10-square-meter thicket along the western edge of a large clearing in the former Grunnigan Ranch site. No other populations were observed within the ranch area. This apparently was a residual planting.

Rubus discolor - There was a dense patch in an open field at the former site of the Grunnigan Ranch. The patch was oval in shape and was approximately 35 meters long by 24 meters wide. $R$. discolor was also abundant in nearby Yucca Creek between Grunnigan Ranch and the North Fork of the Kaweah.

\section{Halstead Meadow}

Poa pratensis - Thousands of individuals were observed 10 meters south of the Generals Highway on the west side of the meadow. The plants were growing in an open, wet meadow in well developed, moist soil. Scattered individuals were seen throughout the meadow, especially along the meadow edge.

Tragopogon dubius - Five individuals were seen growing where the Generals Highway bisects the meadow in a sandy berm. All five plants were pulled up.

\section{High Sierra Trail}

Bromus tectorum - Collected along trail approximately $1 \mathrm{~km}$ east of Bearpaw Ranger Station on the trail towards Kaweah Gap. There are scattered patches of Bromus tectorum all along the trail in this area. B. tectorum can be seen at least $100 \mathrm{~m}$ below the trail here. It would appears to be not dependent on the trail.
Poa pratensis - Collected alongside the trail growing with Bromus tectorum and Vulpia myuros ssp. hirsuta.

\section{Hockett Meadow and Pasture}

Phleum pratense - Fewer than 100 individuals were observed alongside the trail to Evelyn Lake approximately $0.5 \mathrm{~km}$ from Hockett Meadow. The population was growing in a wet lodgepole forest with a dense herbaceous understory. A few small populations of this plant species were seen in and about Hockett Meadow growing in disturbed, trailside areas as well as in relatively undisturbed, streamside areas. Phleum alpinum, the native timothy, was much more abundant than P. pratense.

Poa pratensis - Thousands of individuals were seen growing 150 meters southeast of the Hockett Meadow Ranger Station along the horse pasture fence.

\section{Hospital Rock}

Carduus pycnocephalus - One plant grew adjacent to the parking lot in a crack between a cement curb and some compacted soil.

Lolium perenne - Hundreds of plants grew in scattered clumps in grassy areas and asphalt cracks throughout the picnic area

Poa pratensis - Hundreds of plants were found beneath a mature Umbellularia californica.

Polypogon monspeliensis - Fewer than ten plants grew alongside the Generals Highway in a moist, disturbed ditch at the north edge of the survey area.

\section{JR Meadow}

Poa pratensis - Thousands of plants grew throughout J. R. Meadow, 300 meters northwest of the Roaring River Ranger Station. This meadow sees annual grazing. 


\section{Kern Ranger Station}

Poa pratensis - Collected in the Kern Ranger Station Stock Pasture

\section{Lewis Creek Trail}

Bromus tectorum - Though not as abundant as on the floor of the Cedar Grove Valley, B. tectorum was still common in open patches in several places along the trail. The thousands of plants we saw were not restricted to areas of human disturbance.

Poa pratensis - Dozens of plants grew at a stream crossing several kilometers north of the trailhead. These plants grew in moderately disturbed, partly shaded, saturated, stream bank soil.

\section{Lodgepole Campground}

Bromus tectorum - Fewer than 1000 individuals were seen growing in the campground on the north side of the river in dry, open, granitic soils.

Poa bulbosa - Thousands of individuals were seen within the campground 50 meters south of the Marble Fork. They were in disturbed, sandy, well drained soil with a sparse herbaceous understory.

Poa pratensis - A population of fewer than one hundred individuals was observed within the campground on the south side of the river in a moist, partly disturbed area.

\section{Lodgepole Developed Area}

Cirsium vulgare - A population of fewer than 10 individuals was seen growing approximately 20 $m$ west of the Lodgepole Visitor Center adjacent to a concrete walkway. The population was in moderately disturbed, well drained granitic soil.

Dactylis glomerata - Two individuals were seen 50 meters south of the Visitor Center adjacent to a dirt footpath in moderately disturbed, open, granitic soil. Another individual was seen on the north side of the river.
Digitalis purpurea - Two individuals were observed on the north side of the river adjacent to an asphalt road that leads to the Lodgepole Fire House. They grew in moderately disturbed, well-drained, granitic soils.

Iris sp. - A single vegetative Iris species grew on the north side of the river on a steep slope adjacent to a large asphalt parking lot. Another individual was observed growing adjacent to a deserted government residence. These apparently were escaped cultivars.

Phalaris arundinacea - Forty meters west of the Lodgepole Visitor Center and adjacent to an asphalt parking lot in a nearly flat, open disturbed site with well-drained, granitic soil.

Verbascum thapsus - A population of three individuals was observed 20 meters south of the Lodgepole Fire Station adjacent to an asphalt parking lot. All three individuals were pulled up.

Verbascum virgatum - A single population of fewer than 10 individuals was observed on the north side of the river adjacent to an asphalt road that leads to the Lodgepole Fire House. The population was in moderately disturbed, welldrained, granitic soil. No other populations were seen throughout the survey area.

\section{Marble Fork of the Kaweah River}

Rubus discolor - A distinct patch of fewer than 100 individuals was caught growing in a three meter by three meter area on the banks of the Marble Fork of the Kaweah River near the Generals Highway bridge. The population was growing in partial shade.

\section{Marvin Pass Trail}

Cirsium vulgare - Hundreds of these plants grew in a. small meadow three kilometers northwest of the Roaring River Ranger Station. They did not appear to be dependant on anthropogenic disturbance.

Holcus lanatus - Dozens of plants grew in the center of the Roaring River Trail three kilometers northwest of the Roaring River Ranger Station. They grew in a moderately sloping, southeast-facing, trampled, sunny seep. 
Poa pratensis - Thousands of plants grew in Comanche Meadow, roughly 6 kilometers westsouthwest of the confluence of Sugarloaf Creek and Roaring River.

\section{Middle Fork Flume}

Bromus tectorum - This plant was collected in a flat, open area directly adjacent to the concrete flume wall. It is abundant throughout the survey area. This is the lowest elevation that this plant has been observed this year.

\section{Middle Fork of the Kaweah River}

Echinochloa crus-galli - Fewer than ten plants grew along the moist, mossy, shaded, moderately sloping, north-facing east bank of the Kaweah River, 800 meters upstream of the park boundary.

Ficus carica - A single individual, approximately one meter tall, was seen on the south side of the river just below the Research Center in a rocky area. We attempted to pull the plant up but some of the roots remained.

Morus alba - A single individual approximately two meters tall was seen in a shaded, dry, cobbled swale on the north side of the river. No other individuals were seen in the survey area.

Polypogon monspeliensis - This population was growing in a moist, flat sandbar 100 meters upstream of where the trail from Ash Mountain Headquarters leads to the river. The population is along a natural diversion from the main water course on the $\mathrm{W}$ side of the river. There are frequent populations of this species throughout the corridor in perennially moist sites. A large, dense colony of over 10,000 individuals was observed on the south side of the river approximately $1 \mathrm{~km} \mathrm{E}$ of Ash Mountain Headquarters. The population formed a dense colony in a area with well developed soil and very dense herbs with standing water in the center. Much of this population was growing directly out of standing water.
Pyracantha angustifolia - A few scattered mature shrubs were observed growing in a flat cobbled, floodplain 150 meters upstream of where the trail from Ash Mountain Headquarters leads to the river. There are individuals on both sides of the river.

Spartium junceum - Hundreds of plants were growing on the rocky floodplain on the west bank of the river. It appeared that most of the above-ground plant material was scoured off during winter flood events, but shoots were resprouting vigorously. This population is periodically cut back by park personnel.

Tamarix sp. - A single vegetative seedling was found in a moist sand bar during the fall survey of the river.

\section{Milk Ranch Lookout}

Bromus tectorum - Over 1000 individuals were observed scattered throughout the open, disturbed, dirt parking area/clearing $15 \mathrm{~m}$ south of the Milk Ranch Fire Tower.

Poa bulbosa - Over 1000 individuals were observed scattered throughout the open, disturbed, dirt parking area/clearing $15 \mathrm{~m}$ south of the Milk Ranch Fire Tower.

\section{Milk Ranch Road}

Cirsium vulgare - Fewer than 1000 individuals of this plant were seen outside of the park boundary along the road to Milk Ranch scattered throughout a clearing/meadow along the west side of the road.

Medicago sativa - One plant was observed approximately $1 \mathrm{~km}$ south of Milk Ranch Lookout adjacent to the Milk Ranch road. It was growing in compact, well drained sandy soil within a moderately dense herbaceous layer. No other plants were observed nearby. 


\section{Mineral King Pack Station}

Poa pratensis - This was found throughout the pack station complex along roadsides in less disturbed areas. It is present further from the complex further than other exotics. This plant was collected from a small colony in an undisturbed area of the meadow below the pack station.

Trifolium repens - This species grew in moist, disturbed places throughout the survey area.

Urtica urens - Scattered clumps were observed growing in disturbed soil directly next to the fence posts of the corral. No other vegetation was growing nearby.

Verbascum thapsus - This plant was collected from the roadside near the pack station.

\section{Moraine Campground}

Bromus tectorum - Thousands of these plants grew throughout Cedar Grove in open, sandy places. They were not restricted to human disturbance.

\section{Muir Grove}

Cirsium vulgare - Fewer than ten individuals were observed growing beneath the big trees of Muir Grove in loose duff.

\section{North Fork of the Kaweah River}

Echinochloa crus-galli - A single population of fewer than 10 individuals was observed along the bank of the river. No other individuals were seen within the survey area.

Piptatherum miliaceum - A single population of this plant was observed in the North Fork river corridor growing out of metasedimentary rock cracks.
Polypogon monspeliensis - Fewer than 100 vegetative plants were seen scattered in dry rock cracks adjacent to the river.

Mentha pulegium - Dozens of plants were found in partly shaded, rocky and sandy places in and adjacent to the floodplain of the Kaweah River along the lower end of the survey area. First collection for Sequoia-Kings Canyon National Parks.

Mentha spicata - A few small populations were found in well-shaded floodplains at the middle and upper reaches of the survey area. First collection for Sequoia-Kings Canyon National Parks.

Rubus discolor - Six populations, each with a diameter of two meters, were observed in the survey area.

Tamarix sp. - This vegetative plant appears to be a species of Tamarix, salt cedar. Two seedlings were seen in the North Fork, in a low, moist, sunny sand bar, at the park boundary. Seedlings were also seen in low moist sand bars in the Middle Fork of the Kaweah River, and in one of its tributaries, Sycamore Creek. No seedlings were over 15 centimeters tall, and all appeared to have established this season. It appeared very likely that all the seedlings sighted in the surveys were destined to be washed away in winter runoff, as all were in low, moist, recently deposited sandbars. This is the first collection for Sequoia-Kings Canyon National Parks.

Verbascum thapsus - Two vegetative rosettes were seen in a dry, sandy, open section of the riverbank approximately $150 \mathrm{~m}$ upstream of the confluence with Yucca creek.

\section{North Fork Parking Lot}

Carduus pycnocephalus - Fewer than 100 vegetative individuals were observed scattered along the lower parking lot margins in shaded, moderately disturbed sites. 


\section{Old Hidden Springs Road}

Cirsium vulgare - Fewer than ten individuals were observed growing where a perennial stream crosses the road within a shaded, gently sloping, S-facing hillside. The site was less than one kilometer from Hidden Springs. No plants of this species were seen any closer to Hidden Springs.

Silybum marianum - This straggling rosette was growing out of cow manure in the shade of planted Olea europaea L. trees. Numerous flowering individuals of this species were subsequently found in nearby Yucca Creek.

Vicia benghalensis - One large colony was found nine kilometers up Old Hidden Springs Road in Blue Oak Woodland. In this area the road cuts across an open, grassy, moderately sloping, north-facing hillside. This colony measured 20x40 meters and constituted approximately $90 \%$ of the groundcover. The colony was centered on the roadbed, but also crept into adjacent undisturbed grassland. This is the first collection for Sequoia-Kings Canyon National Parks.

\section{Oriole Lake Airstrip}

Vulpia bromoides - Thousands of these plants were observed scattered throughout the western half of the Oriole Lake Airstrip growing in welldrained, granitic soils.

\section{Oriole Lake Meadow}

Bromus tectorum - Thousands of individuals were throughout a moderately disturbed wet montane meadow $200 \mathrm{~m}$ north of the Oriole Lake Airstrip. The meadow had signs of cattle grazing this year.

Trifolium repens - Fewer than 100 individuals grew in small colonies throughout a moderately disturbed wet montane meadow 200 meters north of the Oriole Lake Airstrip. The meadow had signs of recent cattle grazing. Thousands of individuals were observed along the north edge of the Oriole Lake Airstrip and along the dirt road 25 meters north of the airstrip. Fewer than 100 individuals in small colonies were observed in a moderately disturbed wet montane meadow $200 \mathrm{~m}$ north of the Oriole Lake Airstrip. The meadow had signs of cattle grazing this year.

Verbascum thapsus - Fewer than 1000 individuals were scattered throughout a moderately disturbed wet montane meadow 200 $\mathrm{m}$ north of the Oriole Lake Airstrip. The meadow had signs of cattle grazing this year.

\section{Oriole Lake Road}

Bromus tectorum - Thousands of individuals were observed $25 \mathrm{~m}$ north of the Oriole Lake Airstrip adjacent to a maintained dirt road in a moist, open, partly disturbed area.

Poa pratensis - Fewer than 1000 individuals were observed $25 \mathrm{~m}$ north of the Oriole Lake Airstrip adjacent to a maintained dirt road in a moist, open, partly disturbed area.

Trifolium repens - Thousands of individuals were observed along the north edge of the Oriole Lake Airstrip and along the dirt road 25 meters north of the airstrip

Verbascum thapsus - Fewer than 1000 individuals were observed $25 \mathrm{~m}$ north of the Oriole Lake Airstrip adjacent to a maintained dirt road in a moist, open, partly disturbed area.

\section{Potwisha Campground}

Carduus pycnocephalus - A single colony of several hundred individuals was sighted along the east edge of the campground. The colony was approximately $6 \mathrm{~m}$ by $2 \mathrm{~m}$. No other individuals were observed throughout the survey area.

Convolvulus arvensis - One plant grew along the north side of the entrance to Potwisha Campground among annual grasses in partly shaded, sandy soil. First collection for SequoiaKings Canyon National Parks. 
Marrubium vulgare - Thousands of these plants grew throughout the campground in open to partly shaded areas of moderate disturbance. In some places, dense colonies of hundreds of individuals excluded all other vegetation. Park maintenance workers report a marked increase in population size in recent years.

Poa bulbosa - Thousands of these plants were observed scattered throughout the entire campground in both disturbed and undisturbed sites.

Poa pratensis - A population of fewer than one hundred individuals were observed at the northeast edge of the campground. They were growing amidst annual grasses on a moderately steep hillside in the shade of Quercus wislizenii var. wislizenii. No other populations were observed within the survey area.

Ranunculus parviflorus - Thousands of these plants were seen in dense clusters in shaded areas throughout the campground.

Rubus discolor - One population consisting of fewer than ten individuals was recorded. It was in the northeast end of the campground growing in the middle of a very dense colony of Marrubium vulgare near campsite 29 in partial shade. There also were dozens of individuals growing in a three-square-meter area on the partly shaded west bank of the Kaweah River near the Marble Fork bridge.

Urtica urens - Hundreds of individuals were seen throughout the campground in scattered clumps in loose, recently disturbed mineral soil. No individuals were observed in undisturbed areas of the campground.

Vinca major - A single colony was observed in a nearly flat area along the western edge of the campground at the base of an interior live oak tree. The colony completely covered a 50square-meter area. No other populations were observed in the campground. This appeared to be a residual planting.

Vulpia bromoides - A large colony of greater than 1000 individuals was seen at the end of the dirt road adjacent to the flume on the north side of the campground in sandy, compacted, open, moderately disturbed soil. No other populations were observed throughout the campground.

\section{Rae Lakes Loop Trail}

Bromus tectorum - Hundreds of plants grew 20 meters north of where the Mist Falls Trail crosses Bubb's Creek. They grew in patches on exposed, sandy soil and did not appear to be restricted to human disturbance. We saw hundreds of individuals growing in open patches along the Mist Falls Trail, they did not appear to be restricted to human disturbance. B. tectorum seemed less abundant here than farther down the valley nearer the developed areas. Dozens of plants grew along the trail in sandy soil among granite boulders. Thousands of plants grew along the Mist Falls Trail in open, sandy places. Hundreds of plants grew in a shaded, gently sloping, wooded area near the lower Paradise Valley Campground. Hundreds of plants grew along the Paradise Valley Trail in an exposed, recently burned area five kilometers north of Mist Falls. Thousands of plants grew on an exposed, sandy slope along the Bubb's Creek Trail three kilometers west of the Charlotte Creek Crossing. These plants were common along the switchbacks from the Sphinx Creek Crossing to the valley floor. SEE MAP we saw thousands of individuals along the Bubb's Creek Trail in sandy soil, they did not appear to be restricted to human disturbance. Hundreds of plants grew along the Bubb's Creek Trail in a partly shaded sandy area one kilometer north of Charlotte Creek. This was the highest population we saw on the Bubb's Creek Trail.

Cirsium vulgare - We saw dozens of plants at stream crossings, the plants seemed concentrated at areas of human disturbance. Hundreds of plants grew in a moist, shaded area alongside the Mist Falls Trail, three kilometers east of Road's End. Dozens of plants grew in a dry, sandy streambed along the Bubb's Creek Trail 100 meters east of its junction with the Mist Falls Trail. One vegetative individual grew on the partly shaded edge of a wet meadow. Hundreds of plants grew alongside the Bubb's Creek Trail on a steep, south-facing, sandy slope three kilometers west of the Charlotte Creek Crossing. Numerous plants grew in an adjacent stream. 
Hundreds of plants grew in a stream near the Bubb's Creek Trail three kilometers west of Charlotte Creek. They were not restricted to the trailside.

Echinochloa crus-galli - Single plant was observed along the trail margin in a nearly flat site with sandy, well-drained, granitic soil.

Poa pratensis - Hundreds of plants grew along the Rae Lakes Loop Trail in a moist seep adjacent to a small, unnamed meadow above Vidette Meadow. Hundreds of plants grew in the heavily grazed stock camp at Junction Meadow. Dozens of plants grew in the open drier sites within Castle Domes Meadow. The meadow had signs of being grazed by stock this year. Thousands of plants grew in a grazed meadow near the Rae Lakes Trail in the vicinity of Woods Creek. Hundreds of these plants grew on stream banks along the first kilometer of the Mist Falls Trail. They did not appear restricted to areas of human disturbance. Hundreds of plants grew in a stream near the Bubb's Creek Trail three kilometers west of Charlotte Creek. They were not restricted to the trailside. Hundreds of plants grew adjacent to the trail on exposed, moist soil.

Verbascum thapsus - We saw dozens of plants at stream crossings, the plants seemed concentrated at areas of human disturbance.

\section{Rattlesnake Creek Trail}

Poa pratensis - This plant was collected at a stream crossing of a tributary of Rattlesnake Creek. This was on the trail between Franklin Pass and the Kern Canyon.

\section{Red Fir Maintenance Area}

Bromus tectorum - Thousands of individuals were observed growing throughout the survey area in open, well drained, sandy, granitic soils.

Cirsium vulgare - Fewer than 100 individuals were observed scattered throughout the spray field adjacent to a moderately used dirt road leading through the middle of the site. Several rosettes were observed outside of the radius of the sprinklers. Fewer than 1000 individuals were seen scattered throughout the survey area. A large population was observed in a small drainage east of the maintenance building.

Poa pratensis - Fewer than 10 individuals were seen growing between the two maintenance buildings adjacent to an asphalt parking lot in nearly flat, disturbed granitic soil.

Verbascum virgatum - Fewer than one hundred individuals were observed scattered along the west side of the lower maintenance building in small moist ditch. Other individuals were scattered throughout the survey area in open sandy soils adjacent to asphalt roadways.

\section{Redwood Canyon Trail}

Cirsium vulgare - Fewer than ten plants grew in shaded, well developed, moist soil alongside the Redwood Creek Trail 50 meters northeast of the junction with the Hart Loop Trail. One plant grew in an exposed, well-vegetated sand bar in Redwood Creek.

Trifolium repens - Dozens of plants grew in moist, moderately shaded, well-developed soil near the Redwood Creek Trail just below Redwood Saddle.

\section{Redwood Creek}

Bromus tectorum - Collected in a disturbed area near the Redwood Creek Parking area on the Mineral King Road.

Poa pratensis - Collected in a disturbed area near the Redwood Creek Parking area on the Mineral King Road.

Rubus discolor - A large, dense population was observed within the creek bed from the roadside to about 50 meters upstream. Two other patches were observed downstream of the Mineral King Road. One patch was directly below the road and covered an area of approximately $8 \mathrm{~m}$ by $12 \mathrm{~m}$. The other patch was further downstream and was only $1 \mathrm{~m}$ by $2 \mathrm{~m}$. Both populations were growing directly in the creek. 
Trifolium repens - Several colonies were scattered in moist, disturbed areas.

\section{Scaffold Meadow}

Phleum pratense - Thousands of plants grew throughout scaffold Meadow, 300 meters north of Roaring River Ranger Station. This meadow receives heavy annual grazing from pack animals. The population often dominated the herb layer in several areas within the meadow. Phleum pratense was much more common than its native sympatric brother, $P$. alpinum.

Poa pratensis - Thousands of plants grew throughout Scaffold Meadow, 300 meters north of Roaring River Ranger Station. The plants were observed in both wet and dry sites in this meadow. Scaffold Meadow receives heavy annual grazing from pack animals.

\section{Sentinel Campground}

Ranunculus testiculatus - A single dense population of greater than 1000 individuals was observed in a moderately disturbed area on the east edge of the campground in well-drained, granitic soil. This is the only population of this species that we observed in 1998. First collection for Sequoia-Kings Canyon National Parks.

\section{Sequoia Lake Trail}

Cirsium vulgare - A single individual was observed adjacent to a small, flowing drainage in moist, well-developed soil. We pulled the plant up.

Poa pratensis - Dozens of plants grew in a steep, rocky streambed along the Sequoia Lakes Trail.

\section{Sheep Creek Campground}

Bromus tectorum - We saw thousands plants in sunny places about the campground. This species is abundant in the Cedar Grove Valley and does not appear to be dependant on human disturbance.
Poa bulbosa - We found one population in a dry, partly shaded, roadside ditch near campsite \#13.

Poa compressa - A colony of fewer than 100 individuals was observed growing near the east edge of the campground in a moist, sandy swale, adjacent to a paved campground road. No other populations were observed within the survey area.

Poa pratensis - We saw two populations in the campground, neither contained more than 100 plants. One grew at the base of a water spigot and the other grew in a dry, roadside ditch.

\section{Sheppard Saddle Road}

Polypogon monspeliensis - 100 meters west of Ash Mountain Shooting Range in a roadside ditch. The population is emergent out of $5 \mathrm{~cm}$ of standing water.

\section{South Fork Campground}

Carduus pycnocephalus - A few individuals were found in the middle part of the campground in a partly shaded, moderately sloping, northwest-facing, grassy area.

Cirsium vulgare - Dozens of individuals were found in the middle part of the campground near campsite \#5. They were growing in a partly shaded, moderately sloping, northwest-facing, grassy area. Last years flowering stalks were visible there, too. C. vulgare was not sighted elsewhere in the campground.

Tragopogon dubius - Eleven plants were found (and killed) in a partly shaded grassy area with a dry streambed running through it. They were in the western part of the campground. No other populations were found.

Vulpia bromoides - Hundreds of these plants were scattered throughout the campground in both moderately disturbed and undisturbed, grassy areas. 


\section{Sugar Bowl Trail}

Bromus tectorum - Hundreds of plants grew among giant sequoia seedlings in well drained soil on an exposed, moderately sloping, eastfacing, recently burned clearing.

Cirsium vulgare - One plant grew among giant sequoia seedlings in well drained soil on an exposed, moderately sloping, east-facing, recently burned clearing.

\section{Sugarloaf Meadow}

Poa pratensis - Thousands of plants grew around the meadow margin. This meadow sees heavy annual stock use.

\section{Sunset Campground}

Bromus tectorum - Fewer than 100 of these individuals were observed in dry, developed soil $5 \mathrm{~m}$ from the northwest edge of Eli's Paradise Meadow. This is the former site of Sunset Campground, which closed in the late 1960's.

Cirsium vulgare - Thousands of these individuals were seen growing throughout Eli's Paradise Meadow and radiating into the adjacent big tree forest in both disturbed and undisturbed sites in partial shade with well developed soils. This is the former site of Sunset Campground, which closed in the late 1960's.

Dactylis glomerata - Fewer than 1000 individuals were observed scattered along the margins of Eli's Paradise Meadow in partly shaded, moist soil with dense herbaceous understory. This is the former site of Sunset Campground, which closed in the late 1960's.

Digitalis purpurea - Many hundreds of these plants grew in Eli's Paradise, a montane meadow about 500 meters northwest of Round Meadow. They were especially common along the broad southeast margin of the meadow, where there was little standing water. This plant was documented in disturbed areas of both Lodgepole Pine and Big Tree Forest community types in 1997 surveys. This is the former site of Sunset Campground, which closed in the late 1960's.
Poa pratensis - Fewer than 1000 individuals were observed growing in small populations along the margins of Eli's Paradise Meadow in partly shaded, moist soil with dense herbaceous understory. This is the former site of Sunset Campground, which closed in the late 1960's.

Verbascum thapsus - Fewer than 100 individuals were seen growing where Eli's Paradise Meadow radiates into the adjacent Big Tree Forest. The individuals were growing in well developed soils with long-leaf pine litter in partial shade. This is the former site of Sunset Campground, which closed in the late 1960's.

\section{Swale Administrative Campground}

Centaurea solstitialis - Two plants observed. Both were collected.

Cirsium vulgare - Collected at Swale Campground along. the edges of a moist roadbed. The density of plants along the roadside averaged approximately $2-3$ plants per square meter. There is a patch in an adjacent meadow that is roughly $2 \mathrm{~m}$ by $5 \mathrm{~m}$.

Verbascum thapsus - Hundreds of plants grew in moist, disturbed places about the campground.

\section{Sycamore Creek}

Arundo donax - An early season survey revealed a single population approximately 50 meters upstream of Highway 198 growing from a flat, wet sand bar directly in the creek bed. On a return visit in August, three small colonies were observed in the same area. No other populations were encountered within the Sycamore Creek survey area. There was evidence that somebody had been actively eradicating this population; large piles of uprooted shoots were scattered throughout the area.

Carduus pycnocephalus - Thousands of these plants grew near the crossing of Shepherd Saddle Road on the stream bank and in the neighboring grassland, often choking out all other vegetation and attaining enormous size (up 
to $1.5 \mathrm{~m})$. Plants growing near the stream were bigger than plants in the adjacent grassland. Downstream of the crossing there were scattered plants in sunny areas but no colonies attained the size of the first.

Echinochloa crus-galli - This plant is very likely a species of Echinochloa, a late season, non-indigenous, annual grass. Fewer than ten plants were seen in Sycamore Creek growing in moist, well vegetated soil banks.

Marrubium vulgare - Fewer than 10 seedlings were observed on loose, sandy, well drained soils. Several mature plants were observed growing 10 meters west of the stream corridor along the Shepherd Saddle Road.

Melilotus indica - One small population of fewer than 100 individuals was observed on moist sand in deep shade. No other individuals were seen in the survey area.

Polypogon monspeliensis - Thousands of individuals were observed in small colonies throughout the survey area

Pyracantha angustifolia - One plant was found growing in the middle of the stream in a shady spot at the base of a mature Platanus occidentalis. This plant grew about 50 meters upstream of Buckeye Drive. This is the first collection for Sequoia-Kings Canyon National Parks.

Tamarix sp. - Two seedlings were observed in a sand bar in the middle of the stream in deep shade. The plants were less than 10 centimeters tall and appeared to be first-year seedlings. Due to the immaturity of the seedlings, it was impossible to determine the species of Tamarix that was seen. Other sightings of Tamarix this year have occurred during surveys in the Middle and North Forks of the Kaweah River. See collection ASP \#4350 PW for a voucher specimen from the North Fork.

\section{Trail for All People}

Dactylis glomerata - Thousands of individuals were seen scattered throughout the meadow edge, primarily on the west and north edges along the "Trail for All People". The plants radiate into the adjacent Big Tree Forest for several meters. Other populations of this species were observed at Eli's Paradise and along the asphalt road to Lower Kaweah on the west side of the Giant Forest Lodge.

Phleum pratense - Thousands of these plants grew around the margins of Round Meadow in partly shaded areas devoid of standing water.

\section{Traugers Creek}

Lathyrus latifolius - Thousands of individuals in large, dense colonies were observed at the junction of the Mineral King road and Traugers Creek. A large colony is directly along the Mineral King Road and extends approximately fifty meters upstream from the road.

Malus sylvestris - A mature, fruiting tree with several smaller trees nearby grew 20 meters upstream of the Mineral King Road. There were no other trees observed downstream of this population.

Poa pratensis - Fewer than 100 individuals were seen scattered throughout Trauger's creek in moist, shaded areas.

\section{Williams Meadow}

Poa pratensis - Tens of thousands of plants grew around the margins of this very expansive montane meadow.

\section{Wolverton Pack Station}

Tragopogon dubius - A single individual was found along the southern edge of the pack station complex in a mildly disturbed area. No other individuals were seen within the complex.

\section{Wolverton Snow Play Area}

Poa pratensis - Thousands of individuals growing in small populations were seen throughout the meadow in flat, wet, open areas with dense herbaceous layers and well developed, poorly drained soils. 


\section{Wuksachi}

Bromus tectorum - Thousands of individuals were growing in large colonies throughout the Wuksachi Complex in open, undisturbed and moderately disturbed sites.

Cirsium vulgare - A population of 12 individuals was observed adjacent to the northeast corner of the Wuksachi Fire House in open, moderately disturbed, well-developed soils.

Echinochloa crus-galli - A large population of greater than 1000 individuals was observed in a strip of loose disturbed, bare soil between an asphalt road and a concrete sidewalk. The strip of dirt had rice straw laid down upon it. The population was approximately $20 \mathrm{~m}$ by $2 \mathrm{~m}$. There was very little other vegetation growing there. No other populations were observed elsewhere in the survey area.

Melilotus alba - A single plant was seen growing 75 meters east of the Wuksachi Fire Station alongside an asphalt road.

Tragopogon dubius - Fewer than 100 individuals were seen scattered throughout the complex in open, partly disturbed areas with little herbaceous under story.

Verbascum thapsus - Three plants were seen on south side of the sewage treatment plant. Populations were observed scattered throughout the Wuksachi Complex.

Verbascum virgatum - Populations of this plant species grew in dry, exposed, roadside areas. One population was near the sewage treatment facility and one was alongside the entrance road to Wuksachi proper. These populations, numbering a few dozen plants each, contained first-year rosettes as well as blooming individuals. Fewer than 100 plants were observed two hundred meters southwest of the Wuksachi Fire Station in a flat, open area adjacent to the parking lot. The population was in decomposed granite and mulch laid down a previous year. Another population of fewer than twenty individuals was seen adjacent to the road leading to Wuksachi approximately one hundred meters north of the Generals Highway.

\section{Yucca Creek}

Carduus pycnocephalus - Fewer than 100 individuals were observed in small colonies scattered throughout the riparian zone in open, dry sand bars and rock cracks.

Ficus carica - This species has been noted in three different places in this area of Sequoia National Park. Two separate plants have been seen in the North Fork of the Kaweah River, upstream of Yucca Creek. The third and largest population grew in and along a lush, shady, rocky section of Yucca Creek about 100 meters upstream of the Kaweah River. There were a dozen or so individuals in this population, including one mature tree which had a trunk of 20 centimeters in diameter at 1.7 meters above the ground. The other members of this colony were but a few years old. Reproduction appeared to be of both sexual and vegetative nature. The entire colony occupied a space not bigger than 25 square meters. This is the first collection for Sequoia-Kings Canyon National Parks.

Juglans californica - These vegetative plants were likely a species of walnut native to the Great Valley and to western parts of California. What appeared to be one mother plant and ten or fifteen offspring grew along the north bank of Yucca Creek, about 350 meters upstream of the Old Hidden Springs Road crossing. The "mother" plant grew alongside the Old Hidden Springs Trail (residual planting?). The slope below it dropped into Yucca Creek. The several naturalized plants, ranging from about one to ten years old, were scattered upstream and downstream of the mature plant on the partly shaded, well-vegetated stream bank. What appeared to be Juglans regia (the walnut of commerce, not native to California) also grew nearby. These species are known to hybridize.

Juglans regia - Alongside the Old Hidden Springs Trail and about 350 meters upstream of the Old Hidden Springs Road crossing near a population of Juglans californica (see description above). Known to hybridize with $J$. californica.

Poa pratensis - Fewer than 1000 individuals were observed growing in scattered populations in partly shaded areas. 
Polypogon interruptus - Fewer than ten of these plants were seen in Yucca Creek in shaded, moist, rocky, streamside areas. This is the first collection for Sequoia-Kings Canyon National Parks.

Polypogon monspeliensis - Fewer than 100 individuals were seen scattered throughout the creek in open sand bars and rock cracks.

Rubus discolor - Thousands of individuals growing in numerous large colonies were observed in shaded places throughout the survey area.

Silybum marianum - Two populations of this plant were seen along Yucca Creek. One population was on an exposed, rocky, grassy flood plain, two kilometers upstream of the Kaweah River. The other population was on an exposed sandy bank $\backslash$ flood plain a few hundred meters downstream of the first. Each population contained a few dozen individuals and both were on the north side of Yucca Creek. This is the first collection for Sequoia-Kings Canyon National Parks.
Vitis vinifera - Frequent, dense patches of this plant are scattered throughout Yucca Creek. A native grape species, Vitis californica Benth. also occurs in the creek.

\section{Zumwalt Meadow Trail}

Bromus tectorum - We found fewer than 100 plants on the partly shaded, rocky, north bank of the Kings River 100 meters east of the trailhead parking lot.

Cirsium vulgare - We found fewer than 100 plants on the partly shaded, sandy, north bank of the Kings River 120 meters east of the trailhead parking lot.

Poa pratensis - We found fewer than 1000 plants on the partly shaded, sandy, north bank of the Kings River 120 meters east of the trailhead parking lot.

Verbascum thapsus - We found fewer than 100 plants on the partly shaded, rocky, north bank of the Kings River 100 meters east of the trailhead parking lot. 
Appendix D: Yosemite National Park alien plant species along roadsides.

\begin{tabular}{|c|c|c|}
\hline Road & Elevation (ft) & Alien Species \\
\hline Big Oak Flat Road & 4661 & Aira caryophyllea \\
\hline Big Oak Flat Road & 4661 & Avena fatua \\
\hline Big Oak Flat Road & 4661 & Bromus diandrus \\
\hline Big Oak Flat Road & 4661 & Bromus hordeaceus \\
\hline Big Oak Flat Road & 4661 & Bromus tectorum \\
\hline Big Oak Flat Road & 4661 & Chenopodium album \\
\hline Big Oak Flat Road & 4661 & Chenopodium botrys \\
\hline Big Oak Flat Road & 4661 & Cynosurus echinatus \\
\hline Big Oak Flat Road & 4661 & Holcus lanatus \\
\hline Big Oak Flat Road & 4661 & Hypericum perforatum \\
\hline Big Oak Flat Road & 4661 & Lactuca serriola \\
\hline Big Oak Flat Road & 4661 & Phleum pratense \\
\hline Big Oak Flat Road & 4661 & Poa bulbosa \\
\hline Big Oak Flat Road & 4661 & Polygonum arenastrum \\
\hline Big Oak Flat Road & 4661 & Sonchus oleraceus \\
\hline Big Oak Flat Road & 4661 & Vulpia myuros \\
\hline Big Oak Flat Road & 4946 & Avena barbata \\
\hline Big Oak Flat Road & 4946 & Bromus diandrus \\
\hline Big Oak Flat Road & 4946 & Bromus hordeaceus \\
\hline Big Oak Flat Road & 4946 & Bromus tectorum \\
\hline Big Oak Flat Road & 4946 & Cerastium glomeratum \\
\hline Big Oak Flat Road & 4946 & Cynosurus echinatus \\
\hline Big Oak Flat Road & 4946 & Dactylis glomerata \\
\hline Big Oak Flat Road & 4946 & Erodium cicutarium \\
\hline Big Oak Flat Road & 4946 & Hypericum perforatum \\
\hline Big Oak Flat Road & 4946 & Lactuca serriola \\
\hline Big Oak Flat Road & 4946 & Lathyrus latifolius \\
\hline Big Oak Flat Road & 4946 & Phleum pratense \\
\hline Big Oak Flat Road & 4946 & Plantago lanceolata \\
\hline Big Oak Flat Road & 4946 & Poa bulbosa \\
\hline Big Oak Flat Road & 4946 & Polygonum arenastrum \\
\hline Big Oak Flat Road & 4946 & Sisymbrium altissimum \\
\hline Big Oak Flat Road & 4946 & Sonchus asper \\
\hline Big Oak Flat Road & 4946 & Vulpia myuros \\
\hline Big Oak Flat Road & 5272 & Avena fatua \\
\hline Big Oak Flat Road & 5272 & Bromus diandrus \\
\hline Big Oak Flat Road & 5272 & Bromus hordeaceus \\
\hline Big Oak Flat Road & 5272 & Bromus tectorum \\
\hline Big Oak Flat Road & 5272 & Chenopodium album \\
\hline Big Oak Flat Road & 5272 & Chenopodium botrys \\
\hline Big Oak Flat Road & 5272 & Cynosums echinatus \\
\hline Big Oak Flat Road & 5272 & Herniaria hirsuta \\
\hline Big Oak Flat Road & 5272 & Holcus lanatus \\
\hline Big Oak Flat Road & 5272 & Lactuca serriola \\
\hline Big Oak Flat Road & 5272 & Plantago lanceolata \\
\hline Big Oak Flat Road & 5272 & Poa pratensis \\
\hline Big Oak Flat Road & 5272 & Polygonum arenastrum \\
\hline Big Oak Flat Road & 5272 & Rumex acetosella \\
\hline
\end{tabular}

\begin{tabular}{|c|c|c|}
\hline Alien Species & Elevation (ft) & Road \\
\hline Agrostis gigantea & 6040 & Wawona Road 3 \\
\hline Agrostis gigantea & 6051 & Wawona Road \\
\hline Aira caryophyllea & 3842 & El Portal Road \\
\hline Aira caryophyllea & 3964 & Wawona Road \\
\hline Aira caryophyllea & 4661 & Big Oak Flat Road \\
\hline Aira caryophyllea & 5505 & Hetch Hetchy Road \\
\hline Aira caryophyllea & 6040 & Wawona Road 3 \\
\hline Aira caryophyllea & 6051 & Wawona Road \\
\hline Amaranthus albus & 3959 & Northside Drive \\
\hline Anthemis cotula & 5969 & Yosemite West \\
\hline Avena barbata & 3964 & Wawona Road \\
\hline Avena barbata & 4946 & Big Oak Flat Road \\
\hline Avena barbata & 5505 & Hetch Hetchy Road \\
\hline Avena fatua & 4661 & Big Oak Flat Road \\
\hline Avena fatua & 5272 & Big Oak Flat Road \\
\hline Bromus arenarius & 3958 & Southside Drive \\
\hline Bromus diandrus & 3842 & El Portal Road \\
\hline Bromus diandrus & 3958 & Southside Drive \\
\hline Bromus diandrus & 3959 & Northside Drive \\
\hline Bromus diandrus & 3964 & Wawona Road \\
\hline Bromus diandrus & 4661 & Big Oak Flat Road \\
\hline Bromus diandrus & 4946 & Big Oak Flat Road \\
\hline Bromus diandrus & 5143 & Wawona Road 2 \\
\hline Bromus diandrus & 5272 & Big Oak Flat Road \\
\hline Bromus hordeaceus & 3842 & El Portal Road \\
\hline Bromus hordeaceus & 3958 & Southside Drive \\
\hline Bromus hordeaceus & 3959 & Northside Drive \\
\hline Bromus hordeaceus & 3964 & Wawona Road \\
\hline Bromus hordeaceus & 4661 & Big Oak Flat Road \\
\hline Bromus hordeaceus & 4946 & Big Oak Flat Road \\
\hline Bromus hordeaceus & 5272 & Big Oak Flat Road \\
\hline Bromus hordeaceus & 5505 & Hetch Hetchy Road \\
\hline Bromus inermis & 3842 & El Portal Road \\
\hline Bromus inermis & 5143 & Wawona Road 2 \\
\hline Bromus inermis & 5505 & Hetch Hetchy Road \\
\hline Bromus inermis & 6040 & Wawona Road 3 \\
\hline Bromus inermis & 7981 & Tioga Road \\
\hline Bromus secalinus & 3959 & Northside Drive \\
\hline Bromus secalinus & 3964 & Wawona Road \\
\hline Bromus sterilis & 3959 & Northside Drive \\
\hline Bromus tectortum & 3842 & El Portal Road \\
\hline Bromus tectorum & 3958 & Southside Drive \\
\hline Bromus tectorum & 3959 & Northside Drive \\
\hline Bromus tectortm & 3964 & Wawona Road \\
\hline Bromus tectorum & 4661 & Big Oak Flat Road \\
\hline Bromus tectorum & 4946 & Big Oak Flat Road \\
\hline Bromus tectonum & 5143 & Wawona Road 2 \\
\hline Bromus tectorum & 5272 & Big Oak Flat Road \\
\hline
\end{tabular}


Appendix D: (continued)

\begin{tabular}{|c|c|c|}
\hline Road & Elevation (ft) & Alien Species \\
\hline Big Oak Flat Road & 5272 & Sonchus asper \\
\hline Big Oak Flat Road & 5272 & Vulpia myuros \\
\hline Big Oak Flat Road & 5902 & Bromus tectorum \\
\hline Big Oak Flat Road & 5902 & Cirsium vulgare \\
\hline Big Oak Flat Road & 5902 & Herniaria hirsuta \\
\hline Big Oak Flat Road & 5902 & Lolium multiflonum \\
\hline Big Oak Flat Road & 5902 & Plantago lanceolata \\
\hline Big Oak Flat Road & 5902 & Polygonum arenastrum \\
\hline Big Oak Flat Road & 5902 & Rumex acetosella \\
\hline Big Oak Flat Road & 5902 & Spergularia rubra \\
\hline El Portal Road & 3842 & Aira caryophyllea \\
\hline El Portal Road & 3842 & Bromus diandrus \\
\hline El Portal Road & 3842 & Bromus hordeaceus \\
\hline El Portal Road & 3842 & Bromus inermis \\
\hline El Portal Road & 3842 & Bromus tectorum \\
\hline El Portal Road & 3842 & Chenopodium album \\
\hline El Portal Road & 3842 & Chenopodium botrys \\
\hline El Portal Road & 3842 & Cynosurus echinatus \\
\hline El Portal Road & 3842 & Galium parisiense \\
\hline El Portal Road & 3842 & Herniaria hirsuta \\
\hline El Portal Road & 3842 & Hordeum murinum \\
\hline El Portal Road & 3842 & Lactuca serriola \\
\hline El Portal Road & 3842 & Plantago lanceolata \\
\hline El Portal Road & 3842 & Poa bulbosa \\
\hline El Portal Road & 3842 & Poa pratensis \\
\hline El Portal Road & 3842 & Polygonum arenastrum \\
\hline El Portal Road & 3842 & Trifolium hirtum \\
\hline El Portal Road & 3842 & Vulpia myuros \\
\hline Glacier Point Road & 6179 & Rumex acetosella \\
\hline Glacier Point Road & 6440 & Cirsium vulgare \\
\hline Glacier Point Road & 6440 & Plantago lanceolata \\
\hline Glacier Point Road & 6440 & Plantago major \\
\hline Glacier Point Road & 6440 & Rumex acetosella \\
\hline Glacier Point Road & 7176 & Spergularia rubra \\
\hline Glacier Point Road & 7704 & Spergularia mibra \\
\hline Hetch Hetchy Road & 5505 & Aira caryophyllea \\
\hline Hetch Hetchy Road & 5505 & Avena barbata \\
\hline Hetch Hetchy Road & 5505 & Bromus hordeaceus \\
\hline Hetch Hetchy Road & 5505 & Bromus inermis \\
\hline Hetch Hetchy Road & 5505 & Bromus tectorum \\
\hline Hetch Hetchy Road & 5505 & Hypericum perforatum \\
\hline Hetch Hetchy Road & 5505 & Rumex acetosella \\
\hline Hetch Hetchy Road & 5505 & Spergularia rubra \\
\hline Hetch Hetchy Road & 5505 & Vulpia myuros \\
\hline Northside Drive & 3959 & Amaranthus albus \\
\hline Northside Drive & 3959 & Bromus diandrus \\
\hline Northside Drive & 3959 & Bromus hordeaceus \\
\hline Northside Drive & 3959 & Bromus secalinus \\
\hline Northside Drive & 3959 & Bromus sterilis \\
\hline
\end{tabular}

\begin{tabular}{|c|c|c|}
\hline Alien Species & Elevation (ft) & Road \\
\hline Bromus tectorum & 5505 & Hetch Hetchy Road \\
\hline Bromus tectorum & 5902 & Big Oak Flat Road \\
\hline Bromus tectorum & 5969 & Yosemite West \\
\hline Bromus tectorum & 6040 & Wawona Road 3 \\
\hline Bromus tectorum & 6051 & Wawona Road \\
\hline Bromus tectorum & 8472 & Tioga Road \\
\hline Centaurea solstitialis & 5143 & Wawona Road 2 \\
\hline Cerastium glomeratum & 4946 & Big Oak Flat Road \\
\hline Cerastium glomeratum & 5969 & Yosemite West \\
\hline Chamomilla suaveolens & 3958 & Southside Drive \\
\hline Chamomilla suaveolens & 3959 & Northside Drive \\
\hline Chamomilla suaveolens & 3964 & Wawona Road \\
\hline Chenopodium album & 3842 & El Portal Road \\
\hline Chenopodium album & 3958 & Southside Drive \\
\hline Chenopodium album & 3959 & Northside Drive \\
\hline Chenopodium album & 4661 & Big Oak Flat Road \\
\hline Chenopodium album & 5143 & Wawona Road 2 \\
\hline Chenopodium album & 5272 & Big Oak Flat Road \\
\hline Chenopodium album & 5969 & Yosemite West \\
\hline Chenopodium album & 6051 & Wawona Road \\
\hline Chenopodium botrys & 3842 & El Portal Road \\
\hline Chenopodium botrys & 3958 & Southside Drive \\
\hline Chenopodium botrys & 3959 & Northside Drive \\
\hline Chenopodium botrys & 4661 & Big Oak Flat Road \\
\hline Chenopodium botrys & 5143 & Wawona Road 2 \\
\hline Chenopodium botrys & 5272 & Big Oak Flat Road \\
\hline Chenopodium botrys & 5969 & Yosemite West \\
\hline Chenopodium botrys & 6051 & Wawona Road \\
\hline Cirsium vulgare & 3958 & Southside Drive \\
\hline Cirsium vulgare & 5143 & Wawona Road 2 \\
\hline Cirsium vulgare & 5902 & Big Oak Flat Road \\
\hline Cirsium vulgare & 5969 & Yosemite West \\
\hline Cirsium vulgare & 6040 & Wawona Road 3 \\
\hline Cirsium vulgare & 6051 & Wawona Road \\
\hline Cirsium vulgare & 6254 & Tioga Road \\
\hline Cirsinm vulgare & 6440 & Glacier Point Road \\
\hline Cynosurus echinatus & 3842 & El Portal Road \\
\hline Cynosurus echinatus & 3958 & Southside Drive \\
\hline Cynosurus echinatus & 3959 & Northside Drive \\
\hline Cynosurus echinatus & 3964 & Wawona Road \\
\hline Cynosurus echinatus & 4661 & Big Oak Flat Road \\
\hline Cynosurus echinatus & 4946 & Big Oak Flat Road \\
\hline Cynosurus echinatus & 5272 & Big Oak Flat Road \\
\hline Dactylis glomerata & 3958 & Southside Drive \\
\hline Dactylis glomerata & 3959 & Northside Drive \\
\hline Dactylis glomerata & 4946 & Big Oak Flat Road \\
\hline Dactylis glomerata & 6254 & Tioga Road \\
\hline Erodium cicutarium & 4946 & Big Oak Flat Road \\
\hline Galium parisiense & 3842 & El Portal Road \\
\hline
\end{tabular}


Appendix D: (continued)

\begin{tabular}{|c|c|c|c|c|c|}
\hline Road & Elevation (ft) & Alien Species & Alien Species & Elevation $(\mathrm{ft})$ & Road \\
\hline Northside Drive & 3959 & Bromus tectorum & Galium parisiense & 3958 & Southside Drive \\
\hline Northside Drive & 3959 & Chamomilla suaveolens & Herniaria hirsuta & 3842 & El Portal Road \\
\hline Northside Drive & 3959 & Chenopodium album & Herniaria hirsuta & 3959 & Northside Drive \\
\hline Northside Drive & 3959 & Chenopodium botrys & Herniaria hirsuta & 5272 & Big Oak Flat Road \\
\hline Northside Drive & 3959 & Cynosurus echinatus & Herniaria hirsuta & 5902 & Big Oak Flat Road \\
\hline Northside Drive & 3959 & Dactylis glomerata & Herniaria hirsuta & 8472 & Tioga Road \\
\hline Northside Drive & 3959 & Herniaria hirsuta & Holcus lanatus & 3964 & Wawona Road \\
\hline Northside Drive & 3959 & Hordeum murinum & Holcus lanatus & 4661 & Big Oak Flat Road \\
\hline Northside Drive & 3959 & Hypericum perforatum & Holcus lanatus & 5272 & Big Oak Flat Road \\
\hline Northside Drive & 3959 & Lactuca serriola & Holcus lanatus & 6051 & Wawona Road \\
\hline Northside Drive & 3959 & Lolium perenne & Hordeum murinum & 3842 & El Portal Road \\
\hline Northside Drive & 3959 & Plantago lanceolata & Hordeum murinum & 3958 & Southside Drive \\
\hline Northside Drive & 3959 & Poa annua & Hordeum murinum & 3959 & Northside Drive \\
\hline Northside Drive & 3959 & Poa bulbosa & Hypericum perforatum & 3959 & Northside Drive \\
\hline Northside Drive & 3959 & Poa pratensis & Hypericum perforatum & 3964 & Wawona Road \\
\hline Northside Drive & 3959 & Polygonum arenastrum & Hypericum perforatum & 4661 & Big Oak Flat Road \\
\hline Northside Drive & 3959 & Polygonum convolvulus & Hypericum perforatum & 4946 & Big Oak Flat Road \\
\hline Northside Drive & 3959 & Rumex acetosella & Hypericum perforatum & 5505 & Hetch Hetchy Road \\
\hline Northside Drive & 3959 & Rumex crispus & Hypochaeris radicata & 3958 & Southside Drive \\
\hline Northside Drive & 3959 & Sisymbrium altissimum & Lactuca serriola & 3842 & El Portal Road \\
\hline Northside Drive & 3959 & Sonchus asper & Lactuca serriola & 3958 & Southside Drive \\
\hline Northside Drive & 3959 & Spergularia rubra & Lactuca serriola & 3959 & Northside Drive \\
\hline Northside Drive & 3959 & Taraxacum officinale & Lactuca serriola & 3964 & Wawona Road \\
\hline Northside Drive & 3959 & Tragopogon dubius & Lactuca serriola & 4661 & Big Oak Flat Road \\
\hline Northside Drive & 3959 & Trifolium repens & Lactuca serriola & 4946 & Big Oak Flat Road \\
\hline Northside Drive & 3959 & Vulpia myuros & Lactuca serriola & 5143 & Wawona Road 2 \\
\hline Southside Drive & 3958 & Bromus arenarius & Lactuca serriola & 5272 & Big Oak Flat Road \\
\hline Southside Drive & 3958 & Bromus diandrus & Lactuca serriola & 5969 & Yosemite West \\
\hline Southside Drive & 3958 & Bromus hordeaceus & Lactuca serriola & 6040 & Wawona Road 3 \\
\hline Southside Drive & 3958 & Bromus tectorum & Lactuca serriola & 6051 & Wawona Road \\
\hline Southside Drive & 3958 & Chamomilla suaveolens & Lathyrus latifolius & 4946 & Big Oak Flat Road \\
\hline Southside Drive & 3958 & Chenopodium album & Lolium multiflorum & 5902 & Big Oak Flat Road \\
\hline Southside Drive & 3958 & Chenopodium botrys & Lolium multiflorum & 5969 & Yosemite West \\
\hline Southside Drive & 3958 & Cirsium vulgare & Lolium perenne & 3958 & Southside Drive \\
\hline Southside Drive & 3958 & Cynosurus echinatus & Lolium perenne & 3959 & Northside Drive \\
\hline Southside Drive & 3958 & Dactylis glomerata & Lolium perenne & 5969 & Yosemite West \\
\hline Southside Drive & 3958 & Galium parisiense & Phleum pratense & 4661 & Big Oak Flat Road \\
\hline Southside Drive & 3958 & Hordeum murinum & Phleum pratense & 4946 & Big Oak Flat Road \\
\hline Southside Drive & 3958 & Hypochaeris radicata & Plantago lanceolata & 3842 & El Portal Road \\
\hline Southside Drive & 3958 & Lactuca serriola & Plantago lanceolata & 3958 & Southside Drive \\
\hline Southside Drive & 3958 & Lolium perenne & Plantago lanceolata & 3959 & Northside Drive \\
\hline Southside Drive & 3958 & Plantago lanceolata & Plantago lanceolata & 3964 & Wawona Road \\
\hline Southside Drive & 3958 & Poa bulbosa & Plantago lanceolata & 4946 & Big Oak Flat Road \\
\hline Southside Drive & 3958 & Poa pratensis & Plantago lanceolata & 5143 & Wawona Road 2 \\
\hline Southside Drive & 3958 & Polygonum arenastrum & Plantago lanceolata & 5272 & Big Oak Flat Road \\
\hline Southside Drive & 3958 & Rumex acetosella & Plantago lanceolata & 5902 & Big Oak Flat Road \\
\hline Southside Drive & 3958 & Silene latifolia & Plantago lanceolata & 5969 & Yosemite West \\
\hline Southside Drive & 3958 & Sisymbrium altissimum & Plantago lanceolata & 6040 & Wawona Road 3 \\
\hline Southside Drive & 3958 & Taraxacum officinale & Plantago lanceolata & 6051 & Wawona Road \\
\hline
\end{tabular}


Appendix D: (continued)

\begin{tabular}{|c|c|c|}
\hline Road & Elevation (ft) & Alien Species \\
\hline Southside Drive & 3958 & Tragopogon dubius \\
\hline Southside Drive & 3958 & Trifolium repens \\
\hline Southside Drive & 3958 & Verbascum thapsus \\
\hline Tioga Road & 6254 & Cirsium vulgare \\
\hline Tioga Road & 6254 & Dactylis glomerata \\
\hline Tioga Road & 6254 & Plantago lanceolata \\
\hline Tioga Road & 6254 & Poa annua \\
\hline Tioga Road & 6254 & Polygonum arenastrum \\
\hline Tioga Road & 6254 & Polygonum arenastrum \\
\hline Tioga Road & 6254 & Rumex acetosella \\
\hline Tioga Road & 7143 & Rumex acetosella \\
\hline Tioga Road & 7143 & Spergularia rubra \\
\hline Tioga Road & 7981 & Bromus inermis \\
\hline Tioga Road & 7981 & Spergularia rubra \\
\hline Tioga Road & 8127 & Rumex acetosella \\
\hline Tioga Road & 8127 & Spergularia rubra \\
\hline Tioga Road & 8150 & Rumex acetosella \\
\hline Tioga Road & 8150 & Spergularia rubra \\
\hline Tioga Road & 8472 & Bromus tectorum \\
\hline Tioga Road & 8472 & Herniaria hirsuta \\
\hline Tioga Road & 8472 & Rumex acetosella \\
\hline Tioga Road & 8472 & Spergularia rubra \\
\hline Tioga Road & 8674 & Spergularia rubra \\
\hline Wawona Road & 3964 & Aira caryophyllea \\
\hline Wawona Road & 3964 & Avena barbata \\
\hline Wawona Road & 3964 & Bromus diandrus \\
\hline Wawona Road & 3964 & Bromus hordeaceus \\
\hline Wawona Road & 3964 & Bromus secalinus \\
\hline Wawona Road & 3964 & Bromus tectorum \\
\hline Wawona Road & 3964 & Chamomilla suaveolens \\
\hline Wawona Road & 3964 & Cynosurus echinatus \\
\hline Wawona Road & 3964 & Holcus lanatus \\
\hline Wawona Road & 3964 & Hypericum perforatum \\
\hline Wawona Road & 3964 & Lactuca serriola \\
\hline Wawona Road & 3964 & Plantago lanceolata \\
\hline Wawona Road & 3964 & Poa bulbosa \\
\hline Wawona Road & 3964 & Poa pratensis \\
\hline Wawona Road & 3964 & Polvgonum arenastrum \\
\hline Wawona Road & 3964 & Rumex acetosella \\
\hline Wawona Road & 3964 & Sonchus asper \\
\hline Wawona Road & 3964 & Spergularia mbra \\
\hline Wawona Road & 3964 & Vulpia myuros \\
\hline Wawona Road & 6051 & Agrostis gigantea \\
\hline Wawona Road & 6051 & Aira caryophyllea \\
\hline Wawona Road & 6051 & Bromus tectorum \\
\hline Wawona Road & 6051 & Chenopodium album \\
\hline Wawona Road & 6051 & Chenopodium botrys \\
\hline Wawona Road & 6051 & Cirsium vulgare \\
\hline Wawona Road & 6051 & Holcus lanatus \\
\hline
\end{tabular}

\begin{tabular}{|c|c|c|}
\hline Alien Species & Elevation (ft) & Road \\
\hline Plantago lanceolata & 6254 & Tioga Road \\
\hline Plantago lanceolata & 6440 & Glacier Point Road \\
\hline Plantago major & 6051 & Wawona Road \\
\hline Plantago major & 6440 & Glacier Point Road \\
\hline Poa annua & 3959 & Northside Drive \\
\hline Poa annua & 5143 & Wawona Road 2 \\
\hline Poa annua & 6040 & Wawona Road 3 \\
\hline Poa annua & 6051 & Wawona Road \\
\hline Poa annua & 6254 & Tioga Road \\
\hline Poa bulbosa & 3842 & El Portal Road \\
\hline Poa bulbosa & 3958 & Southside Drive \\
\hline Poa bulbosa & 3959 & Northside Drive \\
\hline Poa bulbosa & 3964 & Wawona Road \\
\hline Poa bulbosa & 4661 & Big Oak Flat Road \\
\hline Poa bulbosa & 4946 & Big Oak Flat Road \\
\hline Poa pratensis & 3842 & El Portal Road \\
\hline Poa pratensis & 3958 & Southside Drive \\
\hline Poa pratensis & 3959 & Northside Drive \\
\hline Poa pratensis & 3964 & Wawona Road \\
\hline Poa pratensis & 5143 & Wawona Road 2 \\
\hline Poa pratensis & 5272 & Big Oak Flat Road \\
\hline Poa pratensis & 5969 & Yosemite West \\
\hline Poa pratensis & 6040 & Wawona Road 3 \\
\hline Poa pratensis & 6051 & Wawona Road \\
\hline Polygonum arenastrum & 3842 & El Portal Road \\
\hline Polygonum arenastrum & 3958 & Southside Drive \\
\hline Polygonum arenastrum & 3959 & Northside Drive \\
\hline Polygonum arenastrum & 3964 & Wawona Road \\
\hline Polygonum arenastrum & 4661 & Big Oak Flat Road \\
\hline Polygonum arenastrum & 4946 & Big Oak Flat Road \\
\hline Polygonum arenastrum & 5143 & Wawona Road 2 \\
\hline Polygonum arenastrum & 5272 & Big Oak Flat Road \\
\hline Polygonum arenastrum & 5902 & Big Oak Flat Road \\
\hline Polygonum arenastrum & 5969 & Yosemite West \\
\hline Polygonum arenastrum & 6051 & Wawona Road \\
\hline Polygonum arenastrum & 6254 & Tioga Road \\
\hline Polygonum arenastrum & 6254 & Tioga Road \\
\hline Polygonum convolvulus & 3959 & Northside Drive \\
\hline Raphanus raphanistrum & 5969 & Yosemite West \\
\hline Raphanus sativus & 5969 & Yosemite West \\
\hline Rumex acetosella & 3958 & Southside Drive \\
\hline Rumex acetosella & 3959 & Northside Drive \\
\hline Rumex acetosella & 3964 & Wawona Road \\
\hline Rumex acetosella & 5143 & Wawona Road 2 \\
\hline Rumex acetosella & 5272 & Big Oak Flat Road \\
\hline Rumex acetosella & 5505 & Hetch Hetchy Road \\
\hline Rumex acetosella & 5902 & Big Oak Flat Road \\
\hline Rumex acetosella & 5969 & Yosemite West \\
\hline Rumex acetosella & 6040 & Wawona Road 3 \\
\hline
\end{tabular}


Appendix D: (continued)

\begin{tabular}{|c|c|c|}
\hline Road & Elevation (ft) & Alien Species \\
\hline Wawona Road & 6051 & Lactuca serriola \\
\hline Wawona Road & 6051 & Plantago lanceolata \\
\hline Wawona Road & 6051 & Plantago major \\
\hline Wawona Road & 6051 & Poa annua \\
\hline Wawona Road & 6051 & Poa pratensis \\
\hline Wawona Road & 6051 & Polygonum arenastrum \\
\hline Wawona Road & 6051 & Rumex acetosella \\
\hline Wawona Road & 6051 & Spergularia rubra \\
\hline Wawona Road & 6051 & Trifolium repens \\
\hline Wawona Road 2 & 5143 & Bromus diandrus \\
\hline Wawona Road 2 & 5143 & Bromus inermis \\
\hline Wawona Road 2 & 5143 & Bromus tectorum \\
\hline Wawona Road 2 & 5143 & Centaurea solstitialis \\
\hline Wawona Road 2 & 5143 & Chenopodium album \\
\hline Wawona Road 2 & 5143 & Chenopodium botrys \\
\hline Wawona Road 2 & 5143 & Cirsium vulgare \\
\hline Wawona Road 2 & 5143 & Lactuca serriola \\
\hline Wawona Road 2 & 5143 & Plantago lanceolata \\
\hline Wawona Road 2 & 5143 & Poa annua \\
\hline Wawona Road 2 & 5143 & Poa pratensis \\
\hline Wawona Road 2 & 5143 & Polygonum arenastrum \\
\hline Wawona Road 2 & 5143 & Rumex acetosella \\
\hline Wawona Road 2 & 5143 & Silene latifolia \\
\hline Wawona Road 2 & 5143 & Vulpia myuros \\
\hline Wawona Road 3 & 6040 & Agrostis gigantea \\
\hline Wawona Road 3 & 6040 & Aira caryophyllea \\
\hline Wawona Road 3 & 6040 & Bromus inermis \\
\hline Wawona Road 3 & 6040 & Bromus tectorum \\
\hline Wawona Road 3 & 6040 & Cirsium vulgare \\
\hline Wawona Road 3 & 6040 & Lactuca serriola \\
\hline Wawona Road 3 & 6040 & Plantago lanceolata \\
\hline Wawona Road 3 & 6040 & Poa annua \\
\hline Wawona Road 3 & 6040 & Poa pratensis \\
\hline Wawona Road 3 & 6040 & Rumex acetosella \\
\hline Wawona Road 3 & 6040 & Silene latifolia \\
\hline Wawona Road 3 & 6040 & Tragopogon dubius \\
\hline Wawona Road 3 & 6040 & Vulpia myuros \\
\hline Yosemite West & 5969 & Anthemis cotula \\
\hline Yosemite West & 5969 & Bromus tectorum \\
\hline Yosemite West & 5969 & Cerastium glomeratum \\
\hline Yosemite West & 5969 & Chenopodium album \\
\hline Yosemite West & 5969 & Chenopodium botrys \\
\hline Yosemite West & 5969 & Cirsium vulgare \\
\hline Yosemite West & 5969 & Lactuca serriola \\
\hline Yosemite West & 5969 & Lolium multiflonum \\
\hline Yosemite West & 5969 & Lolium perenne \\
\hline Yosemite West & 5969 & Plantago lanceolata \\
\hline Yosemite West & 5969 & Poa pratensis \\
\hline Yosemite West & 5969 & Polygonum arenastrum \\
\hline
\end{tabular}

\begin{tabular}{|c|c|c|}
\hline Alien Species & Elevation (ft) & Road \\
\hline Rumex acetosella & 6051 & Wawona Road \\
\hline Rumex acetosella & 6179 & Glacier Point Road \\
\hline Rumex acetosella & 6254 & Tioga Road \\
\hline Rumex acetosella & 6440 & Glacier Point Road \\
\hline Rumex acetosella & 7143 & Tioga Road \\
\hline Rumex acetosella & 8127 & Tioga Road \\
\hline Rumex acetosella & 8150 & Tioga Road \\
\hline Rumex acetosella & 8472 & Tioga Road \\
\hline Rumex crispus & 3959 & Northside Drive \\
\hline Silene latifolia & 3958 & Southside Drive \\
\hline Silene latifolia & 5143 & Wawona Road 2 \\
\hline Silene latifolia & 6040 & Wawona Road 3 \\
\hline Sinapis arvensis & 5969 & Yosemite West \\
\hline Sisymbrium altissimum & 3958 & Southside Drive \\
\hline Sisymbrium altissimum & 3959 & Northside Drive \\
\hline Sisymbrium altissimum & 4946 & Big Oak Flat Road \\
\hline Sonchus asper & 3959 & Northside Drive \\
\hline Sonchus asper & 3964 & Wawona Road \\
\hline Sonchus asper & 4946 & Big Oak Flat Road \\
\hline Sonchus asper & 5272 & Big Oak Flat Road \\
\hline Sonchus oleraceus & 4661 & Big Oak Flat Road \\
\hline Spergularia rubra & 3959 & Northside Drive \\
\hline Spergularia rubra & 3964 & Wawona Road \\
\hline Spergularia rubra & 5505 & Hetch Hetchy Road \\
\hline Spergularia rubra & 5902 & Big Oak Flat Road \\
\hline Spergularia rubra & 5969 & Yosemite West \\
\hline Spergularia rubra & 6051 & Wawona Road \\
\hline Spergularia nibra & 7143 & Tioga Road \\
\hline Spergularia rubra & 7176 & Glacier Point Road \\
\hline Spergularia rubra & 7704 & Glacier Point Road \\
\hline Spergularia rubra & 7981 & Tioga Road \\
\hline Spergularia rubra & 8127 & Tioga Road \\
\hline Spergularia rubra & 8150 & Tioga Road \\
\hline Spergularia rubra & 8472 & Tioga Road \\
\hline Spergularia rubra & 8674 & Tioga Road \\
\hline Taraxacum officinale & 3958 & Southside Drive \\
\hline Taraxacum officinale & 3959 & Northside Drive \\
\hline Tragopogon dubius & 3958 & Southside Drive \\
\hline Tragopogon dubius & 3959 & Northside Drive \\
\hline Tragopogon dubius & 6040 & Wawona Road 3 \\
\hline Trifolium hirtum & 3842 & El Portal Road \\
\hline Trifolium repens & 3958 & Southside Drive \\
\hline Trifolium repens & 3959 & Northside Drive \\
\hline Trifolium repens & 5969 & Yosemite West \\
\hline Trifolium repens & 6051 & Wawona Road \\
\hline Triticum aestivum & 5969 & Yosemite West \\
\hline Verbascum thapsus & 3958 & Southside Drive \\
\hline Verbascum thapsus & 5969 & Yosemite West \\
\hline Vulpia myuros & 3842 & El Portal Road \\
\hline
\end{tabular}


Appendix D: (continued)

\begin{tabular}{|l|cl|}
\hline \multicolumn{1}{|c|}{ Road } & Elevation (ft) & \multicolumn{1}{c|}{ Alien Species } \\
\hline Yosemite West & 5969 & Raphanus raphanistrum \\
Yosemite West & 5969 & Raphanus sativus \\
Yosemite West & 5969 & Rumex acetosella \\
Yosemite West & 5969 & Sinapis arvensis \\
Yosemite West & 5969 & Spergularia rubra \\
Yosemite West & 5969 & Trifolium repens \\
Yosemite West & 5969 & Triticum aestivum \\
Yosemite West & 5969 & Verbascum thapsus \\
Yosemite West & 5969 & Vulpia myuros \\
\hline
\end{tabular}

\begin{tabular}{|c|c|c|}
\hline \multicolumn{3}{|c|}{ Species Richness Summary - by Road Section } \\
\hline & & Alien \\
\hline Road & Elevation (ft) & Species Richness \\
\hline Big Oak Flat Road & 4661 & 16 \\
\hline Big Oak Flat Road & 4946 & 18 \\
\hline Big Oak Flat Road & 5272 & 16 \\
\hline Big Oak Flat Road & 5902 & 8 \\
\hline Glacier Point Road & 6179 & 1 \\
\hline Glacier Point Road & 6440 & 4 \\
\hline Glacier Point Road & 7176 & 1 \\
\hline Glacier Point Road & 7704 & 1 \\
\hline Hetch Hetchy Road & 5505 & 9 \\
\hline El Portal Road & 3842 & 18 \\
\hline Northside Drive & 3959 & 31 \\
\hline Southside Drive & 3958 & 26 \\
\hline Tioga Road & 6254 & 7 \\
\hline Tioga Road & 7143 & 2 \\
\hline Tioga Road & 7981 & 2 \\
\hline Tioga Road & 8127 & 2 \\
\hline Tioga Road & 8150 & 2 \\
\hline Tioga Road & 8472 & 4 \\
\hline Tioga Road & 8674 & 1 \\
\hline Wawona Road & 3964 & 19 \\
\hline Wawona Road & 5142 & 15 \\
\hline Wawona Road & 6040 & 14 \\
\hline Wawona Road & 6051 & 16 \\
\hline Yosemite West & 5969 & 22 \\
\hline Total Roadside Species & & Total $=57$ \\
\hline
\end{tabular}

\begin{tabular}{|l|cl|}
\hline \multicolumn{1}{|c|}{ Alien Species } & Elevation (ft) & \multicolumn{1}{c|}{ Road } \\
\hline Vulpia myuros & 3959 & Northside Drive \\
Vulpia myuros & 3964 & Wawona Road \\
Vulpia myuros & 4661 & Big Oak Flat Road \\
Vulpia myuros & 4946 & Big Oak Flat Road \\
Vulpia myuros & 5143 & Wawona Road 2 \\
Vulpia myuros & 5272 & Big Oak Flat Road \\
Vulpia myuros & 5505 & Hetch Hetchy Road \\
Vulpia myuros & 5969 & Yosemite West \\
Vulpia myuros & 6040 & Wawona Road 3 \\
\hline
\end{tabular}

\begin{tabular}{|c|c|c|}
\hline \\
\hline \multicolumn{3}{|c|}{$\begin{array}{l}\text { Species Richness Summary - by Richness levels } \\
\text { Alien }\end{array}$} \\
\hline Road & Elevation (ft) & Species Richness \\
\hline Northside Drive & 3959 & 31 \\
\hline Southside Drive & 3958 & 26 \\
\hline Yosemite West & 5969 & 22 \\
\hline Wawona Road & 3964 & 19 \\
\hline El Portal Road & 3842 & 18 \\
\hline Big Oak Flat Road & 4946 & 18 \\
\hline Big Oak Flat Road & 4661 & 16 \\
\hline Big Oak Flat Road & 5272 & 16 \\
\hline Wawona Road & 6051 & 16 \\
\hline Wawona Road & 5142 & 15 \\
\hline Wawona Road & 6040 & 14 \\
\hline Hetch Hetchy Road & 5505 & 9 \\
\hline Big Oak Flat Road & 5902 & 8 \\
\hline Tioga Road & 6254 & 7 \\
\hline Glacier Point Road & 6440 & 4 \\
\hline Tioga Road & 8472 & 4 \\
\hline Tioga Road & 7143 & 2 \\
\hline Tioga Road & 7981 & 2 \\
\hline Tioga Road & 8127 & 2 \\
\hline Tioga Road & 8150 & 2 \\
\hline Glacier Point Road & 6179 & 1 \\
\hline Glacier Point Road & 7176 & 1 \\
\hline Glacier Point Road & 7704 & 1 \\
\hline Tioga Road & 8674 & 1 \\
\hline $\begin{array}{l}\text { Total Roadside } \\
\text { Species }\end{array}$ & & Total $=57$ \\
\hline
\end{tabular}


Appendix E. Yosemite National Park alien plant species along trails.

\begin{tabular}{|c|c|c|}
\hline Trail & Elevation $(\mathrm{ft})$ & Alien Species \\
\hline Alder Creek & 4557 & Aira caryophyllea \\
\hline Alder Creek & 4557 & Bromus tectorum \\
\hline Alder Creek & 4557 & Holcus lanatus \\
\hline Alder Creek & 4557 & Hypericum perforatum \\
\hline Alder Creek & 4557 & Poa pratensis \\
\hline Alder Creek & 4557 & Rumex acetosella \\
\hline Alder Creek & 4557 & Vulpia myuros \\
\hline Bridalveil Creek & 6969 & Poa annua \\
\hline Bridalveil Creek & 6969 & Poa pratensis \\
\hline Bridalveil Falls & 4035 & Bromus hordeaceus \\
\hline Bridalveil Falls & 4035 & Bromus tectorum \\
\hline Bridalveil Falls & 4035 & Poa bulbosa \\
\hline Bridalveil Falls & 4035 & Poa pratensis \\
\hline Bridalveil Falls & 4035 & Silene latifolia \\
\hline Bridalveil Falls & 4035 & Stellaria media \\
\hline Bridalveil Falls & 4035 & Vulpia myuros \\
\hline Bridalveil-Inspiration Pt. & 4036 & Aira caryophyllea \\
\hline Bridalveil-Inspiration Pt. & 4036 & Bromus tectorum \\
\hline Bridalveil-Inspiration Pt. & 4036 & Cirsium vulgare \\
\hline Bridalveil-Inspiration Pt. & 4036 & Holcus lanatus \\
\hline Bridalveil-Inspiration Pt. & 4036 & Sonchus asper \\
\hline Bridalveil-Inspiration Pt. & 4036 & Vulpia myuros \\
\hline Chilnualna Falls & 4417 & Aira caryophyllea \\
\hline Chilnualna Falls & 4417 & Bromus tectorum \\
\hline Chilnualna Falls & 4417 & Holcus lanatus \\
\hline Chilnualna Falls & 4417 & Poa compressa \\
\hline Chilnualna Falls & 4417 & Sonchus asper \\
\hline Chilnualna Falls & 4417 & Vulpia myuros \\
\hline Four Mile & 3960 & Bromus tectorum \\
\hline Four Mile & 3960 & Chenopodium botrys \\
\hline Four Mile & 3960 & Erodium cicutarium \\
\hline Four Mile & 3960 & Holcus lanatus \\
\hline Four Mile & 3960 & Poa annua \\
\hline Four Mile & 3960 & Poa bulbosa \\
\hline Four Mile & 3960 & Poa pratensis \\
\hline Four Mile & 3960 & Rumex acetosella \\
\hline Four Mile & 3960 & Silene latifolia \\
\hline Four Mile & 3960 & Taraxacum officinale \\
\hline Four Mile & 3960 & Vulpia myuros \\
\hline Glen Aulin & 8686 & Poa pratensis \\
\hline Glen Aulin & 8686 & Spergularia mibra \\
\hline Glen Aulin & 8686 & Trifolium repens \\
\hline Happy Isles & 4959 & Agrowis gigantea \\
\hline Happy Isles & 4959 & Bar a vulgaris \\
\hline Happy Isles & 4959 & Bromus inermis \\
\hline Happy Isles & 4959 & Bromus tectorum \\
\hline Happy Isles & 4959 & Cerastium glomeratum \\
\hline Happy Isles & 4959 & Cirsium vulgare \\
\hline
\end{tabular}

\begin{tabular}{|c|c|c|}
\hline Alien Species & Elevation (ft) & Trail \\
\hline Agrostis gigantea & 3972 & Yosemite Loop \\
\hline Agrostis gigantea & 4053 & Meadow Loop \\
\hline Agrostis gigantea & 4100 & Snow Creek \\
\hline Agrostis gigantea & 4770 & Old Big Oak Flat Rd. \\
\hline Agrostis gigantea & 4959 & Happy Isles \\
\hline Aira caryophyllea & 4036 & Bridalveil-Inspiration Pt. \\
\hline Aira caryophyllea & 4053 & Meadow Loop \\
\hline Aira caryophyllea & 4100 & Snow Creek \\
\hline Aira caryophyllea & 4417 & Chilnualna Falls \\
\hline Aira caryophyllea & 4557 & Alder Creek \\
\hline Aira caryophyllea & 4770 & Old Big Oak Flat Rd. \\
\hline Aira caryophyllea & 5256 & Mariposa Grove \\
\hline Avena barbata & 4100 & Snow Creek \\
\hline Barbarea vulgaris & 4959 & Happy Isles \\
\hline Bromus arenarius & 5256 & Mariposa Grove \\
\hline Bromus diandrus & 3931 & Mirror Lake Pack \\
\hline Bromus diandrus & 3972 & Yosemite Loop \\
\hline Bromus diandrus & 4053 & Meadow Loop \\
\hline Bromus diandrus & 4100 & Snow Creek \\
\hline Bromus hordeaceus & 3972 & Yosemite Loop \\
\hline Bromus hordeaceus & 4035 & Bridalveil Falls \\
\hline Bromus hordeaceus & 4053 & Meadow Loop \\
\hline Bromus inermis & 4053 & Meadow Loop \\
\hline Bromus inermis & 4959 & Happy Isles \\
\hline Bromus inermis & 7243 & Panorama \\
\hline Bromus sterilis & 4015 & Yosemite Falls \\
\hline Bromus sterilis & 4100 & Snow Creek \\
\hline Bromus sterilis & 4770 & Old Big Oak Flat Rd. \\
\hline Bromus tectorum & 3931 & Mirror Lake Pack \\
\hline Bromus tectorum & 3960 & Four Mile \\
\hline Bromus tectorum & 3972 & Yosemite Loop \\
\hline Bromus tectorum & 4015 & Yosemite Falls \\
\hline Bromus tectorum & 4035 & Bridalveil Falls \\
\hline Bromus tectorum & 4036 & Bridalveil-Inspiration Pt. \\
\hline Bromus tectorum & 4053 & Meadow Loop \\
\hline Bromus tectorum & 4100 & Snow Creek \\
\hline Bromus tectorum & 4381 & Inspiration Pt. \\
\hline Bromus tectorum & 4417 & Chilnualna Falls \\
\hline Bromus tectorum & 4557 & Alder Creek \\
\hline Bromus tectonum & 4770 & Old Big Oak Flat Rd. \\
\hline Bromus tectonum & 4959 & Happy Isles \\
\hline Bromus tectorum & 5256 & Mariposa Grove \\
\hline Bromus tectorum & 7243 & Panorama \\
\hline Capsella bursa-pastoris & 8622 & Young Lake \\
\hline Cerastium glomeratum & 4053 & Meadow Loop \\
\hline Cerastium glomeratum & 4100 & Snow Creek \\
\hline Cerastium glomeratum & 4959 & Happy Isles \\
\hline Cerastium glomeratum & 6339 & Tamarack Creek \\
\hline
\end{tabular}


Appendix E. (continued)

\begin{tabular}{|c|c|c|c|c|c|}
\hline Trail & \begin{tabular}{|l|} 
Elevation (ft) \\
\end{tabular} & Alien Species & Alien Species & \begin{tabular}{|l|} 
Elevation (ft) \\
\end{tabular} & Trail \\
\hline Happy Isles & 4959 & Galium parisiense & Chenopodium album & 3972 & Yosemite Loop \\
\hline Happy Isles & 4959 & Holcus lanatus & Chenopodium album & 4381 & Inspiration Pt. \\
\hline Happy Isles & 4959 & Lolium multiflorum & Chenopodium botrys & 3960 & Four Mile \\
\hline Happy Isles & 4959 & Poa pratensis & Cirsium vulgare & 3931 & Mirror Lake Pack \\
\hline Happy Isles & 4959 & Sisymbrium altissimum & Cirsium vulgare & 3972 & Yosemite Loop \\
\hline Happy Isles & 4959 & Vulpia myuros & Cirsium vulgare & 4036 & Bridalveil-Inspiration Pt. \\
\hline Harden Lake & 7821 & Poa annua & Cirsium vulgare & 4053 & Meadow Loop \\
\hline Harden Lake & 7821 & Rumex acetosella & Cirsium vulgare & 4770 & Old Big Oak Flat Rd. \\
\hline Harden Lake & 7821 & Spergularia rubra & Cirsium vulgare & 4959 & Happy Isles \\
\hline Harden Lake & 7821 & Taraxacum officinale & Cirsium vulgare & 5256 & Mariposa Grove \\
\hline Inspiration Pt. & 4381 & Bromus tectorum & Cirsium vulgare & 7243 & Panorama \\
\hline Inspiration Pt. & 4381 & Chenopodium album & Cynosurus echinatus & 3972 & Yosemite Loop \\
\hline Inspiration Pt. & 4381 & Poa annua & Cynosurus echinatus & 4053 & Meadow Loop \\
\hline Inspiration Pt. & 4381 & Silene latifolia & Dactylis glomerata & 4771 & Merced Grove \\
\hline John Muir-Tuolumne & 8675 & Spergularia rubra & Erodium cicutarium & 3960 & Four Mile \\
\hline John Muir-Tuolumne & 8675 & Taraxacum officinale & Erodium cicutarium & 4053 & Meadow Loop \\
\hline Lukens Lake & 7886 & Spergularia rubra & Festuca pratensis & 5256 & Mariposa Grove \\
\hline Lukens Lake & 7886 & Taraxacum officinale & Galium parisiense & 3972 & Yosemite Loop \\
\hline Mariposa Grove & 5256 & Aira caryophyllea & Galium parisiense & 4015 & Yosemite Falls \\
\hline Mariposa Grove & 5256 & Bromus arenarius & Galium parisiense & 4053 & Meadow Loop \\
\hline Mariposa Grove & 5256 & Bromus tectorum & Galium parisiense & 4959 & Happy Isles \\
\hline Mariposa Grove & 5256 & Cirsium vulgare & Galium parisiense & 5256 & Mariposa Grove \\
\hline Mariposa Grove & 5256 & Festuca pratensis & Herniaria hirsuta & 4053 & Meadow Loop \\
\hline Mariposa Grove & 5256 & Galium parisiense & Holcus lanatus & 3931 & Mirror Lake Pack \\
\hline Mariposa Grove & 5256 & Holcus lanatus & Holcus lanatus & 3960 & Four Mile \\
\hline Mariposa Grove & 5256 & Lactuca serriola & Holcus lanatus & 3972 & Yosemite Loop \\
\hline Mariposa Grove & 5256 & Poa annua & Holcus lanatus & 4015 & Yosemite Falls \\
\hline Mariposa Grove & 5256 & Poa pratensis & Holcus lanatus & 4036 & Bridalveil-Inspiration Pt. \\
\hline Mariposa Grove & 5256 & Silene latifolia & Holcus lanatus & 4053 & Meadow Loop \\
\hline Mariposa Grove & 5256 & Taraxacum officinale & Holcus lanatus & 4417 & Chilnualna Falls \\
\hline Mariposa Grove & 5256 & Vulpia myuros & Holcus lanatus & 4557 & Alder Creek \\
\hline Meadow Loop & 4053 & Agrostis gigantea & Holcus lanatus & 4770 & Old Big Oak Flat Rd. \\
\hline Meadow Loop & 4053 & Aira caryophyllea & Holcus lanatus & 4959 & Happy Isles \\
\hline Meadow Loop & 4053 & Bromus diandrus & Holcus lanatus & 5256 & Mariposa Grove \\
\hline Meadow Loop & 4053 & Bromus hordeaceus & Hordeum murinum & 3931 & Mirror Lake Pack \\
\hline Meadow Loop & 4053 & Bromus inermis & Hordeum murinum & 3972 & Yosemite Loop \\
\hline Meadow Loop & 4053 & Bromus tectorum & Hypericum perforatum & 4015 & Yosemite Falls \\
\hline Meadow Loop & 4053 & Cerastium glomeratum & Hypericum perforatum & 4557 & Alder Creek \\
\hline Meadow Loop & 4053 & Cirsium vulgare & Lactuca serriola & 3931 & Mirror Lake Pack \\
\hline Meadow Loop & 4053 & Cynosurus echinatus & Lactuca serriola & 3972 & Yosemite Loop \\
\hline Meadow Loop & 4053 & Erodium cicutarium & Lactuca serriola & 4015 & Yosemite Falls \\
\hline Meadow Loop & 4053 & Galium parisiense & Lactuca serriola & 4770 & Old Big Oak Flat Rd. \\
\hline Meadow Loop & 4053 & Herniaria hirsuta & Lactuca serriola & 5256 & Mariposa Grove \\
\hline Meadow Loop & 4053 & Holcus lanatus & Lathyrus latifolius & 4053 & Meadow Loop \\
\hline Meadow Loop & 4053 & Lathyrus latifolius & Lolium multiflorum & 4959 & Happy Isles \\
\hline Meadow Loop & 4053 & Phleum pratense & Phleum pratense & 3931 & Mirror Lake Pack \\
\hline Meadow Loop & 4053 & Plantago lanceolata & Phleum pratense & 3972 & Yosemite Loop \\
\hline Meadow Loop & 4053 & Plantago major & Phleum pratense & 4053 & Meadow Loop \\
\hline Meadow Loop & 4053 & Poa bulbosa & Plantago lanceolata & 3931 & Mirror Lake Pack \\
\hline
\end{tabular}


Appendix E. (continued)

\begin{tabular}{|c|c|c|}
\hline Trail & Elevation (ft) & Alien Species \\
\hline Meadow Loop & 4053 & Poa pratensis \\
\hline Meadow Loop & 4053 & Polygonum arenastrum \\
\hline Meadow Loop & 4053 & Rubus discolor \\
\hline Meadow Loop & 4053 & Rubus laciniatus \\
\hline Meadow Loop & 4053 & Rumex acetosella \\
\hline Meadow Loop & 4053 & Sisymbrium altissimum \\
\hline Meadow Loop & 4053 & Sonchus asper \\
\hline Meadow Loop & 4053 & Sonchus oleraceus \\
\hline Meadow Loop & 4053 & Stellaria media \\
\hline Meadow Loop & 4053 & Taraxacum officinale \\
\hline Meadow Loop & 4053 & Tragopogon dubius \\
\hline Meadow Loop & 4053 & Trifolium repens \\
\hline Meadow Loop & 4053 & Verbascum thapsus \\
\hline Meadow Loop & 4053 & Vulpia myuros \\
\hline Merced Grove & 4771 & Dactylis glomerata \\
\hline Merced Grove & 4771 & Rumex acetosella \\
\hline Mirror Lake Pack & 3931 & Bromus diandrus \\
\hline Mirror Lake Pack & 3931 & Bromus tectorum \\
\hline Mirror Lake Pack & 3931 & Cirsium vulgare \\
\hline Mirror Lake Pack & 3931 & Holcus lanatus \\
\hline Mirror Lake Pack & 3931 & Hordeum murinum \\
\hline Mirror Lake Pack & 3931 & Lactuca serriola \\
\hline Mirror Lake Pack & 3931 & Phleum pratense \\
\hline Mirror Lake Pack & 3931 & Plantago lanceolata \\
\hline Mirror Lake Pack & 3931 & Poa annua \\
\hline Mirror Lake Pack & 3931 & Poa pratensis \\
\hline Mirror Lake Pack & 3931 & Polygonum arenastrum \\
\hline Mirror Lake Pack & 3931 & Rubus discolor \\
\hline Mirror Lake Pack & 3931 & Trifolium repens \\
\hline Mirror Lake Pack & 3931 & Vulpia myuros \\
\hline Old Big Oak Flat Rd. & 4770 & Agrostis gigantea \\
\hline Old Big Oak Flat Rd. & 4770 & Aira caryophyllea \\
\hline Old Big Oak Flat Rd. & 4770 & Bromus sterilis \\
\hline Old Big Oak Flat Rd. & 4770 & Bromus tectorum \\
\hline Old Big Oak Flat Rd. & 4770 & Cirsium vulgare \\
\hline Old Big Oak Flat Rd. & 4770 & Holcus lanatus \\
\hline Old Big Oak Flat Rd. & 4770 & Lactuca serriola \\
\hline Old Big Oak Flat Rd. & 4770 & Tragopogon dubius \\
\hline Old Big Oak Flat Rd. & 4770 & Vulpia myuros \\
\hline Panorama & 7243 & Bromus inermis \\
\hline Panorama & 7243 & Bromus tectonum \\
\hline Panorama & 7243 & Cirsium vulgare \\
\hline Panorama & 7243 & Spergularia nubra \\
\hline Porcupine Creek & 8100 & Rumex acetosella \\
\hline Snow Creek & 4100 & Agrostis gigantea \\
\hline Snow Creek & 4100 & Aira caryophyllea \\
\hline Snow Creek & 4100 & Avena barbata \\
\hline Snow Creek & 4100 & Bromus diandrus \\
\hline Snow Creek & 4100 & Bromus sterilis \\
\hline
\end{tabular}

\begin{tabular}{|c|c|c|}
\hline Alien Species & Elevation (ft) & Trail \\
\hline Plantago lanceolata & 4053 & Meadow Loop \\
\hline Plantago major & 4053 & Meadow Loop \\
\hline Poa annua & 3931 & Mirror Lake Pack \\
\hline Poa annua & 3960 & Four Mile \\
\hline Poa annua & 3972 & Yosemite Loop \\
\hline Poa annua & 4381 & Inspiration $\mathrm{Pt}$. \\
\hline Poa annua & 5256 & Mariposa Grove \\
\hline Poa annua & 6969 & Bridalveil Creek \\
\hline Poa annua & 7729 & Taft Point \\
\hline Poa annua & 7821 & Harden Lake \\
\hline Poa bulbosa & 3960 & Four Mile \\
\hline Poa bulbosa & 3972 & Yosemite Loop \\
\hline Poa bulbosa & 4035 & Bridalveil Falls \\
\hline Poa bulbosa & 4053 & Meadow Loop \\
\hline Poa compressa & 4417 & Chilnualna Falls \\
\hline Poa pratensis & 3931 & Mirror Lake Pack \\
\hline Poa pratensis & 3960 & Four Mile \\
\hline Poa pratensis & 3972 & Yosemite Loop \\
\hline Poa pratensis & 4035 & Bridalveil Falls \\
\hline Poa pratensis & 4053 & Meadow Loop \\
\hline Poa pratensis & 4100 & Snow Creek \\
\hline Poa pratensis & 4557 & Alder Creek \\
\hline Poa pratensis & 4959 & Happy Isles \\
\hline Poa pratensis & 5256 & Mariposa Grove \\
\hline Poa pratensis & 6969 & Bridalveil Creek \\
\hline Poa pratensis & 8622 & Young Lake \\
\hline Poa pratensis & 8686 & Glen Aulin \\
\hline Polygonum arenastrum & 3931 & Mirror Lake Pack \\
\hline Polygonum arenastrum & 3972 & Yosemite Loop \\
\hline Polygonum arenastrum & 4053 & Meadow Loop \\
\hline Rubus discolor & 3931 & Mirror Lake Pack \\
\hline Rubus discolor & 3972 & Yosemite Loop \\
\hline Rubus discolor & 4053 & Meadow Loop \\
\hline Rubus laciniatus & 4053 & Meadow Loop \\
\hline Rumex acetosella & 3960 & Four Mile \\
\hline Rumex acetosella & 3972 & Yosemite Loop \\
\hline Rumex acetosella & 4053 & Meadow Loop \\
\hline Rumex acetosella & 4557 & Alder Creek \\
\hline Rumex acetosella & 4771 & Merced Grove \\
\hline Rumex acetosella & 6339 & Tamarack Creek \\
\hline Rumex acetosella & 7821 & Harden Lake \\
\hline Rumex acetosella & 8100 & Porcupine Creek \\
\hline Rumex crispus & 3972 & Yosemite Loop \\
\hline Silene latifolia & 3960 & Four Mile \\
\hline Silene latifolia & 4035 & Bridalveil Falls \\
\hline Silene latifolia & 4381 & Inspiration Pt. \\
\hline Silene latifolia & 5256 & Mariposa Grove \\
\hline Sisymbrium altissimum & 4053 & Meadow Loop \\
\hline Sisymbrium altissimum & 4959 & Happy Isles \\
\hline
\end{tabular}


Appendix E. (continued)

\begin{tabular}{|c|c|c|c|c|c|}
\hline Trail & Elevation (ft) & Alien Species & Alien Species & Elevation (ft) & Trail \\
\hline Snow Creek & 4100 & Bromus tectorum & Sonchus asper & 3972 & Yosemite Loop \\
\hline Snow Creek & 4100 & Cerastium glomeratum & Sonchus asper & 4036 & Bridalveil-Inspiration Pt. \\
\hline Snow Creek & 4100 & Poa pratensis & Sonchus asper & 4053 & Meadow Loop \\
\hline Snow Creek & 4100 & Vulpia myuros & Sonchus asper & 4417 & Chilnualna Falls \\
\hline Taft Point & 7729 & Poa anntia & Sonchus oleraceus & 4015 & Yosemite Falls \\
\hline Tamarack Creek & 6339 & Cerastium glomeratum & Sonchus oleraceus & 4053 & Meadow Loop \\
\hline Tamarack Creek & 6339 & Rumex acetosella & Spergularia nubra & 3972 & Yosemite Loop \\
\hline Tamarack Creek & 6339 & Spergularia rubra & Spergularia rubra & 6339 & Tamarack Creek \\
\hline Yosemite Falls & 4015 & Bromus sterilis & Spergularia rubra & 7243 & Panorama \\
\hline Yosemite Falls & 4015 & Bromus tectorum & Spergularia rubra & 7821 & Harden Lake \\
\hline Yosemite Falls & 4015 & Galium parisiense & Spergularia rubra & 7886 & Lukens Lake \\
\hline Yosemite Falls & 4015 & Holcus lanatus & Spergularia rubra & 8675 & John Muir-Tuolumne \\
\hline Yosemite Falls & 4015 & Hypericum perforatum & Spergularia rubra & 8686 & Glen Aulin \\
\hline Yosemite Falls & 4015 & Lactuca serriola & Stellaria media & 4035 & Bridalveil Falls \\
\hline Yosemite Falls & 4015 & Sonchus oleraceus & Stellaria media & 4053 & Meadow Loop \\
\hline Yosemite Falls & 4015 & Vulpia myuros & Taraxacum officinale & 3960 & Four Mile \\
\hline Yosemite Loop & 3972 & Agrostis gigantea & Taraxacum officinale & 3972 & Yosemite Loop \\
\hline Yosemite Loop & 3972 & Bromus diandrus & Taraxacum officinale & 4053 & Meadow Loop \\
\hline Yosemite Loop & 3972 & Bromus hordeaceus & Taraxacum officinale & 5256 & Mariposa Grove \\
\hline Yosemite Loop & 3972 & Bromus tectorum & Taraxacum officinale & 7821 & Harden Lake \\
\hline Yosemite Loop & 3972 & Chenopodium album & Taraxacum officinale & 7886 & Lukens Lake \\
\hline Yosemite Loop & 3972 & Cirsium vulgare & Taraxacum officinale & 8675 & John Muir-Tuolumne \\
\hline Yosemite Loop & 3972 & Cynosurus echinatus & Torilis arvensis & 3972 & Yosemite Loop \\
\hline Yosemite Loop & 3972 & Galium parisiense & Tragopogon dubius & 3972 & Yosemite Loop \\
\hline Yosemite Loop & 3972 & Holcus lanatus & Tragopogon dubius & 4053 & Meadow Loop \\
\hline Yosemite Loop & 3972 & Hordeum murinum & Tragopogon dubius & 4770 & Old Big Oak Flat Rd. \\
\hline Yosemite Loop & 3972 & Lactuca serriola & Trifolium repens & 3931 & Mirror Lake Pack \\
\hline Yosemite Loop & 3972 & Phleum pratense & Trifolium repens & 4053 & Meadow Loop \\
\hline Yosemite Loop & 3972 & Poa annua & Trifolium repens & 8686 & Glen Aulin \\
\hline Yosemite Loop & 3972 & Poa bulbosa & Verbascum thapsus & 3972 & Yosemite Loop \\
\hline Yosemite Loop & 3972 & Poa pratensis & Verbascum thapsus & 4053 & Meadow Loop \\
\hline Yosemite Loop & 3972 & Polygonum arenastrum & Vulpia myuros & 3931 & Mirror Lake Pack \\
\hline Yosemite Loop & 3972 & Rubus discolor & Vulpia myuros & 3960 & Four Mile \\
\hline Yosemite Loop & 3972 & Rumex acetosella & Vulpia myuros & 3972 & Yosemite Loop \\
\hline Yosemite Loop & 3972 & Rumex crispus & Vulpia myuros & 4015 & Yosemite Falls \\
\hline Yosemite Loop & 3972 & Sonchus asper & Vulpia myuros & 4035 & Bridalveil Falls \\
\hline Yosemite Loop & 3972 & Spergularia rubra & Vulpia myuros & 4036 & Bridalveil-Inspiration Pt. \\
\hline Yosemite Loop & 3972 & Taraxacum officinale & Vulpia myuros & 4053 & Meadow Loop \\
\hline Yosemite Loop & 3972 & Torilis arvensis & Vulpia myuros & 4100 & Snow Creek \\
\hline Yosemite Loop & 3972 & Tragopogon dubius & Vulpia myuros & 4417 & Chilnualna Falls \\
\hline Yosemite Loop & 3972 & Verbascum thapsus & Vulpia myuros & 4557 & Alder Creek \\
\hline Yosemite Loop & 3972 & Vulpia myuros & Vulpia myuros & 4770 & Old Big Oak Flat Rd. \\
\hline Young Lakes & 8622 & Capsella bursa-pastoris & Vulpia myuros & 4959 & Happy Isles \\
\hline Young Lakes & 8622 & Poa pratensis & Vulpia myuros & 5256 & Mariposa Grove \\
\hline
\end{tabular}


Appendix E. (continued)

\begin{tabular}{|c|c|c|}
\hline \multicolumn{2}{|c|}{ Trail Species Richness Summary - by Trail } & \multirow{3}{*}{$\begin{array}{c}\text { Alien } \\
\text { Species Richness }\end{array}$} \\
\hline & & \\
\hline Trail & Elevation (ft) & \\
\hline Alder Creek & 4557 & 7 \\
\hline Bridalveil Creek & 6969 & 2 \\
\hline Bridalveil Falls & 4035 & 7 \\
\hline Bridalveil-Inspiration Pt. & 4036 & 6 \\
\hline Chilnualna Falls & 4417 & 6 \\
\hline Four Mile & 3960 & 11 \\
\hline Glen Aulin & 8686 & 3 \\
\hline Happy Isles & 4959 & 12 \\
\hline Harden Lake & 7821 & 4 \\
\hline Inspiration Pt. & 4381 & 4 \\
\hline John Muir-Tuolumne & 8675 & 2 \\
\hline Lukens Lake & 7886 & 2 \\
\hline Meadow Loop & 4053 & 32 \\
\hline Merced Grove & 4771 & 2 \\
\hline Mirror Lake Pack & 3931 & 14 \\
\hline Old Big Oak Flat Rd. & 4770 & 9 \\
\hline Panorama & 7243 & 4 \\
\hline Porcupine Creek & 8100 & 1 \\
\hline Snow Creek & 4100 & 9 \\
\hline Taft Point & 7729 & 1 \\
\hline Tamarack Creek & 6339 & 3 \\
\hline Mariposa Grove & 5256 & 13 \\
\hline Yosemite Falls & 4015 & 8 \\
\hline Yosemite Loop & 3972 & 26 \\
\hline Young Lakes & 8622 & 2 \\
\hline Trailside Species & & Total $=\mathbf{5 1}$ \\
\hline
\end{tabular}

\begin{tabular}{|c|c|c|}
\hline \multicolumn{3}{|c|}{ Trail Species Richness Summary - by Richness Levels } \\
\hline & & Alien \\
\hline Trail & Elevation $(\mathrm{ft})$ & Species Richness \\
\hline Meadow Loop & 4053 & 32 \\
\hline Yosemite Loop & 3972 & 26 \\
\hline Mirror Lake Pack & 3931 & 14 \\
\hline Mariposa Grove & 5256 & 13 \\
\hline Happy Isles & 4959 & 12 \\
\hline Four Mile & 3960 & 11 \\
\hline Old Big Oak Flat Rd. & 4770 & 9 \\
\hline Snow Creek & 4100 & 9 \\
\hline Yosemite Falls & 4015 & 8 \\
\hline Alder Creek & 4557 & 7 \\
\hline Bridalveil Falls & 4035 & 7 \\
\hline Bridalveil-Inspiration Pt. & 4036 & 6 \\
\hline Chilnualna Falls & 4417 & 6 \\
\hline Inspiration Pt. & 4381 & 4 \\
\hline Harden Lake & 7821 & 4 \\
\hline Panorama & 7243 & 4 \\
\hline Glen Aulin & 8686 & 3 \\
\hline Tamarack Creek & 6339 & 3 \\
\hline Bridalveil Creek & 6969 & 2 \\
\hline John Muir-Tuolumne & 8675 & 2 \\
\hline Lukens Lake & 7886 & 2 \\
\hline Merced Grove & 4771 & 2 \\
\hline Young Lakes & 8622 & 2 \\
\hline Porcupine Creek & 8100 & 1 \\
\hline Taft Point & 7729 & 1 \\
\hline Trailside Species & & Total $=51$ \\
\hline
\end{tabular}


Appendix F. Yosemite National Park alien plant species in and around corrals and stables.

\begin{tabular}{|c|c|c|}
\hline Site & Elevation (ft) & Alien Species \\
\hline Concession Stables (YV) & 4000 & Agrostis gigantea \\
\hline Concession Stables (YV) & 4000 & Bromus diandrus \\
\hline Concession Stables (YV) & 4000 & Bromus inermis \\
\hline Concession Stables (YV) & 4000 & Bromus secalinus \\
\hline Concession Stables (YV) & 4000 & Bromus tectorum \\
\hline Concession Stables (YV) & 4000 & Cerastium glomeratum \\
\hline Concession Stables (YV) & 4000 & Cirsium vulgare \\
\hline Concession Stables (YV) & 4000 & Dactylis glomerata \\
\hline Concession Stables (YV) & 4000 & Dianthus barbatus \\
\hline Concession Stables (YV) & 4000 & Holcus lanatus \\
\hline Concession Stables (YV) & 4000 & Hordeum murinum \\
\hline Concession Stables (YV) & 4000 & Hypericum perforatum \\
\hline Concession Stables (YV) & 4000 & Lactuca serriola \\
\hline Concession Stables (YV) & 4000 & Leucanthemum vulgare \\
\hline Concession Stables (YV) & 4000 & Lolium perenne \\
\hline Concession Stables (YV) & 4000 & Lychnis coronaria \\
\hline Concession Stables (YV) & 4000 & Phleum pratense \\
\hline Concession Stables (YV) & 4000 & Plantago lanceolata \\
\hline Concession Stables (YV) & 4000 & Poa annua \\
\hline Concession Stables (YV) & 4000 & Poa bulbosa \\
\hline Concession Stables (YV) & 4000 & Poa pratensis \\
\hline Concession Stables (YV) & 4000 & Polygonum arenastrum \\
\hline Concession Stables (YV) & 4000 & Rubus discolor \\
\hline Concession Stables (YV) & 4000 & Rumex acetosella \\
\hline Concession Stables (YV) & 4000 & Rumex crispus \\
\hline Concession Stables (YV) & 4000 & Silene latifolia \\
\hline Concession Stables (YV) & 4000 & Sonchus oleraceus \\
\hline Concession Stables (YV) & 4000 & Stellaria media \\
\hline Concession Stables (YV) & 4000 & Taraxacum officinale \\
\hline Concession Stables (YV) & 4000 & Tragopogon dubius \\
\hline Concession Stables (YV) & 4000 & Trifolium repens \\
\hline Concession Stables (YV) & 4000 & Verbascum thapsus \\
\hline Concession Stables (YV) & 4000 & Vulpia myuros \\
\hline Glen Aulin High Sierra Camp & 7832 & Taraxacum officinale \\
\hline Glen Aulin High Sierra Camp & 7832 & Trifolium repens \\
\hline Government Corrals (Tuol) & 8695 & Bromus catharticus \\
\hline Government Corrals (Tuol) & 8695 & Poa pratensis \\
\hline Government Stables (YV) & 4039 & Bromus diandrus \\
\hline Government Stables (YV) & 4039 & Bromus sterilis \\
\hline Government Stables (YV) & 4039 & Bromus tectorum \\
\hline Government Stables (YV) & 4039 & Capsella bursa-pastoris \\
\hline Government Stables (YV) & 4039 & Chenopodium botrys \\
\hline Government Stables (YV) & 4039 & Erodium cicutarium \\
\hline Government Stables (YV) & 4039 & Hordeum murinum \\
\hline Government Stables (YV) & 4039 & Lolium multiflonum \\
\hline Government Stables (YV) & 4039 & Poa bulbosa \\
\hline Government Stables (YV) & 4039 & Sisymbrium altissimum \\
\hline Government Stables (YV) & 4039 & Stellaria media \\
\hline
\end{tabular}

\begin{tabular}{|c|c|c|}
\hline Alien Species & Elevation (ft) & Site \\
\hline Agrostis gigantea & 4000 & Concession Stables (YV) \\
\hline Aira caryophyllea & 3960 & Hetch Hetchy Corral \\
\hline Aira caryophyllea & 4001 & Wawona Stables \\
\hline Aira caryophyllea & 4093 & McCauley Ranch \\
\hline Avena barbata & 3960 & Hetch Hetchy Corral \\
\hline Bromus catharticus & 8695 & Government Corrals (Tuol) \\
\hline Bromus diandrus & 3960 & Hetch Hetchy Corral \\
\hline Bromus diandrus & 4000 & Concession Stables (YV) \\
\hline Bromus diandrus & 4001 & Wawona Stables \\
\hline Bromus diandrus & 4039 & Government Stables (YV) \\
\hline Bromus diandrus & 4093 & McCauley Ranch \\
\hline Bromus hordeaceus & 3960 & Hetch Hetchy Corral \\
\hline Bromus hordeaceus & 4001 & Wawona Stables \\
\hline Bromus hordeaceus & 4093 & McCauley Ranch \\
\hline Bromus inermis & 4000 & Concession Stables (YV) \\
\hline Bromus inermis & 4093 & McCauley Ranch \\
\hline Bromus secalinus & 4000 & Concession Stables (YV) \\
\hline Bromus sterilis & 3960 & Hetch Hetchy Corral \\
\hline Bromus sterilis & 4039 & Government Stables (YV) \\
\hline Bromus tectorum & 3960 & Hetch Hetchy Corral \\
\hline Bromus tectorum & 4000 & Concession Stables (YV) \\
\hline Bromus tectorum & 4001 & Wawona Stables \\
\hline Bromus tectorum & 4039 & Government Stables (YV) \\
\hline Bromus tectorum & 4093 & McCauley Ranch \\
\hline Capsella bursa-pastoris & 3960 & Hetch Hetchy Corral \\
\hline Capsella bursa-pastoris & 4039 & Government Stables (YV) \\
\hline Capsella bursa-pastoris & 7496 & Harden Lake Corral \\
\hline Capsella bursa-pastoris & 7967 & White Wolf Corral \\
\hline Centaurea solstitialis & 3960 & Hetch Hetchy Corral \\
\hline Centaurea solstitialis & 4093 & McCauley Ranch \\
\hline Cerastium glomeratum & 3960 & Hetch Hetchy Corral \\
\hline Cerastium glomeratum & 4000 & Concession Stables (YV) \\
\hline Chamomilla suaveolens & 3960 & Hetch Hetchy Corral \\
\hline Chamomilla suaveolens & 4001 & Wawona Stables \\
\hline Chamomilla suaveolens & 7967 & White Wolf Corral \\
\hline Chenopodium botrys & 3960 & Hetch Hetchy Corral \\
\hline Chenopodium botrys & 4039 & Government Stables (YV) \\
\hline Cirsium vulgare & 4000 & Concession Stables (YV) \\
\hline Cirsium vulgare & 4093 & McCauley Ranch \\
\hline Convolvulus arvensis & 4093 & McCauley Ranch \\
\hline Cynodon dactylon & 4093 & McCauley Ranch \\
\hline Cynosurus echinatus & 3960 & Hetch Hetchy Corral \\
\hline Cynosurus echinatus & 4001 & Wawona Stables \\
\hline Cynosurus echinatus & 4093 & McCauley Ranch \\
\hline Dactylis glomerata & 4000 & Concession Stables (YV) \\
\hline Dactylis glomerata & 8632 & Tuolumne Stables \\
\hline Dianthus barbatus & 4000 & Concession Stables (YV) \\
\hline Erodium cicutaritum & 3960 & Hetch Hetchy Corral \\
\hline
\end{tabular}


Appendix F. (continued)

\begin{tabular}{|c|c|c|}
\hline Site & Elevation (ft) & Alien Species \\
\hline Government Stables (YV) & 4039 & Urtica urens \\
\hline Government Stables (YV) & 4039 & Vulpia myuros \\
\hline Harden Lake Corral & 7496 & Capsella bursa-pastoris \\
\hline Harden Lake Corral & 7496 & Herniaria hirsuta \\
\hline Harden Lake Corral & 7496 & Poa annua \\
\hline Harden Lake Corral & 7496 & Poa pratensis \\
\hline Harden Lake Corral & 7496 & Rumex acetosella \\
\hline Harden Lake Corral & 7496 & Spergularia rubra \\
\hline Harden Lake Corral & 7496 & Trifolium repens \\
\hline Harden Lake Corral & 7496 & Veronica persica \\
\hline Hetch Hetchy Corral & 3960 & Aira caryophyllea \\
\hline Hetch Hetchy Corral & 3960 & Avena barbata \\
\hline Hetch Hetchy Corral & 3960 & Bromus diandrus \\
\hline Hetch Hetchy Corral & 3960 & Bromus hordeaceus \\
\hline Hetch Hetchy Corral & 3960 & Bromus sterilis \\
\hline Hetch Hetchy Corral & 3960 & Bromus tectorum \\
\hline Hetch Hetchy Corral & 3960 & Capsella bursa-pastoris \\
\hline Hetch Hetchy Corral & 3960 & Centaurea solstitialis \\
\hline Hetch Hetchy Corral & 3960 & Cerastium glomeratum \\
\hline Hetch Hetchy Corral & 3960 & Chamomilla suaveolens \\
\hline Hetch Hetchy Corral & 3960 & Chenopodium botrys \\
\hline Hetch Hetchy Corral & 3960 & Cynosurus echinatus \\
\hline Hetch Hetchy Corral & 3960 & Erodium cicutarium \\
\hline Hetch Hetchy Corral & 3960 & Filago gallica \\
\hline Hetch Hetchy Corral & 3960 & Galium parisiense \\
\hline Hetch Hetchy Corral & 3960 & Herniaria hirsuta \\
\hline Hetch Hetchy Corral & 3960 & Hordeum murinum \\
\hline Hetch Hetchy Corral & 3960 & Lactuca serriola \\
\hline Hetch Hetchy Corral & 3960 & Malva parviflora \\
\hline Hetch Hetchy Corral & 3960 & Parapholis incurva \\
\hline Hetch Hetchy Corral & 3960 & Poa annua \\
\hline Hetch Hetchy Corral & 3960 & Poa bulbosa \\
\hline Hetch Hetchy Corral & 3960 & Poa pratensis \\
\hline Hetch Hetchy Corral & 3960 & Polygonum arenastrum \\
\hline Hetch Hetchy Corral & 3960 & Polypogon maritimus \\
\hline Hetch Hetchy Corral & 3960 & Rumex acetosella \\
\hline Hetch Hetchy Corral & 3960 & Rumex crispus \\
\hline Hetch Hetchy Corral & 3960 & Sonchus oleraceus \\
\hline Hetch Hetchy Corral & 3960 & Stellaria media \\
\hline Hetch Hetchy Corral & 3960 & Torilis arvensis \\
\hline Hetch Hetchy Corral & 3960 & Vulpia myuros \\
\hline McCauley Ranch & 4093 & Aira caryophyllea \\
\hline McCauley Ranch & 4093 & Bromus diandrus \\
\hline McCauley Ranch & 4093 & Bromus hordeaceus \\
\hline McCauley Ranch & 4093 & Bromus inermis \\
\hline McCauley Ranch & 4093 & Bromus tectorum \\
\hline McCauley Ranch & 4093 & Centaurea solstitialis \\
\hline McCauley Ranch & 4093 & Cirsium vulgare \\
\hline McCauley Ranch & 4093 & Convolvulus arvensis \\
\hline
\end{tabular}

\begin{tabular}{|c|c|c|}
\hline Alien Species & Elevation (ft) & Site \\
\hline Erodium cicutarium & 4001 & Wawona Stables \\
\hline Erodium cicutarium & 4039 & Government Stables (YV) \\
\hline Erodium cicutarium & 4093 & McCauley Ranch \\
\hline Filago gallica & 3960 & Hetch Hetchy Corral \\
\hline Galium parisiense & 3960 & Hetch Hetchy Corral \\
\hline Galium parisiense & 4093 & McCauley Ranch \\
\hline Herniaria hirsuta & 3960 & Hetch Hetchy Corral \\
\hline Herniaria hirsuta & 4001 & Wawona Stables \\
\hline Herniaria hirsuta & 4093 & McCauley Ranch \\
\hline Herniaria hirsuta & 7496 & Harden Lake Corral \\
\hline Herniaria hirsuta & 8632 & Tuolumne Stables \\
\hline Holcus lanatus & 4000 & Concession Stables (YV) \\
\hline Holcus lanatus & 4001 & Wawona Stables \\
\hline Holcus lanatus & 4093 & McCauley Ranch \\
\hline Hordeum marinum & 4093 & McCauley Ranch \\
\hline Hordeum murinum & 3960 & Hetch Hetchy Corral \\
\hline Hordeum murinum & 4000 & Concession Stables (YV) \\
\hline Hordeum murinum & 4001 & Wawona Stables \\
\hline Hordeum murinum & 4039 & Government Stables (YV) \\
\hline Hordeum murinum & 4093 & McCauley Ranch \\
\hline Hypericum perforatum & 4000 & Concession Stables (YV) \\
\hline Hypericum perforatum & 4093 & McCauley Ranch \\
\hline Hypochaeris glabra & 4001 & Wawona Stables \\
\hline Lactuca serriola & 3960 & Hetch Hetchy Corral \\
\hline Lactuca serriola & 4000 & Concession Stables (YV) \\
\hline Lactuca serriola & 4093 & McCauley Ranch \\
\hline Leucanthemum vulgare & 4000 & Concession Stables (YV) \\
\hline Lolium multiflorum & 4039 & Government Stables (YV) \\
\hline Lolium perenne & 4000 & Concession Stables (YV) \\
\hline Lychnis coronaria & 4000 & Concession Stables (YV) \\
\hline Malva parviflora & 3960 & Hetch Hetchy Corral \\
\hline Parapholis incurva & 3960 & Hetch Hetchy Corral \\
\hline Phleum pratense & 4000 & Concession Stables (YV) \\
\hline Phleum pratense & 4093 & McCauley Ranch \\
\hline Plantago lanceolata & 4000 & Concession Stables (YV) \\
\hline Plantago lanceolata & 4001 & Wawona Stables \\
\hline Plantago lanceolata & 8632 & Tuolumne Stables \\
\hline Poa annua & 3960 & Hetch Hetchy Corral \\
\hline Poa annua & 4000 & Concession Stables (YV) \\
\hline Poa annua & 4093 & McCauley Ranch \\
\hline Poa annua & 7496 & Harden Lake Corral \\
\hline Poa annua & 7967 & White Wolf Corral \\
\hline Poa annua & 8632 & Tuolumne Stables \\
\hline Poa bulbosa & 3960 & Hetch Hetchy Corral \\
\hline Poa bulbosa & 4000 & Concession Stables (YV) \\
\hline Poa bulbosa & 4001 & Wawona Stables \\
\hline Poa bulbosa & 4039 & Government Stables (YV) \\
\hline Poa pratensis & 3960 & Hetch Hetchy Corral \\
\hline Poa pratensis & 4000 & Concession Stables (YV) \\
\hline
\end{tabular}


Appendix F. (continued)

\begin{tabular}{|c|c|c|}
\hline Site & Elevation $(\mathrm{ft})$ & Alien Species \\
\hline McCauley Ranch & 4093 & Cynodon dactylon \\
\hline McCauley Ranch & 4093 & Cynosurus echinatus \\
\hline McCauley Ranch & 4093 & Erodium cicutarium \\
\hline McCauley Ranch & 4093 & Galium parisiense \\
\hline McCauley Ranch & 4093 & Herniaria hirsuta \\
\hline McCauley Ranch & 4093 & Holcus lanatus \\
\hline McCauley Ranch & 4093 & Hordeum marinum \\
\hline McCauley Ranch & 4093 & Hordeum murinum \\
\hline McCauley Ranch & 4093 & Hypericum perforatum \\
\hline McCauley Ranch & 4093 & Lactuca serriola \\
\hline McCauley Ranch & 4093 & Phleum pratense \\
\hline McCauley Ranch & 4093 & Poa annua \\
\hline McCauley Ranch & 4093 & Poa pratensis \\
\hline McCauley Ranch & 4093 & Polygonum arenastrum \\
\hline McCauley Ranch & 4093 & Rubus discolor \\
\hline McCauley Ranch & 4093 & Rumex acetosella \\
\hline McCauley Ranch & 4093 & Rumex crispus \\
\hline McCauley Ranch & 4093 & Sisymbrium altissimum \\
\hline McCauley Ranch & 4093 & Sonchus asper \\
\hline McCauley Ranch & 4093 & Spergularia nubra \\
\hline McCauley Ranch & 4093 & Stellaria media \\
\hline McCauley Ranch & 4093 & Tragopogon dubius \\
\hline McCauley Ranch & 4093 & Trifolium repens \\
\hline McCauley Ranch & 4093 & Verbascum thapsus \\
\hline McCauley Ranch & 4093 & Vulpia myuros \\
\hline Tuolumne Stables & 8632 & Dactylis glomerata \\
\hline Tuolumne Stables & 8632 & Herniaria hirsuta \\
\hline Tuolumne Stables & 8632 & Plantago lanceolata \\
\hline Tuolumne Stables & 8632 & Poa annua \\
\hline Tuolumne Stables & 8632 & Poa pratensis \\
\hline Tuolumne Stables & -8632 & Spergularia rubra \\
\hline Tuolumne Stables & 8632 & Taraxacum officinale \\
\hline Tuolumne Stables & 8632 & Trifolium repens \\
\hline Wawona Stables & 4001 & Aira caryophyllea \\
\hline Wawona Stables & 4001 & Bromus diandrus \\
\hline Wawona Stables & 4001 & Bromus hordeaceus \\
\hline Wawona Stables & 4001 & Bromus tectorum \\
\hline Wawona Stables & 4001 & Chamomilla suaveolens \\
\hline Wawona Stables & 4001 & Cynosurus echinatus \\
\hline Wawona Stables & 4001 & Erodium cicutarium \\
\hline Wawona Stables & 4001 & Herniaria hirsuta \\
\hline Wawona Stables & 4001 & Holcus lanatus \\
\hline Wawona Stables & 4001 & Hordeum murinum \\
\hline Wawona Stables & 4001 & Hypochaeris glabra \\
\hline Wawona Stables & 4001 & Plantago lanceolata \\
\hline Wawona Stables & 4001 & Poa bulbosa \\
\hline Wawona Stables & 4001 & Poa pratensis \\
\hline Wawona Stables & 4001 & Polygonum arenastrum \\
\hline Wawona Stables & 4001 & Rumex acetosella \\
\hline
\end{tabular}

\begin{tabular}{|c|c|c|}
\hline Alien Species & Elevation ( $\mathrm{ft}$ ) & Site \\
\hline Poa pratensis & 4001 & Wawona Stables \\
\hline Poa pratensis & 4093 & McCauley Ranch \\
\hline Poa pratensis & 7496 & Harden Lake Corral \\
\hline Poa pratensis & 7967 & White Wolf Corral \\
\hline Poa pratensis & 8632 & Tuolumne Stables \\
\hline Poa pratensis & 8695 & Government Corrals (Tuol) \\
\hline Polygonum arenastrum & 3960 & Hetch Hetchy Corral \\
\hline Polygonum arenastrum & 4000 & Concession Stables (YV) \\
\hline Polygonum arenastrum & 4001 & Wawona Stables \\
\hline Polygonum arenastrum & 4093 & McCauley Ranch \\
\hline Polygonum arenastrum & 7967 & White Wolf Corral \\
\hline Polypogon maritimus & 3960 & Hetch Hetchy Corral \\
\hline Rubus discolor & 4000 & Concession Stables (YV) \\
\hline Rubus discolor & 4093 & McCauley Ranch \\
\hline Rumex acetosella & 3960 & Hetch Hetchy Corral \\
\hline Rumex acetosella & 4000 & Concession Stables (YV) \\
\hline Rumex acetosella & 4001 & Wawona Stables \\
\hline Rumex acetosella & 4093 & McCauley Ranch \\
\hline Rumex acetosella & 7496 & Harden Lake Corral \\
\hline Rumex acetosella & 7967 & White Wolf Corral \\
\hline Rumex crispus & 3960 & Hetch Hetchy Corral \\
\hline Rumex crispus & 4000 & Concession Stables (YV) \\
\hline Rumex crispus & 4093 & McCauley Ranch \\
\hline Silene latifolia & 4000 & Concession Stables (YV) \\
\hline Sisymbrium altissimum & 4001 & Wawona Stables \\
\hline Sisymbrium altissimum & 4039 & Government Stables (YV) \\
\hline Sisymbrium altissimum & 4093 & McCauley Ranch \\
\hline Sonchus asper & 4093 & McCauley Ranch \\
\hline Sonchus oleraceus & 3960 & Hetch Hetchy Corral \\
\hline Sonchus oleraceus & 4000 & Concession Stables (YV) \\
\hline Sonchus oleraceus & 4001 & Wawona Stables \\
\hline Spergularia rubra & 4001 & Wawona Stables \\
\hline Spergularia rubra & 4093 & McCauley Ranch \\
\hline Spergularia rubra & 7496 & Harden Lake Corral \\
\hline Spergularia rubra & 7967 & White Wolf Corral \\
\hline Spergularia rubra & 8632 & Tuolumne Stables \\
\hline Stellaria media & 3960 & Hetch Hetchy Corral \\
\hline Stellaria media & 4000 & Concession Stables (YV) \\
\hline Stellaria media & 4039 & Government Stables (YV) \\
\hline Stellaria media & 4093 & McCauley Ranch \\
\hline Stellaria media & 7967 & White Wolf Corral \\
\hline Taraxacum officinale & 4000 & Concession Stables (YV) \\
\hline Taraxacum officinale & 7832 & Glen Aulin High Sierra Camp \\
\hline Taraxacum officinale & 7967 & White Wolf Corral \\
\hline Taraxacum officinale & 8632 & Tuolumne Stables \\
\hline Torilis arvensis & 3960 & Hetch Hetchy Corral \\
\hline Tragopogon dubius & 4000 & Concession Stables (YV) \\
\hline Tragopogon dubius & 4093 & McCauley Ranch \\
\hline Trifolium repens & 4000 & Concession Stables (YV) \\
\hline
\end{tabular}


Appendix F. (continued)

\begin{tabular}{|l|cl|}
\hline \multicolumn{1}{|c|}{ Site } & Elevation (ft) & \multicolumn{1}{c|}{ Alien Species } \\
\hline Wawona Stables & 4001 & Sisymbrium altissimum \\
Wawona Stables & 4001 & Sonchus oleraceus \\
Wawona Stables & 4001 & Spergularia rubra \\
Wawona Stables & 4001 & Vulpia myuros \\
White Wolf Corral & 7967 & Capsella bursa-pastoris \\
White Wolf Corral & 7967 & Chamomilla suaveolens \\
White Wolf Corral & 7967 & Poa annua \\
White Wolf Corral & 7967 & Poa pratensis \\
White Wolf Corral & 7967 & Polygonum arenastrum \\
White Wolf Corral & 7967 & Rumex acetosella \\
White Wolf Corral & 7967 & Spergularia rubra \\
White Wolf Corral & 7967 & Stellaria media \\
White Wolf Corral & 7967 & Taraxacum officinale \\
White Wolf Corral & 7967 & Trifolium repens \\
\hline
\end{tabular}

\begin{tabular}{|l|c|l|}
\hline \multicolumn{1}{|c|}{ Alien Species } & Elevation (ft) & \multicolumn{1}{c|}{ Site } \\
\hline Trifolium repens & 4093 & McCauley Ranch \\
Trifolium repens & 7496 & Harden Lake Corral \\
Trifolium repens & 7832 & Glen Aulin High Sierra Camp \\
Trifolium repens & 7967 & White Wolf Corral \\
Trifolium repens & 8632 & Tuolumne Stables \\
Urtica urens & 4039 & Government Stables (YV) \\
Verbascum thapsus & 4000 & Concession Stables (YV) \\
Verbascum thapsus & 4093 & McCauley Ranch \\
Veronica persica & 7496 & Harden Lake Corral \\
Vulpia myuros & 3960 & Hetch Hetchy Corral \\
Vulpia myuros & 4000 & Concession Stables (YV) \\
Vulpia myuros & 4001 & Wawona Stables \\
Vulpia myuros & 4039 & Government Stables (YV) \\
Vulpia myuros & 4093 & McCauley Ranch \\
\hline
\end{tabular}

\begin{tabular}{|lcc|}
\hline \multicolumn{3}{|c|}{ Species Richness Summary - by Corral/Stable Site } \\
Site & Elien Species \\
Concession Stables (YV) & 4000 & Richness \\
Glen Aulin High Sierra Camp & 7832 & 33 \\
Government Stables (YV) & 4039 & 2 \\
Government Corrals (Tuol) & 8695 & 13 \\
Harden Lake Corral & 7496 & 2 \\
Hetch Hetchy Corral & 3960 & 8 \\
McCauley Ranch & 4093 & 32 \\
Tuolumne Stables & 8632 & 33 \\
Wawona Stables & 4001 & 8 \\
White Wolf Corral & 7967 & 20 \\
& & 10 \\
Species of Corrals/Stables & & Total $=\mathbf{6 3}$ \\
\hline
\end{tabular}

\begin{tabular}{|lcc|}
\hline Species Richness Summary - by Richness level & \\
Site & Elevation (ft) & $\begin{array}{c}\text { Alien Species } \\
\text { Richness }\end{array}$ \\
Glen Aulin High Sierra Cmp & 7832 & 2 \\
Government Corrals (Tuol) & 8695 & 2 \\
Harden Lake Corral & 7496 & 8 \\
Tuolumne Stables & 8632 & 8 \\
White Wolf Corral & 7967 & 10 \\
Government Stables (YV) & 4039 & 13 \\
Wawona Stables & 4001 & 20 \\
Hetch Hetchy Corral & 3960 & 32 \\
Concession Stables(YV) & 4000 & 33 \\
McCauley Ranch & 4093 & 33 \\
& & \\
Species of Corrals/Stables & & Total = $\mathbf{6 3}$ \\
\hline
\end{tabular}


Appendix G. Statewide distributions of priority alien plant species.

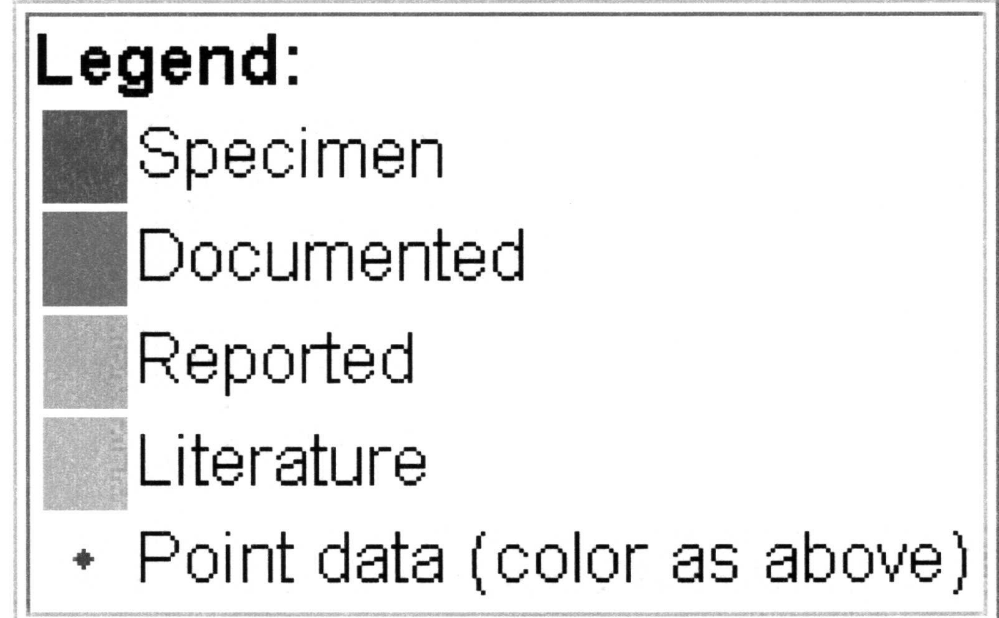


Appendix G. Statewide distributions of priority alien plant species.

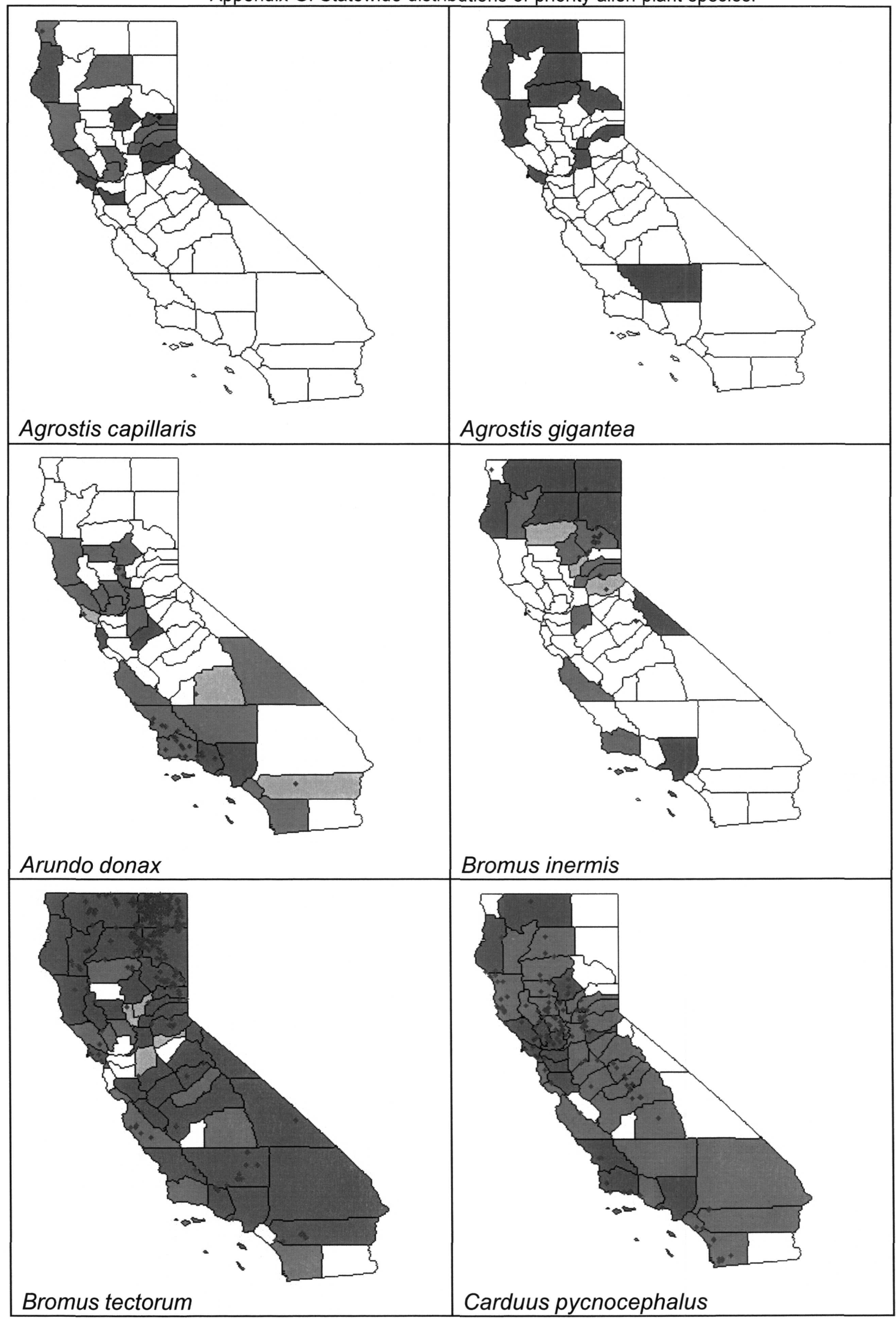


Appendix G (Continued). Statewide distributions of priority alien plant species.

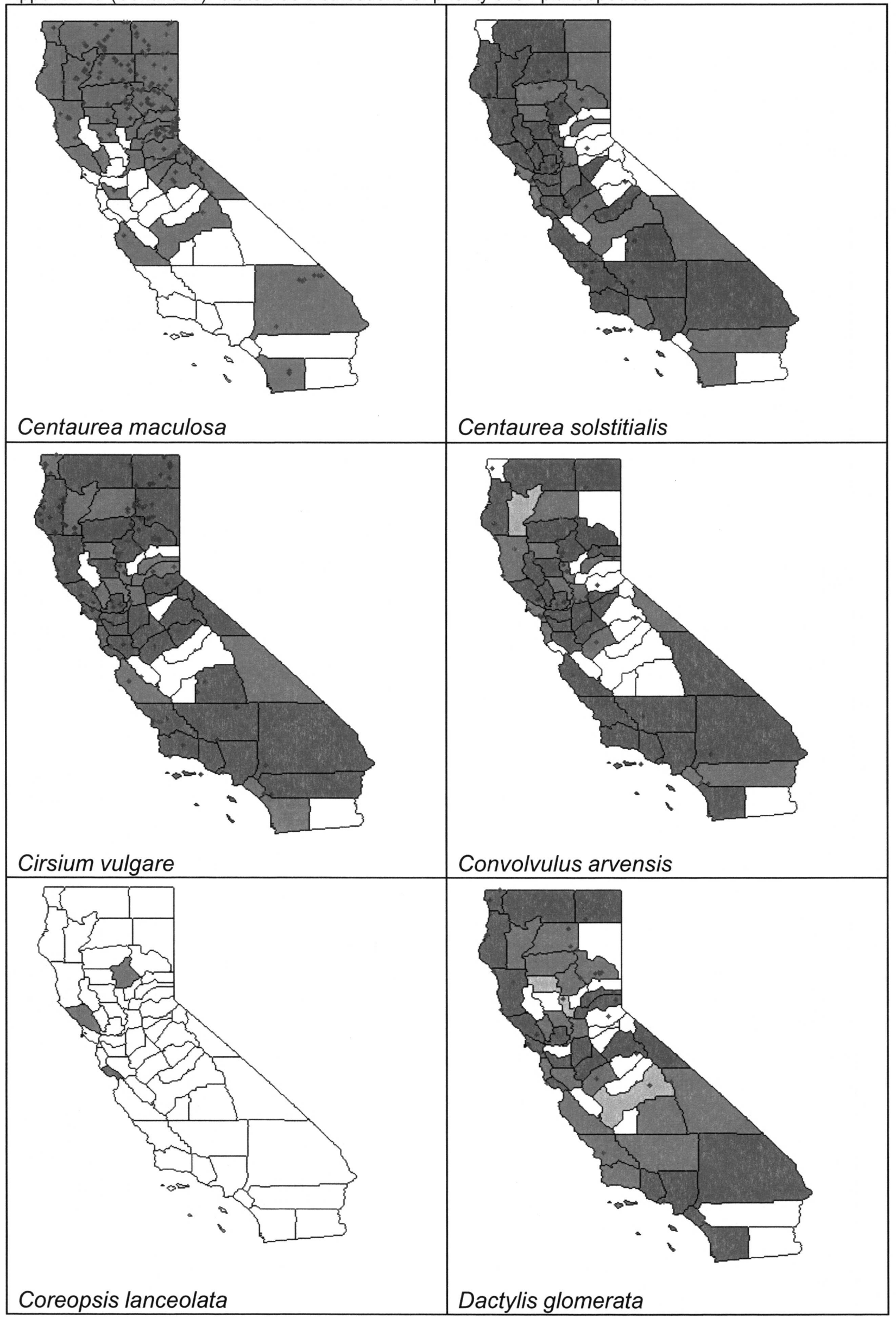


Appendix G (Continued). Statewide distributions of priority alien plant species.
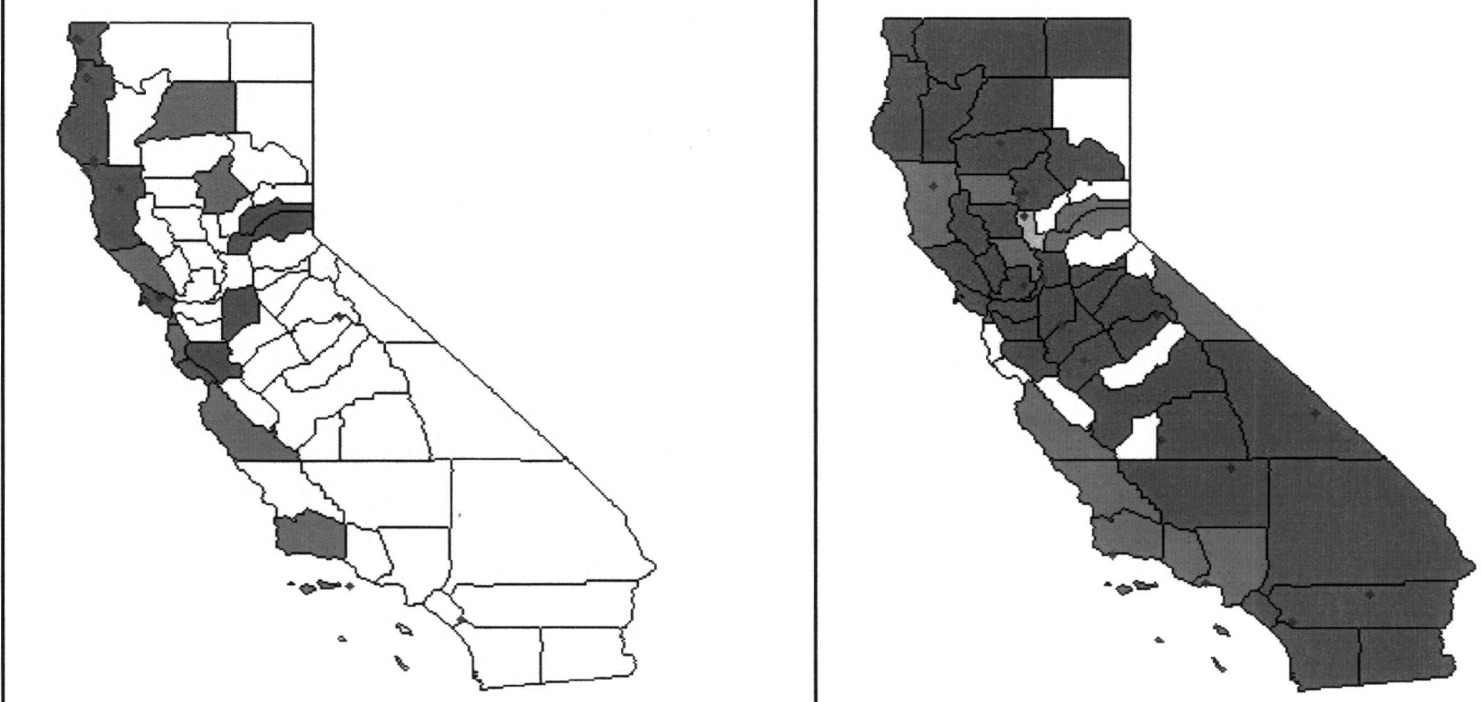

Digitalis purpurea

Echinochloa crus-galli

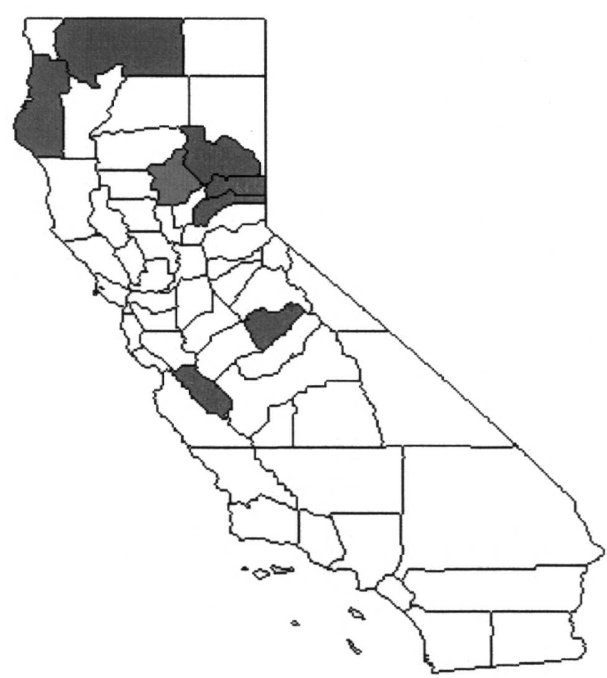

Erigeron strigosus

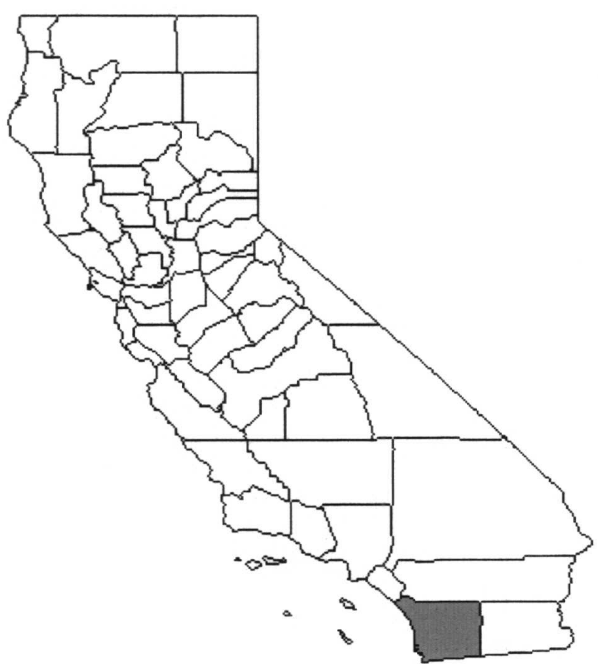

Eucalyptus citriodora

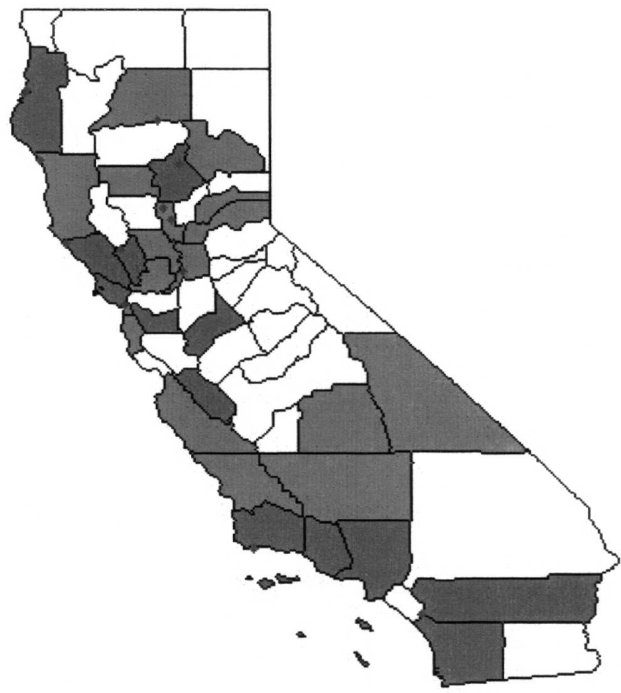

Festuca arundinacea

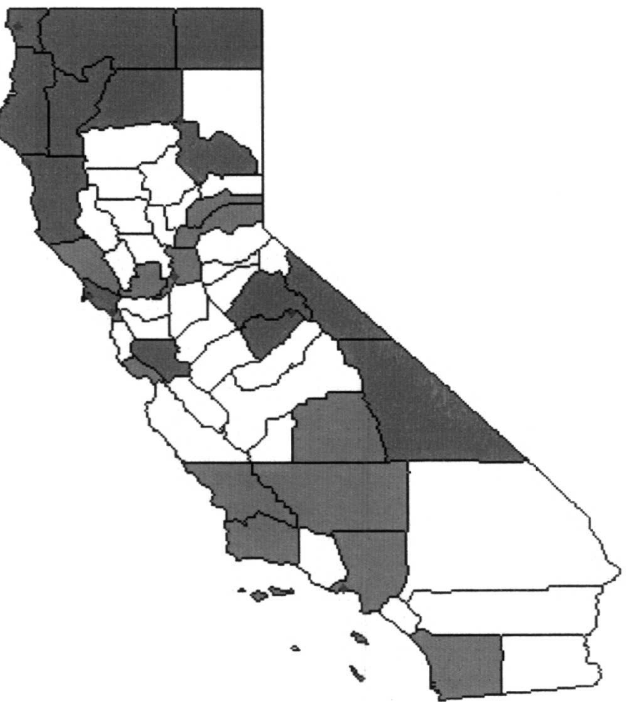

Festuca pratensis 
Appendix G (Continued). Statewide distributions of priority alien plant species.
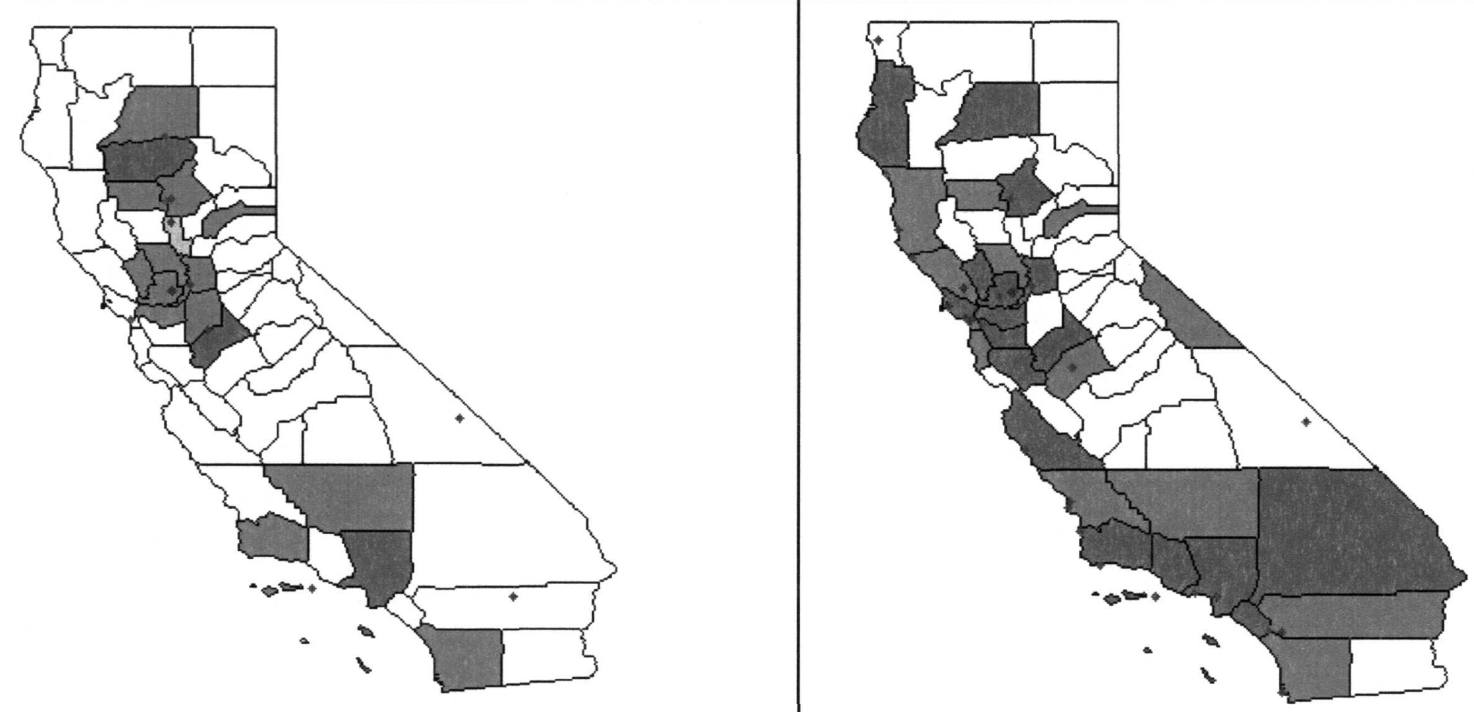

Ficus carica

Foeniculum vulgare
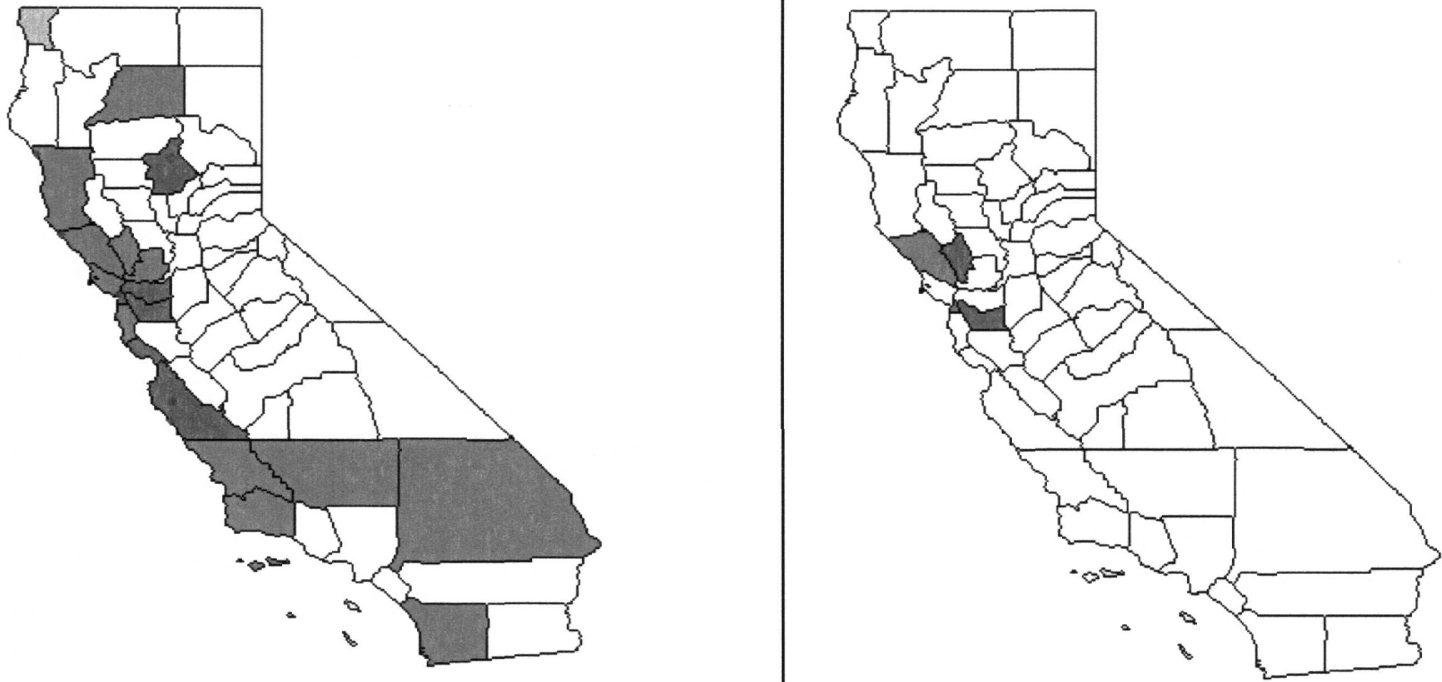

Genista monspessulana

Geranium robertianum

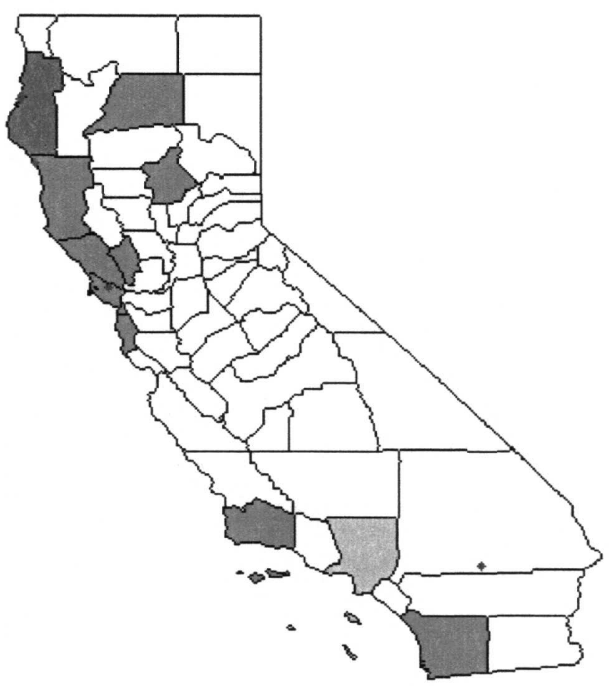

Hedera helix

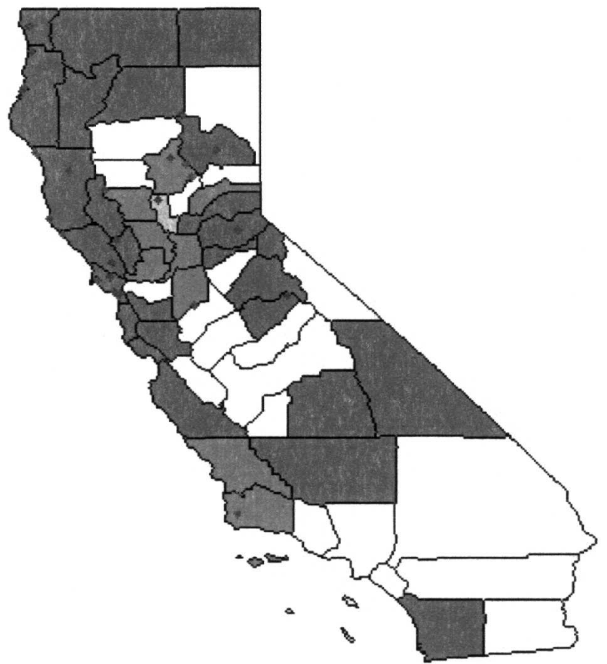

Holcus lanatus 
Appendix G (Continued). Statewide distributions of priority alien plant species.

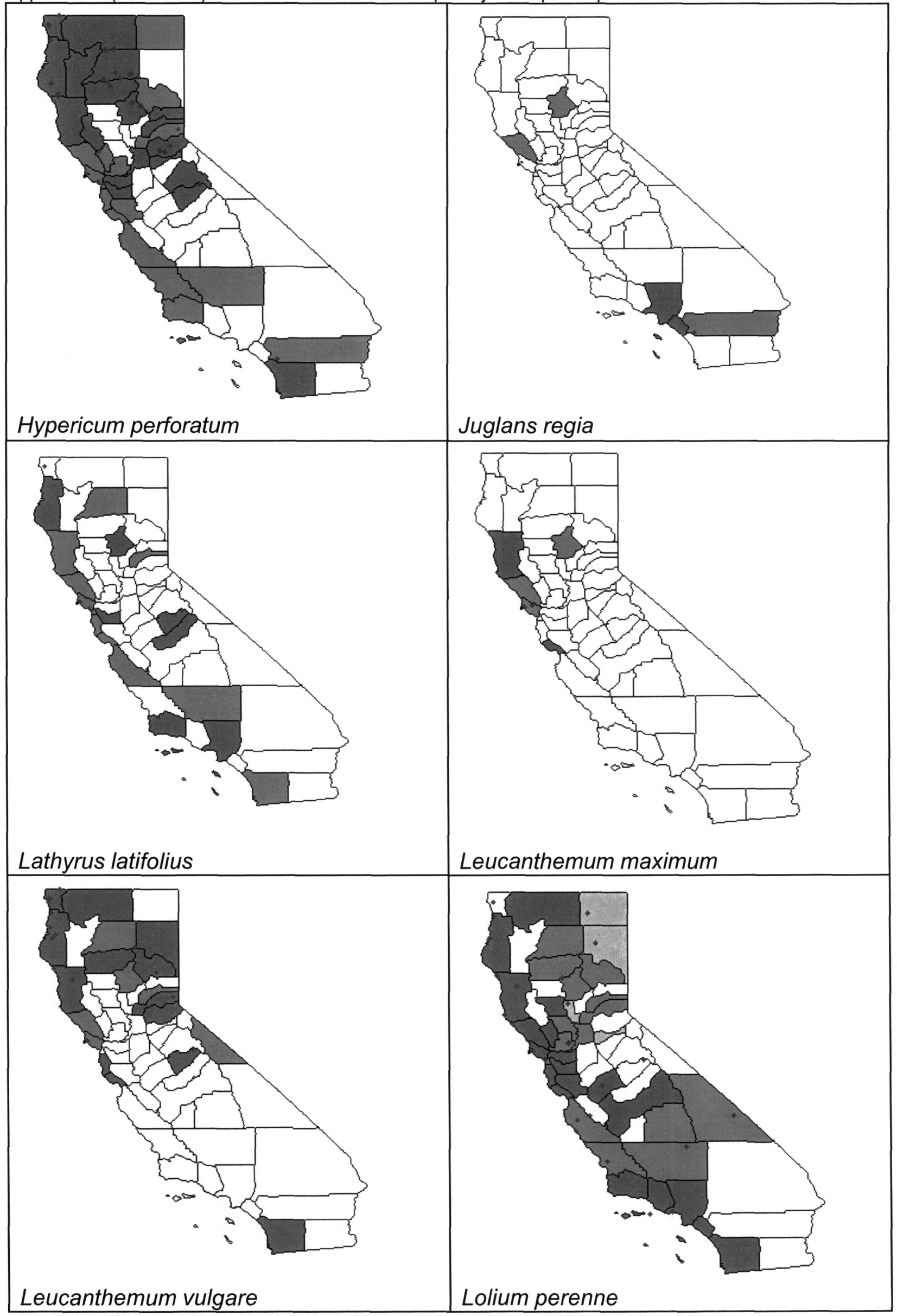


Appendix G (Continued). Statewide distributions of priority alien plant species.
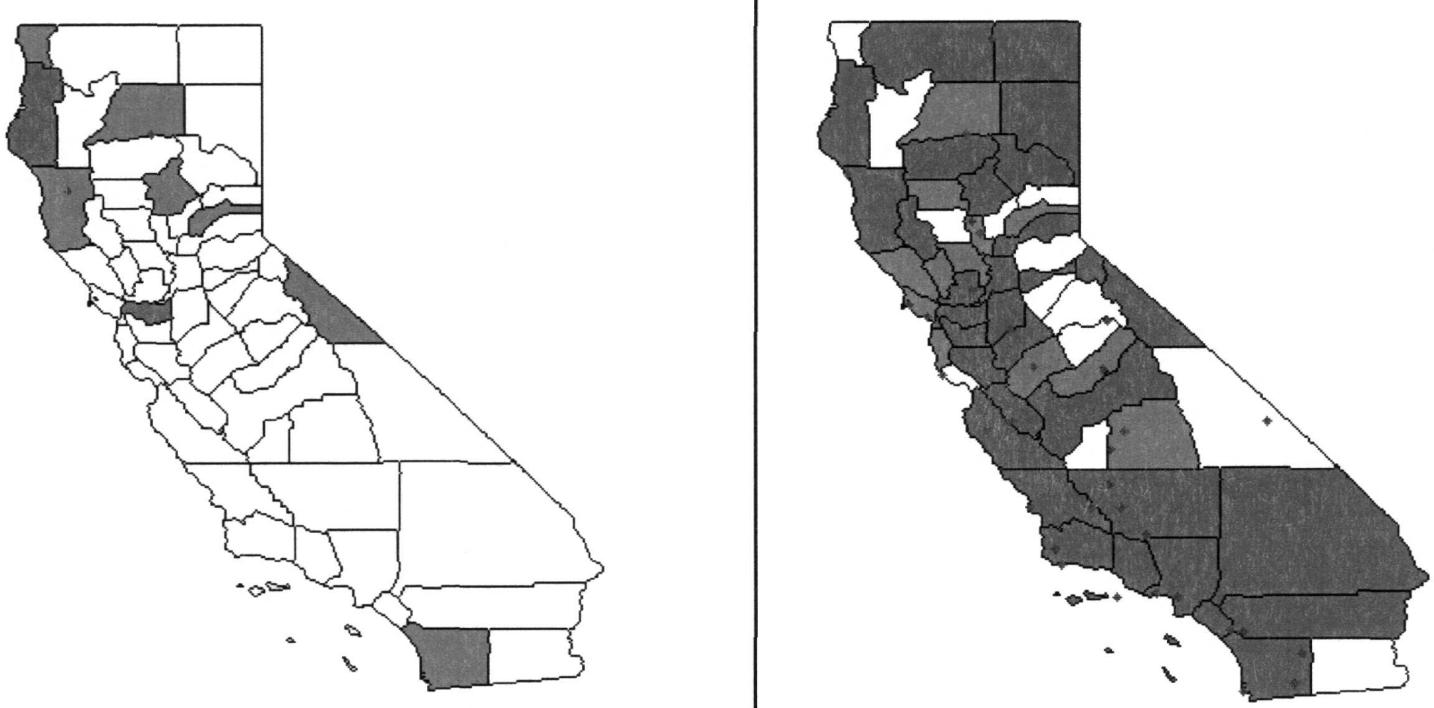

Malus sylvestris

Marrubium vulgare

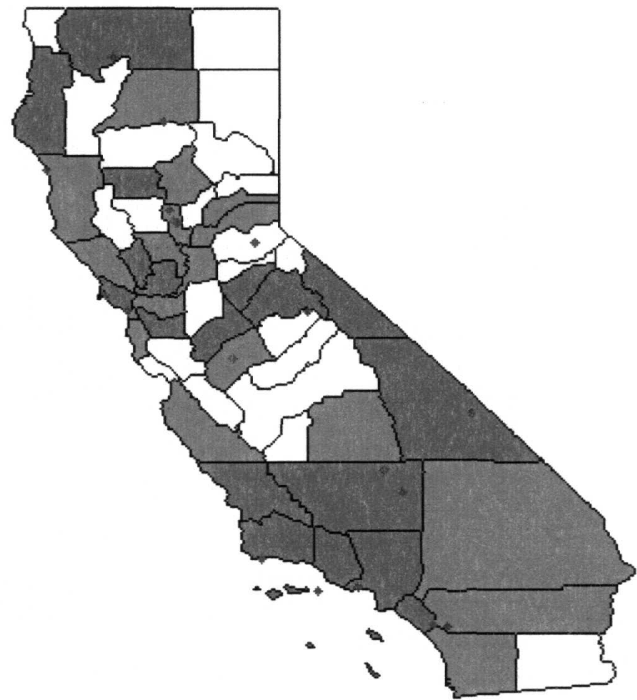

Medicago sativa

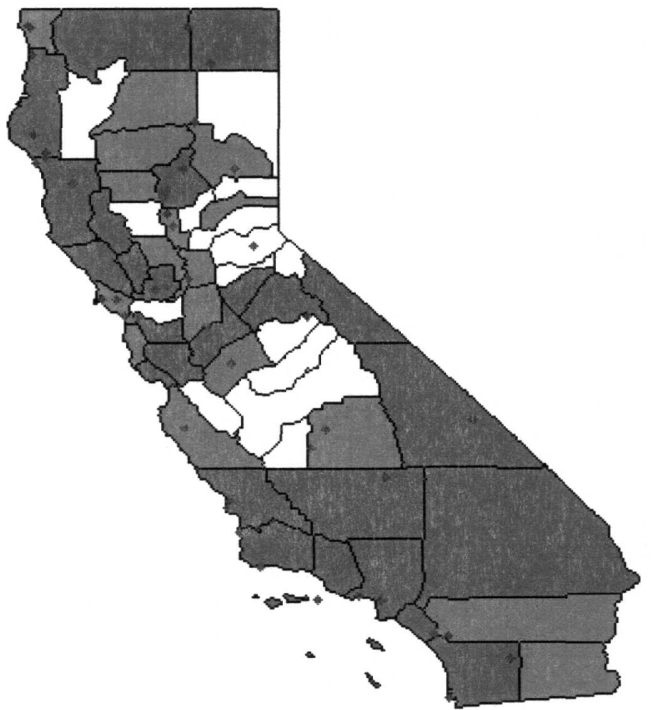

Melilotus alba

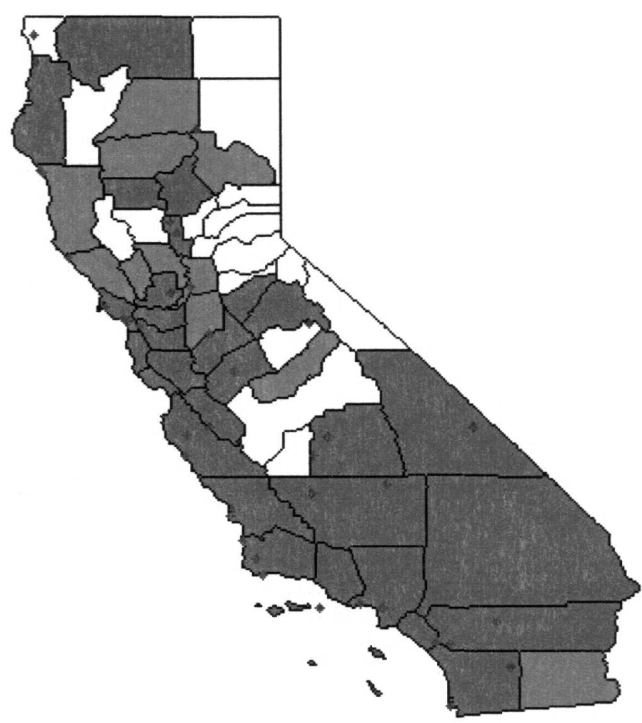

Melilotus indica

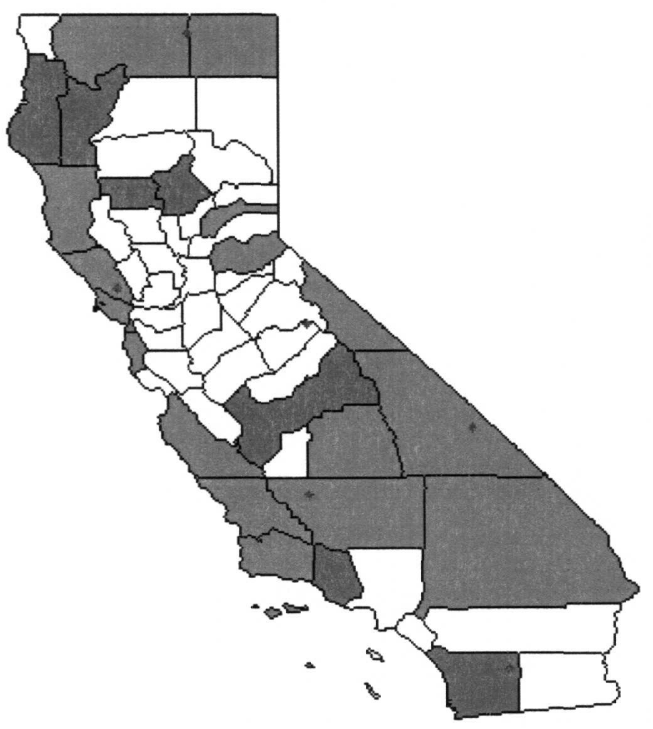

Melilotus officinalis 
Appendix G (Continued). Statewide distributions of priority alien plant species.

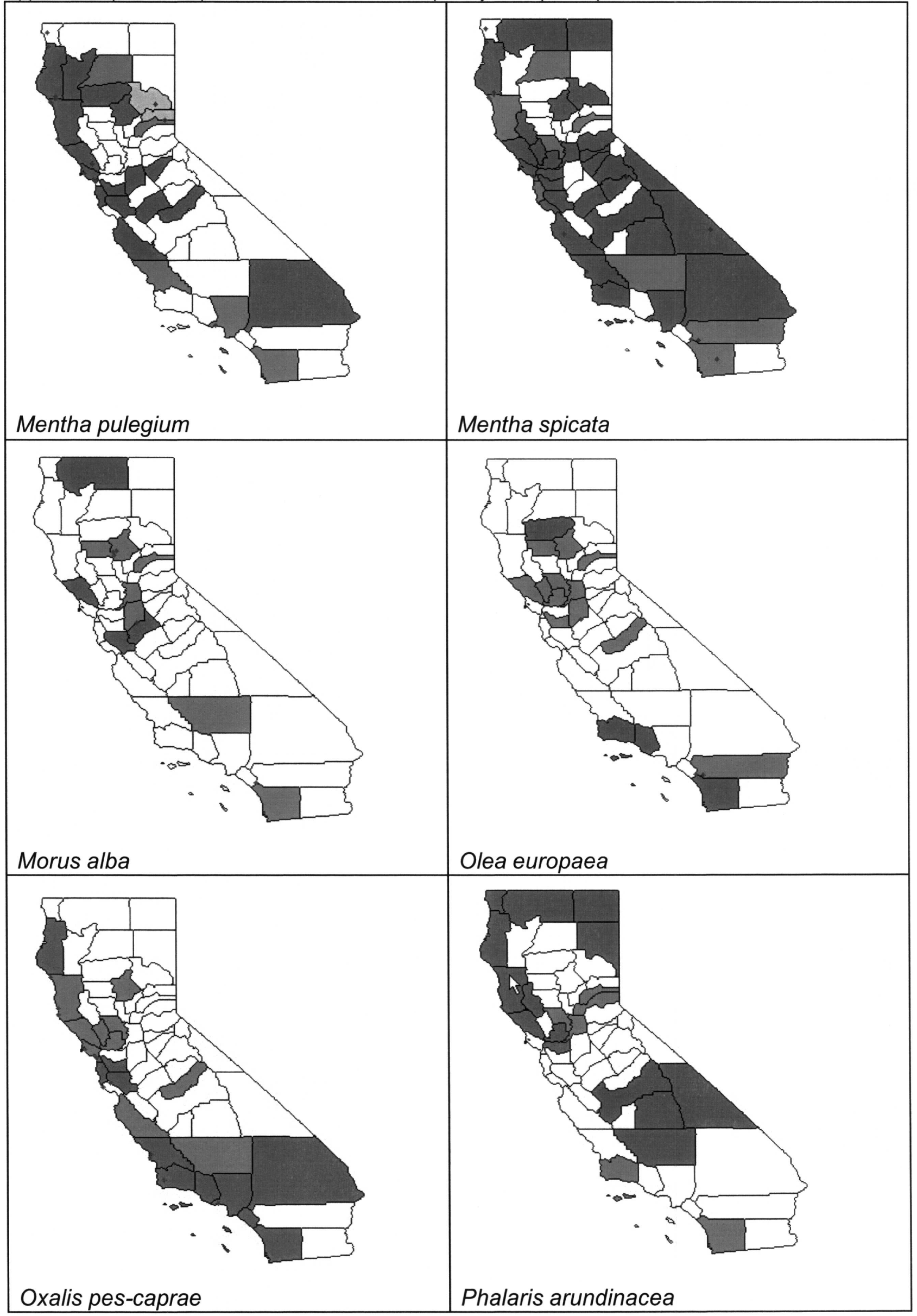


Appendix G (Continued). Statewide distributions of priority alien plant species.

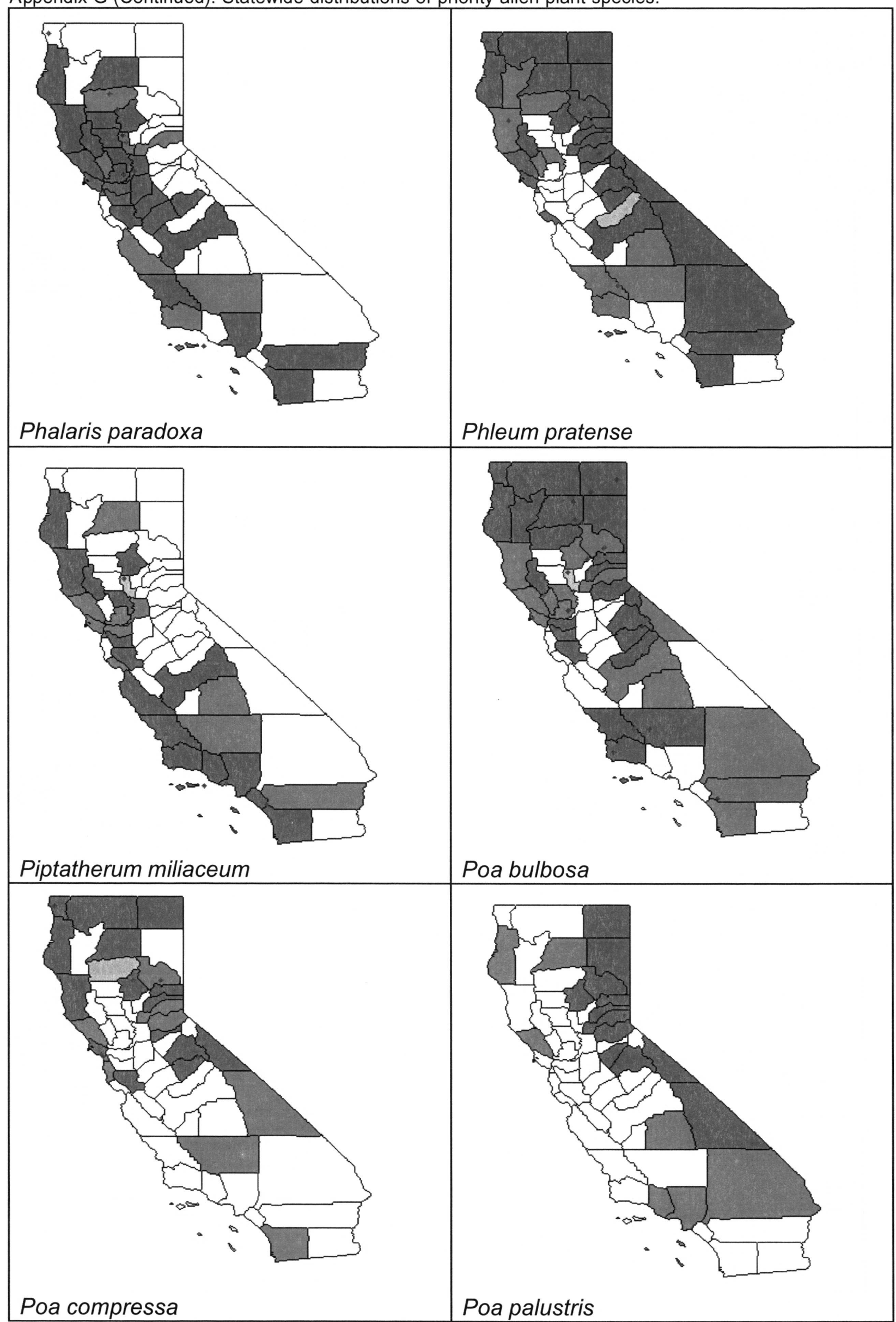


Appendix G (Continued). Statewide distributions of priority alien plant species.

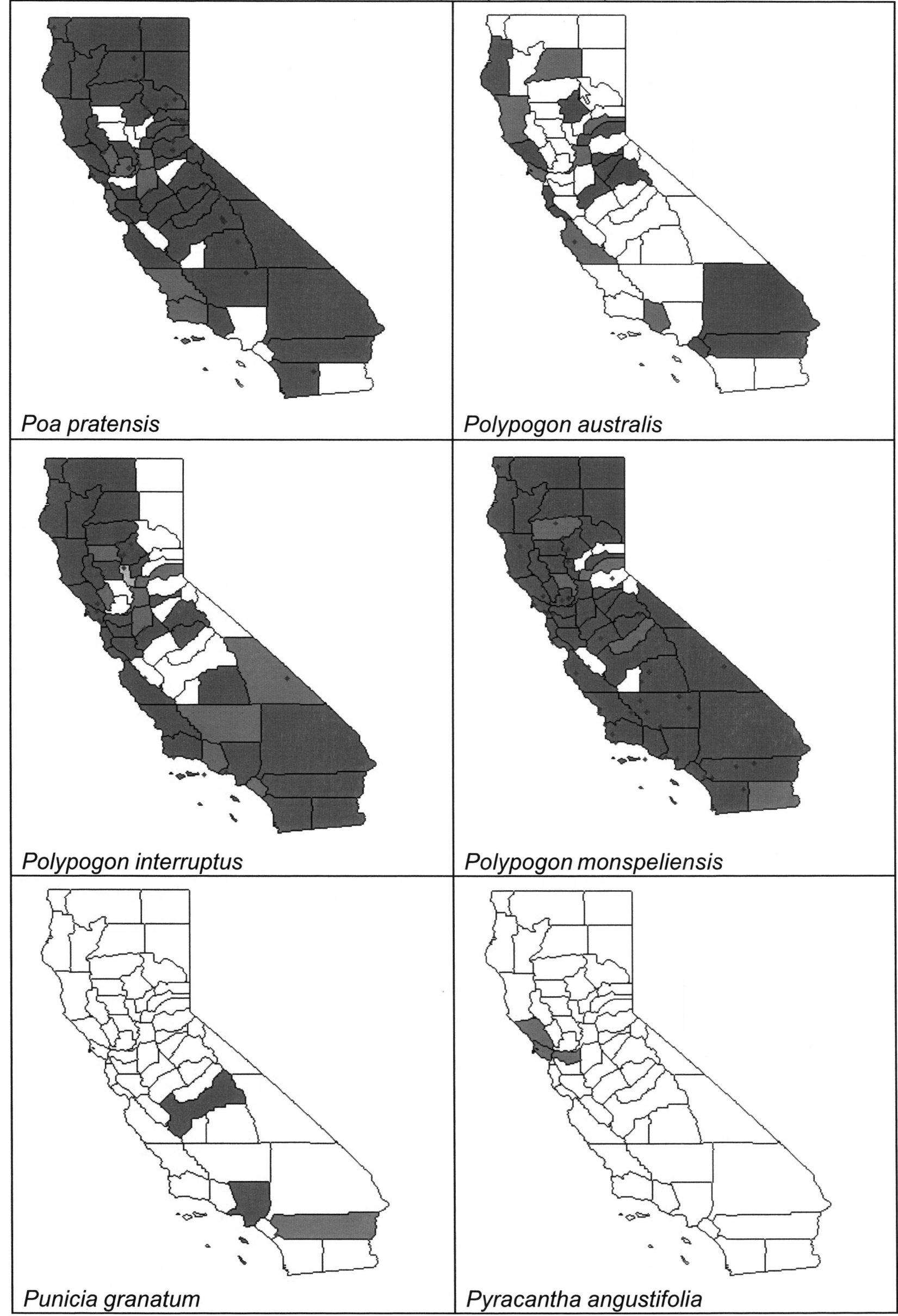


Appendix G (Continued). Statewide distributions of priority alien plant species.

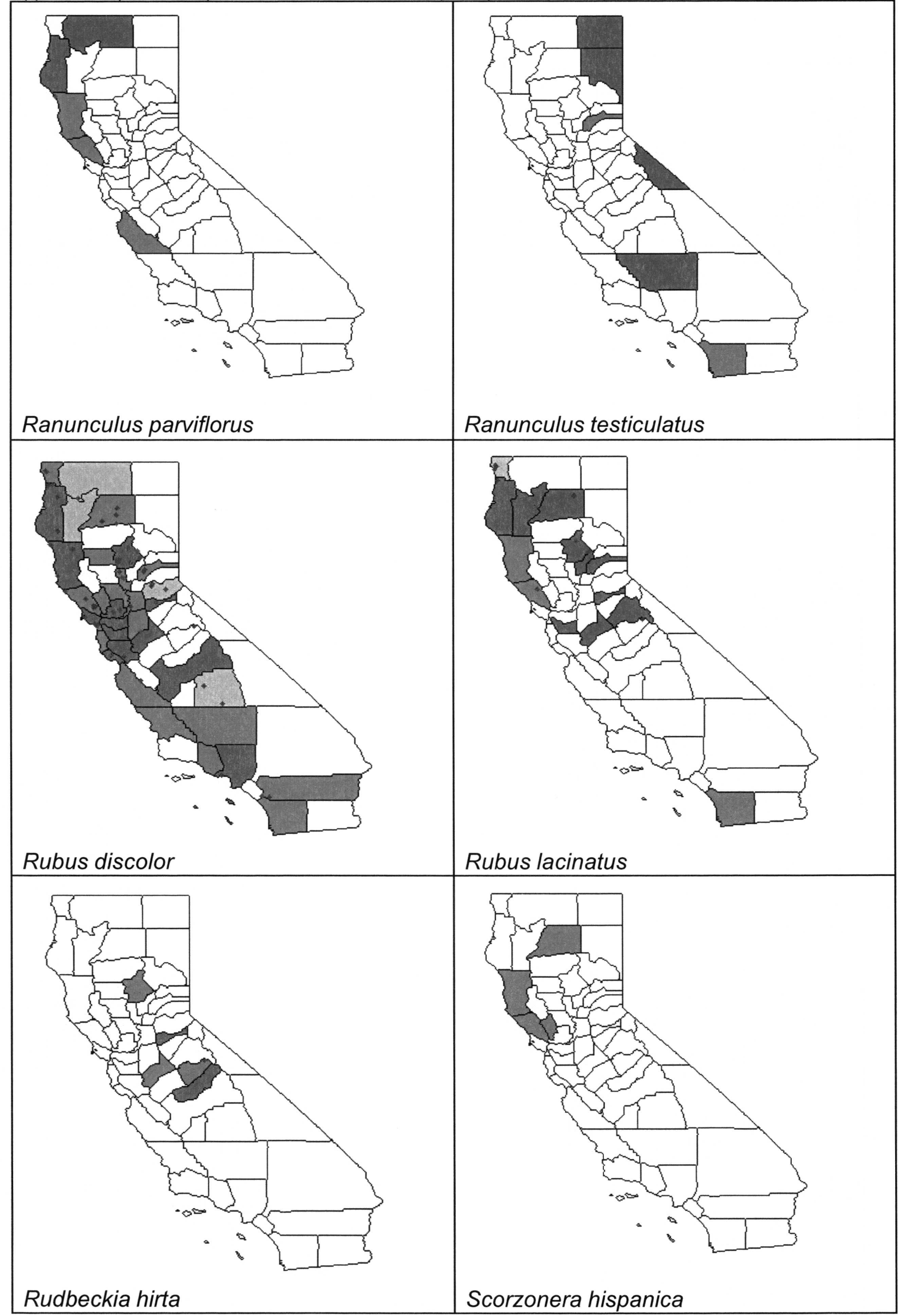


Appendix G (Continued). Statewide distributions of priority alien plant species.

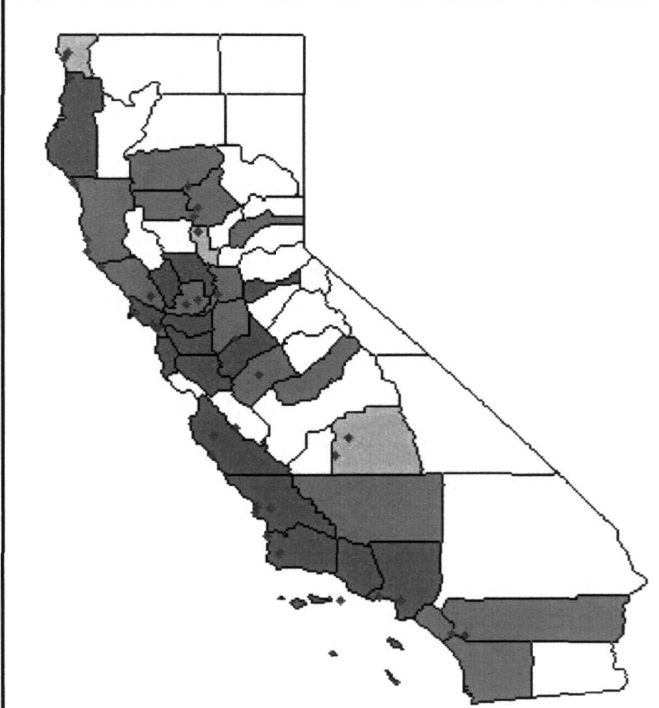

\section{Silybum marianum}

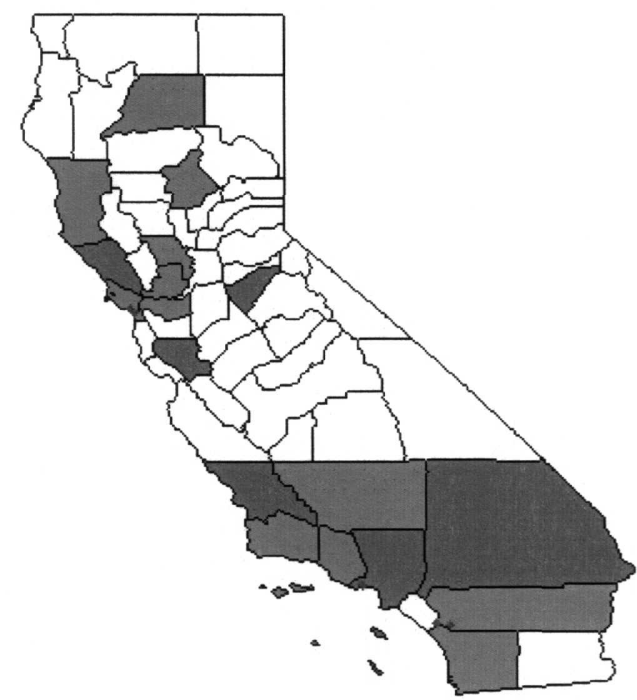

\section{Spartium junceum}

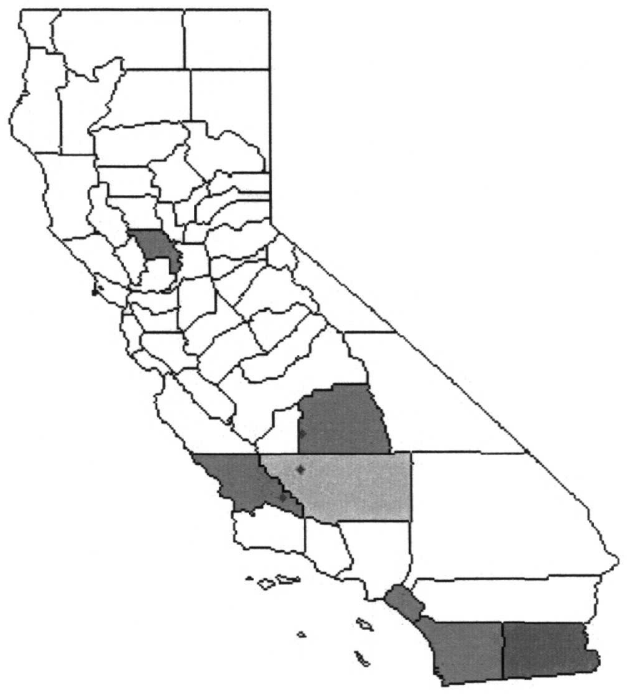

Tamarix chinensis

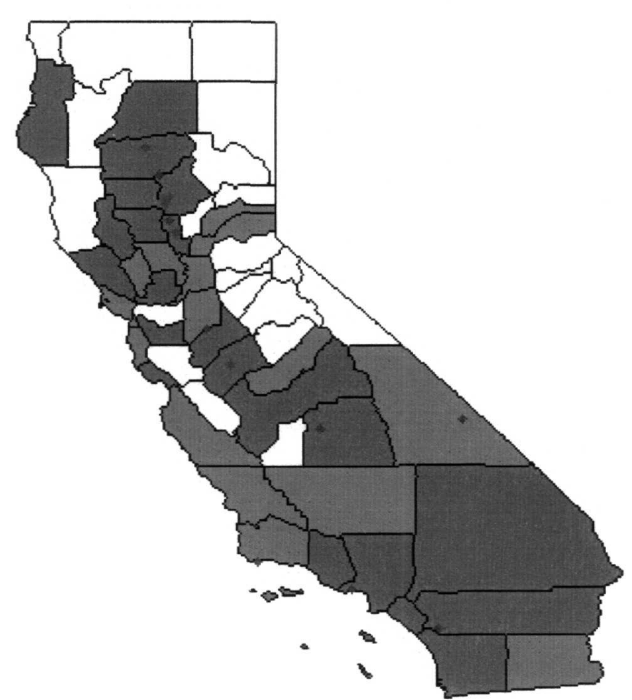

Sorghum halepense

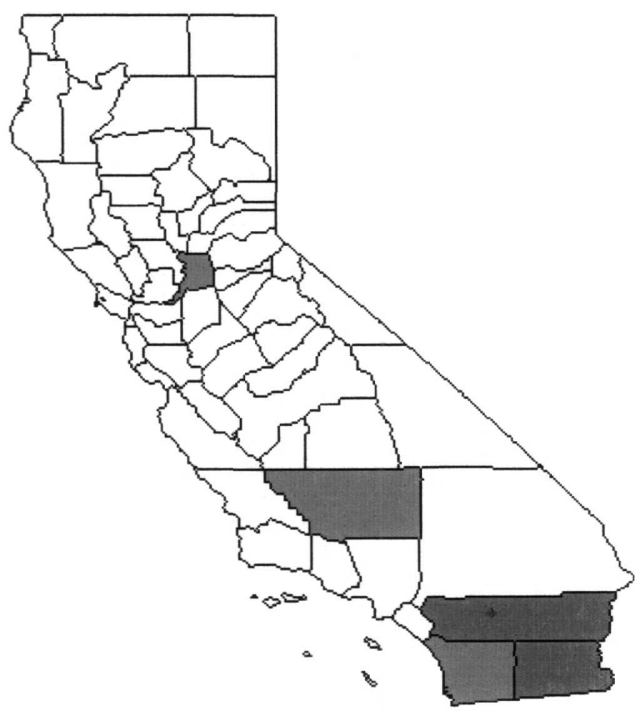

Tamarix aphylla

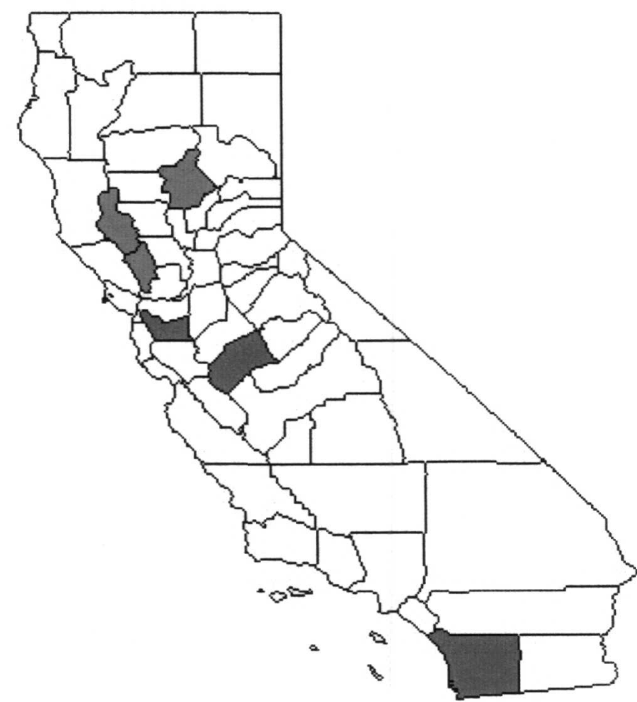

Tamarix gallica 
Appendix G (Continued). Statewide distributions of priority alien plant species.

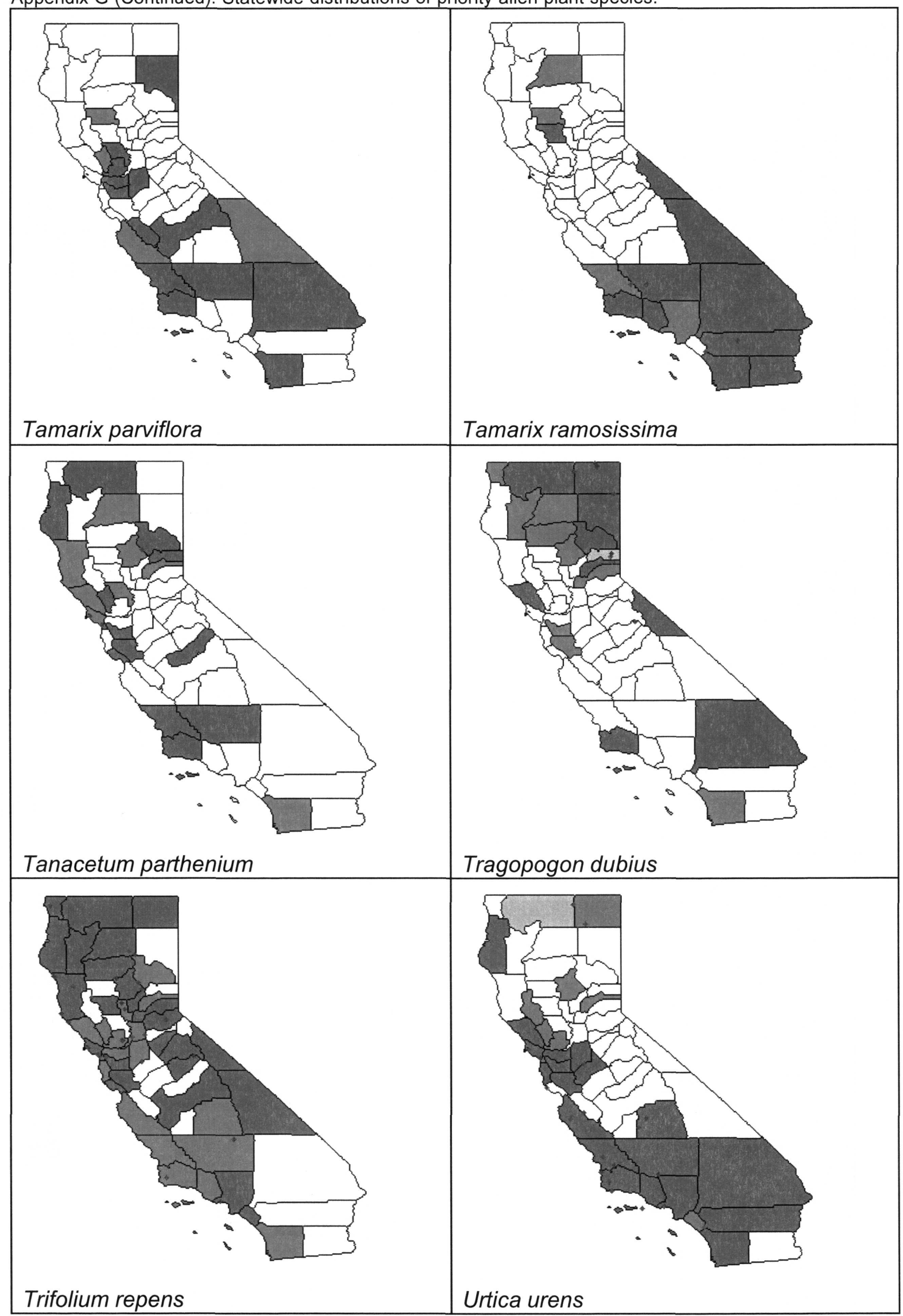


Appendix G (Continued). Statewide distributions of priority alien plant species.

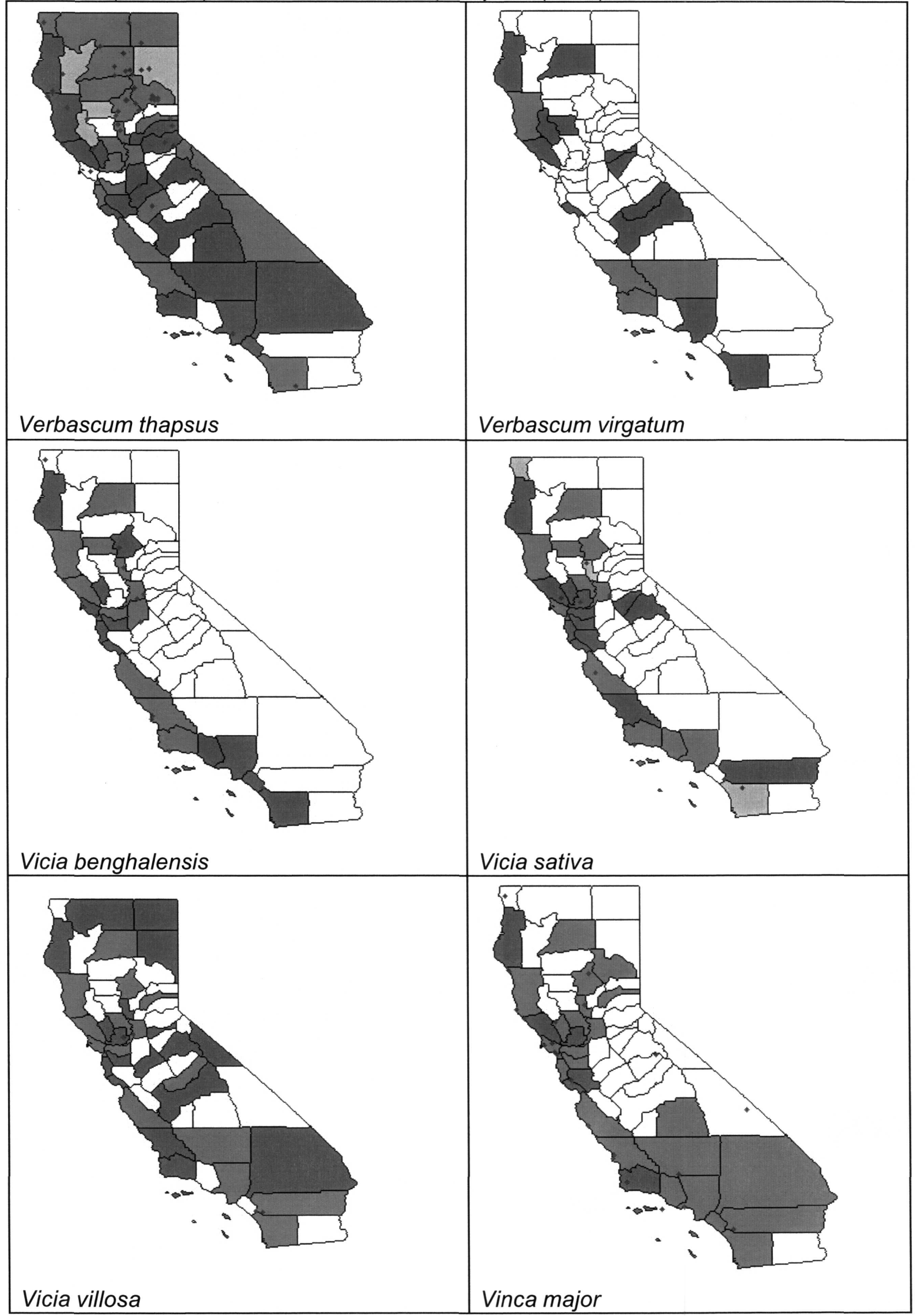


Appendix G (Continued). Statewide distributions of priority alien plant species.

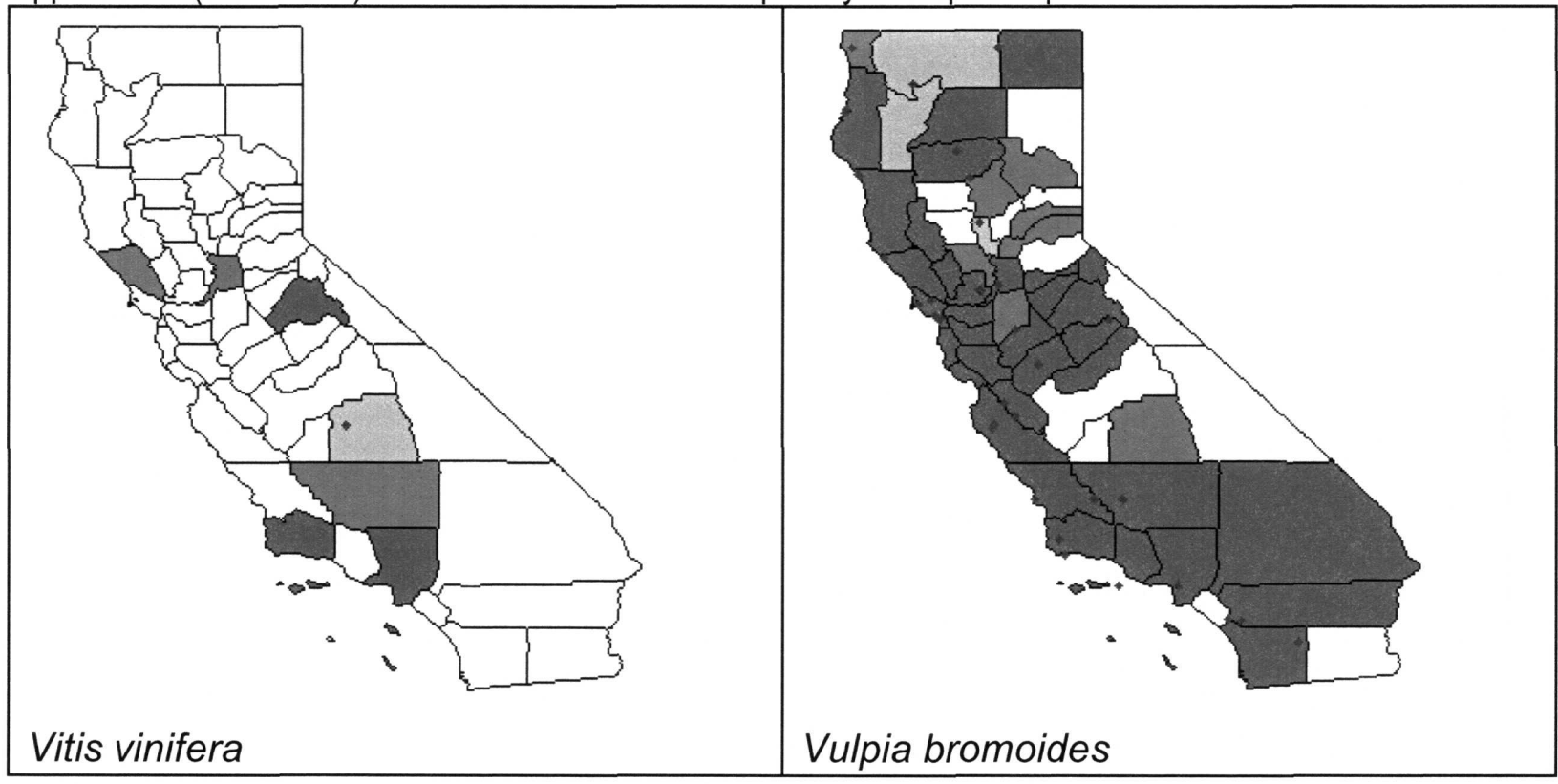




\section{Sequoia and Kings Canyon National Parks Survey Areas}

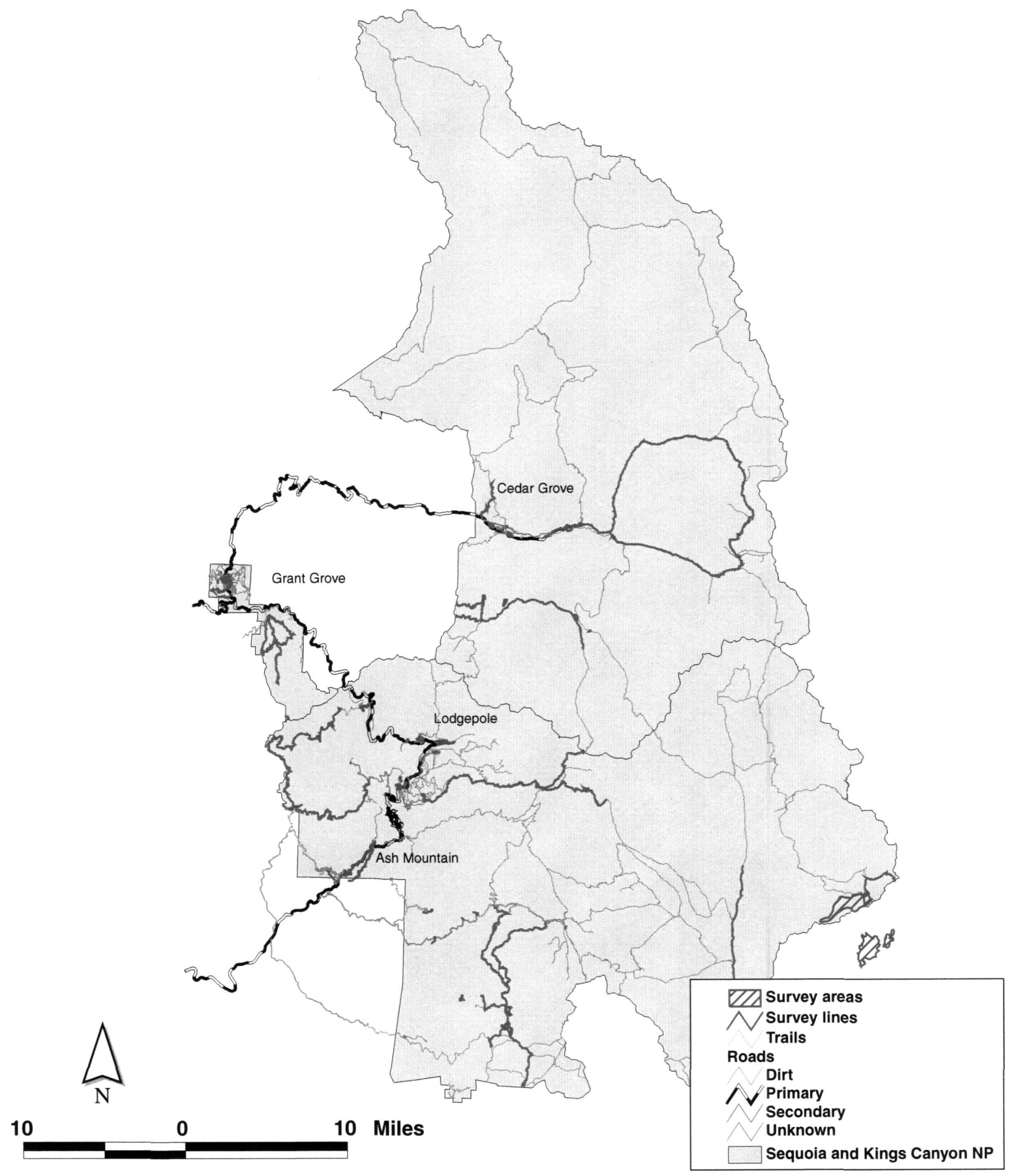

Map 1. Alien plant surveys of disturbed areas in Sequoia and Kings Canyon National Parks, 1996, 1997 and 1998. 


\section{Broad Distribution Priority \#3 Alien Plant Species}

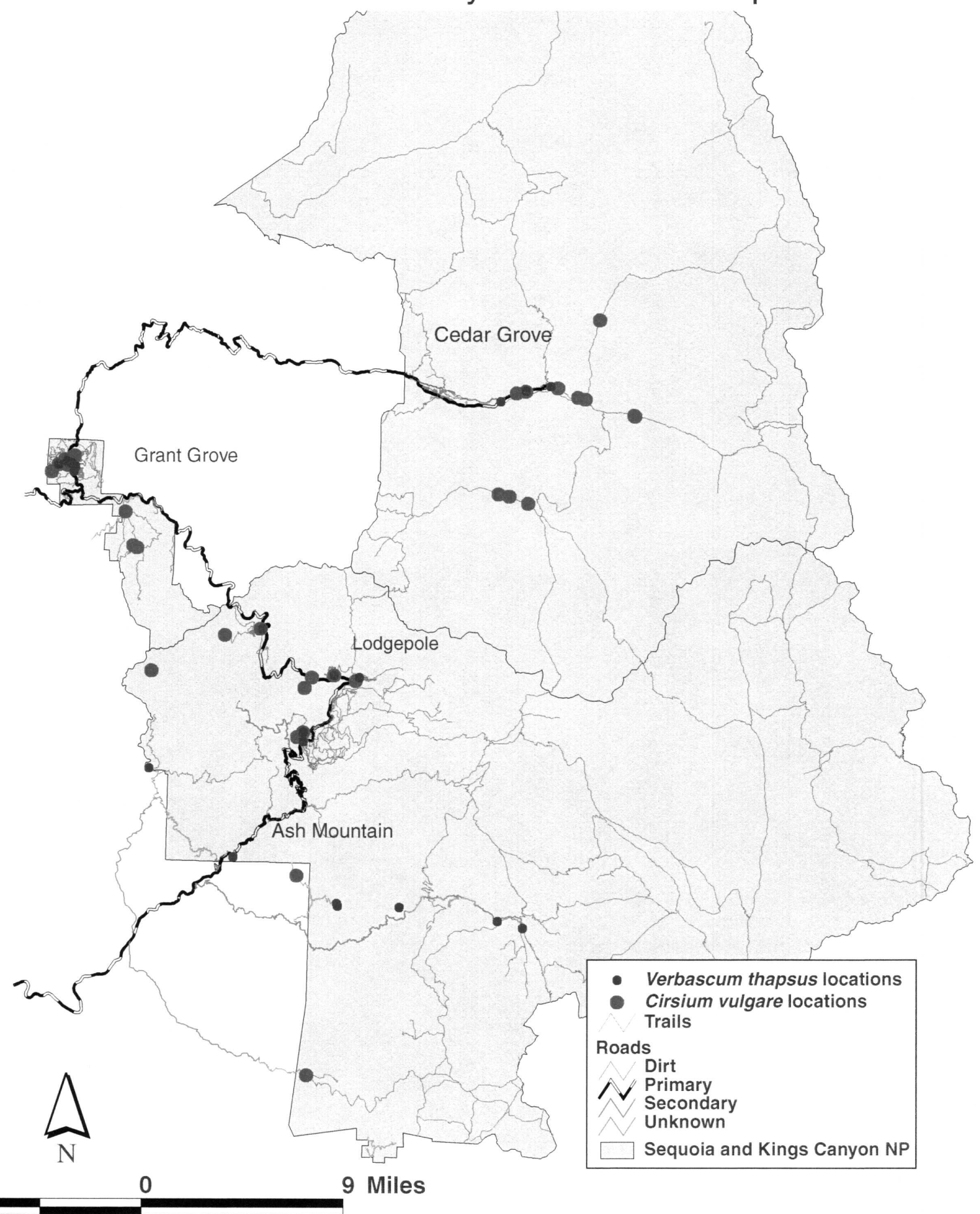

Map 2. Cirsium vulgare and Verbascum thapsus distributions based on alien plant surveys of disturbed areas in Sequoia and Kings Canyon National Parks, 1996, 1997 and 1998. 


\section{Localized Wildland Priority \#1 Alien Plant Species - Map 1}

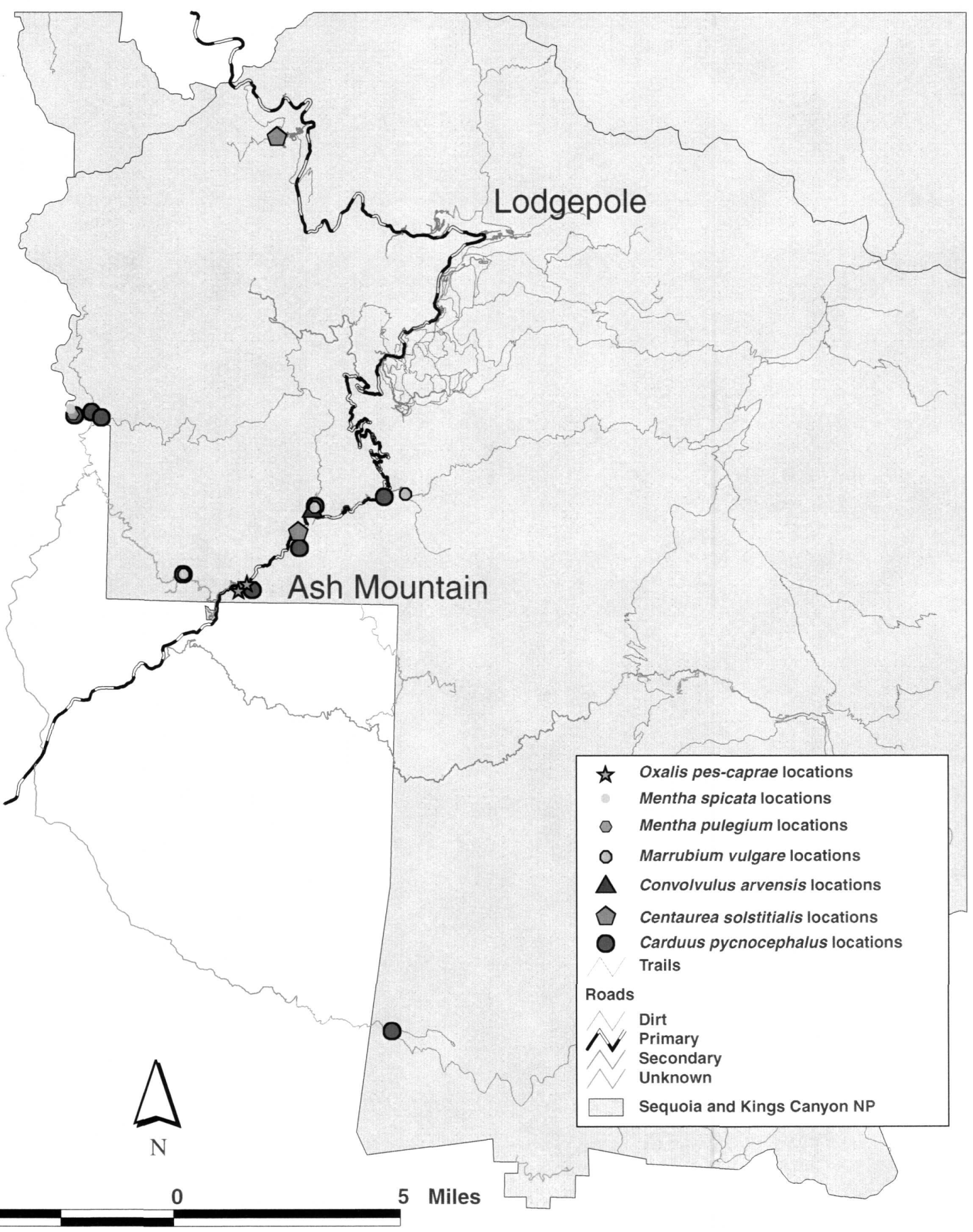

Map 3. Carduus pycnocephalus, Centaurea solstitialis, Convolvulus arvensis, Marrubium vulgare, Mentha pulegium, M. spicata, and Oxalis pes-caprae distributions based on alien plant surveys of disturbed areas in Sequoia and Kings Canyon National Parks, 1996, 1997 and 1998. 


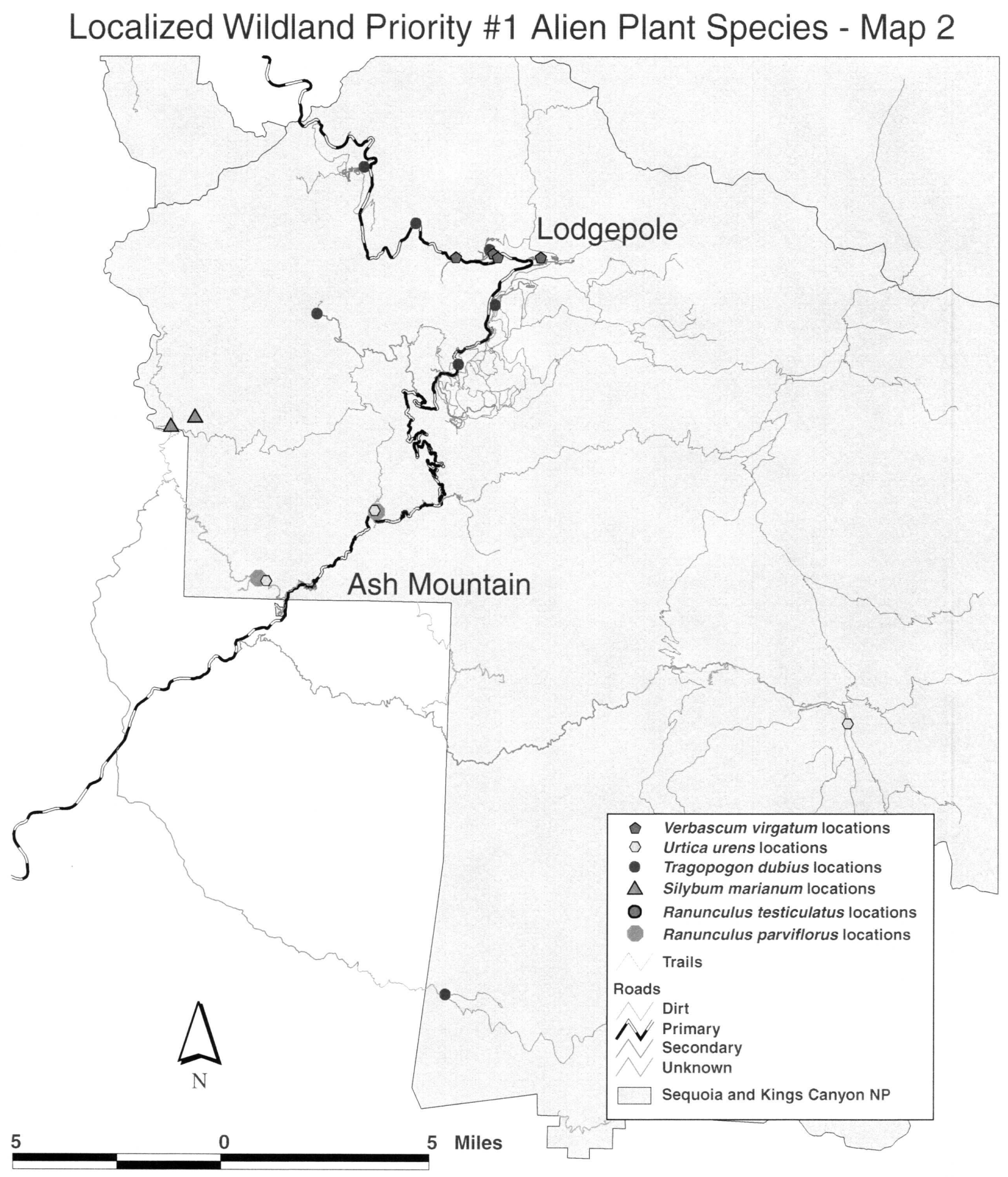

Map 4. Ranunculus parviflorus, R. testiculatus, Silybum marianum, Tragopogon dubius, Urtica urens, and Verbascum virgatum distributions based on alien plant surveys of disturbed areas in Sequoia and Kings Canyon National Parks, 1996, 1997 and 1998. 


\section{Localized Fruit and Nut Priority \#1 Alien Species}

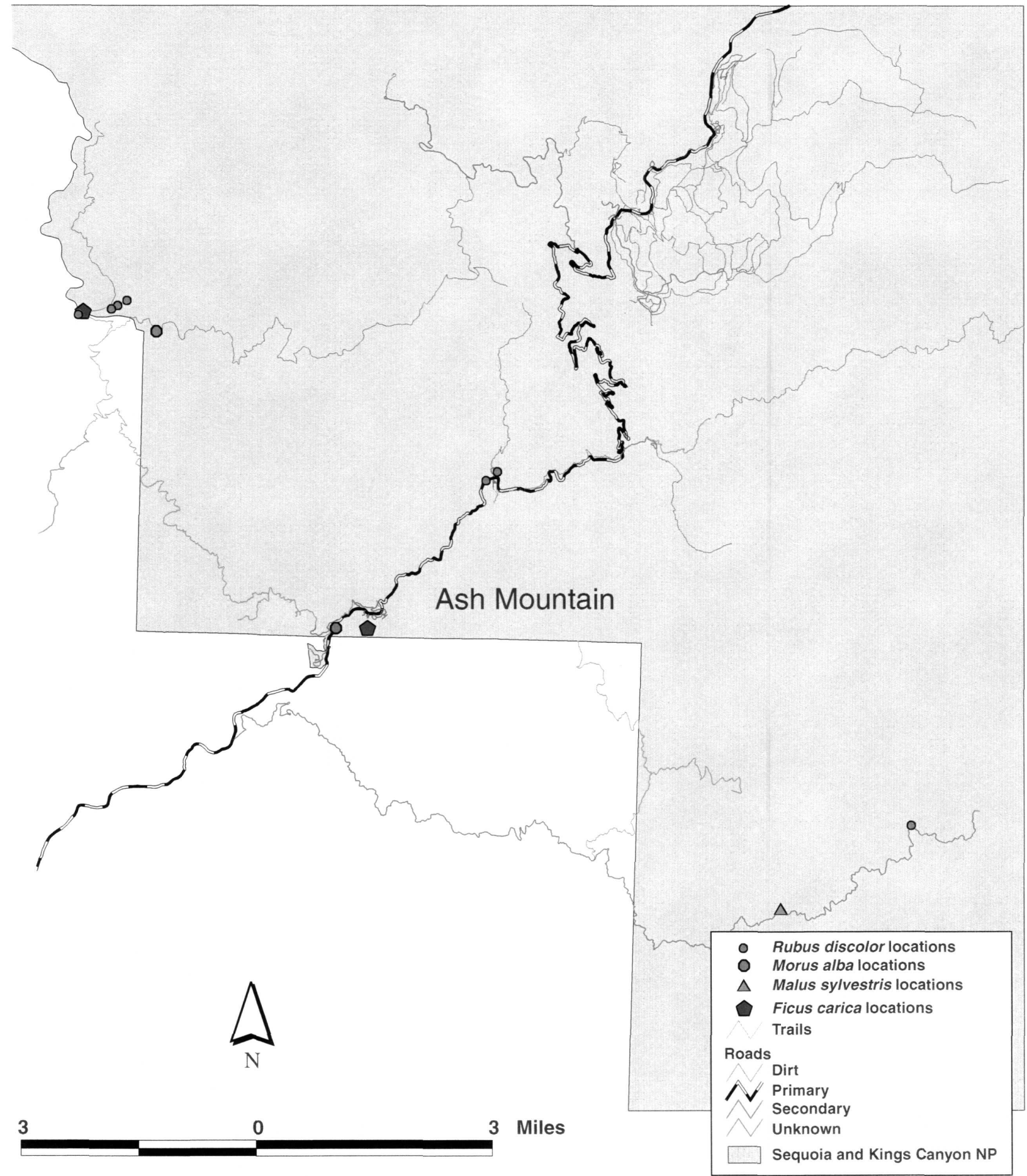

Map 5. Ficus carica, Malus sylvestris, Morus alba, and Rubus discolor distributions based on alien plant surveys of disturbed areas in Sequoia and Kings Canyon National Parks, 1996, 1997 and 1998. 


\section{Localized Fruit and Nut Priority \#2 Alien Species}

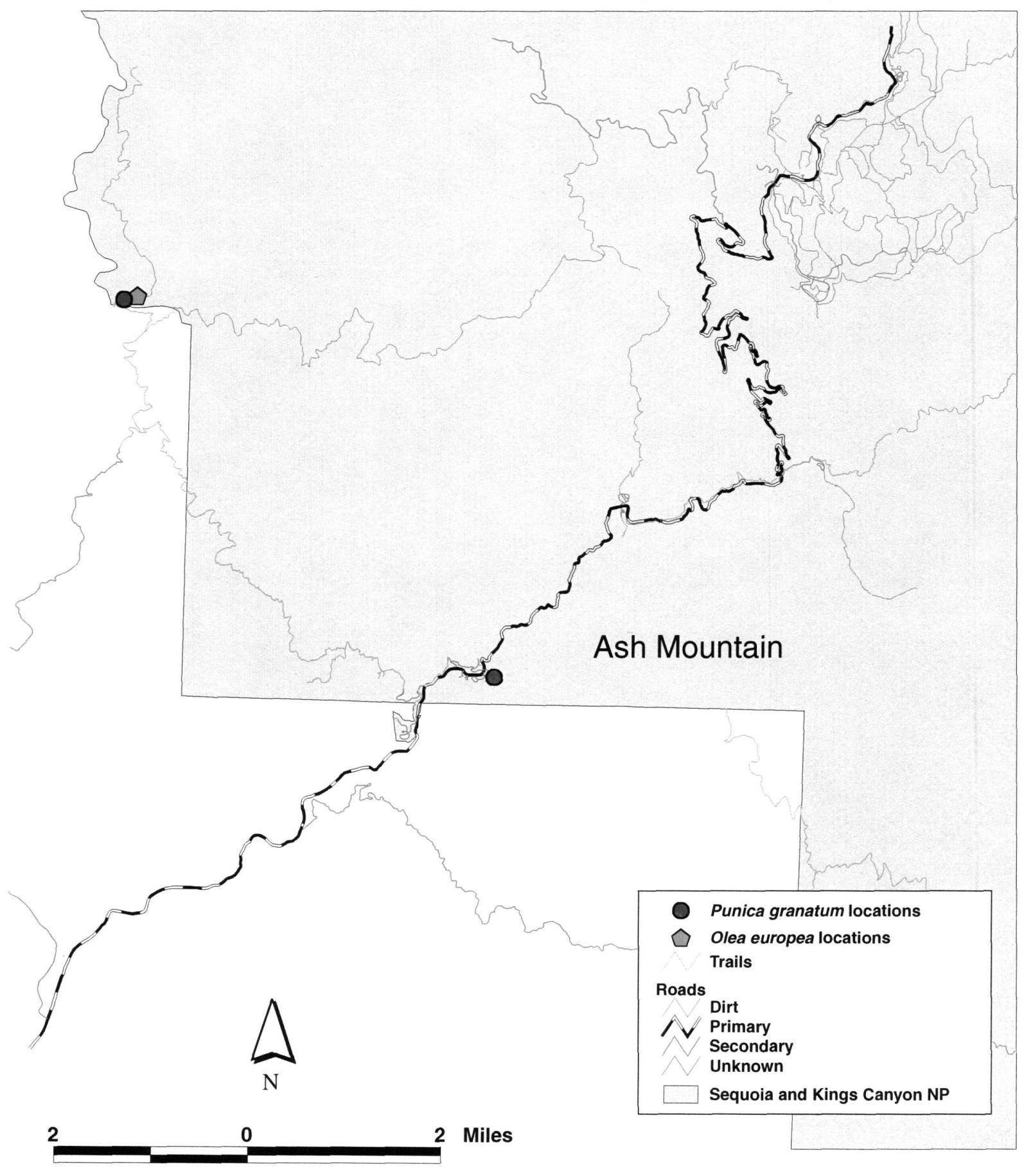

Map 6. Olea europea and Punica granatum distributions based on alien plant surveys of disturbed areas in Sequoia and Kings Canyon National Parks, 1996, 1997 and 1998. 


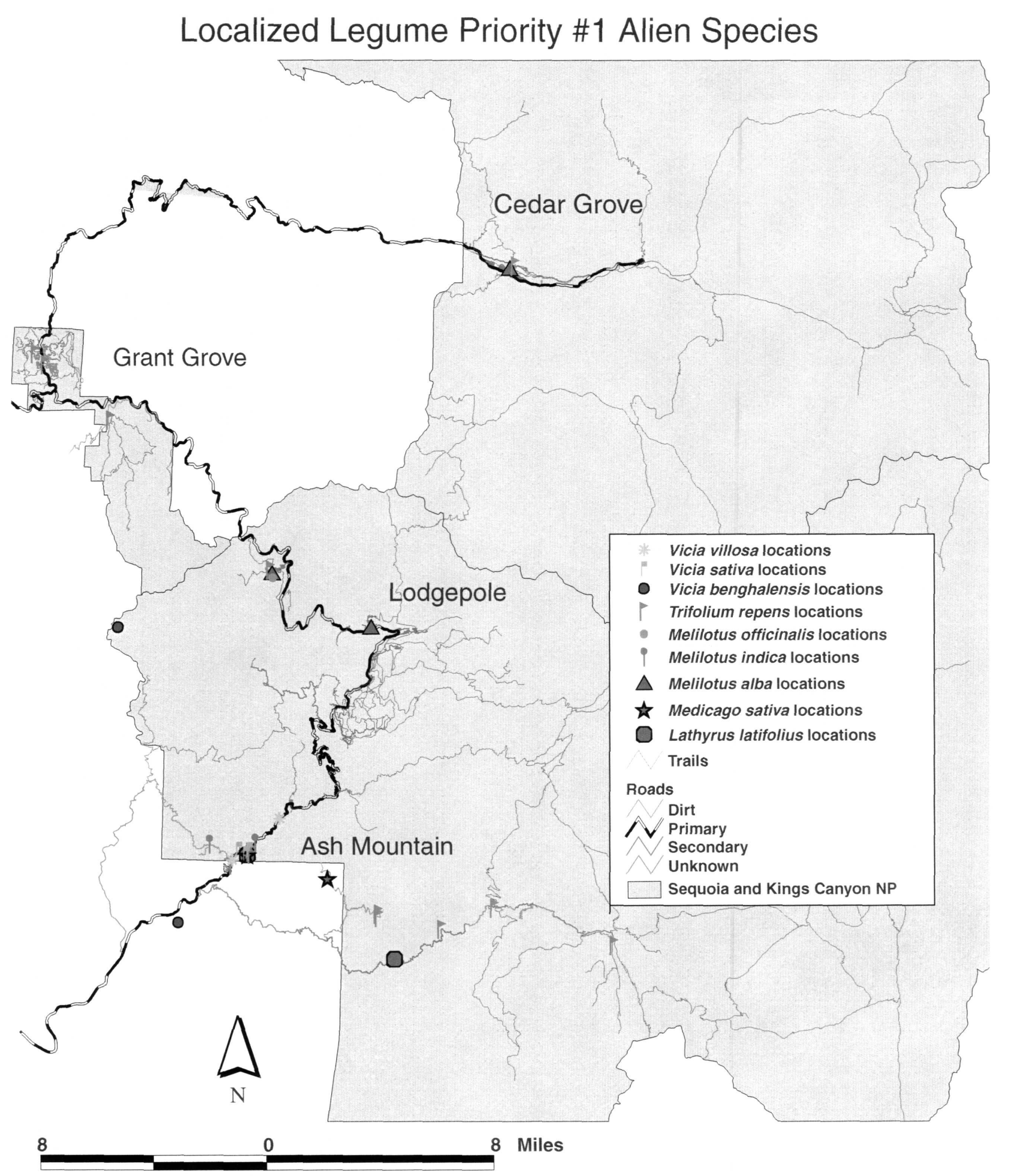

Map 7. Lathyrus latifolius, Medicago sativa, Melilotus alba, M. indica, M. officinalis, Trifolium repens, Vicia benghalensis, $V$. sativa, and $V$. villosa distributions based on alien plant surveys of disturbed areas in Sequoia and Kings Canyon National Parks, 1996, 1997 and 1998. 


\section{Localized Ornamental Priority \#1 Alien Species - Map 1}

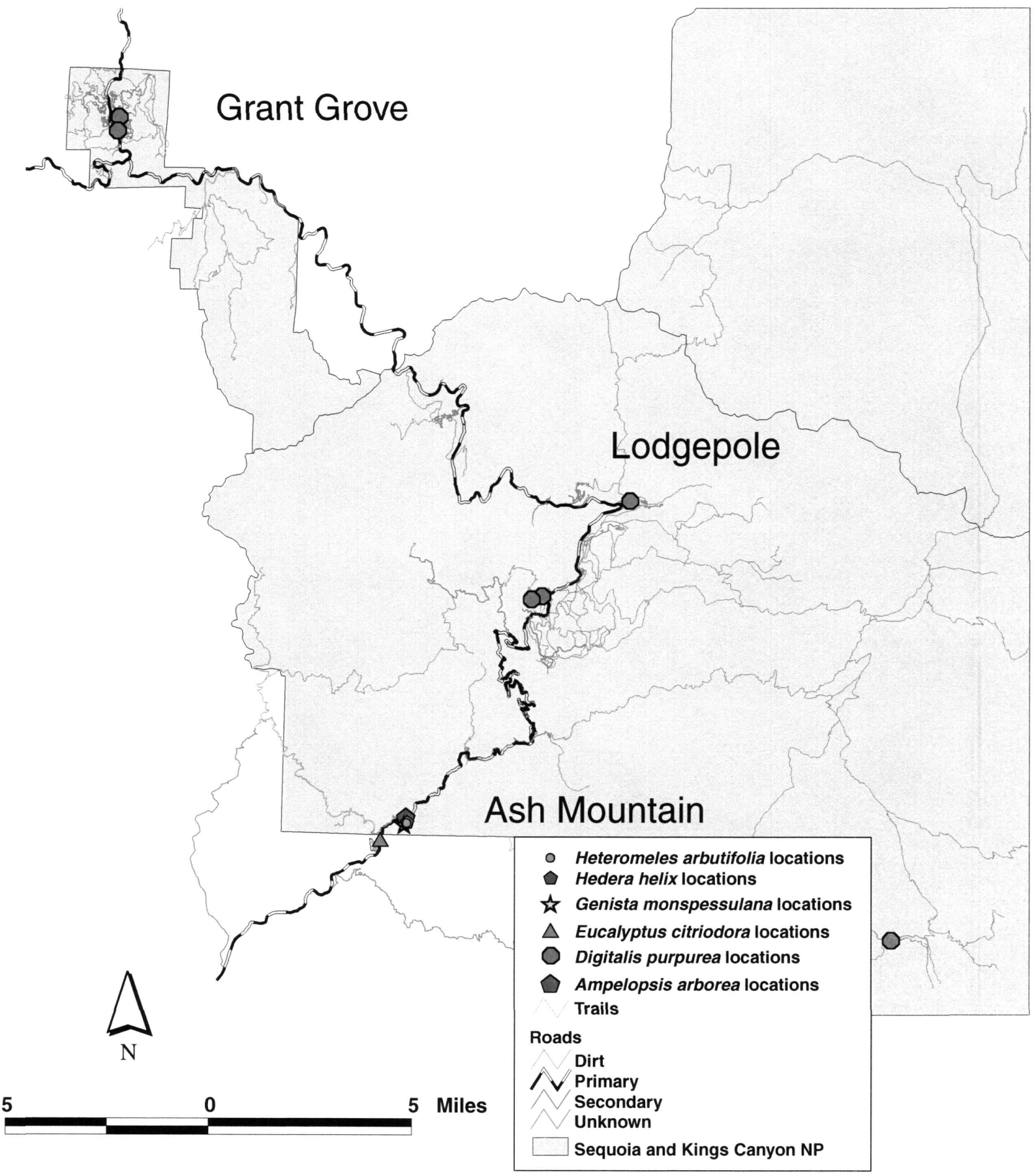

Map 8. Ampelopsis arborea, Digitalis purpurea, Eucalyptus citriodora, Genista monspessulana, Hedera helix, and Heteromeles arbutifolia distributions based on alien plant surveys of disturbed areas in Sequoia and Kings Canyon National Parks, 1996, 1997 and 1998. 


\section{Localized Ornamental Priority \#1 Exotic Species - Map 2}

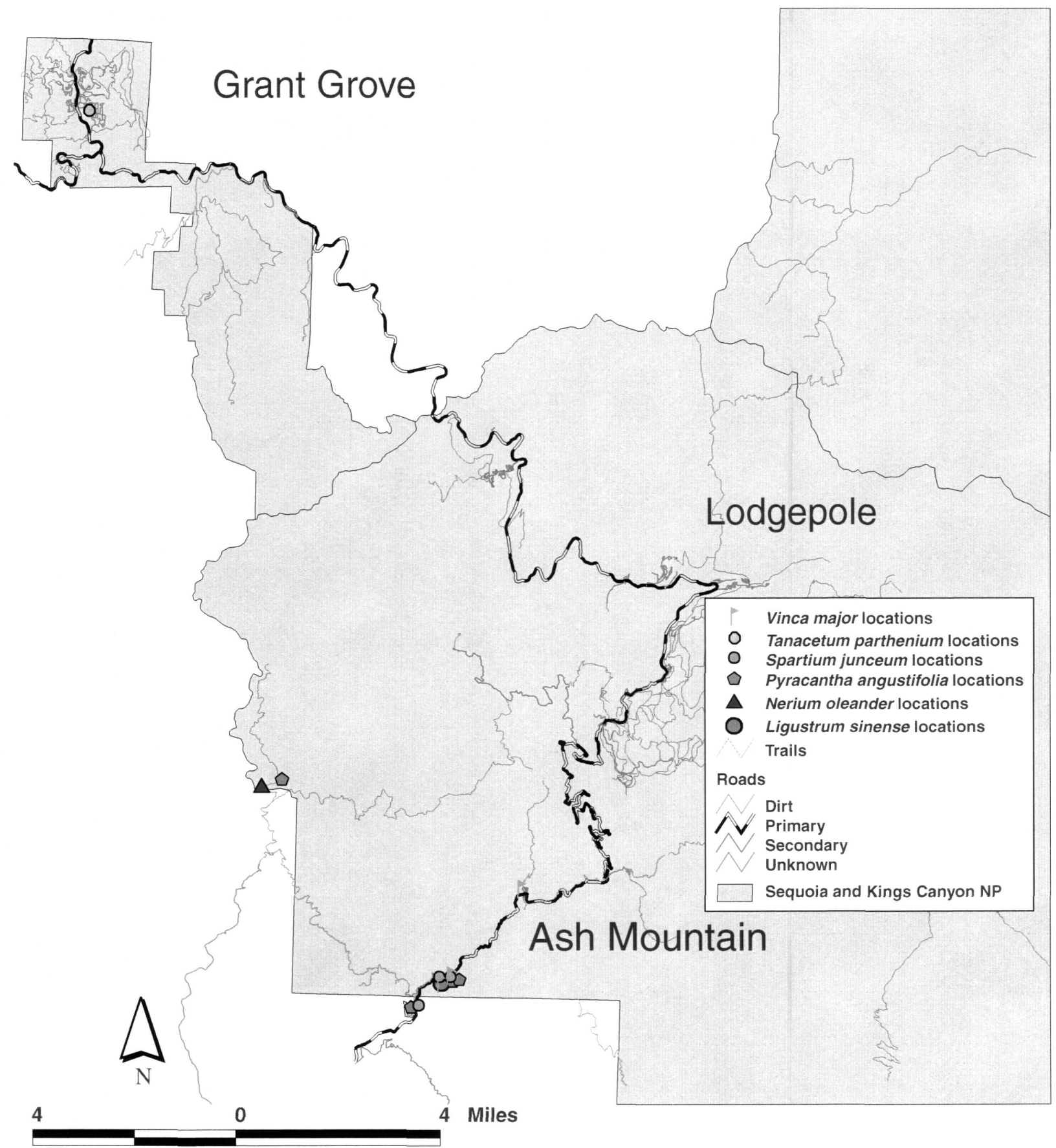

Map 9. Ligustrum sinense, Nerium oleander, Pyracantha angustifolia, Spartium junceum, Tanacetum parthenium, and Vinca major distributions based on alien plant surveys of disturbed areas in Sequoia and Kings Canyon National Parks, 1996, 1997 and 1998. 


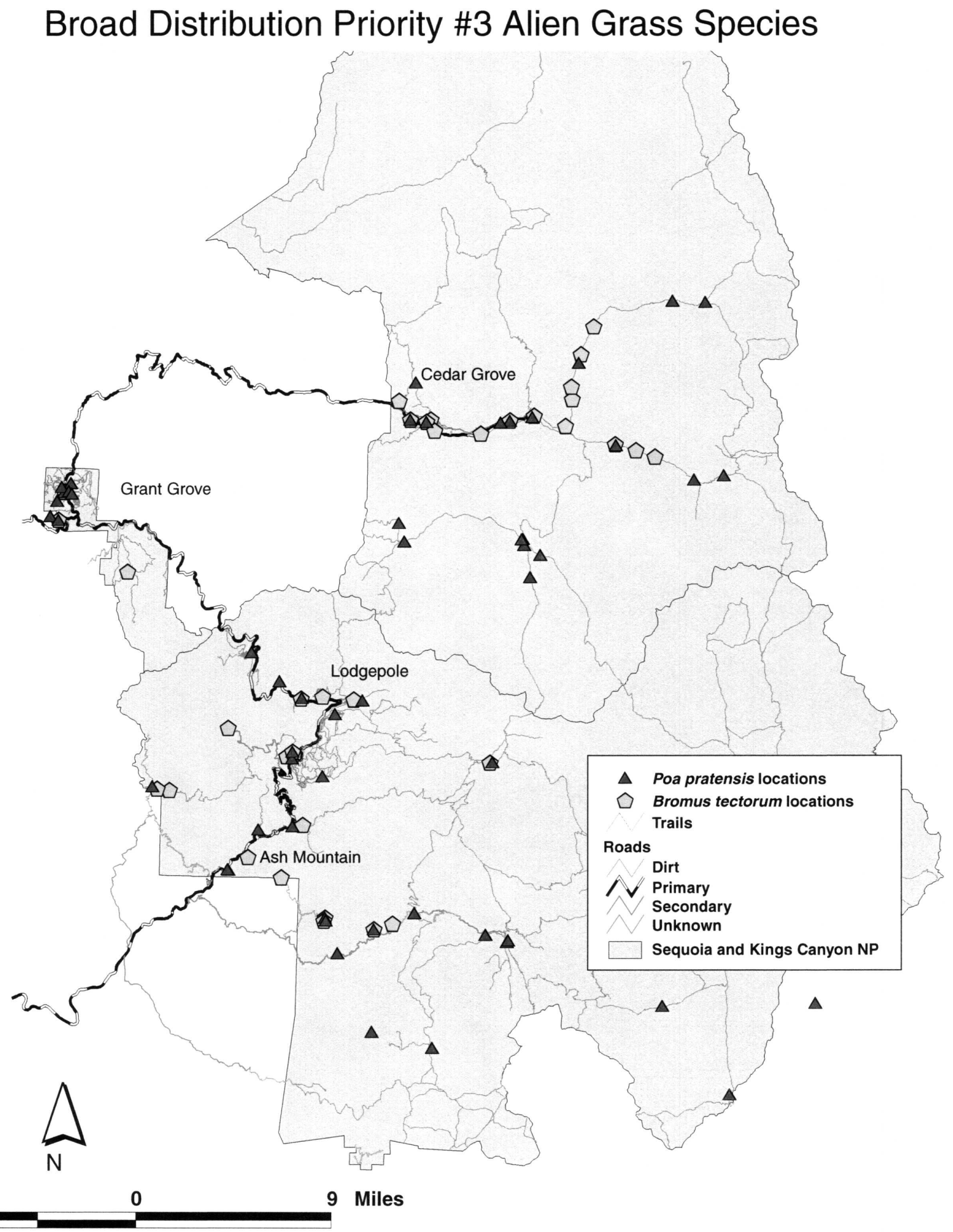

Map 10. Poa pratensis and Bromus tectorum distributions based on alien plant surveys of disturbed areas in Sequoia and Kings Canyon National Parks, 1996, 1997 and 1998. 


\section{Localized Wildland Priority \#1 Alien Grass Species}

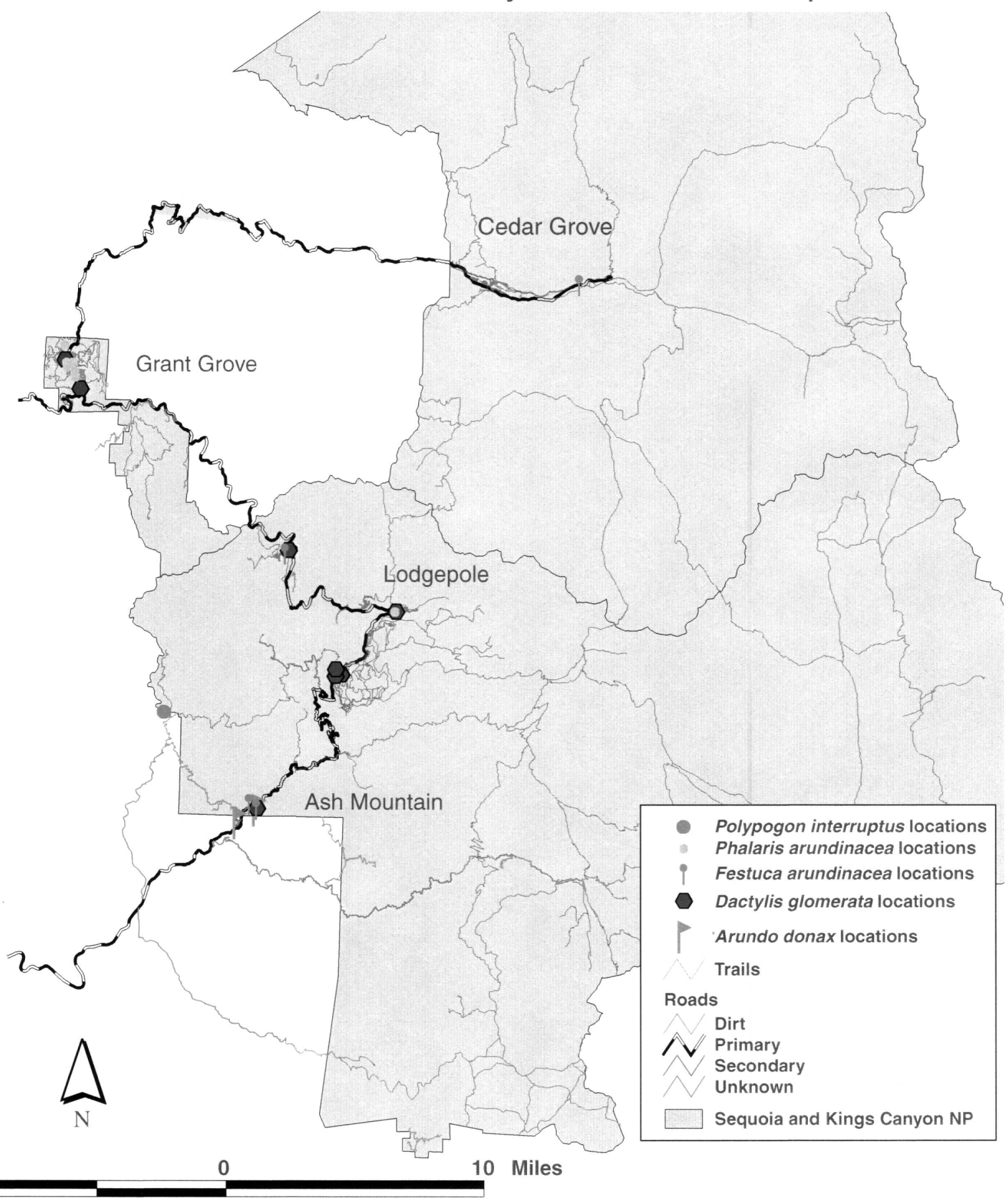

Map 11. Arundo donax, Dactylils glomerata, Festuca arundinacea, Phalaris arundinacea, and Polypogon interruptus distributions based on alien plant surveys of disturbed areas in Sequoia and Kings Canyon National Parks, 1996, 1997 and 1998. 


\section{Localized Wildland Priority \#2 Alien Grass Species - Map 1}

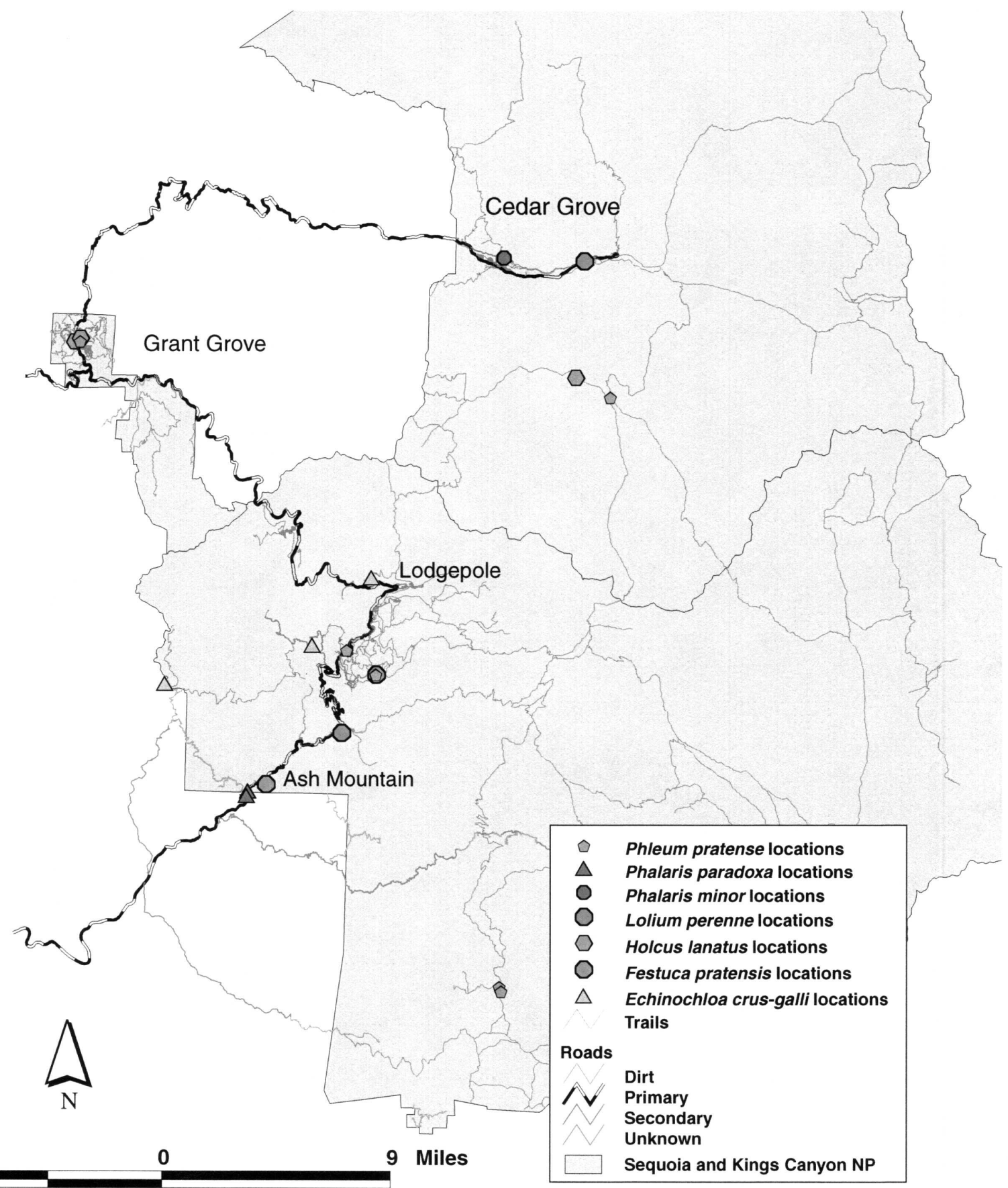

Map 12. Echinochloa crus-galli, Festuca pratensis, Holcus lanatus, Lolium perenne, Phalaris minor, P. paradoxa, and Phleum pratense distributions based on alien plant surveys of disturbed areas in Sequoia and Kings Canyon National Parks, 1996, 1997 and 1998. 


\section{Localized Wildland Priority \#2 Alien Grass Species - Map 2}

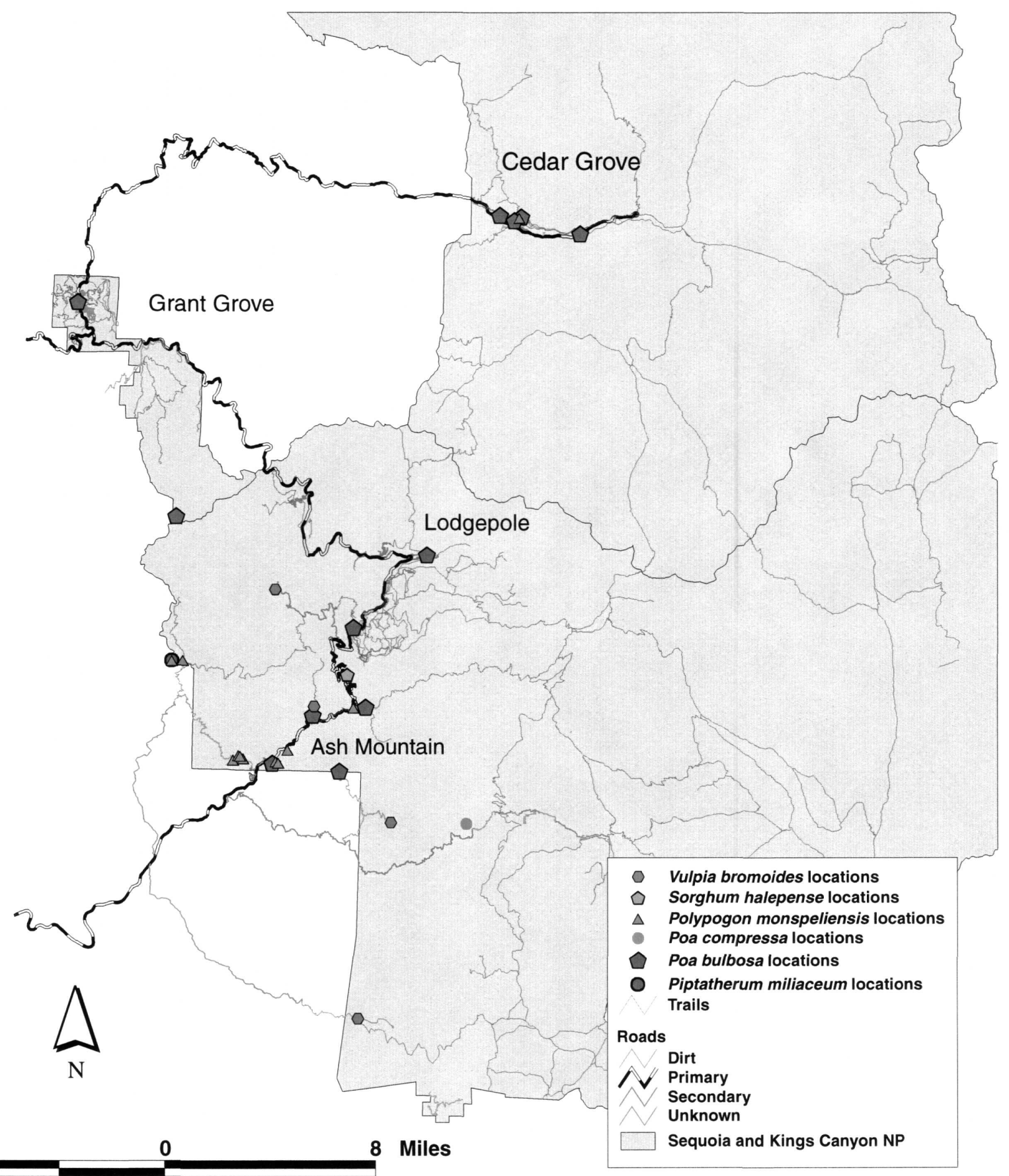

Map 13. Piptatherum miliaceum, Poa bulbosa, P. compressa, Polypogon monspeliensis, Sorghum halepense, and Vulpia bromoides distributions based on alien plant surveys of disturbed areas in Sequoia and Kings Canyon National Parks, 1996, 1997 and 1998. 


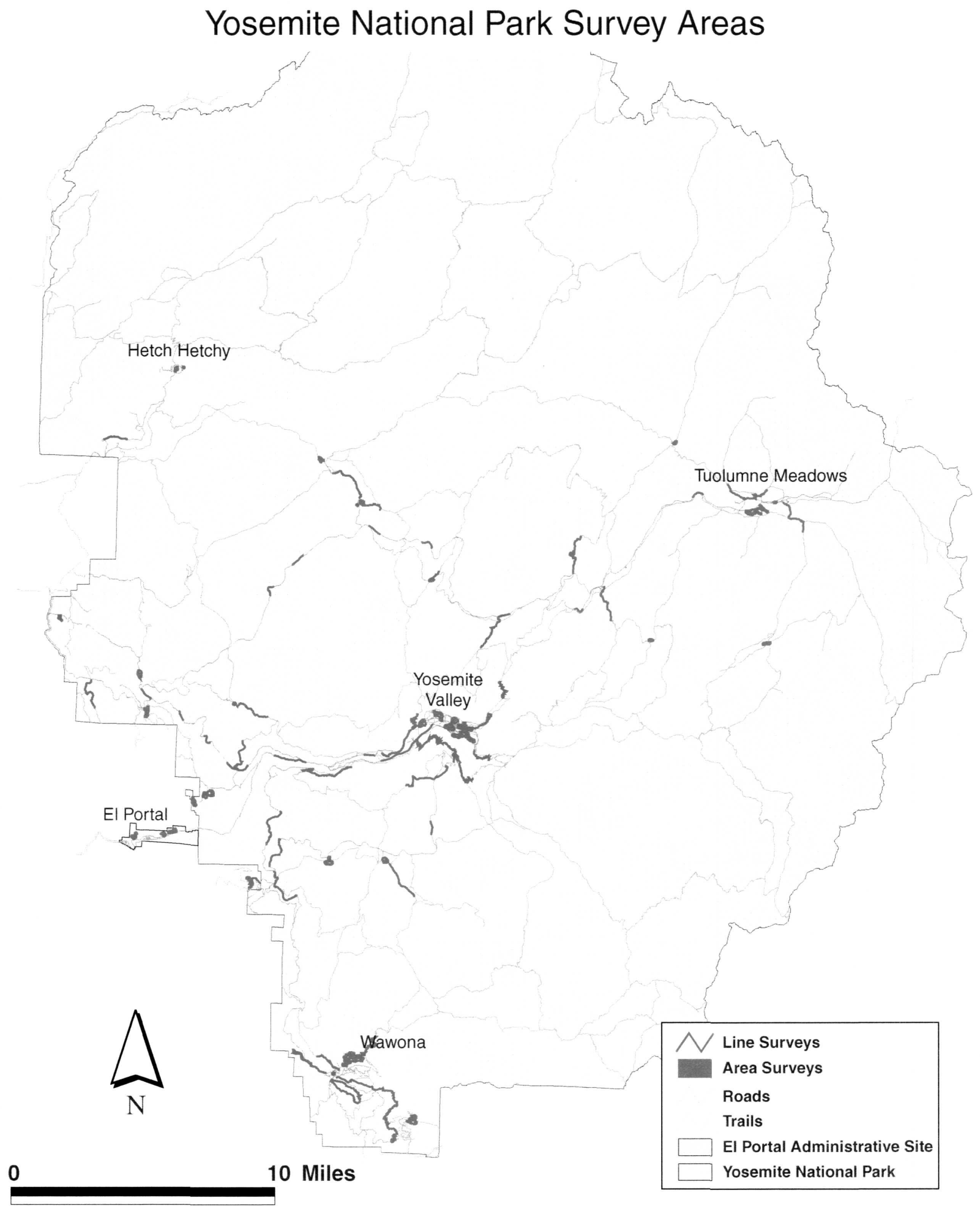

Map 14. Alien plant surveys of disturbed areas in Yosemite National Park, 1998 and 1999. 


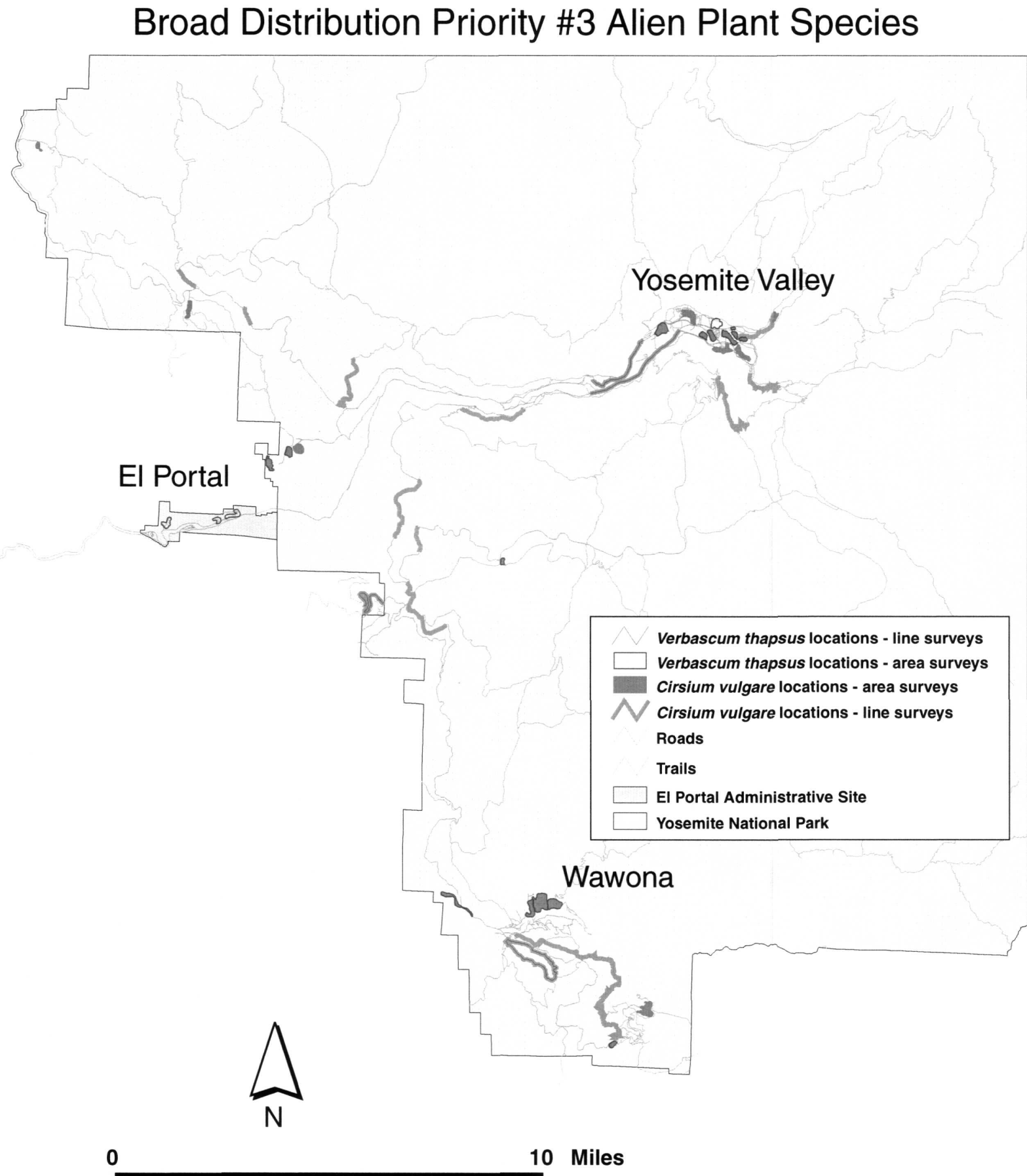

Map 15. Cirsium vulgare and Verbascum thapsus distributions based on alien plant surveys of disturbed areas in Yosemite National Park, 1998 and 1999. 


\section{Localized Wildland Priority \#1 Alien Plant Species - Map 1}

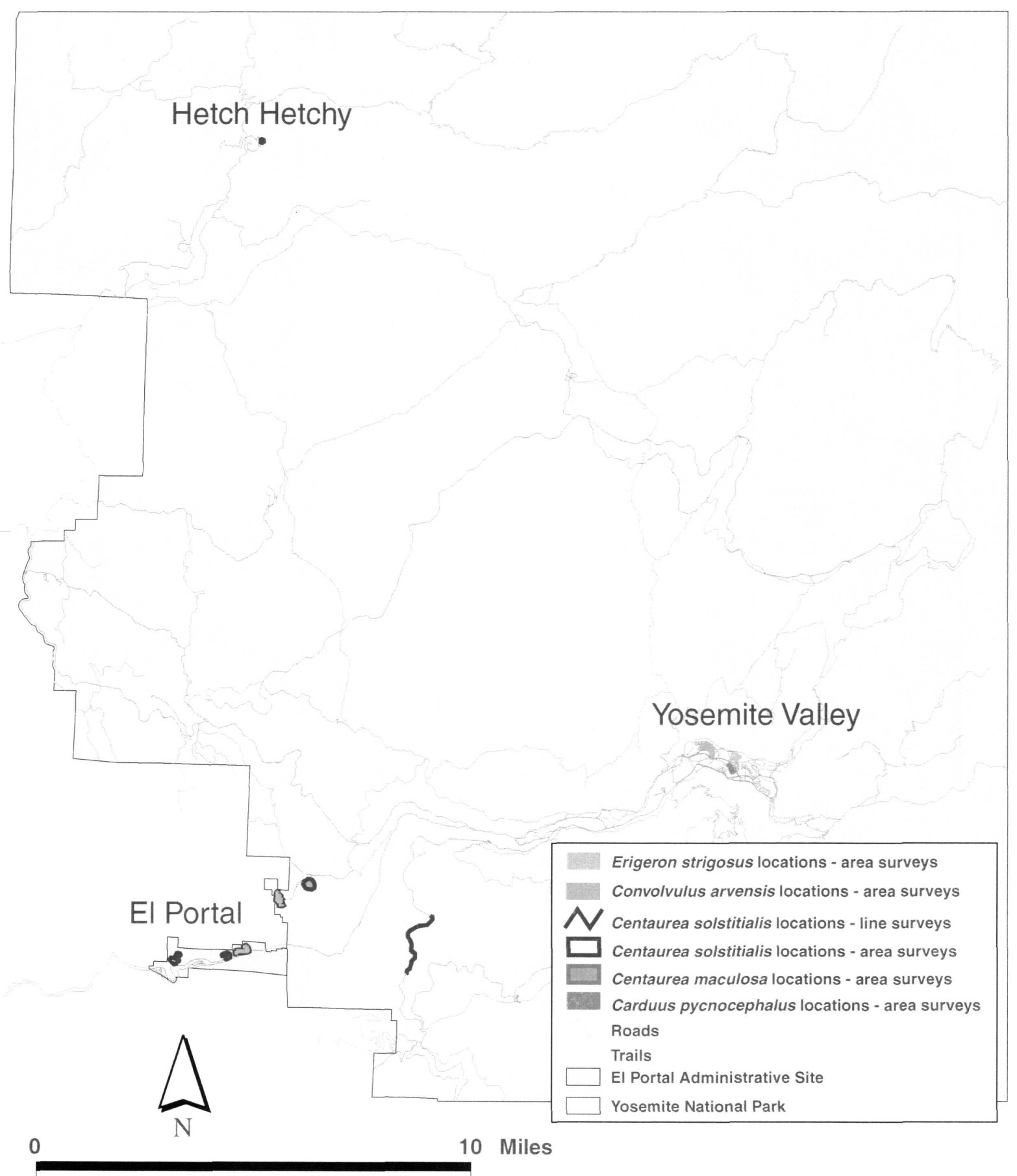

Map 16. Carduus pycnocephalus, Centaurea maculosa, C. solstitialis, Convolvulus arvensis, and Erigeron strigosus distributions based on alien plant surveys of disturbed areas in Yosemite National Park, 1998 and 1999. 


\section{Localized Wildland Priority \#1 Alien Plant Species - Map 2}

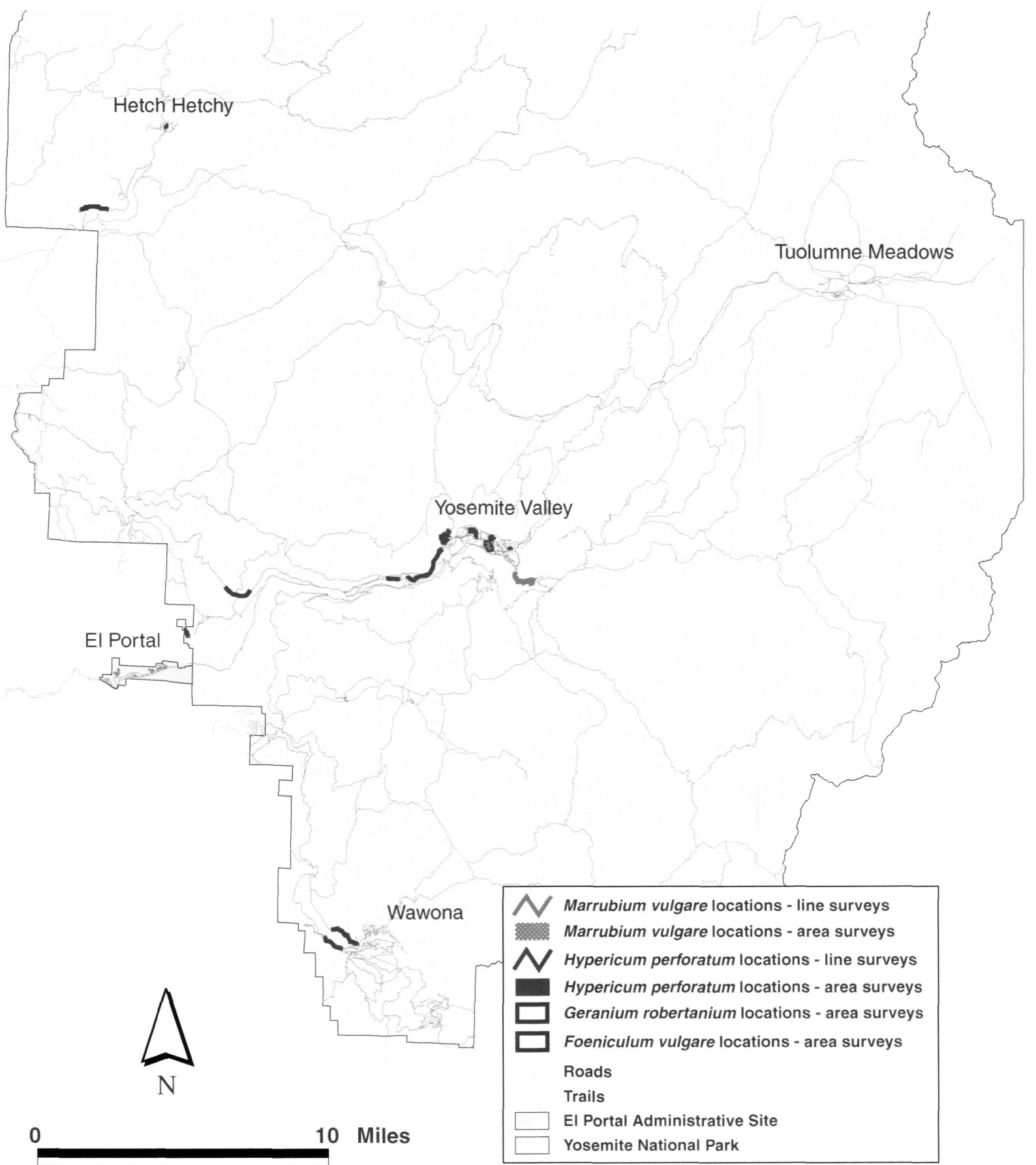

Map 17. Foeniculum vulgare, Geranium robertanium, Hypericum perforatum, and Marrubium vulgare distributions based on alien plant surveys of disturbed areas in Yosemite National Park, 1998 and 1999. 


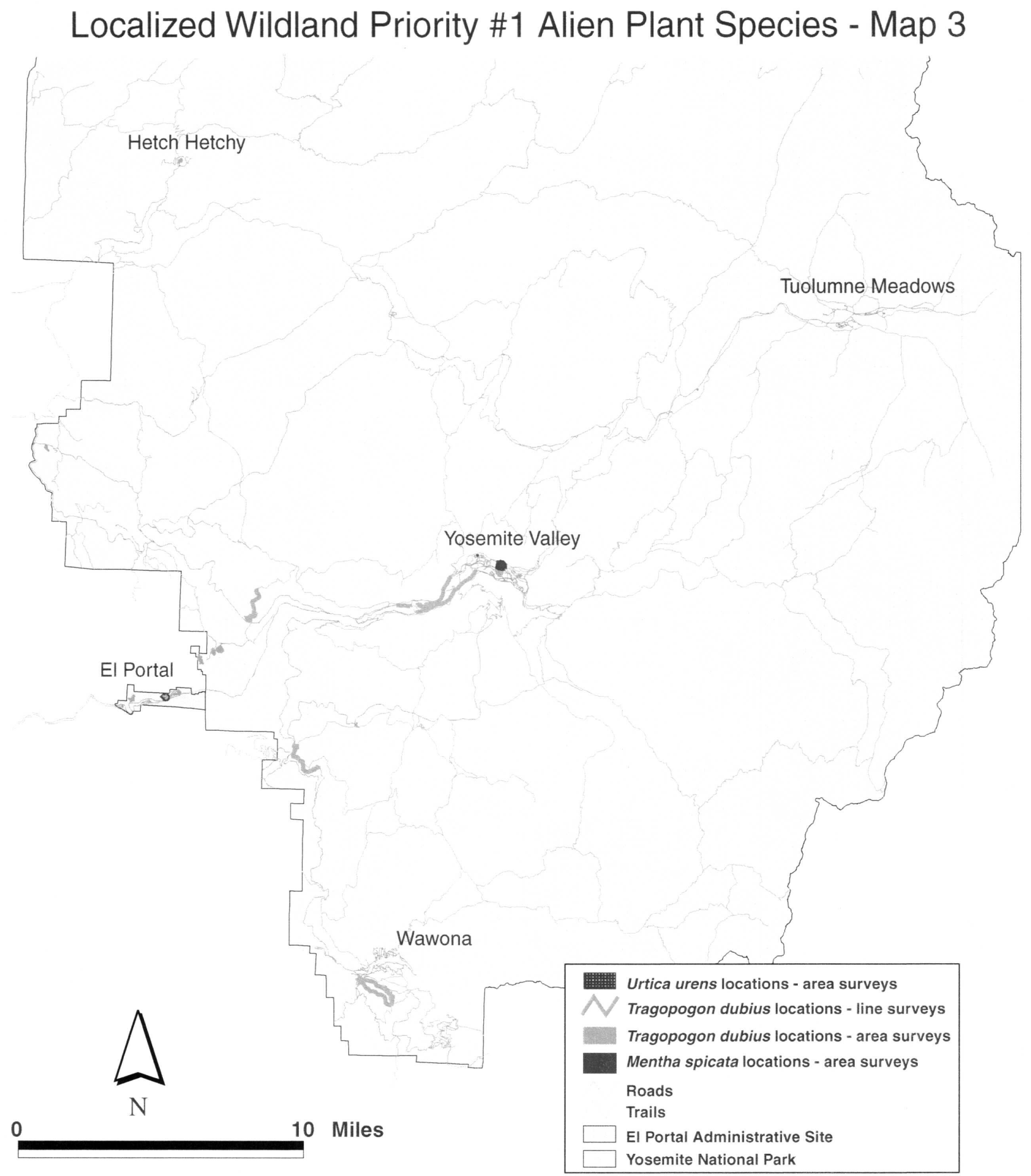

Map 18. Mentha spicata, Tragopogon dubius, and Urtica urens distributions based on alien plant surveys of disturbed areas in Yosemite National Park, 1998 and 1999. 


\section{Localized Wildland Priority \#1 Alien Legume Species - Map 1}

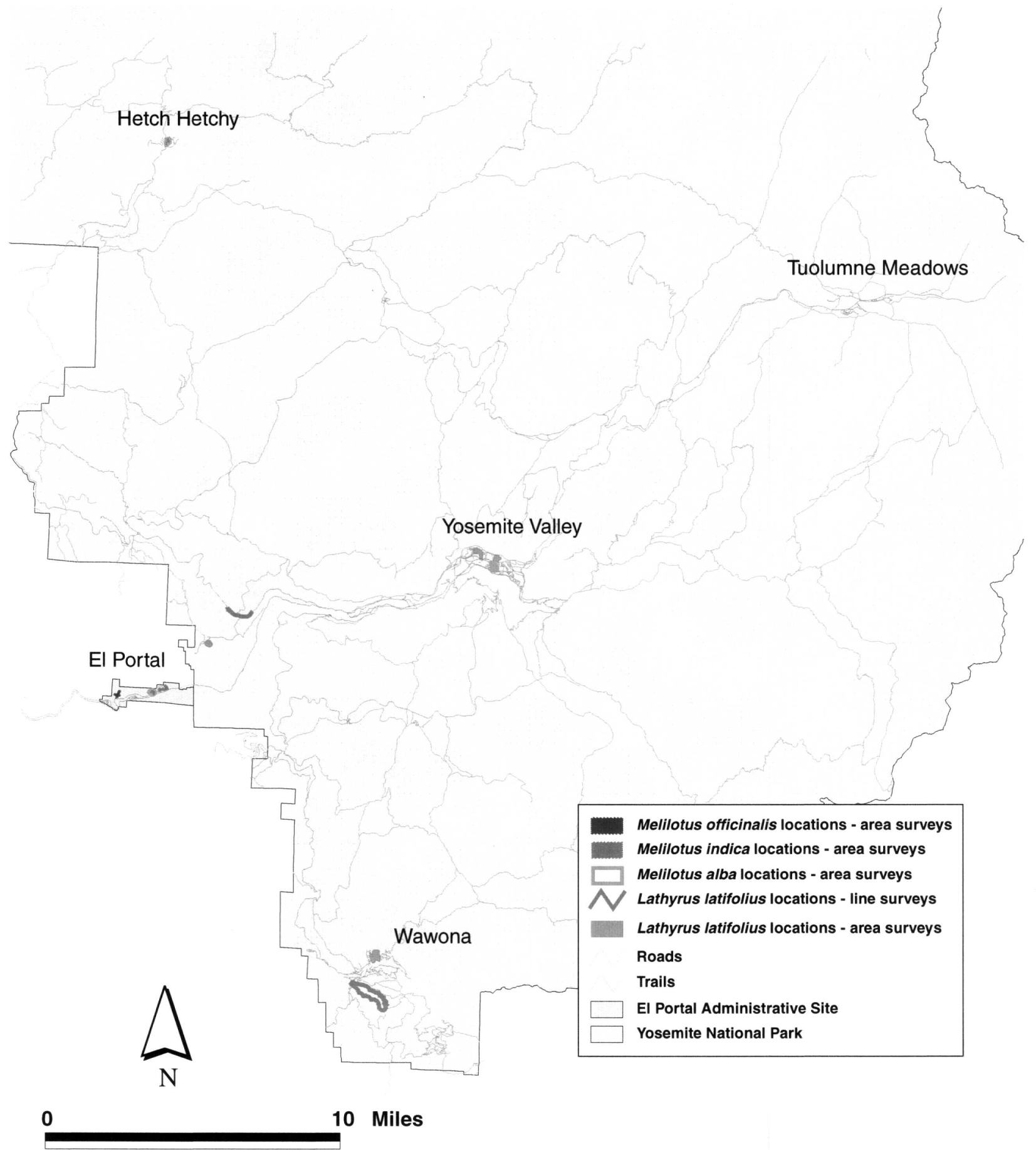

Map 19. Lathyrus latifolius, Melilotus alba, M. indica, and $M$. officinalis distributions based on alien plant surveys of disturbed areas in Yosemite National Park, 1998 and 1999. 


\section{Localized Wildland Priority \#1 Alien Legume Species - Map 2}

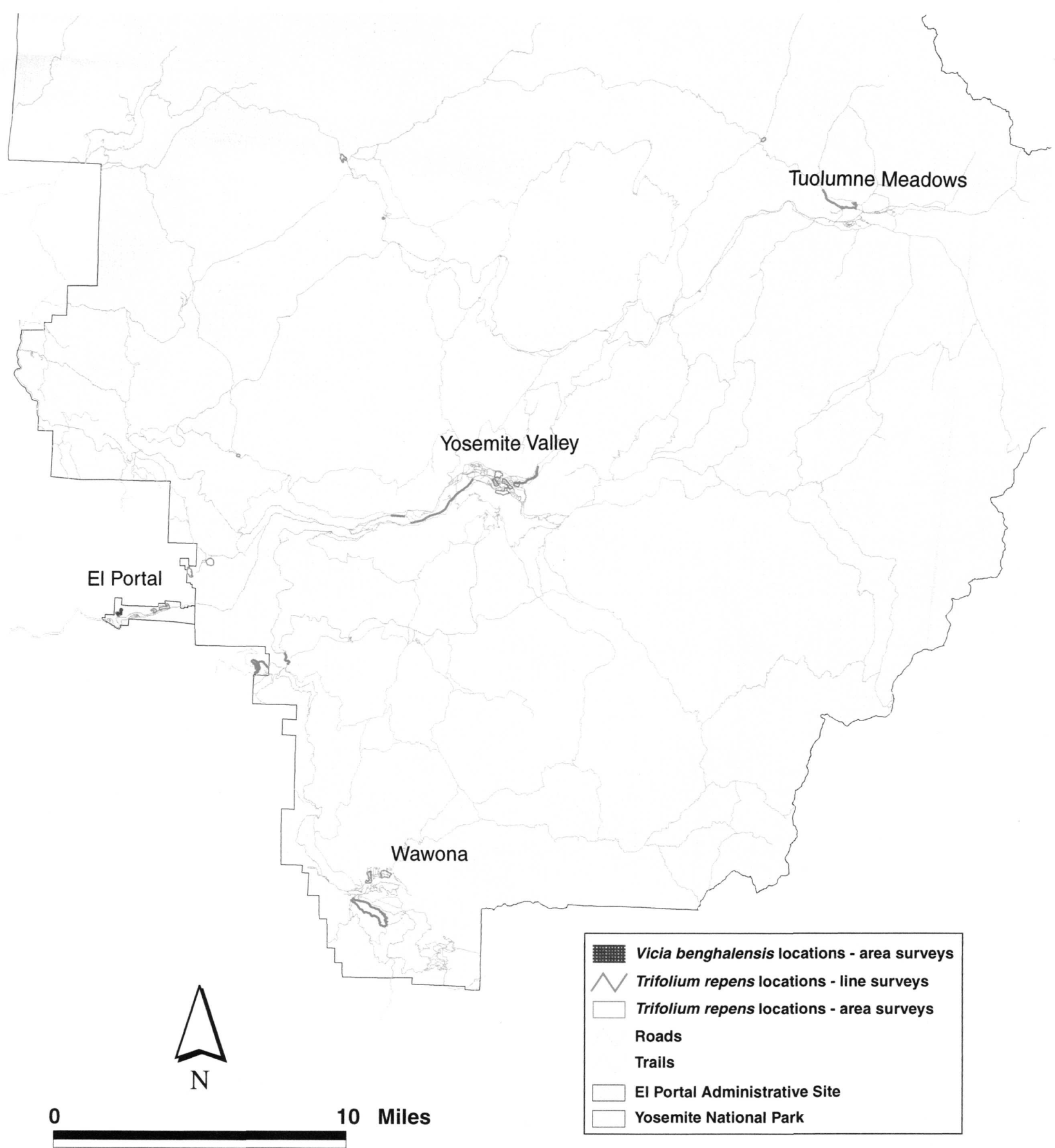

Map 20. Trifolium repens and Vicia benghalensis distributions based on alien plant surveys of disturbed areas in Yosemite National Park, 1998 and 1999. 


\section{Localized Fruit Priority \#1 Alien Species}

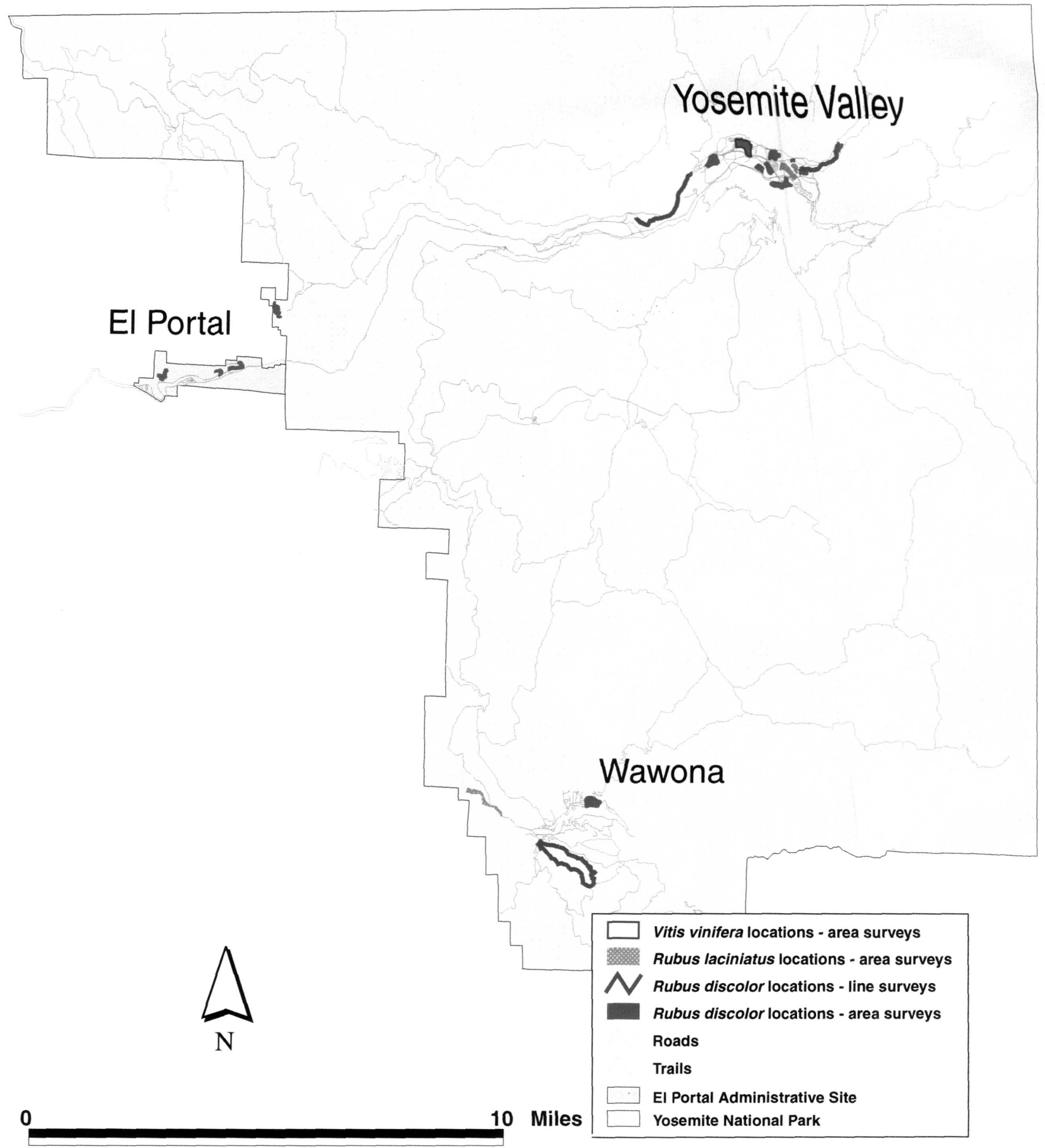

Map 21. Rubus discolor, $R$. laciniatus, and Vitis vinifera distributions based on alien plant surveys of disturbed areas in Yosemite National Park, 1998 and 1999. 


\section{Localized Ornamental Priority \#1 Alien Species - Map 1}

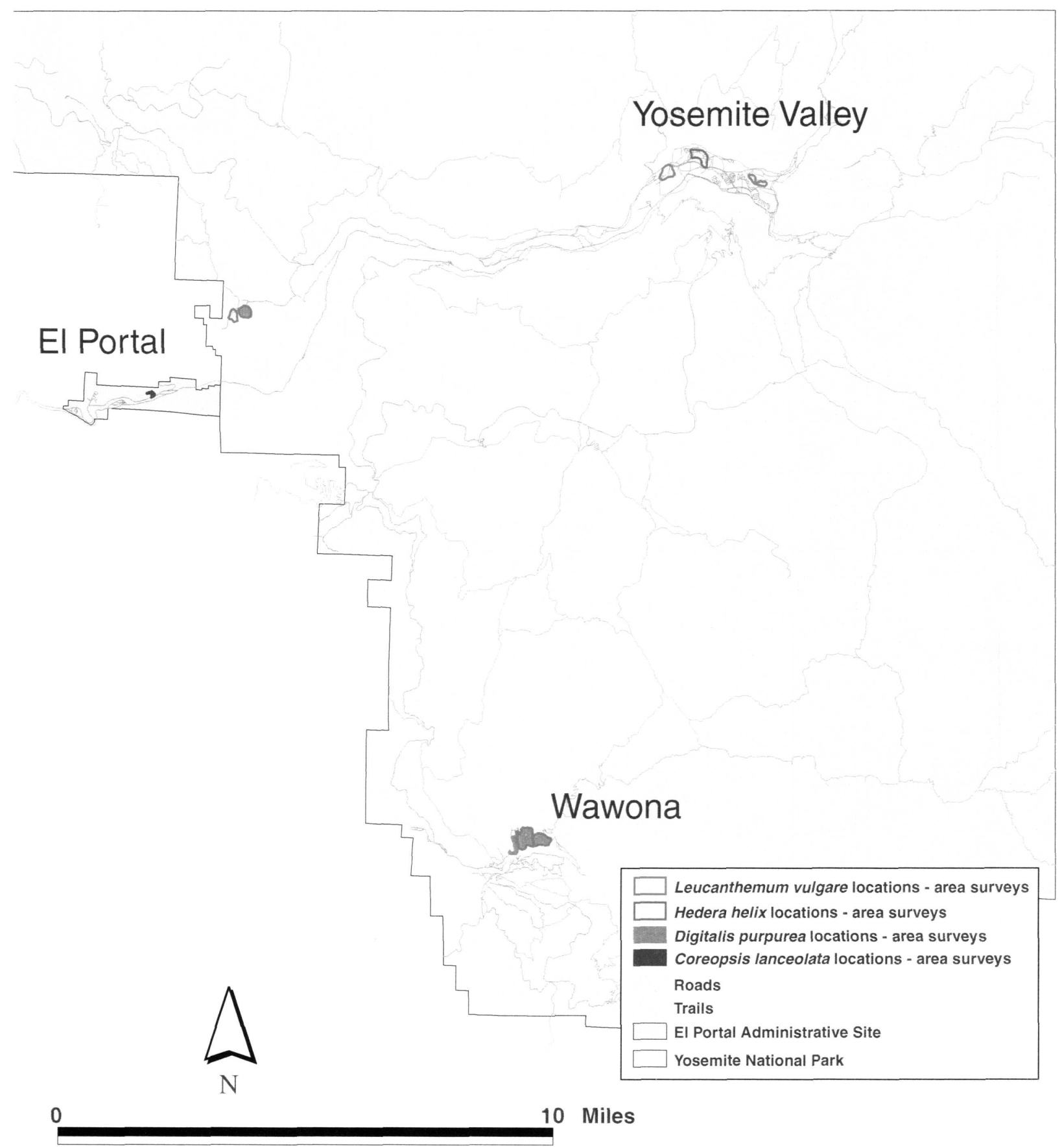

Map 22. Coreopsis lanceolata, Digitalis purpurea, Hedera helix, and Leucanthemum vulgare distribution based on alien plant surveys of disturbed areas in Yosemite National Park, 1998 and 1999. 


\section{Localized Ornamental Priority \#1 Alien Species - Map 2}

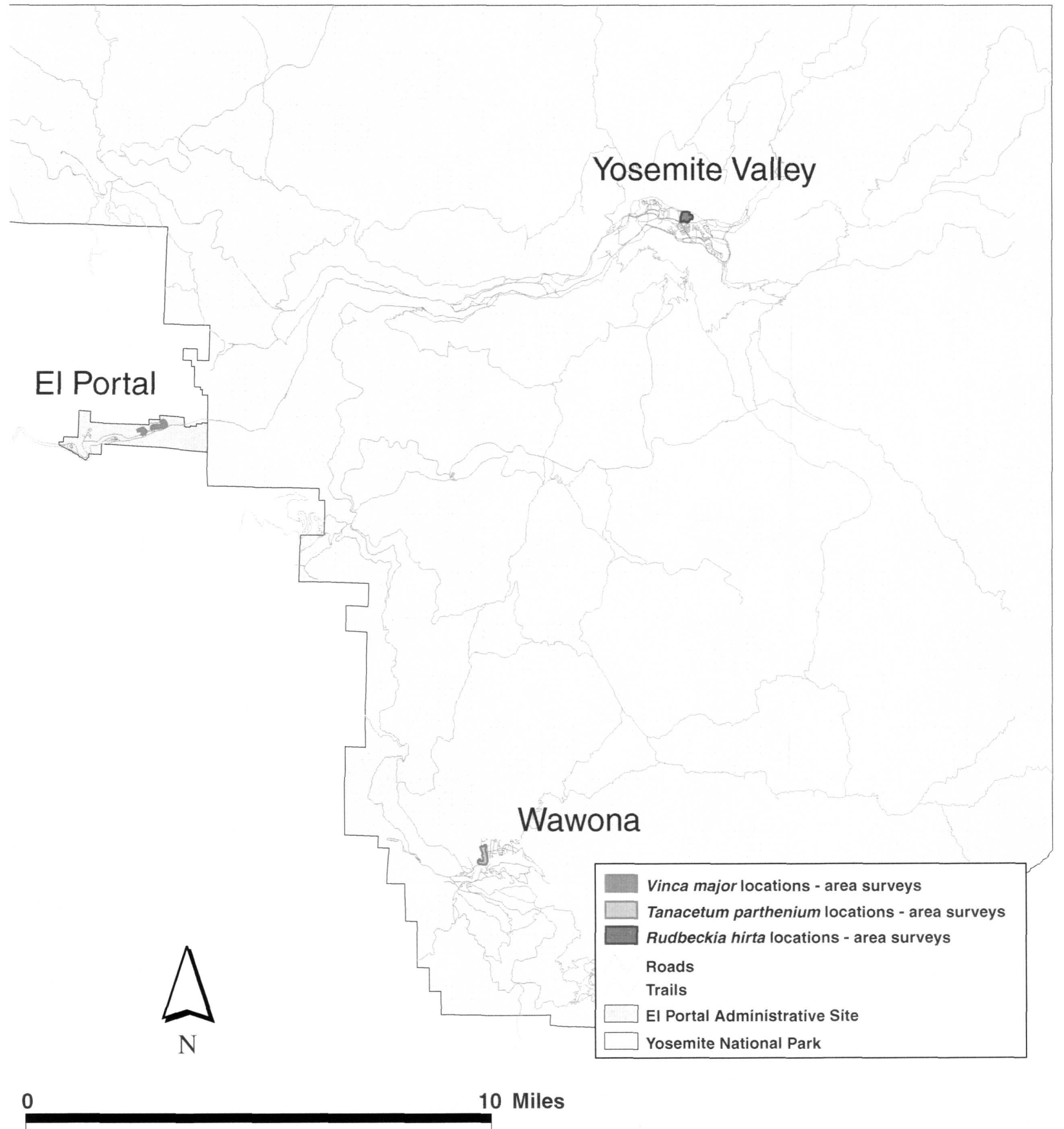

Map 23. Rudbeckia hirta, Tanacetum parthenium, and Vinca major distributions based on alien plant surveys of disturbed areas in Yosemite National Park, 1998 and 1999. 


\section{Broad Distribution Priority \#3 Alien Grass Species}

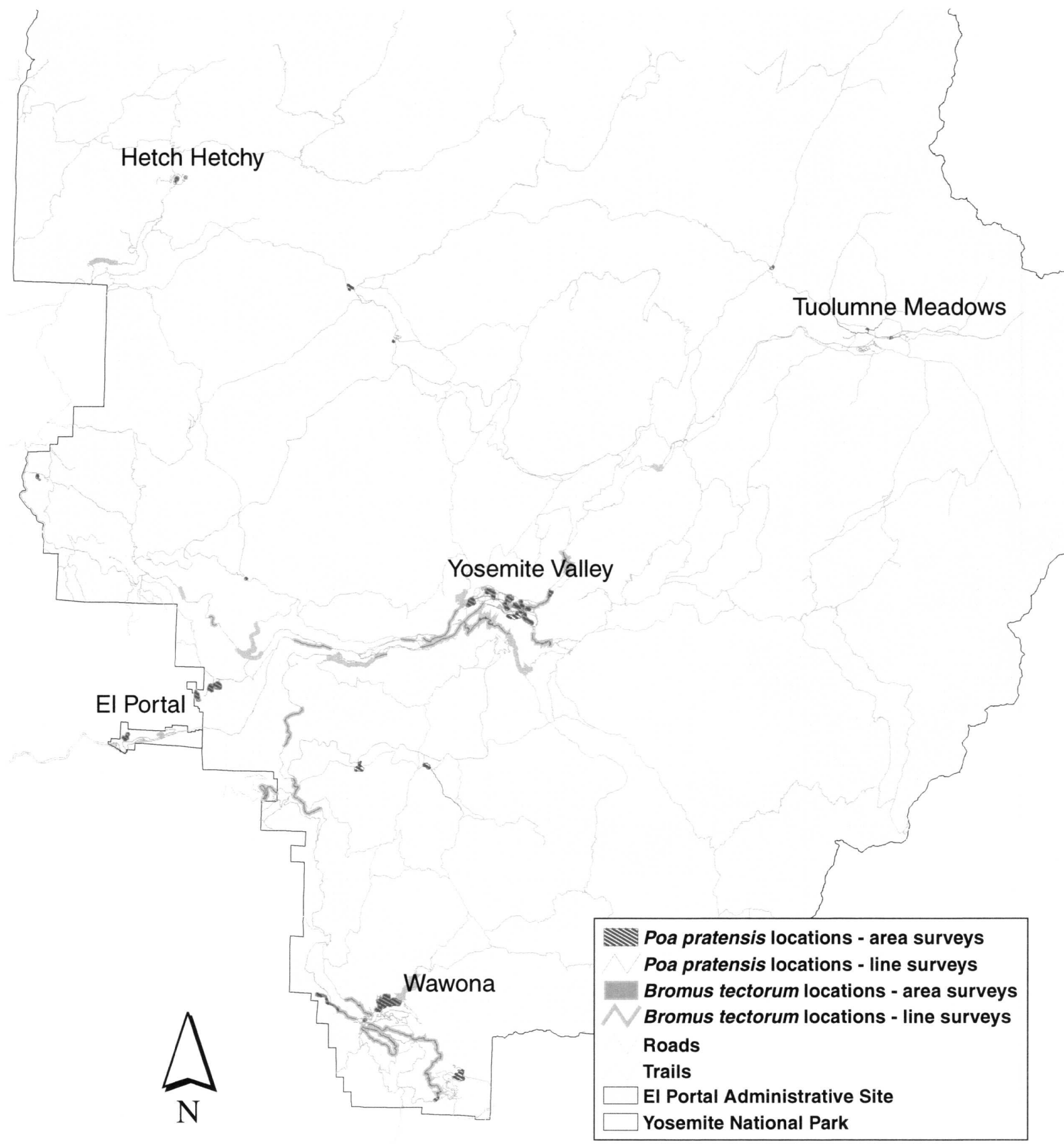

0 10 Miles

Map 24. Bromus tectorum and Poa prantensis distributions based on alien plant surveys of disturbed areas in Yosemite National Park, 1998 and 1999. 


\section{Localized Wildland Priority \#1 Alien Grass Species - Map 1}

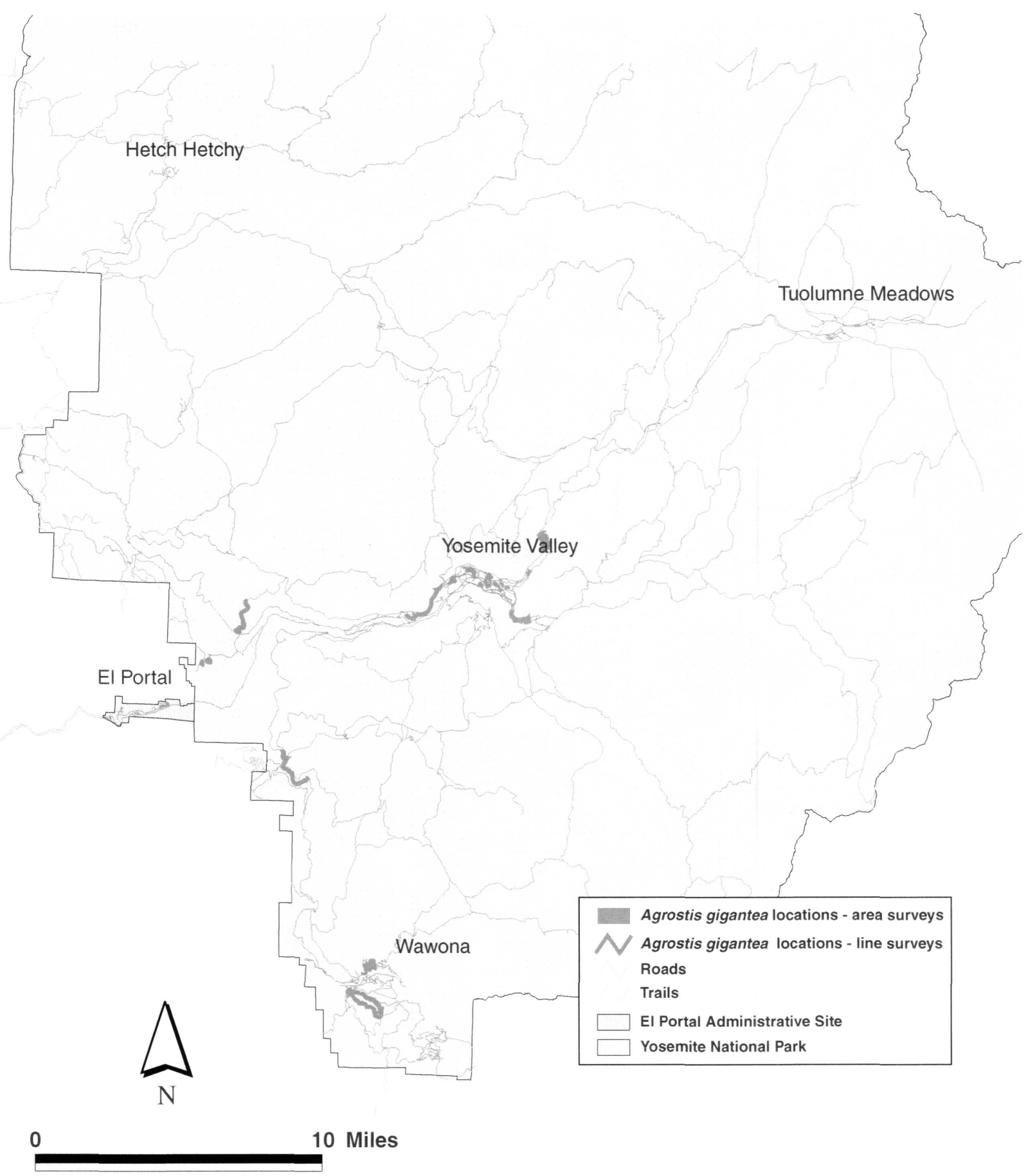

Map 25. Agrostis gigantea distribution based on alien plant surveys of disturbed areas in Yosemite National Park, 1998 and 1999. 


\section{Localized Wildland Priority \#1 Alien Grass Species - Map 2}

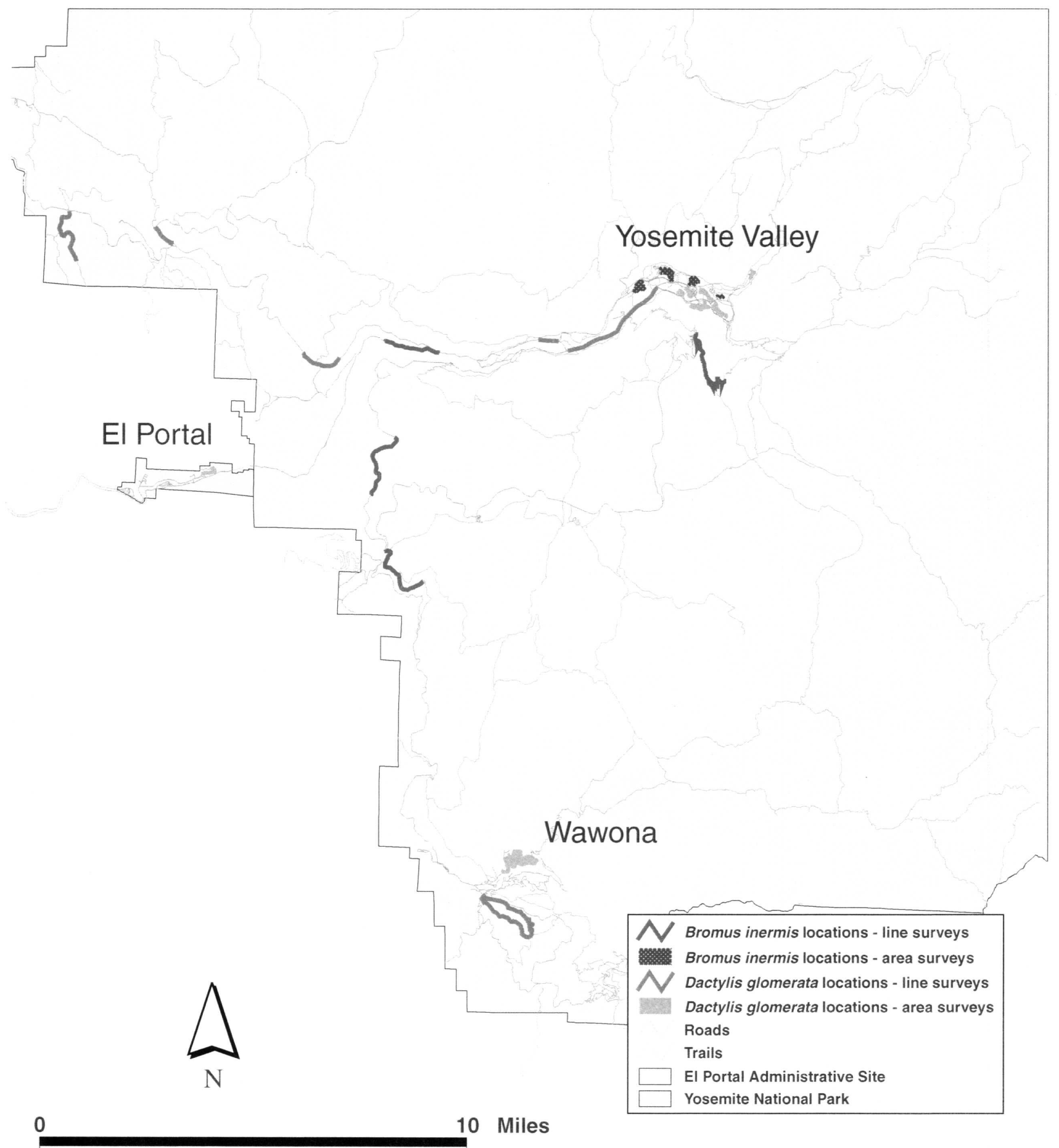

Map 26. Bromus inermis and Dactylis glomerata distributions based on alien plant surveys of disturbed areas in Yosemite National Park, 1998 and 1999. 


\section{Localized Wildland Priority \#2 Alien Grass Species - Map 1}

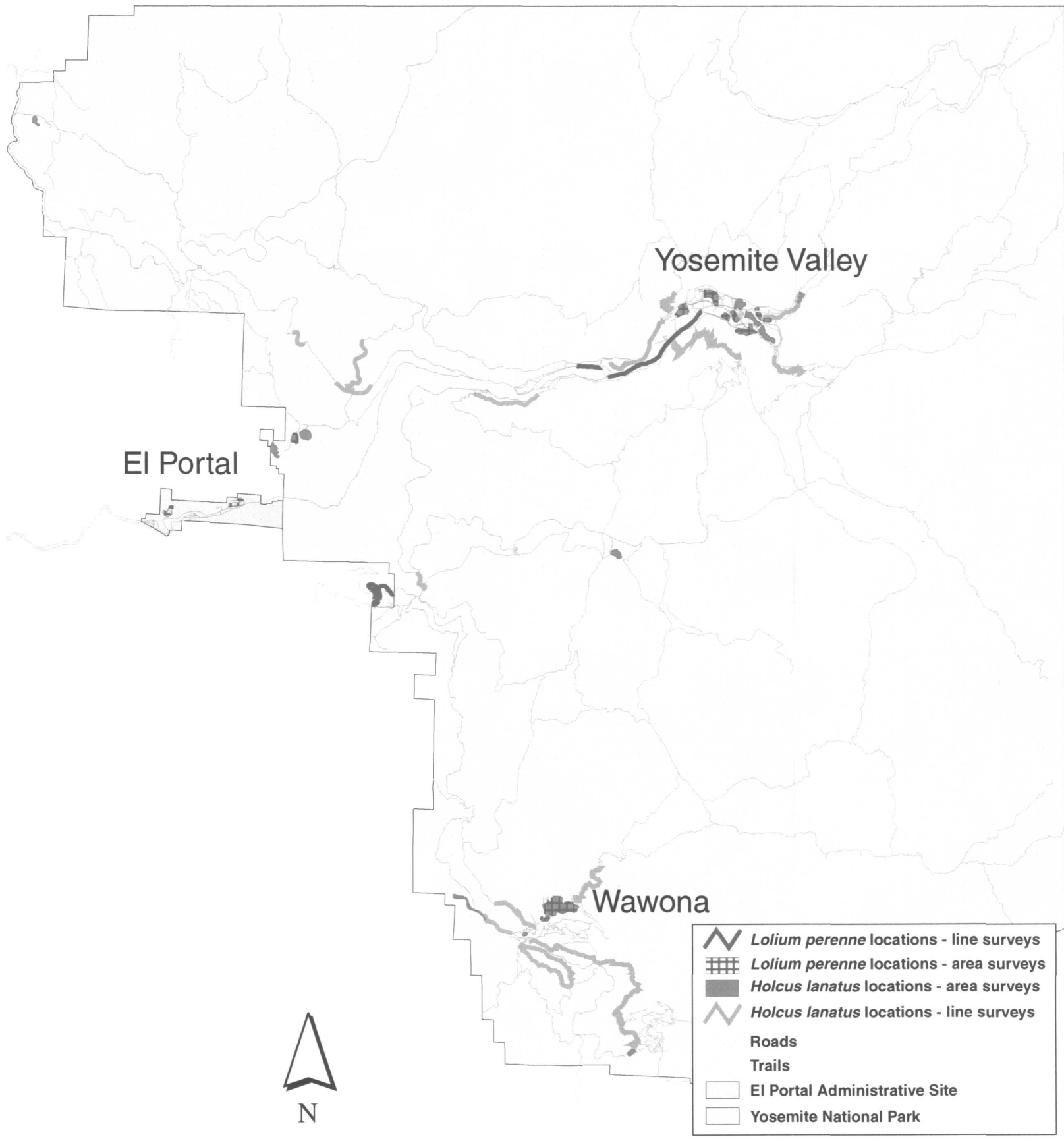

Map 27. Holcus lanatus and Lolium perenne distributions based on alien plant surveys of disturbed areas in Yosemite National Park, 1998 and 1999. 


\section{Localized Wildland Priority \#2 Alien Grass Species - Map 2}

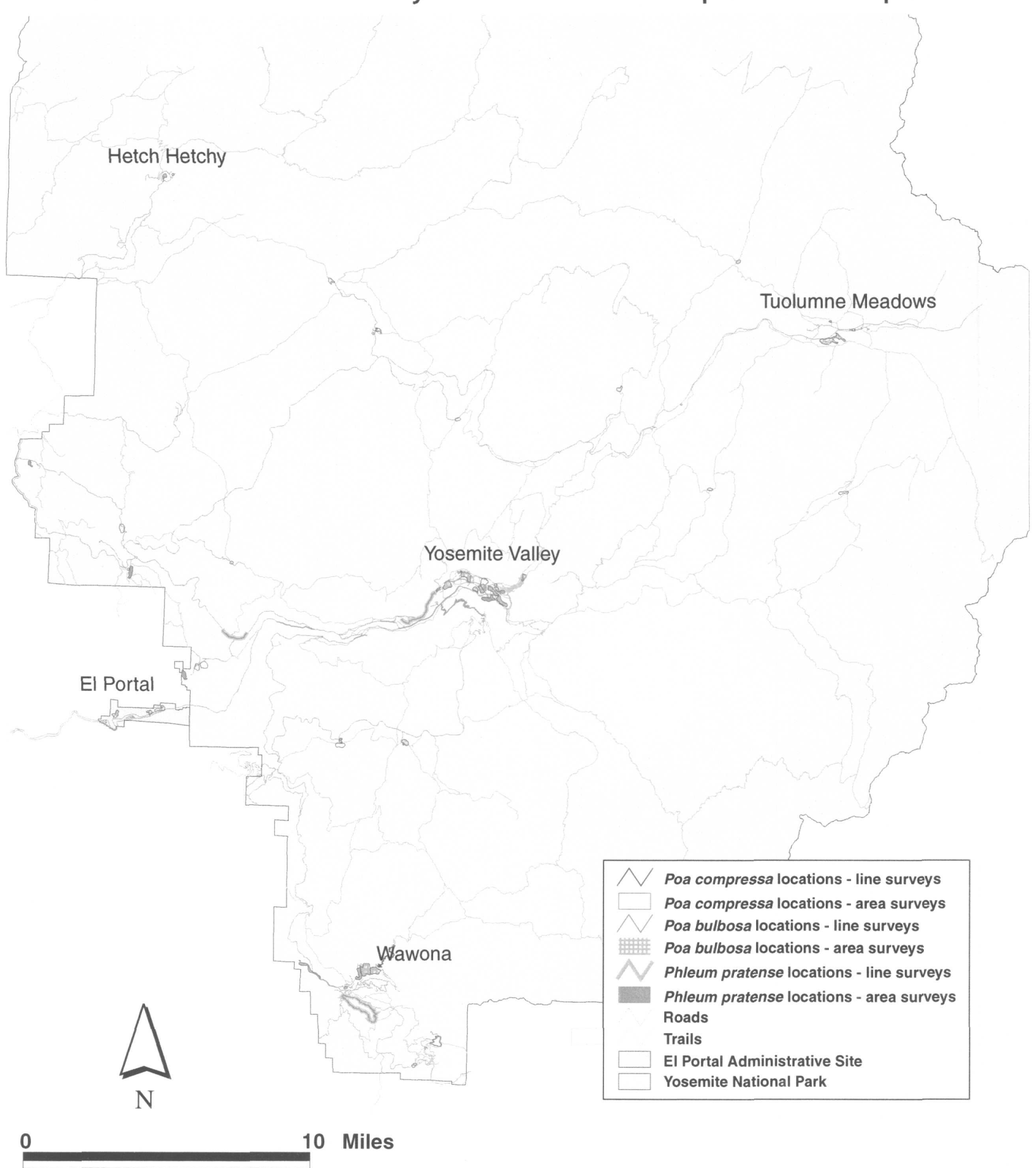

Map 28. Phleum pratense, Poa bulbosa, and Poa compressa distributions based on alien plant surveys of disturbed areas in Yosemite National Park, 1998 and 1999. 